Claremont Colleges

Scholarship@ Claremont

CGU Theses \& Dissertations

CGU Student Scholarship

2012

\title{
The Problem of Coming to Terms with the Past: A Post-Holocaust Theology of Remembrance
}

Jeremy D. Fackenthal

Claremont Graduate University

\section{Recommended Citation}

Fackenthal, Jeremy D., "The Problem of Coming to Terms with the Past: A Post-Holocaust Theology of Remembrance" (2012). CGU Theses \& Dissertations. Paper 33.

http://scholarship.claremont.edu/cgu_etd/33

DOI: $10.5642 /$ cguetd $/ 33$

This Open Access Dissertation is brought to you for free and open access by the CGU Student Scholarship at Scholarship @ Claremont. It has been accepted for inclusion in CGU Theses \& Dissertations by an authorized administrator of Scholarship @ Claremont. For more information, please contact scholarship@cuc.claremont.edu. 
The Problem of Coming to Terms with the Past:

A Post-Holocaust Theology of Remembrance

\author{
by \\ Jeremy D. Fackenthal
}

Claremont Graduate University

Spring 2012

(C) Copyright Jeremy D. Fackenthal, 2012

All rights reserved. 


\title{
APPROVAL OF THE REVIEW COMMITTEE
}

This dissertation has been duly read, reviewed, and critiqued by the Committee listed below, which hereby approves the manuscript of Jeremy D. Fackenthal as fulfilling the scope and quality requirements for meriting the degree of Ph.D. in Religion.

\author{
Dr. Roland Faber, Chair \\ Claremont Graduate University, Claremont Lincoln University \\ Kilsby Family/John B. Cobb, Jr. Professor of Process Studies \\ Dr. Philip Clayton \\ Claremont Graduate University, Claremont Lincoln University, \\ Claremont School of Theology \\ Vice President for Academic Affairs and Dean of Faculty \\ Dr. Oona Eisenstadt \\ Pomona College \\ Fred Krinsky Professor of Jewish Studies and Associate Professor of Religious Studies
}




\author{
Abstract \\ The Problem of Coming to Terms with the Past: \\ Toward a Theology of Remembrance \\ by \\ Jeremy D. Fackenthal \\ Claremont Graduate University: Spring 2012
}

This dissertation examines the problem of coming to terms with the past in post-World War II Germany in the wake of the Holocaust by examining the philosophical critiques of Theodor Adorno and Eric Voegelin. It then extends these critiques into the ongoing discussion of postHolocaust philosophy and theology, while introducing the speculative philosophy of Alfred North Whitehead as a helpful and appropriate means for continuing metaphysical reflection and perceiving the influence of the past upon the present and future in post-Holocaust discourse. This dissertation suggests, alongside Adorno and Voegelin, that finally coming to terms with the past proves much more dangerous than helpful. Instead, the focus should remain on remembering and reflecting critically upon the deleterious past of the Holocaust in order to avoid forgetfulness or effacement of the past. Whitehead's philosophy provides a metaphysical means for considering how the past remains with us in the present and into the future. Out of this injunction to remember comes a theology of remembrance, which draws heavily from Walter Benjamin's writing on weak messianism and inverse theology. The final focus of the dissertation is the development of a Christian theology of remembrance that requires Christians to rethink theology in light of the Holocaust. 


\section{Dedication}

In loving memory of Judy Goldblatt, who taught me to love life, to embody tikkun olam, and to strive after better possibilities for the world even in the face of hopelessness. 


\section{Acknowledgements}

I wish, first and foremost, to thank my wife and partner, Megan Fackenthal, for her love and support throughout my time as a graduate student. I am grateful for her encouragement, her advice, and her help as a sounding board for ideas. I would also like to thank my advisor and committee, Roland Faber, Philip Clayton, and Oona Eisenstadt, for their wisdom, their feedback, and their friendship through the writing process. I am particularly indebted to my advisor, Roland Faber, for his support of me and for the ways that he has helped to build and launch my academic career. Finally, I am deeply grateful to several friends who made this writing process so much more pleasurable than it otherwise would have been. To Tripp Fuller, thank you for the late night discussions and philosophical/theological arguments. To Tracy Hawkins, thank you for your own example of determination and high scholarship and for providing much needed moral support. To Kirsten Gerdes, thank you for our stimulating philosophical and ethical discussions and for your constant encouragement to seek out academic opportunities. 


\section{Contents}

Introduction 1

Vergangenheitsbewältigung and the Politics of Memory 8

$\begin{array}{lr}\text { Structure and Chapter Outline } & 15\end{array}$

$\begin{array}{ll}\text { Chapter 1: } & 18\end{array}$

Theodor Adorno and the Problem of Coming to Terms with the Past

$\begin{array}{ll}\text { Theodor Adorno: Philosopher and Critical Theorist } & 18\end{array}$

The Meaning of Working through the Past 20

$\begin{array}{ll}\text { Guilt and Consciousness } & 24\end{array}$

Democracy, Fascism, and German Politics $\quad 29$

$\begin{array}{ll}\text { Cultural and Individual Anti-Semitism } & 34\end{array}$

Adorno's Turn to the Subject as Working Upon the Past 39

Chapter 2:

Eric Voegelin's Critique of the Unmastered Past

The Political Philosophy of Eric Voegelin 44

The Cliché of the Unmastered Past 46

The Cliché of Collective Guilt $\quad 54$

Dedivinization, Dehumanization, and First and Second Reality 59

Master of the Present and Critical Self-Reflection 65

$\begin{array}{ll}\text { Chapter 3: } & 68\end{array}$

Metaphysics After Auschwitz

$\begin{array}{ll}\text { The Failure of the Enlightenment } & 69\end{array}$

Aristotle and the Logic of Form $\quad 73$

Metaphysical Reflection and Temporal Existence $\quad 77$

The Remains of Metaphysical Reflection $\quad 85$

Chapter 4:

94

Whitehead's Speculative Philosophy as Metaphysics in Fall

Whitehead as Mathematician and Philosopher 95

Speculative Philosophy as a System of General Ideas 99

$\begin{array}{lr}\text { Whitehead's Philosophical Method } & 108\end{array}$

Oscillation Between Experience and Abstraction 112

Chapter 5:

Whitehead and the Relation Among the Past, Present, and Future

$\begin{array}{ll}\text { The Non-linearity and Relativity of Past and Present } & 124\end{array}$

Creativity, Novelty, and the Potentiality of the Future 129

Tragedy and the Universality of Unique Events 137

Chapter 6:

152

Whitehead and God

The Dipolar God 154

Problematizing Whitehead's God 164

Whitehead's Relationship to Theology 174

Chapter 7: 
Theological Implications of Working Upon the Past and Mastering the

Present

Adorno's (Inverse) Theology 183

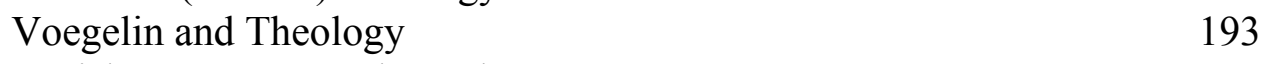

Jewish Responses to the Holocaust 200

Christian Theology After the Holocaust 211

$\begin{array}{ll}\text { Chapter 8: } & 217 \\ & \end{array}$

A Christian Theology of Remembrance

Volf's Theology of Remembrance $\quad 219$

Metz on Memory After Auschwitz 223

Benjamin's Weak Messianism and Inverse Theology 225

Remembrance of Damaged Life $\quad 239$

$\begin{array}{ll}\text { Bibliography } & 251\end{array}$ 


\section{Introduction: Vergangenheitsbewältigung and the Possibilities of Remembrance}

After the Second World War, as Europe sifted through the rubble of destroyed cities and towns and as survivors of Nazi concentration and extermination camps sought for a means to go on living, the German populace faced serious questions regarding the period from 1933 to 1945. Many in Germany referred to 1945 as $J a h r ~ N u l l,{ }^{1}$ demonstrating a strong desire to move forward with a clean slate, effectively forgetting the recent past of Nazi rule. However, as the next twenty years proved, the process of negotiating Germany's history and examining the relation between the past and present in German society and politics was not so simple as the phrase Jahr Null might denote. As Germans slowly began to admit, discuss, and examine the baleful events of the Second World War and the Holocaust, German intellectuals and public figures coined various terms for the process of recognizing and questioning the past, the most prominent of which became the term Vergangenheitsbewältigung. This word (or string of words) has been translated most often in English as "coming to terms with the past," though a more literal translation would be "mastering the past." Vergangenheitsbewältigung appeared in public use around the late 1950s and was accompanied by other terms, such as Aufarbeitung, "working through the past." The question of how to come to terms with the past occupied much conversation in German politics, media, and intellectual circles, and Vergangenheitsbewältigung "came to denote all discussions about the appropriate political, social, and moral agendas for the post fascist age and all initiatives designed to implement these alleged historical lessons."2 Moreover, Vergangenheitsbewältigung evolved into the means by which many Germans

\footnotetext{
${ }^{1}$ Stuart Parkes, Understanding Contemporary Germany (New York: Routledge, 1997), 148.

${ }^{2}$ Wulf Kansteiner, "Losing the War, Winning the Memory Battle: The Legacy of Nazism, World War II, and the Holocaust in the Federal Republic of Germany," in The Politics of Memory in Postwar Europe, ed. Richard Ned Lebow, et al. (Durham, NC: Duke University Press, 2006), 3.
} 
attempted to deal with their own guilt as a result of their direct or complicit involvement in the Final Solution, the term by which the Nazis referred to the systematic murder of approximately ten million people.

Though Vergangenheitsbewältigung may have originated as a worthwhile exercise in self-reflection, its critics (and I with them) note that it quickly devolved into a means of hastily dealing with the past so as to be done with and move on from the past. Indeed, the phrase "mastering the past" demonstrates that the process aims at its own sort of "final solution" as a point in time in which the past has been "mastered," a point at which the past can be set aside or simply swept under the rug. This understanding of Vergangenheitsbewältigung as a finite process with a clear end remains today and is exhibited in Wulf Kansteiner's essay 'Losing the War, Winning the Memory Battle.” Kansteiner writes quite positively and uncritically of Vergangenheitsbewältigung, suggesting:

the very origins of the term [Vergangenheitsbewältigung] marked the beginning of a new, self-conscious approach to the Nazi past and this turning point in the late 1950s was at least as important as the ultimate triumph of the paradigm of [Vergangenheitsbewältigung] during the 1980s, when West Germany's elite was most committed to historical self-education. ${ }^{3}$

As we shall see, this glowing appraisal of the process and any notion of an "ultimate triumph" were strongly criticized by both Theodor Adorno and Eric Voegelin in public lectures and radio addresses from the late 1950s to the mid-1960s. Additionally, questions of German guilt and of how to appropriate or consider the past arose again during what became known as the Historikerstreit of the 1990s and yet again in the early 2000s when Günter Grass and a coalition of German writers "made it their business to remember German victimization" during the Second World War. ${ }^{4}$ As this ongoing history demonstrates, the process of coming to terms with

\footnotetext{
${ }^{3}$ Ibid., 103.

${ }^{4}$ Ibid., 134.
} 
the past can hardly be considered complete, contrary to what Kansteiner maintains. Other German intellectuals, such as Günter $\operatorname{Kunert}^{5}$ (a poet, essayist, and short-story writer) remain in opposition to the very notion of mastering the past, viewing such mastery as permission to forget. Kunert, in his collection of essays entitled Auskunft für den Notfall, ${ }^{6}$ lends readers a depiction of history as a force that sneaks back into the present, even in the most unexpected of times: "die Geschichte kennt kein Verfallsdatum. Der einzelne vermag zu vergessen, die Geschichte vergisst nichts und holt unversehens unter der Decke des Alltäglichen die Vergangenheit hervor."7 Later in this essay on history and remembering, Kunert writes specifically of the phrase Vergangenheitsbewältigung, assessing it in the most critical of manners. "Es sind immer die gleichen Schwierigkeiten mit der Deutschen Vergangenheit, von der man, einer üblen Wortkonstruktion zufolge, meinte, man könne sie 'bewältigen.",8 Obviously, according to Kunert, the desire to "master" one's past goes unrealized precisely because the past always works its way into the present, even if unexpectedly or under the cover of the everyday. Thus, Kunert stands against those German writes that wish to dismiss both the past and the process of reflecting upon the past. Instead, he thoughtfully considers Germany's past while deconstructing the phrase Vergangenheitsbewältigung in order to point out its absurdity.

\footnotetext{
${ }^{5}$ Unfortunately, Kunert remains a little known German literary treasure. Born to a Jewish mother, he himself is considered Jewish, and as a result, he was unable to complete his education when the Nazis came to power. After the war, Kunert settled in East Germany and published his first collection of poetry in 1950. He became one of the few DDR writers to discuss the events that occurred under Nazi power, and consequently, he was not well favored by the DDR cultural attachés. Kunert eventually took a several year visa and relocated to the West, where he continues to live and write. Coincidentally, it was Kunert's short story "Fahrt mit der S-Bahn" that both opened up and complicated the notion of Vergangenheitsbewältigung for me as a young student of German literature and history.

6 "Information for the Emergency"

${ }^{7}$ Günter Kunert, "Gedenken und errinern," in Auskunft für den Notfall (München: Carl Hanser Verlag, 2008), 186. "History knows no expiration date. The singular ability to forget, history does not forget and gets out unexpectedly under the cover of the everyday."

${ }^{8}$ Ibid., 188. "It's always the same difficulty with the German past, which one, according to a bad word construction, thinks one could 'master."'
} 
The following chapters will critically examine the process of Vergangenheitsbewältigung, using it as a paradigm to question whether it is possible to come to terms with harmful, deleterious aspects of the past, and what "coming to terms with the past" would mean for the present and future. If finally coming to terms with the past proves potentially more harmful, as I will suggest, then we must inquire as to how we can conceive a way to reflect upon and remember the negative content of the past while also realizing different possibilities for the future such that the deleterious pieces of the past are not (purposefully or passively) repeated. To be clear, the harmful past considered here are the events of the Holocaust, the systematic murder of ten million people in the Nazi death camps of Eastern Europe. I comfortably label this a post-Holocaust work because it evaluates and deconstructs philosophical and theological principles in light of the horrifying events of the Holocaust.

In the context of post-World War II Germany, both Theodor Adorno and Eric Voegelin provide strong critiques of the very possibility of coming to terms with the past and address the problems that finally working through or "mastering" one's past might invite. I will examine these critiques and warnings in depth before turning to the philosophical work of Alfred North Whitehead in order to recast an understanding of how the past comes to bear upon the present and future. In Whitehead's process metaphysics the entirety of the past remains always as objective content to be taken into account by future occasions, yet the past is not determinative of the future, as the inherence of novelty and the possibility of the future also play into the unfolding of subsequent events. By bringing together the work of Adorno, Voegelin, and Whitehead, I conceive of a means of retaining the deleterious content of the past-in this regard, the very rupture of civilization and history—resisting the desire to gloss over what is painful 
about the past, while understanding that the future must take seriously the emotional depth of the past and the abhorrent reality of the past as we seek to appropriate a norm of remembrance.

I come to this assessment of the correspondence among the past, present and future with a particular interest in Jewish-Christian relations and post-Holocaust theology, recognizing both the need to address Christianity's all-too-often deleterious relationship with Judaism as well as the need to resist forgetting the history of this relationship and the long stream of anti-Semitism leading up to the Holocaust. The Christian tradition's long history of anti-Judaism has been well documented by a number of Christian and Jewish historians. ${ }^{9}$ Additionally, the complicity of some Christians with Nazi authorities and Holocaust perpetrators has received much focus in the past few decades. ${ }^{10}$ My contention is that Christians today must address this painful portion of our past, lest we be too quick to move toward forgetfulness. This history and this need for remembrance provides the background content from which I come to this topic and the theological/ethical pole toward which my project moves.

Ultimately, engaging this topic from a theological perspective requires that one begin to unfold a Christian theology of remembrance that considers and takes seriously the painful and debilitating events of the Holocaust and that recognizes what Adorno considers the end of metaphysics as usual, and therefore also the end of the metaphysically based onto-theology. Jewish thinkers have already dealt extensively with this problem, proposing various religious options after the Holocaust, some of which will be examined in chapter seven. ${ }^{11}$ Now the burden must be laid upon Christianity — it must deal seriously with the Holocaust as a rupture within the history of Christian theology. This dissertation will propose one possibility for how such a

\footnotetext{
${ }^{9}$ Most notably, Edward Flannery's The Anguish of the Jews.

${ }^{10}$ See Susannah Heschel and Robert P. Eriksen's Betrayal: German Churches and the Holocaust, and Ernst Klee's Persilscheine und falsche Pässe: wie die Kirchen den Nazis halfen.

${ }^{11}$ See particularly Emil Fackenheim's To Mend the World and God's Presence in History, and Emmanuel Levinas's "Useless Suffering."
} 
Christian theology might look and will examine what it might contribute to the ever-flowing current of post-Holocaust theology and Jewish-Christian dialogue. ${ }^{12}$ In this final section, I will draw upon the theological motifs emerging from Adorno, Voegelin, and Whitehead, the theologies of Roland Faber in his God as Poet of the World and Bernard Loomer in his "The Size of God", as well as writings of Walter Benjamin (while also including influences from other Jewish and Christian responses to the Holocaust, such as those offered by Emil Fackenheim, Emmanuel Levinas, Clark Williamson, and Johann Baptist Metz) as I seek to form a theology of remembrance. I must note that this theology remains a Christian theological project, and it manifests itself as one that is self-critical of Christian theology.

As I delve into the question of coming to terms with the past, I am aware of a number of problems, issues, or existing criticisms that this project must consider. First, in this dissertation I will use post-war Germany as a paradigm for reflecting on the problems of coming to terms with one's past because of the centrality of this theme in post-World War II critical and political theory, literature, and public discourse in Germany. Indeed, as Voegelin notes, the term Vergangenheitsbewältigung became something of a cliché, requiring serious engagement and critique. Voegelin, Adorno, Habermas and others sought to deconstruct this term in order to recast post-War Germany's future under a rubric of remembrance and watchfulness. However, while using this paradigm, I am aware of the distinctiveness of the German context in which the term came into use and do not seek to sever it from this context in order to re-appropriate it in the potentially foreign setting of this work. Rather, understanding the issue of Vergangenheitsbewältigung within the German context brings to light the full weight of the emotional content of the post-Holocaust period out of which this work comes to life. Germans

\footnotetext{
${ }^{12}$ Most notably for this project: the post-Holocaust theologies of Richard Rubenstein, Eliezer Berkovitz, and Emil Fackenheim, Clark Williamson, and Johann Baptist Metz.
} 
sought (and still seek) a means to address their feelings of shame and guilt after the Holocaust. ${ }^{13}$ In fact, the problem of coming to terms with the past is the problem of addressing the extreme suffering of the victims as well as the guilt and shame of the perpetrators. This emotional content serves as the concrete experience of the past about which I write. Furthermore, this work remains conscious of the problem with using the Holocaust as an "example," as an event to be considered, dissected, and discussed. In contrast (and emphatic opposition to) this deployment of the Holocaust as an event, alongside Adorno, this work views the Shoah as the paradigmatic event(s) of the $20^{\text {th }}$ century, after which philosophical and theological reflection must change. Secondly, when discussing Christianity's role in and response to the Holocaust, I recognize the stark distinction between the need for remembrance and the need for apology. Apology can rightfully be seen as an attempt to let off the hook those who continue in their (sometimes more) subtle ways of oppression, whereas remembrance keeps a watchful eye on the future, helping to ensure that abominations of the past are not repeated. ${ }^{14}$ The constructive work of this dissertation, therefore, will not focus on apology and forgiveness, but on the need for memory (for a theology of remembrance) and for historical reflections that do not seek to gloss over the harmful events of the past. Thirdly, Adorno offers a strong warning against the continuation of "metaphysics as usual" after the Holocaust. In fact, more forcefully stated, Adorno writes that metaphysics after Auschwitz has become paralyzed—speculative metaphysics simply cannot respond to the actual events of the Holocaust. ${ }^{15}$ As I appropriate the metaphysical work of Whitehead, it will become necessary to explore Adorno's critiques and evaluate Whitehead's

\footnotetext{
${ }^{13}$ The recurrence of these issues within Germany can be seen in the Goldhagen Debate (the German reception of Daniel Goldhagen's Hitler's Willing Executioners and the subsequent debate contesting its major thesis) and the Historikerstreit of the late 1980 s and early 2000 s.

${ }^{14}$ For an extended examination of the "trend" of apology in the late $20^{\text {th }}$ and early $21^{\text {st }}$ centuries, see Gad Horowitz, "Global Pardon: Pax Romana, Pax Americana, and Kol Nidre" (December 2001)

$<$ http://bad.server.org/issues/2001/58/horowitz.html $>$.

${ }^{15}$ Theodore Adorno, Negative Dialectics, trans. E. B. Ashton (New York: Continuum, 1973), 362.
} 
metaphysical work on the basis of these critiques. Ultimately, Adorno deems metaphysical reflection in some form possible after Auschwitz, and it will be my goal to demonstrate Whitehead's system as one possible way in which to engage in metaphysical reflection in a postHolocaust context.

\section{Vergangenheitsbewältigung and the Politics of Memory}

As I stated at the outset of this introduction, Germany has thought extensively about the process of coming to terms with the past, and various writers, intellectuals and public figures within Germany have viewed this process in various ways, some of them more helpful than others. Discussions regarding how best to interpret and remember Germany's Nazi past have come to a head at different times over the last sixty years. Below I will provide further reflection on the situation in Germany regarding Vergangenheitsbewältigung and will discuss the more recent exchange relating to National Socialist history, which has been termed the Historikerstreit.

In his edited volume on the politics of memory, Richard Lebow writes: "An understanding of the past not only helps us interpret the present; it tells us who we are. Shared experiences and memories, and the values and commitments they create and sustain, provide distinctive identities to individuals and communities."16 Nebow and the other editors of Politics of Memory in Postwar Europe maintain that politics infuses the construction of memory, and particularly national or collective memory. ${ }^{17}$ However, their book focuses primarily on how memories generate certain policies that subsequently aid in shaping a (new) national identity, or how robust national identities might be necessary in order for people to be more inclined to examine the past. I cite this volume because it seems to provide evidence of a strong trend in

\footnotetext{
${ }^{16}$ Richard Ned Lebow, "The Memory of Politics in Postwar Europe," in The Politics of Memory in Postwar Europe, ed. Richard Ned Lebow, et al. (Durham, NC: Duke University Press, 2006), 3.

${ }^{17}$ Ibid., 4.
} 
political science and public policy: if memory of harmful events shapes policy, then the requirement for memory has passed; if we memorialize our failures as well as our triumphs, then the memorials remember for us, enabling us to go about forgetting the past. As I will demonstrate in the coming pages (particularly through Voegelin, who would be highly critical of recourse to mere policy changes), I find solutions to the problem of coming to terms with the past stemming from either public policy or memorialization to be far too simplistic and naïve with regards to the way in which memory operates in individuals. If setting policy or building memorials to our past could solve the problem of how we relate to the past, then more recent issues such as the Historikerstreit or Iran's public denial of the events of the Holocaust would not be problems (because they would not exist). In his own work on the efficacy of Holocaust memorials, James Young argues that we all-too-often construct memorials in order to encapsulate our public or individual conscious memories such that we no longer feel the requirement to remember the past ourselves. Memorials then in essence let us off the hook; we don't have to remember the harmful events of the past because a monument, building, or statue remembers for us. ${ }^{18}$ The same argument could be made in terms of public policy. If public policies are in place to ensure that the past does not recur, then the requirement of memory has been lifted; we no longer need to remember the deleterious past because our policies already ensure that the past will not be - cannot be-repeated. The fact that Lebow and the others included in his volume profess these views means that they are views with which (or against which) this work must argue. As I hope is becoming clear, I will suggest that remembrance of the destructive events of the Holocaust plays a vital role in ensuring that the future proves less

\footnotetext{
${ }^{18}$ James E. Young, The Texture of Memory: Holocaust Memorials and Meaning (New Haven, CT: Yale University Press, 1993), 5.
} 
deadly, less horrific, and less oppressive. Neither public policy nor memories can serve as appropriate substitutes for remembrance.

Jane Kramer, in agreement with the quote from Lebow above (but perhaps with a more realistic perspective), writes of post-war (and cold war) Germany as having buried its past and particularly its Nazi past, without having first engaged its past or allowed the past to become a part of its history. After reunification when Germany was finally able to deal with its "pre-wall" past, Germans "discovered that it was hard to be ordinary folks —ordinary European folkswhen you had a Holocaust in your history."19 Johann Baptist Metz describes the situation in post-reunification Germany as follows:

It may be that everything comes down to this: It is precisely because of unification that we are confronted once again with our recent history, that we will all together be drawn anew into history, a postwar history in which the memory of Auschwitz was too often repressed in the West, while in the East it was, at best, ideologically functionalized. ${ }^{20}$

This period in the early 1990s in which Germans (together as unified Germans) could resume discussion of their Nazi past is the period in which deep disagreement over Germany's and Germans' roles in the past came to a head. The disagreement became known as the Historikerstreit, and it is demonstrative of Germany's ongoing anxiety regarding the relation of the past and the present. This Streit or argument began with a series of articles published in the Frankfurter Allgemeine Zeitung, beginning with an article by Michael Stürmer on 27 December 1993. Jürgen Habermas, Adorno's student and the most prominent remaining critical theorist of the Frankfurt School, describes Stürmer's statements in his own essay, "Can We Learn from History?" He quotes a question Stürmer posed in his article: "Confronted by an increasing lack of grounding, however, we must ask how long the petrified guest from the past should be

\footnotetext{
${ }^{19}$ Jane Kramer, The Politics of Memory: Looking for Germany in the New Germany (New York: Random House, 1996), xvi.

${ }^{20}$ Johann Baptist Metz, "The Church After Auschwitz," in A Passion for God: the Mystical-Political Dimension of Christianity, ed. and trans. J. Matthew Ashley (New York: Paulist Press, 1998), 128.
} 
permitted to veto civic virtue and love of the fatherland, both in the future and in the past?"21 Habermas interprets Stürmer's question as implying that "in order to become a normal nation, we should avoid self-critically recalling Auschwitz., ${ }^{22}$

Habermas's essay, as the title suggests, questions whether or not we can learn from history or from events within history, whether positive or negative. Refusing to settle on any specific response, he suggests that there is no satisfying theoretical answer to the question. Yet he does provide statements regarding what we ought not to do with history: "Historicism is clearly always in danger of granting to a past that has been locked up in a museum, and aesthetically shaped, a crippling dominance over a present condemned to passivity." ${ }^{23} \mathrm{We}$ should not appeal to the historicists' reading of history, nor must we attempt to efface the negative aspects of the past because of our discomfort with them. "In order to learn from history, we must not allow ourselves to push unsolved problems aside or repress them; we must remain open to critical experiences - otherwise we will not even perceive historical events as counterevidence, as proofs of shattered expectations." ${ }^{24}$ The Historikerstreit provided evidence for both of these concerns-historicism and forgetfulness.

To a large extent, the Historikerstreit begins with questions of German guilt regarding the Holocaust. In The Unmasterable Past, Charles Maier suggests "insofar as a collection of people wishes to claim existence as a society or nation, it must thereby accept existence as a community through time, hence must acknowledge that acts committed by earlier agents still bind or burden the contemporary community." There is no point at which responsibility for past wrongs goes

\footnotetext{
${ }^{21}$ Michael Stürmer, quoted in Jürgen Habermas, "Can We Learn from History?” in A Berlin Republic: Writings on Germany, trans. Steven Rendall (Lincoln, NE: University of Nebraska Press, 1997), 5.

${ }^{22}$ Jürgen Habermas, "Can We Learn from History?" in A Berlin Republic: Writings on Germany, trans. Steven Rendall (Lincoln, NE: University of Nebraska Press, 1997), 5.

${ }^{23}$ Ibid., 8.

${ }^{24}$ Ibid., 13.
} 
away. ${ }^{25}$ However, some German historians thought that there might in fact be a point at which memory of responsibility does go away. Hans Mommsen, a left-wing German historian ${ }^{26}$, points out two historiographic agendas following the Second World War: one that would deal with the past successively until it would disappear without a trace, and another that sought to place the past within the stream of German history. ${ }^{27}$ These two approaches can be summarized as "comparison" and "normalization," respectively, and in the 1980s the two approaches collided, causing a very public exchange of ideas in the Frankfurter Allgemeine Zeitung, preceding the exchange between Stürmer and Habermas. Ernst Nolte, a German historian and strong conservative, is another figure associated with the Historikerstreit who aligned himself with the comparison approach, which is itself wedded to more conservative political views. Conversely, Hans Mommsen (and perhaps Habermas) aligned himself with the normalization approach. Nolte, who used the Hegelian dialectic and Heideggerian metaphysics in his own philosophical work, ${ }^{28}$ attempted to argue that the fascist movement in Germany had been a reaction to the leftwing Hegelianism that engendered Marxist thought and historical materialist tendencies in German intellectuals. ${ }^{29}$ As a result, he viewed fascism as using the same philosophical methods to uncover alternative conclusions. Moreover, Nolte argued for fellow historians to recognize "that every major nation with claims to power (the United States and Britain excepted) has had 'its own Hitler era, with its monstrosities and sacrifices." ${ }^{30}$ Nolte wrote an essay in 1986 in the Frankfurter Allgemeine Zeitung entitled "Vergangenheit, die nicht vergehen will" (The past that will not pass away) in which he publically unfolded and explicated these views as well as his

\footnotetext{
${ }^{25}$ Charles Maier, The Unmasterable Past: History, Holocaust, and German National Identity (Cambridge, MA: Harvard University Press, 1988), 15.

${ }^{26}$ Mommsen is also a functionalist in the functionalist/intentionalist debate regarding German's ultimate turn to the "Final Solution."

${ }^{27}$ Ibid., 16-17.

${ }^{28}$ Ibid., 26.

${ }^{29}$ Coincidentally (or not), many of these intellectuals with Marxist leanings were also Jews.

${ }^{30}$ Ibid., 28.
} 
contention that Germany should no longer allow its Nazi past to draw attention away from what he viewed as more pressing issues. Habermas subsequently issued a strong critique of this article in Die Zeit, to which Nolte then responded, accusing Habermas of various personal attacks against him and suggesting that Habermas's leftist interpretation of $20^{\text {th }}$ century history should not be permitted as the decisive or lasting interpretation. ${ }^{31}$

The question of historical interpretation and national identity re-emerged later in the 1990s with the controversy between Stürmer and Habermas. Stürmer thought Germans needed a readily available historical identity, whereas Habermas saw his search for a historical identity as "providing a unifying thread for the revisionist assessments of the Third Reich offered by Nolte ...History for Sturmer, Habermas wrote, amounted to a sort of spiritual insurance payment to compensate modern man for the damages entailed by modernization."32 Habermas saw Stürmer's views as tending toward the resurrection of nationalism and an anticommunist reaction. Habermas writes: "I do not want to ascribe evil intentions to anyone. But there is a simple criterion that sorts out the two attitudes. Some of us assume that the work of gaining distance and understanding liberates the power of reflective memory, thus enlarging our capacity to work out ambivalent legacies on our own. But others want to use a revisionist narrative to equip a conventional identity with a national history."33 Habermas may well have viewed recourse to nationalism as progressing down the same dangerous path that the nationalism of the mid-1930s had ultimately led. In any event, Habermas, following his teacher Theodor Adorno, argued fervently for critical self-reflection regarding the past and stood very much against the tendency toward revisionist narratives.

\footnotetext{
${ }^{31}$ Ibid., 32.

32 Ibid., 44.

${ }^{33}$ Ibid., 47.
} 
What the two approaches to the Historikerstreit demonstrate are, first, a fundamental disagreement on whether the Holocaust was a unique event that cannot be compared (with its singularity intact) or whether it was unique as a historical phenomena but ultimately comparable to other atrocities of the twentieth century. Depending on which approach one adopts signals whether or not one can make claims like Nolte's that the definitive event of the $20^{\text {th }}$ century was in fact the Russian "fall" to communism and not the events of Nazi Germany. Second, the two approaches illustrated by the Historikerstreit leave historians, philosophers, and theologians with two primary means for assessing and perceiving the past: by means of historicism or by means of philosophical historical analyses that reject attempts at seeking long historical arches in which final causes and effects might be found. The philosophers and theologians cited in this work find themselves in the latter position. Nolte, however, contends that the past can be mastered by historicizing it, by endowing the past with historical and philosophical perspective. Nolte writes: "there is nothing human that stands outside history. For this very reason it must be thoroughly understandable. What is not understandable would exist as an 'absolute evil' or an 'absolute good' outside history and could not be a matter for the historian." ${ }^{34}$ The fundamental suppositions of this dissertation reject the idea that any mastery of the past is possible —and if it were possible, it certainly wouldn't be helpful. In the subsequent chapters I will unfold a philosophy and theology that views the Holocaust as a paradigmatic series of events after which both philosophical and theological reflection must change, and I will argue for a form of history that resists historicizing modes by employing the speculative philosophy of Whitehead as a form of metaphysics based on occasions of experience rather than overarching narratives.

\footnotetext{
${ }^{34}$ Ernst Nolte, "Die Ausschau nach dem Ganzen" in Der europäische Bürgerkrieg. Nationalsozialismus und Bolschewismus (Frankfurt am Main: Propyläen, 1987), 25-26. Quoted in Maier, The Unmasterable Past, 66.
} 
As stated above, I intend to use the German situation and critical reflection on Vergangenheitsbewältigung as an initial paradigm through which to enter a larger discussion about how to treat harmful aspects of the past, and particularly the past related to the events of the Holocaust. As a result, after the first two chapters, my analysis will move away from the particularity of the German situation in order to address the problem of coming to terms with the past in the larger Western philosophical and religious traditions. Nevertheless, understanding the German problem of Vergangenheitsbewältigung helps, I believe, to show both positive and negative examples of how best to appropriate and examine the past.

\section{Structure and Chapter Outline}

In the first chapter, I will address Adorno's critiques of the idea of "coming to terms with the past," or "working through the past," which arises through his own historical materialist conception of the world and his critiques of reification. The political philosopher Eric Voegelin likewise critiques the idea of a Vergangenheitsbewältigung, or a "mastering of the past," as I will discuss in the second chapter, though he does so with a nuance that will prove helpful in later chapters regarding his appeal to transcendence as grounding the ethical mandate to master the present. The third chapter of this dissertation will focus on Adorno's critique of traditional metaphysics in a post-Holocaust society and will serve as a bridge between the critical work of Adorno and Voegelin and the philosophical (and metaphysical) offerings of Whitehead.

The second part of this dissertation will turn toward the speculative philosophy of Whitehead in an effort to explicate a means for understanding the relation of the past to the present and future. In the fourth chapter I will have the task of demonstrating that Whitehead's self-critical and revisable system does indeed provide a promising alternative in the face of Adorno's critiques of metaphysics. Bringing Whitehead into dialogue with Adorno's critique 
will also inherently provide a basic framework for understanding my appropriation of Whitehead's work as it pertains to an examination of the unique, deleterious events of the past. I will argue that Whitehead's system is promising in spite of Adorno's criticism because it remains a system in process that seeks to account for every drop of experience without subsuming all experience under a fixed system of positive meaning. Chapter five will turn more explicitly toward a reexamination of the uniqueness of past events within Whitehead's metaphysics. The sixth chapter will deal with Whitehead's vision of God.

The final section of this dissertation will consist of my own constructive theology emerging from the work of Adorno, Voegelin, and Whitehead. In the seventh chapter, I will assess the theological implications of Adorno and Voegelin, while also taking into account the wider field of post-Holocaust theology. My goal in the final chapter will be to draw together these theological warnings, prohibitions and insights from Adorno and Voegelin with the theological inclinations emerging from Whitehead's process philosophy in order to develop a Christian theology of remembrance. In this final chapter I will examine Miroslav Volf's theology of remembrance as well as Walter Benjamin's discussion of remembrance as redemption in his "Theses on the Philosophy of History." Ultimately I find my own theology aligned more closely to Benjamin's because it provides a robust historical materialist conception of redemption of the past and affirms my aversion to seeking an escape from material reality by appealing entirely to transcendence. What this project will point out, through the chapters on Adorno's critique of metaphysics, through Whitehead's avoidance of the fallacy of misplaced concreteness, through the post-Holocaust theologians examined in chapter seven, and, finally, through Benjamin's form of inverse theology, is that betraying damaged life (as Adorno terms it) results in a betrayal of those who have suffered at the hands of the Nazis, a betrayal of those who 
continue to suffer under oppressive conditions in whatever system falls into the political pitfalls highlighted by Voegelin (as we shall see in chapter two), and a betrayal of the present and future of this world by relieving us of the task of remembrance. As I weave together the insights gleaned from Benjamin in the last chapter, I return to Whiteheadian metaphysics in order to explore a conception of God in line with Whitehead's description of God in Process and Reality, but I now do so as a starkly materialist theologian in terms of my desire to focus on damaged life in an effort to remember the suffering of the Holocaust without overcoming, mastering or integrating this suffering. 


\section{Chapter One: Theodor Adorno and the Problem of Coming to Terms with the Past}

As late as the 1960s, the Holocaust and the events surrounding this historical rupture remained quite raw subjects within the German consciousness - subjects that many wished not to discuss, or worse, wished to completely efface. In the late 1950s and early 1960s, Theodor Adorno began writing and lecturing on philosophical and psychological responses to the Holocaust, including responses that addressed the prevailing notion that Germans must come to terms with or master their Nazi past. This chapter examines Adorno's critique of the possibility for mastering or finally coming to terms with the past, and it highlights what he sees as the more helpful concept of "working upon" the past. His thoughts related to the problem of coming to terms with the past appear most prevalently in two essays, "The Meaning of Working Through the Past" and "Education after Auschwitz." I begin with Adorno in order to clearly articulate the problem of effacing the past and to introduce aspects of historical materialism that ultimately prove vital to this project.

\section{Theodor W. Adorno: Philosopher and Critical Theorist}

Theodor Wiesengrund Adorno, born in Frankfurt am Main in 1903 to a Roman Catholic mother and Jewish father, became over the course of his academic career one of the more famous philosophers and sociocultural critics to be associated with the Frankfurt School, the pioneering force in critical theory. Trained in both philosophy and musical composition, Adorno's combination of aesthetic and cultural critiques with a historical materialist approach mirrored the interdisciplinary methods of the Institut für Sozialforschung (Institute for Social Research) housed at the University of Frankfurt, of which Adorno became a member in 1938. Walter Benjamin, a long-time friend of Adorno who was himself loosely affiliated with the Institute, 
once wrote that the members all believed "that the teaching about society can only be developed in the most tightly integrated connection of disciplines; above all, economics, psychology, history and philosophy," a belief which Adorno demonstrates throughout his many writings. ${ }^{1}$

In 1933, when the National Socialist party rose to power, Adorno lost his position at the University of Frankfurt as a result of his Jewish background. He spent a brief time in Oxford, England, before accepting a position offered to him by Max Horkheimer, director of the Institute for Social Research, which had already been relocated to Columbia University in New York. During his time in the United States, Adorno worked with Institute members on the lengthy social-psychological work The Authoritarian Personality and wrote, with Horkheimer, Dialectic of Enlightenment. Finally, in 1949, Adorno resumed his teaching post at the University of Frankfurt; and, shortly thereafter, the Institute for Social Research returned to Frankfurt as well. It was in this period from 1949 to the end of his life in 1969 that Adorno was most prolific, writing on a myriad of subjects, including literature, music, social theory and philosophy. Most significant for this dissertation are his "Lectures on Metaphysics," given at Frankfurt in the summer of 1965, Negative Dialectics published in 1966, and the two essays mentioned above, “The Meaning of Working through the Past" and "Education after Auschwitz," originally given as lectures in 1959 and 1968 respectively.

Adorno struggled with the fact of his absence during the period of National Socialism, and he expresses a great deal of survivor's guilt in the latter pages of Negative Dialectics. Upon his return to Germany he found a climate in which the recent events of the Nazi Third Reich and the Holocaust were viewed as dark marks that simply needed to be rubbed out or painted over in order for Germans to effectively proceed with their new democracy in an increasingly globalized

\footnotetext{
${ }^{1}$ Walter Benjamin, "Ein deutsches Institut freier Forschung" in Gesammelte Schriften, vol. 3 (Frankfurt: Suhrkamp, 1972). Quoted in Brian O'Connor, Introduction to The Adorno Reader, ed. Brian O'Connor (Malden, MA: Blackwell Publishers, 2000), 7.
} 
world economy. As this chapter will note, Adorno's views on the past and the question of the "unmastered past" clashed with the majority view of public intellectuals and politicians in the new Federal Republic. He wrote around 1950 that "reminding people of Auschwitz was held to be the expression of a tedious resentment,"2 a resentment which he later addressed more directly in "The Meaning of Working through the Past." Adorno's relationship to the German populace remained tenuous throughout the rest of his life. While Rolf Tiedemann notes that Adorno and Horkheimer, after returning to Germany, attempted to move their theoretical insights on antiSemitism outlined in Dialectic of Enlightenment into a more practical application, Adorno was constantly critiqued as a lover of theory who had little use for practice. When the Student Movement of the 1960s took shape, students reacted negatively to Adorno and reportedly attempted several times to interrupt his classes. Such views, which may indeed have been unwarranted, cast a pall over the last few years of his life. Contrary to these views, Adorno in fact describes in Negative Dialectics a "new categorical imperative" calling for people to "arrange their thoughts and actions in such a way that Auschwitz should never be repeated, that nothing of the sort should ever happen again." ${ }^{3}$ He further demonstrates a sort of bridge building between psychoanalytic and Marxist theory and the implementation of a practice that would attempt to root out the causes of anti-Semitism in the writings explored in this chapter.

\section{The Meaning of Working though the Past}

In "The Meaning of Working through the Past," (titled in German "Was bedeutet: Aufarbeitung der Vergangenheit"), Adorno applies cultural, political, and psychological critiques to the German situation in which he was writing. Addressing the post-World War II milieu,

\footnotetext{
${ }^{2}$ Theodor W. Adorno, Gesammelte Schriften, ed. Rolf Tiedemann (Frankfurt am Main: Suhrkamp, 1970-1986), 10.1:53. Quoted in Rolf Tiedemann, Introduction to Can One Live after Auschwitz: A Philosophical Reader (Stanford, CA: Stanford University Press, 2003), xii.

${ }^{3}$ Theodor W. Adorno, Negative Dialectics (New York: Continuum, 1973), 365.
} 
Adorno raises questions of collective guilt, the effacement of memory, and the survival of National Socialist tendencies within the new German democracy. It is here also that he introduces the notion of a turn or return to the subject, a phrase that he later reprises in "Education After Auschwitz" and his "Lectures on Metaphysics."

Adorno begins by noting that the phrase "working through the past" had become a "modish slogan" of which one should be highly suspicious. ${ }^{4}$ He comments on how the term had come to be understood in popular German rhetoric, writing: "In this usage 'working through the past' does not mean seriously working upon the past, that is, through a lucid consciousness breaking its power to fascinate. On the contrary, its intention is to close the books on the past and, if possible, even remove it from memory." German Social Council for Coordinating Collaborative Work between Christians and Jews in 1959, does not use the term Vergangenheitsbewältigung; however, it is clear that this sense of "mastering" the past remains the very notion he critiques, and as the introduction demonstrated, these two words are tied together both historically and conceptually. Adorno himself employs the words Aufarbeitung and Verarbeitung as he describes and critically assesses the process of working through or coming to terms with the past. Henry Pickford translates these words as "working through" and "working upon," respectively. I will adopt Pickford's translation for use in this work for the sake of clarity; however, I think it important to note Pickford's own discussion of these words found in the notes to the English translation of "The Meaning of Working through the Past." He explicates the difference between Aufarbeitung and Verarbeitung as follows: "[Aufarbeitung's] common meaning is that of working through in the sense of dispatching tasks that have built up and demand attention, catching up on accumulated

\footnotetext{
${ }^{4}$ Theodor Adorno, "The Meaning of Working through the Past" in Can One Live After Auschwitz, ed. Rolf Tiedemann and trans. by Henry W. Pickford (Stanford, CA: Stanford University Press, 2003), 3.

${ }^{5}$ Ibid.
} 
paperwork, etc." ${ }^{6}$ Pickford goes on to articulate the meaning of Aufarbeitung as giving the impression of working through an "unpleasant obligation, clearing one's desk," and he ties it to the term Vergangenheitsbewältigung, writing that some with less sensitivity than Adorno began using the word Aufarbeitung interchangeably with Vergangenheitsbewältigung. ${ }^{7}$ Verarbeitung, on the other hand, conveys a sense of processing, digesting, or assimilating (as coming to fully understand). In some uses of Verarbeitung, the word can also be associated with Bewältigung, which is often translated as overcoming or mastering. Consequently, the meaning of the English translation remains somewhat ambiguous, lending itself both in the more harmful direction of mastery of the past and in the more helpful direction of processing and understanding the past. It is this latter view of the term that I suggest Adorno has in mind when he contrasts Aufarbeitung and Verarbeitung. Moreover, when Adorno uses the verb verarbeiten in the first few sentences of the essay, he makes clear that the meaning he intends lies in bringing the past to consciousness. He writes: "With working through the past, one does not mean in every usage that one works upon the past in earnestness, breaking its spell through a lucid consciousness." ${ }^{8}$ Thus, Adorno already ties the meaning of "working upon" (verarbeiten) to the idea of consciousness raising that we will discuss in this chapter.

In this essay, Adorno recognizes the hypocrisy of those who believe that the past should be reconciled, bringing forgiveness for injustices, since those who espouse such claims are the very ones who committed the injustices. The problem with striving for forgiveness is indeed the unexamined, and perhaps all-too-often unconscious, assumption (or hope) that forgiveness would

\footnotetext{
${ }^{6}$ Rolf Tiedemann and Henry W. Pickford, notes to Theodor Adorno, "The Meaning of Working through the Past," 477.

${ }^{7}$ Ibid.

${ }^{8}$ Theodor W. Adorno, "Was bedeutet: Aufarbeitung der Vergangenheit," in Ob nach Auschwitz noch sich leben lasse: Ein philosophisches Lesebuch ed. Rolf Tiedemann (Frankfurt am Main: Suhrkamp, 1997), 31. In this instance I have provided my own translation from the German text.
} 
also bring forgetfulness. ${ }^{9}$ As he critiques this telos-driven view of working through the past, Adorno speaks of two reasons for wanting to free oneself of the burden of the past: "One wants to break free of the past: rightly, because nothing at all can live in its shadow, and because there will be no end to the terror as long as guilt and violence are repaid with guilt and violence; wrongly, because the past that one would like to evade is still very much alive." ${ }^{10}$ As one who once questioned the possibility of writing poetry after Auschwitz, or philosophizing after Auschwitz, or even living after Auschwitz, Adorno sympathizes with the desire to escape from under the cloud of terror and guilt that remained in the wake of the Holocaust. However, he (and a number of other German writers) also realizes that the past is not dead-it is not even past. ${ }^{11}$ So long as the possibility of a reprisal of the events of the Holocaust exists, then this past must not be worked through in such a way that it could be considered settled and successfully put out of one's mind.

As a result, Adorno argues in this essay for a means of working upon the past that begins with enlightenment, exemplified by what he describes as a turn toward the subject. This turn to the subject involves critical self-reflection on the part of individuals, and it requires us to examine the factors that created the possibilities for National Socialism and rabid anti-Semitism not as objective factors, but as subjective. A democratic pedagogy, he writes, must lead to enlightenment, since "[a]bove all, enlightenment about what has happened must work against a forgetfulness that all too easily turns up together with the justification of what has been

\footnotetext{
${ }^{9}$ As mentioned earlier, Gad Horowitz discusses the problematic notion of seeking forgiveness for actions taken (or not taken) during the Holocaust. Horowitz views forgiveness as one more means of letting off the hook those who continue to espouse anti-Jewish views. Gad Horowitz, "Global Pardon: Pax Romana, Pax Americana, and Kol Nidre" (December 2001) <http://bad.server.org/issues/2001/58/horowitz.html>. ${ }^{10}$ Ibid.

${ }^{11}$ The phrase "The past is never dead. It's not even past" comes from William Faulkner's Requiem for a Nun, Act One, Scene III.
} 
forgotten..."12 This enlightenment directs itself toward the subjective individual, rather than working through repetition of facts. The subject must be addressed directly, requiring critical self-reflection. "A working through of the past understood as enlightenment is essentially such a turn toward the subject, the reinforcement of a person's self-consciousness and hence also of his self." ${ }^{, 13}$ Adorno describes this turn to the subject in three areas: in issues of guilt and what remains present in one's conscience; in politics and, specifically, the burgeoning German democracy; and in cultural and individual anti-Semitism.

\section{Guilt and Consciousness}

Early on in "The Meaning of Working Through the Past" Adorno discusses the "guilt complex" felt by many in the post-war years, but he suggests there is "something untruthful" about such talk. ${ }^{14}$ He names the term "guilt complex" as a sort of cliché used to coerce people into thinking that the guilt "is actually no guilt at all but rather exists in them, in their psychological disposition: the terribly real past is trivialized into merely a figment of the imagination of those who are affected by it." ${ }^{\prime 15}$ Alternatively, perhaps the guilt, he suggests tongue-in-cheek, is merely a pathological complex that healthy persons avoid by living in the present, rather than carrying the weight of the past. Adorno, thus, questions whether it is truly healthy in a psychological or social sense to remove oneself from the burden of guilt, as if the event never happened. Would working through the past in this sense really serve to assuage one's guilt, or would it simply result in the loss of a painful but necessary history, one that, if remembered, could perhaps keep the past from being repeated? Here Adorno sharply reminds his reader of the power and importance of memory, poignantly noting that, if working through

\footnotetext{
${ }^{12}$ Adorno, "The Meaning of Working Through the Past," 14.

13 Ibid., 17.

${ }^{14}$ Ibid., 5.

${ }^{15}$ Ibid.
} 
the past results in the destruction of memory, then "[ $\mathrm{t}]$ he murdered are to be cheated out of the single remaining thing that our powerlessness can offer them: remembrance." 16 The problem of forgiving and forgetting is then two-fold: first, it finds its solution in an erasure or an effacement of the past, wiping clean the history books in order to remove its burden; and second, it results in an injustice to those who were murdered by removing the possibility of remembrance and hastily embracing the opportunity to move forward with the past securely in the past.

In opposition to the view that some real psychopathology is at work in the German populous, Adorno believes that the problem lies not in the unconscious repression of painful memories, but rather in the quite conscious desire to forget:

The effacement of memory is more the achievement of an all-too-alert consciousness than its weakness when confronted with the superior strength of unconscious processes. In the forgetting of what has scarcely transpired there resonates the fury of one who must first talk himself out of what everyone knows, before he can talk others out of it as well. ${ }^{17}$

Adorno does not deny the reality of feelings of guilt. What he argues against is the rhetoric around such feelings that surfaces as self-serving talk intended to expunge one's guilty conscience. This sort of rhetoric strives for a working-through of the past, rather than a workingupon the past that would result in enlightenment through a turn to the subject. Instead of consciously trying to forget, Adorno suggests one keep in one's consciousness precisely those aspects of the past that one wants to repress. The more conscious one becomes through critical self-reflection, the greater a chance one has of remembering the past and guarding against a final working through of the past that results in the effacement of memory.

Of course, requiring deleterious memories and emotions to remain at the conscious level (which some might see as reproachful) could also run the risk of provoking a vehement backlash against the need to remember. Nevertheless, Adorno argues:

\footnotetext{
${ }^{16}$ Ibid.

${ }^{17}$ Ibid., 6.
} 
It seems to me, rather, that what is conscious could never prove so fateful as what remains unconscious, half-conscious, or preconscious. Essentially, it is a matter of the way in which the past is made present; whether one remains at the level of reproach or whether one withstands the horror by having the strength to comprehend even the incomprehensible. ${ }^{18}$

Reproach and the laying on of guilt do not represent the goals of enlightenment through critical self-reflection; they are not the goals of those who intend to work upon the past, in Adorno's meaning of the phrase. Rather, as Adorno demonstrates here, maintaining memory of the past in the present must be done through attempts at comprehension.

In "Education after Auschwitz," Adorno introduces the term reified consciousness, by which he means "a consciousness blinded to all historical past, all insights into one's own conditionedness, and [a consciousness that] posits as absolute what exists contingently." ${ }^{19}$ His formulation, as presented in this essay, reaches back to his work in The Authoritarian Personality, in which Adorno describes the type of personality who could commit mass murder and orchestrate such a ruthless and horrific undertaking as the Holocaust. What he terms the manipulative character is the personality type which he sees as most easily swayed by and taken over into Fascism. He writes of it as containing "a kind of compulsive overrealism which treats everything and everyone as an object to be handled, manipulated, seized by the subject's own theoretical and practical patterns. ${ }^{, 20}$ Numerous scholars, mostly on the grounds of a flawed research methodology, have disputed Adorno's work in The Authoritarian Personality; yet his conception of the reified consciousness is quite capable of standing on its own without recourse to his description of the manipulative character, and thus it remains a valid notion. The concept of reification emerged from the Marxist thought of Georg Lukács in which it was tied to the

\footnotetext{
${ }^{18}$ Ibid., 15.

${ }^{19}$ Theodor W. Adorno, "Education after Auschwitz," in Can One Live After Auschwitz?: A Philosophical Reader, ed. Rolf Tiedemann and trans. Henry W. Pickford (Stanford, CA: Stanford University Press, 2003), 28.

${ }^{20}$ Theodor W. Adorno, et al, The Authoritarian Personality (New York: W.W. Norton \& Company, Inc., 1969), 767.
} 
structure of exchange society. Brian O'Connor describes the notion of reification in Marxist thought: "For its operation exchange requires a purely quantitative world, and this can only be realized by the translation of qualities into abstract value." ${ }^{21}$ Reification legitimates this process by creating and upholding the illusion that such a translation is a natural product of human nature. Adorno argues that not only does society reify things such as labor or art so as to be commoditized, but subjects too become reified as socially useful external entities, "abstract subjects linked only to other subjects by the principle of exchange."22 This reified consciousness is anathema to the type of consciousness for which Adorno calls. The reified consciousness keeps persons from the sort of critical self-reflection required for uncovering those aspects of collective and individual consciousness that permitted the success of Fascism. Education and enlightenment intended to awaken persons from the state of the reified consciousness represent, in Adorno's view, perhaps the only real possibilities for preventing a recurrence of the Holocaust. He strongly asserts of the reified consciousness that "the inability to identify with others was unquestionably the most important psychological condition for the fact that something like Auschwitz could have occurred in the midst of more or less civilized and innocent people."23

Reified consciousness is tied to the examination of guilt because the myopic desire to rid oneself of one's guilt makes precisely the same move as reification: a turn toward objectivity and away from the subject. Consequently, Adorno sees the focus upon guilt as an exercise in creating external objects upon which one can deposit guilt. The most dangerous form of this occurs in attempts to turn victims into the guilty party, as he notes in "Education after Auschwitz." "It is not the victims who are guilty, not even in the sophistic and caricatured sense

\footnotetext{
${ }^{21}$ Brian O'Connor, Introduction to The Adorno Reader (Malden, MA: Blackwell Publishers, 2000), 13.

${ }^{22}$ Ibid.

${ }^{23}$ Adorno, "Education after Auschwitz," 30.
} 
in which still many today like to construe it." ${ }^{24}$ Rather, to the contrary, guilt remains with those who without reflection directed their anger and hate upon the victims - those who we name as perpetrators. Even this understanding of guilt in relation to the Holocaust has been dissected and examined by writers such as Hannah Arendt and Zygmut Baumann. In her seminal work on the subject, Eichmann in Jerusalem: A Report on the Banality of Evil, Arendt evaluates the degree of guilt with which Adolf Eichmann and others who assisted in perpetrating the so-called "Final Solution" could be assigned. Arendt quotes one of the judges presiding over Eichmann's trial who comments that "in general the degree of responsibility increases as we draw further away from the man who uses the fatal instrument with his own hands." ${ }^{25}$ Additionally, Baumann outlines in Modernity and the Holocaust the ways in which responsibility is spread thin in a bureaucratic, modern society. ${ }^{26}$ Hundreds, perhaps thousands, took part in implementing the Final Solution, each carrying out only his or her own role, oftentimes without the ability to see the larger, overall plan. Thus, no one individual felt directly responsible or guilty for the events that transpired. Both Arendt and Baumann, in their own ways, deconstruct the notion that there can be any direct assignation of guilt to an individual or that a single individual can him or herself represent the guilty party. Nevertheless, the notion of guilt cannot and must not be entirely withdrawn from the Holocaust, nor can one finally surmise that individuals possess no responsibility for the end effects of the Final Solution. Questions remain regarding exactly who is guilty and to what degree persons may be said to be guilty of perpetrating the events of Auschwitz. Adorno remains quite comfortable assigning guilt to those who he sees as perpetrators, though it is not entirely clear just what results in one's designation as perpetrator.

\footnotetext{
${ }^{24}$ Ibid., 21.

${ }^{25}$ Hannah Arendt, Eichmann in Jerusalem: A Report on the Banality of Evil (New York: Penguin Classics, 2006), 247.

${ }^{26}$ Zygmut Bauman, Modernity and the Holocaust (Ithaca, NY: Cornel University Press, 2000).
} 
The question of guilt in relation to the Holocaust remains a complex question. Yet when Adorno places guilt upon those who were unreflective regarding their outward manifestation of inward emotions and prejudices he does so unabashedly. Both "Education after Auschwitz" and "The Meaning of Working through the Past" argue strongly for critical self-reflection in order to keep the guilty from placing their guilt upon some other object, be it the victims themselves or some notion of a guilt complex. As a result, "One must labor against this lack of reflection, must dissuade people from striking outward without reflection upon themselves." ${ }^{27}$ Working upon the past, for Adorno, requires this turn to the subject, a subject who exists in the present and must reflect critically upon the past.

\section{Democracy, Fascism, and German Politics}

The bulk of Adorno's "The Meaning of Working through the Past" deals with the political implications of coming to terms with the past. Adorno turns his critique to the newly installed democracy of post-war Germany, questioning its ability to withstand the effects of forgetting. Forgetfulness, he notes, would leave open the possibility of an easy regression into the fascism of recent past. Moreover, inasmuch as democracy always remains a fallible system, he questions whether it will ever be invulnerable to the consequences of a hasty forgetfulness. Ultimately, he thinks it will not.

Adorno writes that democracy likely had a stronger hold in Germany after the Second World War than it did after the First because of, and not in spite of, the effects of National Socialism. Insofar as National Socialism engendered an anti-feudal and bourgeois milieu, it aided in preparing the way for democracy. Consequentely, Adorno views democracy as a thoroughly bourgeois manifestation that ends up removing individual autonomy, against its own

${ }^{27}$ Ibid. 
espoused ideals (which we will discuss in greater detail below). While he affirms that democracy had certainly taken better hold after World War II than in the Weimar period, he continues to view democracy in Germany as tentative or provisional at best. "What can be said is that the system of political democracy certainly is accepted in Germany in the form of what in America is called a working proposition... But democracy has not become naturalized to the point where people truly experience it as their own and see themselves as subjects of the political process. ${ }^{28}$ Adorno writes that Germans talked openly of being too immature for democracy, a statement that Adorno seems to see as group obfuscation.

In reality, Germans tended toward idealizing and glorifying the period of National Socialism. He describes the persistence of a weakened memory, since National Socialism fulfilled certain "collective fantasies of power" for those who had no power outside of the Nazi system. ${ }^{29}$ The weakened memory remembers only the positive associations, glossing over or pushing aside the negative aspects of the past. Moreover, National Socialism, he argues, served to increase the collective narcissism that resulted in national vanity, or extreme nationalism. While this vanity undoubtedly deflated a great deal with the downfall of Hitler and the collapse of National Socialism, "the damage [to the collective narcissism] occurred at the level of factuality, without individuals making themselves conscious of it and thereby coping with it. This is the social-psychological relevance of talk about the unmastered past." ${ }^{, 30}$ Adorno makes clear that the past remains unmastered because the social-psychological motivations of the past remain at an unconscious level. Neither the passage of time nor the transition into democracy has removed the national vanity of the Nazi era. Rather, "secretly, smoldering, unconsciously, and therefore all the more powerfully, these identifications and the collective narcissism were not

\footnotetext{
${ }^{28}$ Adorno, "The Meaning of Working through the Past," 7.

${ }^{29}$ Ibid., 10 .

${ }^{30}$ Ibid.
} 
destroyed at all, but continue to exist." 31 Surreptitious nostalgia for National Socialism constitutes a more dangerous and more powerful bane to burgeoning democracy than its more overt form, which can be recognized and addressed. Indeed, this collective narcissism remains under the surface awaiting a point at which it can seize upon "anything that brings the past into agreement with the narcissistic desires," seeking always to create the appearance that no damage to the narcissism had ever been done. ${ }^{32}$

Adorno describes the type of nationalism that had taken hold in Nazi Germany as pathological nationalism: "nationalism as a paranoid delusional system," afraid of everything different, everything outside the bounds of the nation's own aims and desires. ${ }^{33}$ In the age of the international economy and the age of cooperation between nations for the greater good of society, nationalism is no longer necessary as a means of protecting the citizens of a nation from the threat of feudalism or the threat of factors intent on breaking up the nation. Nationalism is obsolete, Adorno tells us, and yet it is also up-to-date in the sense that it adapts itself in this paranoid delusional way so as to react against whatever factors it deems a threat to internal unity. Thus, the pathological nationalism of National Socialism combined with already-present antiSemitism to produce the delusional mania that fueled decisions leading to the Final Solution.

Because collective narcissism persists in perpetuating nostalgia for National Socialism and because of the ease with which such a paranoid delusional nationalism could return to German society, Adorno surmises that fascist tendencies persist in the present. "That fascism lives on," he writes, "that the oft-invoked working through of the past has to this day been unsuccessful and has degenerated into its own caricature, an empty and cold forgetting, is due to

\footnotetext{
${ }^{31}$ Ibid., 10-11.

${ }^{32}$ Ibid., 11.

${ }^{33}$ Ibid., 12 .
} 
the fact that the objective conditions of society that engendered fascism continue to exist." 34 These objective conditions remain even within the new-formed democracy, Adorno argues, because people must give themselves over to conditions beyond their control. The economic order of democracy binds people to a system in which they must yield their autonomy; "they must negate precisely that autonomous subjectivity to which the idea of democracy appeals; they can preserve themselves only if they renounce their self." 35 Adorno thus suggests that the requirement of individual identification with the economic and political order maintains, even within democracy, the potential for a return to fascism.

Consequently, the sort of working through of the past that ends in simply putting the past out of sight and out of mind has not, in fact, achieved anything positive or helpful. The "empty and cold forgetting" removes the warning signs and cautionary tales of a helpful memory of the past. Because the past is not dead, merely refusing to recognize and examine it engenders the possibility for feelings, attitudes and events supposedly put behind to creep back in. The democratic political system will not shield society from this possibility. To the contrary, it creates the possibility. Again, Adorno turns to enlightenment on the social and individual level as the means for appropriately remembering and appropriating the past.

Adorno admits that perhaps democracy after 1945 took hold more strongly than it had in the Weimar period, and as a result perhaps the past could be worked upon in such a way as to consciously preserve it in the present. Nevertheless, even in periods of general tranquility and economic and political progress, when the process of examining, remembering and working through the past seems to be moving in a positive direction, the tendency to gloss over the atrocities becomes even more strong. He describes a scenario in which parents must respond to

\footnotetext{
${ }^{34}$ Ibid., 13.

35 Ibid.
} 
questions from their children about what happened under Hitler and writes that they might too easily revert to a response that tends to "whitewash their own guilt," and instead speak only "of the good aspects and say that in fact it was not so awful.." ${ }^{36}$ Adorno's warning that the past is not dead, that National Socialism and anti-Semitism will not be expunged solely by touting the line that one has "worked through the past," now clashes with the burgeoning German democracy. When the politicians, the historians, and those who were complicit in the events of the Second World War strive for effacement of the collective memory, then one must be on one's guard. Those who want to forget too quickly, he argues, are perhaps those for whom remembrance is most important.

Therefore, Vergangenheitsbewältigung cannot be seen as a finite process that can one day come to an end, because it has become superfluous. Society will not come to terms with the past by simply allowing the passage of enough time (as if one could quantify exactly how much time must pass before the past automatically reappraises itself). Rather, the past must always be worked upon in the present. Adorno writes, "We are not simply spectators of world history, free to frolic more or less at will within its grand chambers, nor does world history, whose rhythm increasingly approaches that of catastrophe, appear to allow its subjects the time in which everything would improve on its own." ${ }^{37}$ Political conditions that lead to fascism persist, and with these conditions must also persist the continual struggle against an "empty and cold forgetting." Enlightenment about the past does not await some future time in which it will be realized, nor does it end at a particular point. Adorno's essay illustrates precisely that working through the past does not make sense. The past must instead constantly be worked upon in the present, a present that continues indefinitely.

\footnotetext{
${ }^{36}$ Ibid.

${ }^{37}$ Ibid., 14.
} 


\section{Cultural and Individual Anti-Semitism: Its Effect on the Unmastered Past}

In the last few pages of "The Meaning of Working through the Past," Adorno addresses the pervasive and pernicious anti-Semitism of German society, both pre- and post-World War II National Socialism. He illustrates the need for psychoanalysis as an accompaniment to critical self-reflection, remarking that in Germany Freudian psychoanalytic theory had been widely dismissed and even repressed. Chalking this up to the effects of anti-Semitism, Adorno argues that German intellectuals repressed Freudian psychoanalysis not only because Freud was a Jew, but also "because psychoanalysis consists precisely in the critical self-reflection that makes antiSemites livid with rage."38 If psychoanalysis were admitted into the intellectual environment and into institutions, he writes, it would, at the very least, ensure some amount of reflection upon oneself and upon whatever one's own consciousness most stridently desires to suppress. Therefore, psychoanalysis and enlightenment through critical self-reflection, for which Adorno repeatedly advocates in this essay, would serve to squelch anti-Semitism.

Indeed, outside of such self-reflection, little recourse remains for eliminating wide-spread hatred of Jews. Adorno denounces as viable avenues both propaganda and concrete experiences with the Jewish "other." Recourse to propaganda, he argues, leaves one little better than the totalitarians against which he writes. After all, propaganda is simply "the rational manipulation of what is irrational,"39 a technique frequently employed by the Nazis to the detriment of Jews. Those struggling to fight anti-Semitism cannot merely turn around those tactics used in the name of anti-Semitism. Moreover, propaganda that aims at promoting positive contributions of "the Jews" only serves to reify the already anti-Semitic claim that the Jews are a unified group against which one can direct one's hatred. The sort of reliance on facts that propaganda requires will not

\footnotetext{
38 Ibid., 16.

${ }^{39}$ Ibid.
} 
affect the anti-Semites, who either will not admit the validity of the facts or will maintain that facts only point to exceptions of the general rule. ${ }^{40}$ Thus, Adorno concludes: "Whatever happens by way of propaganda remains ambiguous." ${ }^{41}$ Likewise, he sees little hope in concrete experiences between Jews and anti-Semites (or, as in the case he notes, between Germans and young Israelis) that are intended to promote friendship and understanding. "All too often," he writes, "the presupposition is that anti-Semitism in some essential way involves the Jews and could be countered through concrete experiences with Jews, whereas the genuine anti-Semite is defined far more by his incapacity for any experience whatsoever, by his unresponsiveness." ${ }^{42}$ In this statement he raises two highly significant points: First, he names the assumption that anti-Semitism has something to do with the Jews, as if they have at some level engendered the hatred aimed against them, and as if simply becoming acquainted with a Jew on a personal level would rid one of the belief that all Jews fit the negative stereotypes erected against them. It seems that Adorno intends to point out here that this form of thinking dangerously presupposes that the stereotype has its basis in some real facts or characterizations that most (but not all) Jews tend to portray, a presupposition he obviously will not affirm. Second, in his denunciation of corrective programs based on personal experience he pinpoints the real source of the problem: reification.

In The Authoritarian Personality, Adorno writes: "Anti-Semitism is reified, an export article: it must "function.",43 Anti-Semitism was made to function as a socially useful entity, objectified and divorced from subjectivity. The anti-Semite, to follow Adorno's statement above, cannot eradicate hatred for the Jews on the basis of personal experience or personal knowledge

\footnotetext{
${ }^{40}$ Ibid., 17.

${ }^{41}$ Ibid., 16.

${ }^{42}$ Ibid.

${ }^{43}$ Adorno, The Authoritarian Personality, 768.
} 
of facts because the anti-Semite possesses the reified consciousness that removes subjectivity from the Jews, circumscribing them as the objective other, made to function socially as the scapegoat for economic and political turmoil. To demonstrate this reified view of "the Jews" Adorno cites the National Socialist joke that if the Jews did not exist, then the Nazis would have had to create them. "Anti-Semitism is so difficult to refute," he writes, "because the psychic economy of innumerable people needed it and, in an attenuated form, presumably still needs it today. ${ }^{\circ 4}$ In this argument Adorno also questions the assertion that the anti-Semites are the generative force behind anti-Semitism, suggesting rather "anti-Semitism primarily has its foundation in objective society..." ${ }^{, 45}$ If he is correct, then, anti-Semitism arose as a product of reification through an economy of exchange, and not as a result of some deep-seated and inherent anti-Semitic attitudes.

In Dialectic of Enlightenment, Adorno and his colleague Max Horkheimer traced the rise of anti-Semitism by precisely these means, through the various modes of production up to the time of their writing, in a chapter entitled "Elements of Anti-Semitism: Limits of Enlightenment." Rolf Tiedemann, in his introduction to Ob nach Auschwitz noch sich leben lasse, describes the argument posed by Adorno and Horkheimer:

The individual Jew ceased to be a real, living, suffering human being. As a member of the Jewish people he was reduced to a mere instance, an abstraction, in whom concrete difference merged in indistinguishable sameness...Ever since socially organized labor emerged, it has followed the same pattern: given nature enters into the labor process, but only to the extent that it is needed for the purpose at hand. Whatever is not needed is left lying by the wayside on the road of progress; as a merely potential human quality, it is treated with disdain. ${ }^{46}$

\footnotetext{
${ }^{44}$ Adorno, "The Meaning of Working through the Past," 16.

${ }^{45}$ Ibid.

${ }^{46}$ Rolf Tiedemann, Introduction to Can One Live After Auschwitz: A Philosophical Reader, ed. Rolf Tiedemann (Stanford, CA: Stanford University Press, 2003), xxi.
} 
"Elements of Anti-Semitism" outlines the process of reification, citing the coercive power of the exchange economy to overcome the positive contributions of education and reflection necessary for subjectivity. Both the paranoia of nationalism and false projection (the drive to make all people the same), in which Adorno and Horkheimer see the basis of anti-Semitism, remove the ability to reflect, to think, and thereby to be a subject and view others subjectively outside of the tendency toward a reified consciousness. These factors, provoked by the economy of exchange, result in a reification of "the Jews." As Adorno and Horkheimer note, the conscience is grounded in its ability to view something external to itself, such as another subject, as substantial and worthy of one's own concern. "This ability involves reflection as an interpenetration of receptivity and imagination. Because the abolition of the independent economic subject by big industry... is irresistibly eroding the basis of moral decisions, reflection, too, must wither., ${ }^{47}$ The atrophy of reflection results in a basic inability to think for oneself, a turn toward stupidity, which Adorno and Horkheimer understand as the degeneration into stereotypical thinking propagated by the party in power. Between 1933 and 1945, the National Socialists rigorously reinforced negative stereotypes of the Jews, stoking the fires of a rampant anti-Semitism.

Inasmuch as Dialectic of Enlightenment denotes the basis of anti-Semitism in the changing modes of production, Adorno already refutes the argument of Daniel Goldhagen, some fifty years prior to its arrival, that the German "identity" carried within it an embedded and virulent anti-Semitism. ${ }^{48}$ The problems with Goldhagen's argument are too numerous to be recounted here (though I shall return to them briefly in the final chapter); it is only necessary to restate that Adorno views the modes of production and a society based on the exchange economy

\footnotetext{
${ }^{47}$ Max Horkheimer and Theodor W. Adorno, Dialectic of Enlightenment: Philosophical Fragments, ed. Gunzelin Schmid Noerr and trans. Edmund Jephcott (Stanford, CA: Stanford University Press, 2002), 164.

${ }^{48}$ Goldhagen introduces this argument in Hitler's Willing Executioners: Ordinary Germans and the Holocaust (New York: Alfred A. Knopf, Inc., 1996).
} 
as much more to blame than any inherent anti-Semitism, a notion he does not seem to buy into in the first place, since he and Horkheimer write in Dialectic of Enlightenment "There is no authentic anti-Semitism, and certainly no born anti-Semite." ${ }^{49}$

If anti-Semitism results from the processes of reification and (contra Goldhagen) not from an inborn and deeply subconscious precondition toward hatred of the Jews, then the relation of anti-Semitism to the problem of coming to terms with the past becomes all the more significant. One cannot simply "come to terms" with an innate predisposition toward antiSemitism. Instead, one must work upon the past through critical self-reflection in order to deconstruct reifications imposed by a reliance on and preference for the economies of exchange. The very reflection he sees as atrophied at the hands of economic factors remains the primary means for eliminating anti-Semitism. Returning to Adorno's argument in “The Meaning of Working through the Past," since anti-Semites will not listen to facts, or will only neutralize them and treat them as exceptions, he suggests instead that "one should apply the argumentation directly to the subjects whom one is addressing. They should be made aware of the mechanisms that cause racial prejudice within them." ${ }^{, 50}$ It is at this point that Adorno calls for a return to the subject, for a "reinforcement of a person's self-consciousness and hence also of his self.", A return to the subject entails both a return to the individual person (in this case, the anti-Semitic subject), so as to begin the process of enlightenment through critical self-reflection, as well as a return to subjectivity as a renunciation of the objectification that occurs through reification.

Yet Adorno seems to waiver in the final few sentences of his essay, questioning whether addressing objective problems subjectively will prove successful in the end. He surmises that perhaps objective problems, such as anti-Semitism, nostalgia for the period of National

\footnotetext{
${ }^{49}$ Horkheimer and Adorno, Dialectic of Enlightenment, 140.

${ }^{50}$ Adorno, "The Meaning of Working through the Past," 16.

51 Ibid.
} 
Socialism, and guilt resulting from the atrocities of the Holocuast, must be countered objectively. The only reason he gives for this change in his position is that "in view of the objective power behind the continuing potential of anti-Semitism, subjective enlightenment will not suffice...If one wishes to oppose the objective danger objectively, then no mere idea will do... ${ }^{, 52}$ He goes on to suggest that confronting people with the negative effects of their prejudice and of National Socialism, namely the bombed-out buildings, cities in ruins, may be the only means of effecting any change in their attitudes. Demonstrating the objective conditions that weigh upon individual subjects most heavily becomes his primary focus for eliminating anti-Semitism.

\section{Adorno's Turn to the Subject as Working Upon the Past}

In 1967, when he presents his lecture on "Education after Auschwitz," Adorno seems to have (re)turned once again to the subject and away from a reliance on objective conditions as the means for dissuading persons from reverting to rampant anti-Semitism. At the outset of this essay, he describes Auschwitz (the moniker he uses to name the atrocities of the Holocaust) as a relapse into barbarism, writing that the only way out of the objective conditions of society (still in existence) that allow such a relapse comes about through a return to the subject. "One must come to know the mechanisms that render people capable of such deeds, must reveal these mechanisms to them, and strive, by awakening a general awareness of those mechanisms, to prevent people from becoming so again." ${ }^{, 53}$ As mentioned above, he goes on in this essay to articulate education as a means of critical self-reflection through which individuals may become enlightened so as to prevent the recurrence of Auschwitz. Given this later return to the subject, one can understand Adorno as not having ultimately given up on subjective conditions. While frustration with the suppression of psychoanalysis and other factors may have led him in 1959 to

\footnotetext{
${ }^{52}$ Ibid.

${ }^{53}$ Adorno, "Education after Auschwitz," 21.
} 
the determination that subjective enlightenment simply was not yet possible, nearly a decade later he appears eager to return to critical self-reflection in an effort to undo the reified consciousness to which people had become assimilated.

Adorno's injunction to "work upon," rather than to "work through," the past becomes the process of working upon the present, so as to root out the causes of harmful past events. ${ }^{54}$ This working-upon manifests itself as Adorno's turn to the subject, and in "Education After Auschwitz" this turn takes the form of education at both the individual level and within the general collective conscience. The latter of these focuses specifically on the need to address the deleterious past and bring it to consciousness, since the enlightenment he describes aims at providing "an intellectual, cultural, and social climate in which a recurrence would no longer be possible, a climate, therefore, in which the motives that led to the horror would become relatively conscious." 55 As Jürgen Habermas noted in an essay from 1992, “Adorno’s commitment to 'working off' our own past, however, does not represent starry-eyed trust in the dynamics of bringing-to-consciousness, but reflects solely the insight that today, under the conditions of postmetaphysical thinking, there exists no alternative to self-reflection when we seek selfunderstanding., ${ }^{, 56}$ Indeed, Adorno does not intend to tout self-reflection as an easily accomplished, seemingly automated solution for working upon the past. To the contrary, he recognizes the painstaking work that must be done and recognizes that "it would be wholly wrong if we were to preach self-examination and then expect that, because of this sermon, people will examine themselves. That is illusory. What we can do is give people contents, give

\footnotetext{
${ }^{54}$ As we shall see in chapter two, Adorno's notion of “working upon” the past is really quite close to Voegelin's desire for "mastering the present."

${ }^{55}$ Theodor Adorno, "Education After Auschwitz," in Can One Live After Auschwitz?: A Philosophical Reader, ed. Rolf Tiedemann and trans. Rodney Livingstone (Stanford, CA: Stanford University Press, 2003), 22.

${ }^{56}$ Jürgen Habermas, "What Does 'Working Off the Past' Mean Today?" in A Berlin Republic: Writings on Germany, trans. Steven Rendall (Lincoln, NE: University of Nebraska Press, 1997), 18.
} 
them categories, give them forms of consciousness, by means of which they can approach selfreflection. ${ }^{, 57} \mathrm{He}$, therefore, realizes the difficulties inherent in any turn to the subject that seeks to eliminate the tendencies of reification and understands that critical self-reflection will not be an easy task, particularly because it must work against the reifications brought about by the exchange economy while working within precisely this economic system.

Adorno ends "The Meaning of Working through the Past" with a final caution: "The past will have been worked through only when the causes of what happened then have been eliminated. Only because the causes continue to exist does the captivating spell of the past remain to this day unbroken." 58 The importance of complicating the phrase "working through the past" lies in the need to remember, to not work through the past too hastily or in such a way that results in forgetfulness. For the attempt to close the door on the past actually ends up leaving it open—retaining the possibility that something such as Auschwitz could occur once again. As we turn in the next chapter to a critical examination of Eric Voegelin's lectures on the unmastered past, we will probe the ways in which Adorno's injunction to work upon, rather than through, the past compare with Voegelin's own statement that what must be mastered is the present. As I have suggested, working upon the past in the present remains an on-going process that for Adorno becomes possible only through the sort of critical self-reflection that leads to subjective enlightenment on both an individual and a societal level.

Adorno's description of the problem with Vergangenheitsbewältigung establishes the critique of the process of coming to terms with or mastering the past—a critique echoed by Voegelin, as we shall see. Moreover, he highlights the fact that the problems of the past must

\footnotetext{
${ }^{57}$ Recorded as a response given by Adorno in "Discussion of Professor Adorno's Lecture" following the original presentation of "The Meaning of Working through the Past," published in Theodor W. Adorno, Critical Models: Interventions and Catchwords, trans. Henry W. Pickford (New York: Columbia University Press, 1998), 300.

${ }^{58}$ Adorno, "The Meaning of Working through the Past," 18.
} 
remain problems for the present, positioned as moments of experience that should be addressed in the present through critical self-reflection because such problems cannot be relegated to the past. Rather, remembering the past becomes a significant undertaking for Adorno as well as, as subsequent chapters will demonstrate, for Voegelin, Whitehead, Benjamin, and all theologians who attempt to unfold theological options after Auschwitz. The past cannot, must not, be effaced, but rather the past continues to live on in the present, providing the necessary remembrance that enables thoughtful philosophers and theologians to critique harmful aspects of the past and reflect upon ways in which the present and future might provide alternative options to those that engendered such rampant anti-Semitism and fascist nationalism in the past. 


\section{Chapter Two: Eric Voegelin's Critique of the Unmastered Past}

In the summer of 1964 Eric Voegelin offered an introductory political science course at the Ludwig-Maximilians-Universität in Munich entitled "Hitler and the Germans." Throughout the course of these lectures Voegelin, similar to Adorno, deconstructs the notion of Vergangenheitsbewältigung and the Germans' understanding of coming to terms with their Nazi past. Voegelin critiques the way in which the phrase "mastering the past" became an operative cliché in public and popular discourse in post-war Germany. Rather than simply accepting and riding the tide of popular sentiment and intellectualism, he instead questioned the very possibility of mastering the past, asking what a mastery of the past would mean in the first place. Instead of articulating a mastery of the past, Voegelin argues that what must be mastered is the present, suggesting that such a mastery take place through a reorientation of the ethical mandates of all people insofar as they exist in the present as in a presence (Präsenz) under God. This chapter explores Voegelin's lectures on "Hitler and the Germans," giving special attention to his discussion of mastery of the present as opposed to mastery of the past and the means by which Germans might approach this task. In the course of this chapter I will deal with Voegelin's discussion of clichés, including those of the unmastered past, collective guilt, and the state and democracy, before elucidating his concept of mastering the present. Like Adorno, Voegelin offers an excursus into the post-Holocaust German situation that provides the background out of which my theology of remembrance emerges. Yet more importantly, and also similar to Adorno, Voegelin's writing in "Hitler and the Germans" critiques the understanding that such horrific events can or should ever be mastered. Instead, he lends an ethical mandate to the process of effectively confronting and reflecting upon the conditions that made possible such events in the first place from the purview of the present. As we shall see, his philosophy, in which an 
individual remains grounded in relation to transcendence, provides a strong counterpoint to Adorno's historical materialism. Nevertheless, the views of these divergent thinkers will prove fruitful for eliciting the antithesis between transcendence and immanence that we will uncover in the exegesis of Whitehead's dipolar theism.

\section{The Political Philosophy of Eric Voegelin}

Erich Vögelin, born in Cologne, Germany, in 1901, received his degree from the University of Vienna, where one of his advisors was the well-known political theorist Hans Kelsen. ${ }^{1}$ Upon completion of his Habilitation he assumed the position of lecturer at the university in the fields of political theory and sociology. After the National Socialists' rise to power in 1933, Voegelin published two books dealing with Nazi racism, necessitating his flight from Austria after the annexation by National Socialist Germany in $1938 .^{2}$ Voegelin first found refuge in Switzerland before finally settling in the United States and accepting a position at Louisiana State University in the Department of Government in 1942. Only in 1958 did he return to Germany to fill the chair formerly occupied by Max Weber in political science at Ludwig-Maximilians-Universität in Munich, where he also founded the Institut für Politische Wissenschaft. In 1969 Voegelin left Germany for a post at the Hoover Institute at Standford University, where he worked until his death in 1985.

Voegelin has been regarded as one of the pre-eminent political philosophers of the twentieth century. An extremely prolific political scientist, he wrote widely on themes of the

\footnotetext{
${ }^{1}$ Kelsen was most known for his Pure Theory of Law, which formulated a notion of law as built upon a framework of a priori norms. His theory adopted a neo-Kantian methodology, with which Voegelin later found himself in disagreement. Kelsen, an Austrian who assisted in writing the post-World War I Austrian constitution, remained at odds with Carl Schmitt, one of the other prominent Austrian political scientists of the period. Schmitt took the opposite view from Kelsen, looking for the exception to the norm and for the in-breaking of the unconditional. ${ }^{2}$ Race and State and The History of the Race Idea, originally published in 1933, now available in The Collected Works of Eric Voegelin, volumes 2 and 3 respectively.
} 
state and representation, philosophy of history, and religion as it comes to manifest itself within the political sphere. Significant for this work are his notions of representation and his conception of history. His theory of representation arises at various points in the lectures on "Hitler and the Germans," though it is perhaps most fully developed in The New Science of Politics. Voegelin argues that society functions through representatives, elected or otherwise, who act on behalf of society and, at least ideally, in accordance with the best interests of society. Moreover, "[i]n order to come into existence, a society must articulate itself by producing a representative that will act for it."3 Hence, a society exists only when it enters into the process of representation. Representation takes two modes - an existential mode and a transcendental ${ }^{4}$ mode. In the first, society depends "for its existence on there being a representative who is able to act for it in both internal and external matters." And in the second, the effectiveness of a representative further depends upon her or his ability to represent the transcendent, divine order. The representative should represent the divine order by reason and spirit because it is through recognizing the human relation to the divine through reason and spirit that the human is constituted in the first place. This theory of representation plays a prominent role in Voegelin's examination of Hitler and the failure of German society, as we shall see in this chapter.

Voegelin's philosophy of history also bears significantly on the problem of coming to terms with the past, as it articulates an interpretation of history as necessarily inclusive of humanity's participation in being and in the divine. As Eugene Webb indicates in his book on Voegelin's philosophy of history, "Historical inquiry...is an exploration not only of past events

\footnotetext{
${ }^{3}$ Eric Voegelin, The New Science of Politics: an Introduction (Chicago: University of Chicago Press, 1952) 41.

${ }^{4}$ Transcendental for Voegelin means roughly "pertaining to the transcendent" and not "the condition for the possibility," as it is in the Kantian sense. Indeed, as will be made explicit in this chapter, Voegelin eschews the canalization of linguistic meaning that has occurred since the $18^{\text {th }}$ century in European (and particularly German) philosophy, and so he returns to a pre-Kantian meaning of the term transcendental.

${ }_{5}^{5}$ Eric Voegelin, "Hitler and the Germans" in The Collected Works of Eric Voegelin trans. and ed. Detlev Clemens and Brendan Pucell (Columbia, MO: University of Missouri Press, 1999), 80.
} 
and their interrelations but also of the structure of human existence as a process of participation in being." Voegelin rejects the type of historical inquiry or analysis that relies on constructing a timeline of events or a chronology of data; rather, history should be viewed through the patterns of meaning that arise from events. He disagrees with Marxist and Hegelian historical approaches that assume the unfolding of history to be an inevitable process with a clear end or telos in mind $^{7}$; instead, "it depends on the free response of individuals within the concrete societies they make up; without that response there may be incidents but no history." ${ }^{8}$ Indeed, the history of humanity must include this response on the behalf of individuals. Voegelin returns to Plato's notion of the metaxy, the in-between of humanity and divinity, in order to describe the movement of history. History unfolds as a result of the tension in the metaxy, the tension between the human and the divine, between temporality and eternity. ${ }^{9}$ As Eugene Webb summarizes: "Man [sic] is longing for reality, cognitive and existential; the philosopher is man conscious of his humanity; and history is man written large." ${ }^{10}$ Hence, one can see in Voegelin's philosophy of history the same anthropological principle that drives his political philosophy. It is the Platonic anthropological dictum that the polis is humanity writ large, here brought into service of the philosophy of history.

\section{The Cliché of the Unmastered Past}

Voegelin's lectures on "Hitler and the Germans" have been reconstructed from a series of audio recordings, with section breaks provided by notes from students who attended the lectures. While the lectures were intended as an introduction to political science, Voegelin chose to use

\footnotetext{
${ }^{6}$ Eugene Webb, Eric Voegelin: Philosopher of History (Seattle: University of Washington Press, 1981), 17.

${ }^{7}$ We will later see both Adorno and Benjamin as exhibiting some distance from this form of so-called "vulgar" Marxism.

${ }^{8}$ Ibid., 49.

${ }^{9}$ Ibid., 238

${ }^{10}$ Ibid., 51.
} 
the topic of Germany's attempt to understand Hitler's rise to power as a foray into more general questions posed to the field of political theory. This approach is significant for Voegelin, as his methodology requires an empirical approach to political theory. He states in the introduction to his lectures that an introduction to political science must be undertaken in such a way as to apply general principles to concrete political events: "we must start with specific political experiences, then analyze these and extrapolate from them to such an extent that we arrive at the scientific problems." 11 To this effect, Voegelin cites the problem of Hitler's rise to power as a political event with which both students and the general public in 1964 were intensely interested.

As his introduction continues, he names several recent occurrences in which this question was raised — namely the publication of Percy E. Schramm's “The Anatomy of a Dictator” in Der Spiegel (later republished as the introduction to Hitler's Table Talk ${ }^{12}$ ) and the subsequent series of exchanges, both academic and popular, that Schramm's work incited. Voegelin's (and others') issue with Schramm's essay is that it explicitly ignores preceding literature on Hitler, focusing instead on personal attributes, refusing to deal with those things that made Hitler a prominent and well-liked political figure, those very things that created the possibility for his rise to power. Voegelin then reviews various letters to the editor published after a response to Schramm's “Anatomy” by Albert Wucher in the Süddeutsche Zeitung, pausing on one response that typifies what Voegelin names the "Buttermelcher Syndrome" (since the letter's author came from the German town of Buttermelcher). The "Buttemelcher Syndrome" can be summarized as the argument that "Hitler cannot have been as dubious as he was, since then the entire generation would have been just as dubious." ${ }^{\prime \prime}$ If Hitler was stupid and criminal, then the entire population

\footnotetext{
${ }^{11}$ Voegelin, "Hitler and the Germans," 51.

${ }^{12}$ Henry Picker, Hitlers Tischgespräche im Führerhauptquartier 1941-1942, ed. Percy Ernst Schramm (Stuttgart: Seewald Verlag, 1963).

${ }^{13}$ Voegelin, "Hitler and the Germans," 58.
} 
that elected him chancellor must also have been stupid and criminal. Clearly this would not be an easy premise for the German populace to accept, which is part of the problem Voegelin cites regarding Hitler's rise to power. Indeed, Voegelin refutes the idea that Hitler was stupid or idiotic, suggesting instead that he be examined as a Stultus, a classic fool, meaning that he could well have been both quite intelligent (especially politically) while also acting as a fool.

From this brief introductory sketch of Hitler's foolishness and the Buttermelcher Syndrome, Voegelin's introduction proceeds by citing the present-day (1964) laxity toward former Nazi officials. He ends this build up to the lectures with the following question: "Up to what level is our whole federal-republican society still so riddled in an organized form with National Socialists that it is almost impossible to overcome such things [referring to problems with prosecution of Nazi criminals], especially in the judiciary and in the police service?"14 Thus, his introduction to the lectures sets up the problems Germans still had to deal or "come to terms" with in the mid-1960s. These problems are the very issues he seeks to explore in his lectures, first by examining what he terms a "series of clichés," which served only to further obfuscate these difficult issues.

During the first lecture, in which Voegelin turns to examine the cliché of the unmastered past, he questions the meaning of Vergangenheitsbewältigung, asking: "When we hear the expression 'the unmastered past,' a series of questions immediately crops up: What does that really mean, in the first place? For whom is this past unmastered, assuming that we know at all what 'mastering' means: for all, or for only a few people?"15 With these opening questions Voegelin does not intend to make light of the need to consider the past, rather he wants to

\footnotetext{
14 Ibid., 69.

${ }^{15}$ Ibid., 70. Here Voegelin does use the word Vergangenheitsbewältigung and variations on it. In the original German publication of the lectures, the phrase "unmastered past" appears as "unbewältigten Vergangenheit." See Eric Voegelin, Hitler und die Deutschen, ed. Manfred Henningsen (München: Wilhelm Fink Verlag, 2006 ), 68.
} 
demonstrate that the phrase "the unmastered past" has become a cliché and hence lost its meaning and significance. Additionally, he critiques the idea that the past is something that can be or should be mastered. In fact, for Voegelin, when one can say that something from the past remains unmastered, then the problem lies actually in an unmastered present. He writes: "consequently if there is somehow the feeling that there is still something to master in the past, then we are coming to what I have continually pointed toward in all these examples, that we live in an unmastered present." ${ }^{\text {16 }}$ Thus, like Adorno, Voegelin undermines the supposition that there is any easy way to fix the past or master the past, insofar as it is in the past. Instead, he sees the problem as lying in the present and in the recognition that the present has not examined or come to understand the role of the Nazis and the Holocaust in German history and identity. ${ }^{17}$

Explicating what he means by mastering the present, Voegelin describes two different meanings of the present. First is the traditional understanding of present (Gegenwartspunkt) as a point in time between the past and the future. Under this view, time progresses in a linear fashion, going from past to future and passing through that point which we call the present. The second notion of the present, which is the viewpoint that Voegelin adopts in his critique, conceives of the present as one's existence in her or his presence (Präsenz) under God. ${ }^{18} \mathrm{He}$ adopts this understanding of the present as "presence," noting "the meaning of the past and the future will become generally interpretable only when starting out from this presence. For otherwise everything would proceed irrelevantly in an external stream of time." ${ }^{, 19}$ What Voegelin seeks is a new ethical mandate in which each person realizes her or his place "under

\footnotetext{
${ }^{16}$ Ibid.

${ }^{17}$ Detlev Clemens, "Eric Voegelin's 'Hitler and the Germans' Lectures in the Context of the Germans' Treatment of Their Nazi Past," in Eric Voegelin, "Hitler and the Germans" in The Collected Works of Eric Voegelin trans. and ed. Detlev Clemens and Brendan Pucell (Columbia, MO: University of Missouri Press, 1999), 2.

${ }^{18}$ Voegelin, "Hitler and the Germans," 71.

${ }^{19}$ Ibid.
} 
the judgment of the presence under God. ${ }^{.20}$ In this sense, he describes the problem of mastering the present as a general human problem, and not merely a problem for Germans. Insofar as he appeals to Plato's writings in the Politeia and the Gorgias, Voegelin assumes that all of humanity lies always under judgment: "To place oneself under the presence, under the presence of God, and according to that to adjudicate what one does as man [sic] and how one forms the order of one's own existence and the existence of society, that for Plato is an act of judgment." ${ }^{21}$ For him, political science becomes the examination of immanent society and its failure to place itself under judgment in the presence of God. Moreover, what he ultimately suggests went wrong during the Nazi rise to power was a dissociation in society at large from this notion of presence. Thus, mastering the present can be properly understood, in Voegelin's terms, as the realization that all of humanity is under judgment of the presence under God. In fact, Voegelin quite strongly argues against any conception of mastery of the present (or the past) as occurring through recourse to ideologies. Mastering the present in the sense of invoking and adhering to ideological principles results in an adverse outcome — one that actually prevents any real mastery of the present. In this regard, Voegelin writes: "We have a particular difficulty in mastering our present, since our society is dominated by different kinds of ideological principles and viewsnot only Marxist or National Socialist but also positivist, progressivist, secular-liberal, etc. — that erect the prevention of the mastering of the present into a principle." ${ }^{, 22}$ Such ideologies have been particularly present in German society, reaching back through the past (at least) two hundred years from the advent of the German Enlightenment and the resulting prevalence of Kantian philosophical notions. Therefore, if the present is to be mastered in the sense in which Voegelin intends, then one must undertake the task of "clearing out all the ideological junk in

\footnotetext{
${ }^{20}$ Ibid.

${ }^{21}$ Ibid.

${ }^{22}$ Ibid., 72.
} 
order to make the conditio humana visible once again., ${ }^{, 23}$ By this he does not intend to dismiss or efface all post-Enlightenment Western philosophy, but rather wishes to remove unswerving allegiance to ideological principles derived therefrom insofar as they prevent a mastery of the present and prevent a realization of oneself as existing under judgment as under the presence before God.

If Voegelin's work is to remain alongside the historical materialist thinkers of Adorno and Benjamin in this work, then we must examine his statement against ideologies more carefully. As I have mentioned, Voegelin's issue with ideologies is that they are no longer merely a philosophical system, but rather become a myopic gaze upon the world from a very fixed, rigid position. Clearly, such ideologies are dangerous or have the potential to be dangerous in whatever form they manifest. Yet, the type of historical materialism held by Adorno and Benjamin does not, I contend, fit into this category of ideology. Adorno and Benjamin each revile the so-called "vulgar" materialists who view history as an inevitable progression toward the triumph of socialism. Benjamin's own stance against this position becomes quite clear in his "Theses on the Philosophy of History," to which we shall turn in the final chapter. Thus, on this point I read Voegelin as providing a necessary critique of myopic, fundamentalist ideologies that have a tendency to run rampant, rather than destroying an possible recourse to a historical materialist position. I cannot hide the fact that Voegelin's own view does not align closely with that of Adorno or Benjamin; nevertheless, I am certain he would not call them ideologues.

Voegelin's critique of ideologies, which he refers to as "ideological junk," is pointed most sharply at those philosophies that arose during the $18^{\text {th }}$ century in Germany—most notably

${ }^{23}$ Ibid. 
in the writings of Christian Wolff ${ }^{24}$ and Immanuel Kant, whom he mentions specifically. These ideologies have impeded understanding of the human condition because of their usurpation of meaning from terms used to speak philosophically about "the truth of existence, freedom of existence under God...or about the spirit, etc." 25 In Voegelin's view, the meanings of these words have undergone a fundamental change - they have become ideologized: "Only from that time on do we have a German vocabulary for the treatment of problems, developed during the period of the ideologies and therefore loaded from the beginning with the meanings of the Enlightenment and of Romantic gnosis." ${ }^{26}$ As a result, Voegelin desires a return to pre-Kantian philosophical meanings of such terms, a return to what he deems a proper understanding of "reason," "spirit," and "intellect"—-terms he views as usurped by the post-Enlightenment (and largely German) philosophical tradition. He notes that one cannot speak in Germany of "reason" and assume that listeners understand anything other than what Kant means by "reason" in the Critique of Pure Reason, or speak of "spirit" and meaning anything other than Hegel's meaning of "spirit." Conversely, Voegelin himself wishes to use (and does use) terms such as nous and pneuma with an appeal to the Aristotelian and Platonic meanings of these words. He ardently expresses his view that pre-enlightenment philosophies existed as devoid of such ideologies. What he means by ideologies will be expounded later in the lectures and will be covered later in this chapter. Suffice it to say at this point that ideologies create their own system of meaning and own worldview resulting in the establishment of a reality divorced from concrete reality. In this

\footnotetext{
${ }^{24}$ Wolff is noted as being perhaps the most prominent German philosopher between Leibniz and Kant. Writing in the early to mid- $18^{\text {th }}$ century, he is also credited with making German the language of scholastic writing, as he wrote in both German and Latin (primarily so as to be understood by philosophers outside of Germany). With this history in mind, one can easily see the reason Voegelin charges him with altering the meaning of classical philosophical terms and phrases.

${ }^{25}$ Voegelin, "Hitler and the Germans," 72. In the next chapter we will similar critiques of the metaphysical tradition raised by Adorno also in the context of properly elucidating the human condition, though Adorno's human condition must be one in which humans exist as a part of damaged life.

${ }^{26}$ Ibid., 73 .
} 
regard, he argues that only by ridding oneself of the assumed meanings offered by the various ideologies developed from the $18^{\text {th }}$ century onward can one hope to appropriately or adequately describe the presence under God. Moreover, while he sees this usurpation of meaning present within the German tradition, he believes traditions elsewhere in the West have maintained the more helpful original system of meanings developed by Aquinas, Aristotle, and Plato, finally surmising that "[t]his entire dimension of meaning, where these expressions were indeed created in order to elucidate and express the presence under God, has been essentially suppressed in the German language.,27

Returning to a summation of his primary point in the introduction to the lectures, Voegelin writes: "There is no unmastered past: What is past, is past. There are only unmastered presents. There can indeed have been unmastered presents in the past, too; inasmuch as the past, being the present in its time, was unmastered, this not being mastered reaches into the unmastered present, in historical continuity." 28 When Voegelin writes that "what is past, is past," he does not mean that the past is dead, put behind us never to rear its head again. Rather, he points out that focusing on the past fails to address the problems of the present. And in the present, the problems of the past are already finding ways to reemerge. As previously stated, this present can be conceived of as either a point in time between the past and future or as a presence under God. With regard to this second understanding of presence, Voegelin now succinctly reiterates his point—namely, that

action is always to be judged as action in the world under the orientation of its presence to God. Where that does not happen, the present is unmastered, and even if it sinks into the past, it remains still unmastered; and insofar as this worldly past influences the present in historical continuity, then also the contemporary present remains unmastered. ${ }^{29}$

\footnotetext{
${ }^{27}$ Ibid., 73.

${ }^{28}$ Ibid., 74 .

${ }^{29}$ Ibid.
} 
The failure of society under the regime of National Socialism was such that it lost or dissociated itself from this notion of presence under God, thereby obviating any recourse to an ethical imperative. Action was no longer judged according to a transcendent ideal, but only according to an immanent ideology erected by the tenets and mythology of National Socialism.

\section{The Cliché of Collective Guilt}

The second cliché Voegelin considers is the cliché of collective guilt, which also pertains to the problem of the unmastered past. Denying the possibility of "collective guilt," he asserts instead that guilt must always be attributed to a person. Consequently, collective guilt can be only a cliché and an alibi, which we will discuss in detail below. He subdivides discussion of collective guilt into three areas—-personal, social, and historical—articulating through each how the cliché and alibi of collective guilt hinders one from mastering the present. Here he takes up issues of representational politics and returns again to critiques of the spiritual state of persons in the twentieth century.

In terms of personal guilt, Voegelin cites a turning point in the sixth century BCE wherein societies no longer understood individuals as personally responsible for the transgressions and wrongdoing of previous generations. He quotes from Ezekiel chapter 18 to demonstrate this transition. Here the prophet Ezekiel explains that henceforth only those who commit a wrong will be considered guilty of that wrong, whereas previously punishment for a transgression from a prior generation could have been exacted upon subsequent generations, regardless of whether or not those generations were responsible for this wrongdoing. Following this move, Voegelin surmises: "So, personally there is no liability for something that was done in the past by other people; but the fact that one is not responsible for what a previous generation did does not mean that one is now guiltless and has a right to be up to all sorts of mischief. 
Rather, each one of us is also obliged to be just." ${ }^{, 30}$ His statement here bears directly on a discussion of mastery of the past. One who did not commit atrocities in the past, because one was not yet born, cannot be counted as guilty for those atrocities. Nevertheless, this fact does not expunge individuals in the present from any present or future sense of responsibility for one's actions, including how one acts in light of the events of the past.

The social aspect of collective guilt that Voegelin describes has to do with representation and the social structure. As previously noted, Voegelin adopts a theory of representation such that society functions through representatives, whether elected or otherwise "chosen." The potentially debilitating consequence thereof lies in the fact that "if the representatives do not function, all members of the society, even those who have nothing to do with the representatives' misdeeds, have to bear, along with them, the consequences of these misdeeds, whether they are guilty or not." ${ }^{31}$ Thus, even if Hitler was a criminal imbecile, he was also the elected representative of the German people; therefore, German society became caught up together with Hitler and the National Socialists in their culpability for the Holocaust and the Second World War.

Collective guilt's historical component may be seen in the development of a general mistrust in a society whose representatives act in criminal or otherwise atrocious ways. Voegelin writes that mistrust arises between those within the society who did not partake in such acts and who did not vote for the representative in the first place. Moreover, "those societies that suffer the consequences of these criminal mischiefs maintain for generations the greatest mistrust for a

\footnotetext{
${ }^{30}$ Ibid., 75.

${ }^{31}$ Ibid., 75-76.
} 
society that did such things. ${ }^{32}$ This sort of collective guilt may be considered from a historical aspect because the guilt carries on as history proceeds.

For Voegelin, the whole notion of collective guilt, however, becomes an alibi procedure distracting one's attention from the task of mastering the present, focused instead upon a detailed accounting of the events of the past with no real regard for comprehending or examining the past. This alibi manifests itself in two ways. First, the cliché of collective guilt "expresses itself in an extremely obliging burrowing into the past, in the investigation of all the atrocities that have occurred." ${ }^{33}$ In this manner, so-called "contemporary" historians engage in what Voegelin refers to as "exhibitionism" aimed at exonerating themselves and the German people by simply recounting the whole mass of atrocities that occurred in the past. What this attempt at exoneration through exhibitionism becomes is, in fact, the cliché of mastery of the past. Such historians do not attempt a critical examination and, therefore, do not delve into the problems as they continue to manifest themselves in the present. Voegelin notes that, contrary to a catalog of the atrocities of the past, society actually needs peoples' attitudes in the present to be changed. "So the excessively detailed investigation of the past is one of the alibi procedures in order not to master the present because one blames the past with the guilt one really should deal with in the present. ${ }^{34}$

Second, the cliché of collective guilt becomes an alibi procedure when persons engage in a complete rejection of collective guilt, again in order that one need not attempt to master the present. In this regard, individuals assume they are "not responsible for what happened in the past but [are], however, by no means prepared to do what one should do in order to master the

\footnotetext{
${ }^{32}$ Ibid., 76.

${ }^{33}$ Ibid.

${ }^{34}$ Ibid., 77.
} 
present. ${ }^{, 35}$ They reject the social and historical aspects of collective guilt articulated above, eschewing the idea that they too are bound up with the guilt of those who committed the atrocities as representatives of society and neglecting the historical view of collective guilt in which a general mistrust emerges between the present society and past representatives and their electors.

Assigning blame, pretending to prosecute (while in reality only engaging in a farcical prosecution), will not effectively deal with the attitudes of the present. Neither will outright rejection of collective guilt lead to effective mastery of the present. Voegelin reiterates that recounting past atrocities and blaming National Socialism, which he also deems a cliché, only serves as obfuscation of the real problem. Enumerating the heinous crimes of the past, prosecuting Nazi criminals, and commemorating recognition of these atrocities with monuments and memorials, while not wrong in and of themselves, will not aid in uncovering the much more serious problem, which Voegelin names as "the spiritual condition of a society in which the National Socialists could come to power. ${ }^{, 36}$ The very fact that Germans (by and large) elected Hitler and the National Socialists to power and thereby enabled representatives of society to act on their behalf in such horrific and damnable ways raises serious questions regarding the spirit of the German populous and indeed, as Voegelin extends it, of Western society as a whole: "So it is not the National Socialists who are the problem but the Germans, among whom personalities of the National Socialist type can become socially representative and can function as representatives, as politicians, as Reich chancellors, etc." ${ }^{37}$ Voegelin describes representation in two ways: one, in the lectures, using Justinian as a primary example of how authority manifests itself through the sources of power, reason, and spirit; and the second, as developed in The New

\footnotetext{
${ }^{35}$ Ibid.

${ }^{36}$ Ibid.

${ }^{37}$ Ibid.
} 
Science of Politics, as an existential and transcendental representation. Both formulations result in a representative upon whom society depends for its existence (the existential or power factor) and a representative who must "represent the transcendent order of the divine" (the factors of reason and spirit). ${ }^{38}$ What happened under Hitler, Voegelin argues, was that this formulation of representation fell apart-Hitler as representative proved to be existentially effective, but possessed neither reason nor spirit.

As a result, three possibilities arise. First, it is possible that Hitler, because of his great success, cannot be seen as contemptible in any sense. Second, Hitler was undoubtedly contemptible by virtue of the fact that he altered human history through his own irrationality. And third, a world that allows someone as irrational as Hitler to alter the course of human history must itself be contemptible. This returns us to the Buttermelcher syndrome encountered above: "that is, that all who cooperated would have to admit that if the man was rationally and spiritually contemptible then they too were contemptible." ${ }^{39}$ It is here where Voegelin's own view seems to rest. The world that elected Hitler as social representative must be just as contemptible as Hitler himself. Neither Hitler nor the world in which he came to power possesses the spiritual means to act justly and represent the transcendent order of the divine. He thus closes this section of his lectures with the following comments:

...there now arises a task for us, which is precisely not to allow this achievement of Hitler's to be lost but to make conscious the contemptibility that he highlighted, the contemptibility of the others, to describe it exactly in precise detail and to know it, in order to prevent oneself in the future from becoming as contemptible as the people Hitler dealt with and to whom he owed his success. And that is the mastering of the present that you are called to and that one cannot escape by taking up the atrocities of the past. ${ }^{40}$

\footnotetext{
${ }^{38}$ Ibid., 80 .

${ }^{39}$ Ibid., 81 .

${ }^{40}$ Ibid., 82 .
} 
Here we have perhaps Voegelin's most salient explication of the necessity of mastering the present (and not the past) in the lectures thus far. If mastery of the past ends only in a detailed and empty accounting of past atrocities, then mastery of the present must be more-it must involve honest evaluation and alteration of attitudes in the present such that we raise to consciousness the contemptibility of Hitler and those who made possible Hitler's rise to power and his actions as social representative.

\section{Dedivinization, Dehumanization, and First and Second Reality}

After briefly explaining why the terms "state" and "democracy" have attained the status of cliché, Voegelin unfolds a robust anthropological account based on the notion of presence under God. Succinctly stated, "state" and "democracy" became clichés in post-war Germany because, with regard to the former, Western philosophy ideologized the term, rendering it virtually ineffectual and, with regard to the second, German society, insofar as it was a (late) newcomer to democracy, comprehended only a partial formulation of what democracy actually entails. Voegelin cites Hegel's vision of the "state" as it appears in his Philosophy of Law, in which Hegel writes that the state is an elevated form of the self-consciousness that actualizes an ethical ideal. ${ }^{41}$ This view becomes a cliché for Voegelin because it abstracts the concept of the state away from the level of humanity and humans as representatives. Instead, politics, he writes, makes it its business to understand the individuals who constitute and found the state. The cliché of democracy also deals with the function of individuals in society, since true democracy requires self-restraint on the side of those individuals who represent society. Representatives must refrain from exercising one principle of democracy to the detriment of the others. For example, Voegelin quotes Mark Twain's definition of democracy as “freedom of speech,

\footnotetext{
${ }^{41}$ See G.W.F. Hegel, Philosophy of Right, trans. T.M. Knox (New York: Oxford University Press, 1967), 155-156.
} 
freedom of conscience, and the prudence never to practice either of them, ${ }^{, 42}$ noting that in the early years of the Federal Republic of Germany Germans were unable to uphold the third factor of this definition. Capturing his point, Voegelin writes: "If I harden myself with a particular idea and pursue only this goal, this one good, then in reaction there arises the counterstasis, the counterhardening, and with this the impossibility of social cooperation." ${ }^{\text {"43 }}$ Thus, according to Voegelin, post-war Germans, in their inability to effectively practice democracy, understood democracy only as a cliché. Insofar as they depend upon retaining a focus on humanity and individuals in society, the clichés of democracy and the state are bound together with certain anthropological principles.

Voegelin conceives of humanity as constituted by reason and spirit, taking the former from Greek anthropological formulations and the later from ancient Hebrew formulations. By means of the first, humanity seeks the divine as that mystery by which the world was established; and by means of the second, humanity encounters the divine in and through the world. In this sense, humanity "participates in the divine" through both nous (reason) and pneuma (spirit). ${ }^{44}$ Voegelin gives a great deal of significance to the notion of human participation in the divine. Again, in order to be a representative of society one must represent the transcendent realm, the divine, and in order to serve as a representative in this capacity one must also participate in the divine - that is, one must be grounded as a human by both reason and spirit. When one refuses or denies participation in the divine, Voegelin names this denial a dedivinizing of humanity. Moreover, "since it is precisely this participation in the divine, this being theomorphic, that

\footnotetext{
${ }^{42}$ Ibid., 84. The editors note: The actual quotation is "It is by the grace of God that in our country we have those three unspeakably precious things: freedom of speech, freedom of conscience, and the prudence never to practice either of them" (Joseph R. Conlin, ed., The Morrow Book of Quotations in American History [New York: McMorrow, 1984], 294).

${ }^{43}$ Voegelin, "Hitler and the Germans," 85.

${ }^{44}$ Ibid., 87.
} 
essentially constitutes man [sic], the dedivinizing is always followed by a dehumanizing. One cannot dedivinize oneself without dehumanizing oneself..." ${ }^{45}$ In both the dedivinization and the dehumanization, a loss of reality occurs. One closes oneself from the reality of the divine that constitutes humanity. Voegelin writes that such a loss of reality manifests itself negatively when humans replace the divine with themselves as that mystery by which the world came into being and as that which orients their acting in the world. Clearly, this type of replacement carries deleterious consequences, and Voeglin goes on to argue that precisely such a dedivinization and dehumanization occurred with Hitler when he was elected representative by the National Socialists in Germany.

One must note the difference between dedivinization in the lectures on Hitler and the Germans and in The New Science of Politics. In the latter, Voegelin defines dedivinization in conjunction with the Christianization of Rome as "the historical process in which the culture of polytheism died from experiential atrophy, and human existence in society became reordered through the experience of man's destination, by the grace of the world-transcendent God, toward eternal life in beatific vision." ${ }^{46}$ Here dedivinization takes place within Christianity and as a result of certain Christian motivations; it is notably not the result of a denial of Christianity. The replacement of a transcendent divine with the (theo)political institution of the church (now wed to imperial Rome) denotes the dedivinization that occurs with Christianity. In the lectures, dedivinization is not the result of moves within Christianity, though it is also not necessarily a move away from Christianity. In both regards, the process of dedivinization is the process of substituting a temporal (human) function or institution for the divine.

\footnotetext{
${ }^{45}$ Ibid.

${ }^{46}$ Voegelin, The New Science of Politics, 107.
} 
In the third lecture Voegelin describes Hitler explicitly as one suffering from the effects of dedivinization and dehumanization. Hitler's existence was not ordered by reason or spirit, as a result of Hitler's denial of human participation in the divine. Thus, a loss of reality followed in which Hitler's actions were no longer oriented to a transcendent divine, but to a temporal second reality serving as a stand-in for the lost first (transcendent) order of reality. "So reality and experience of reality are replaced by a false image of the divine. The [person], thus, no longer lives in reality, but in a false image of reality, which claims, however, to be the genuine reality."47 Voegelin notes the existence of these two realities, remarking that "normally ordered" humanity operates in the first reality, whereas those persons who are "pneumatically disturbed," or who no longer orient themselves in reason and spirit to the divine, operate in a second and false reality. Conflicts necessarily arise between the two because the first reality "indeed is not canceled by the fact that I make for myself a false idea of it and live according to it." ${ }^{, 4}$ These conflicts result in systems and lies. When one lives according to a second reality, one must formulate a system in which such a world operates, a new worldview out of which one can orient oneself in the (false) world. Additionally, since the second reality is a lie, the person living in a second reality has no choice but to proceed through incessant lying in order to explain away conflicts between one's second reality and the first reality or normally ordered humanity. In the case of Hitler (and other National Socialists), a system, a Nazi worldview, arose in order to legitimate a second reality, and lies in the form of propaganda and other concealments glossed over the blatant conflicts between this second reality and first reality. Voegelin strongly and succinctly summarizes the deleterious effects of this second reality when it forms its own worldview and becomes its own ideology in the final lecture: "If the second reality becomes

\footnotetext{
${ }^{47}$ Voegelin, Hitler and the Germans, 108.

48 Ibid.
} 
dominant in a society, there is indeed formally still a community made up of members of that society. But such a society perpetrates the highest betrayal of humanity. And in this kind of society anyone who is not alienated from the first reality can only commit high treason." ${ }^{49}$ His statement here stands as an accurate description of the function of second reality in Nazi Germany.

What does all of this have to do with the problem of mastery of the past? Since Voegelin himself does not return to the cliché of the unmastered past, it may seem we have gone rather far afield. However, I suggest that his analysis of first and second reality, brought about by a dedivinization and dehumanization, sheds some light on the drive to master the past as opposed to the desire to (appropriately) master the present. Contrary to how he sees other philosophers, historians, and political scientists proceeding after the fall of National Socialism, Voegelin does not engage in a recounting of the past or of the rise of Hitler for the purpose of obfuscation. Rather, he details the spiritual demise of Western society, which made possible Hitler's rise to power, as a means of demonstrating the problems that must be overcome or mastered in the present. Indeed, as Detlev Clemens correctly points out, Voegelin shows not only the spiritual demise of Hitler and other National Socialists, but also of the "better" Germans, such as Cardinal Faulhaber, Martin Niemöller, and Rudolf Bultmann, who took a clear and firm stance against National Socialism at the time of its ascension. He does this in order to demonstrate "the radicality of his thesis of Germany's deep intellectual and moral decline before, during, and still after the Nazi period." ${ }^{50}$ While for Voegelin the past is past and cannot be overcome, the problems that created and enabled the events of the past should be addressed and overcome; however, they remain to a large degree unresolved in the present. Insofar as the spiritual

\footnotetext{
${ }^{49}$ Ibid., 256.

${ }^{50}$ Clemens, 'Eric Voegelin's 'Hitler and the Germans' Lectures in the Context of the Germans' Treatment of Their Nazi Past," 16-17.
} 
deprivation that created the possibility for the rise of National Socialism remains unchanged, then mastery of the present will not be possible, and instead individuals wrongly focus on mastering the past.

Attempting to master the past, as Voegelin notes, obfuscates those aspects of society that lead to dedivinization, dehumanization, and ultimately a false representation that ushers in a second (and false) reality. If one then continues to operate out of this second reality, then conflicts with the first reality inevitably arise, as Voegelin has shown. The systematization and lies emerging as a result of the conflict, in an attempt to reconcile second reality to the first or to reify second reality as concrete reality over and above first reality, continue to legitimate themselves through attempts at mastery of the past. To reiterate Voegelin's claim in his discussion of the cliché of collective guilt, so long as one focuses upon a detailed recounting of the past, then examination of the past becomes an alibi for not addressing the problems of the past that remain in the present. Furthermore, as noted above, Voegelin argues that one's actions remain always under judgment by virtue of one's presence under God, and where such judgment does not occur, "the present is unmastered, and even if it sinks into the past, it remains still unmastered; and insofar as this worldly past influences the present in historical continuity, then also the contemporary present remains unmastered." ${ }^{51}$ Thus, Voegelin wishes to uncover an ethic that responds to demands present in the tension between the human and the divine, in the metaxy. Attempts at dedivinization gloss over this tension and keep such an ethic from becoming clear. Only by following this ethic imposed as a result of one's presence under God can one succeed in mastering the present.

${ }^{51}$ Ibid. 


\section{Mastery of the Present and Critical Self-Reflection}

One can perceive an undeniably theological tone to Voegelin's assertions, a tone that results from his own Christian background, from his Western philosophical background, and from his recourse to Platonic philosophy. Unlike Adorno, Voegelin is not Jewish, but Christian. While his work after the rise of National Socialism includes a strong critique of Nazi racism and anti-Semitism, he arrives at this critique from a very different place than Adorno. For Voegelin, Nazi racism is anathema to the idea of universal humanity that he hopes will be realized in the world. Consequently, he draws from some of the philosophical and theological assumptions that Adorno might view as requiring transformation after Auschwitz, such as traditional approaches to revelation and the transcendent divine. Indeed his philosophical underpinnings are sometimes at odds with Adorno's work and sometimes find resonance with it. As I suggested at the end of the previous chapter, certain similarities exist between the notions of mastery of the present and critical self-reflection. Yet one cannot simply harmonize the two conceptions, since the two thinkers arrive at these ideas by rather divergent means. The ability to master the present for Voegelin is predicated upon a certain anthropology that includes the notion of humanity as participating in the divine, whereas Adorno's critical self-reflection as a process of working upon the past derives from psychoanalytically based views of subjectivity. This basic difference illuminates additional divergences between these thinkers.

First, Voegelin's understanding of judgment in the world as a result of one's presence under God results in or points to a universal humanity and universal ethic. Alternatively, Adorno's new categorical imperative (also itself a universal ethic) appeals to the experience of human suffering and the adverse conditions of material reality without orienting itself to a notion of the divine or the transcendent. Voegelin might well (and rightly) see Adorno's ethic as the 
result of a secularizing worldview founded in historical materialism and psychoanalysis rather than any transcendent reality, while Adorno might remain skeptical of a universalizing principle that claims its origination in the divine.

Second, and similarly, for Voegelin reason and spirit constitute humanity. Again, we see here how participation in the divine maintains a significant function in Voegelin's philosophy. The human is grounded in reason (nous) and spirit (рnеuma) insofar as she or he realizes her or his participation in a transcendent sphere and existence in a world that comes about from a power beyond oneself. For Adorno and Horkheimer, on the other hand, self-reflection establishes subjectivity. The ability to consciously examine oneself as a subject and view others as subjects outside of oneself (without recourse to reification or objectification) constitutes the human subject. As noted in the previous chapter, the conscience is grounded in its ability to view something external to itself, such as another subject, as substantial and worthy of one's own concern; and this occurs outside any mention of the divine or of one's being as grounded in something infinite beyond oneself. I will say much more about the theological implications of both Voegelin and Adorno in the final section of this work, but for now let us simply note the tension between Voegelin's appeal to a transcendent God as the orienting principle for human existence, action, and political representation and Adorno's more secularized view of human subjectivity as grounded in conscious self-reflection. More work must be done in order to decide whether or not Adorno would necessarily disagree with Voegelin's theological undertones (and it is to this work that we will turn in subsequent chapters), but we can clearly state that such concepts are not present in Adorno's writings on the problem of working through the past.

Despite these crucial differences, I suggest there is a great deal of resonance between their respective critiques of the problem of coming to terms with the past. For both, the 
unmastered past becomes a cliché, a modish slogan bandied about in popular and political rhetoric with little thought as to the consequences of such a mastery. Likewise, both relegate the concept of collective guilt or the guilt complex to the status of cliché since it too results in a failure to deal with the past at all, precipitating instead either an effacement of the past or a mere recounting of the events of the past. In addition, Voeglin's mastery of the present ultimately comes strikingly close to Adorno's critical self-reflection. Each requires self-reflection and a return to the subject or to a basic anthropological understanding. Indeed, mastery of the past versus mastery of the present can be viewed as roughly analogous to working through the past versus working upon the past. Voegelin and Adorno both note the way in which the former only attempts to gloss over the past, while the later involves the sort of self-reflection that uncovers the underlying problems of the past that continue to exist in the present.

As I move toward constructing a theology of remembrance, Voegelin's and Adorno's conceptions of mastery of the present and critical self-reflection will serve as guides for how one might effectively and appropriately address the deleterious past of the Holocaust. Seeking the underlying problems out of which the harmful past emerged sheds some light on how to live in the present and future, though it does not overcome the past or place the past securely behind us. In Part II we will turn to Whitehead's speculative philosophy as a means for theorizing how this process may be viewed from a metaphysical standpoint, but first we will examine Adorno's warnings against metaphysics (or against a certain kind of metaphysics) in order to proceed cautiously, lest we fall into the same trap as those who Voegelin critiques as setting up second realities complete with systematization and lies over against first, lived reality. 


\section{Chapter 3: Metaphysics After Auschwitz}

From the previous chapter on Voegelin's argument against mastery of the past, we can begin to imagine the problems inherent in traditional metaphysical systems insofar as they attempt to master the past or come to terms with the past by providing metaphysical answers to the problems of lived reality. Recourse to metaphysical reflection as a means of clearing away the past or solving the problems of the past by synthesizing it into an elevated metaphysical concept has been strongly criticized by both Voegelin and Adorno. This chapter will deal chiefly with Adorno's critical reflections on metaphysics, which result in his own version of the dialectic that refuses to endow every moment of experience with positive meaning. In order to elucidate the significance of this critical engagement with metaphysics in relation to the problem of coming to terms with the past, I will begin with a lengthy quotation from Adorno's lectures on metaphysics:

The desire for the existing culture to be swept away and an absolutely new start to be made has been very strong in Germany since the catastrophe. And I believe that the question of the position of metaphysics today has much to do with this desire - in that there has been a belief that, if only the debris of this culture could be finally cleared away, access could be gained to the original truth to which metaphysics points and which, according to this view, has been merely concealed by culture. ${ }^{1}$

There are two problems here to which Adorno points. First, as demonstrated through Adorno and Voegelin above, clearing away the debris or effacing the deleterious past results in far more harm than good, since such a move refuses to examine the causes of the problems of the past (which all-too-often still manifest themselves in the present). Second, the original truth toward which Adorno notes a strong appeal could well be caught up in the causes of harmful events of the past and not in their solution. Hence, Adorno saw it as necessary to rethink metaphysics in

\footnotetext{
${ }^{1}$ Theodore Adorno, Metaphysics: Concepts and Problems ed. Rolf Tiedemann, trans. Edmund Jephcott (Standford, CA: Stanford University Press, 2000), 127.
} 
an effort to avoid any clearing away or mastery of the past and to provide a needed critique of systems that appeal to an original truth which might overcome the refuse and excrement of the world through its synthesis into an elevated concept. In what follows I will examine Adorno's lectures on metaphysics and his reflections on metaphysics after Auschwitz in order to understand precisely what form of metaphysical reflection (if any) remains tenable after the events of the Holocaust. In doing so, I am attempting to establish both a critique of traditional metaphysics (from the tradition of Aristotle and extending through the metaphysics of Hegel) as well as a means for reading Whitehead's speculative philosophy as a viable option even after Auschwitz.

In the summer of 1965 Adorno gave a series of lectures at the University of Frankfurt entitled "Metaphysics: Concept and Problems," later collected and published by Rolf Tiedemann and Edmund Jephcott. These lectures draw significantly from versions of his manuscript for Negative Dialectics, published the following year. In fact, as Tiedemann notes, Adorno gave the latter portion of the lectures (lectures thirteen through eighteen) extemporaneously from his notes or pieces of the manuscript comprising the last section of Negative Dialectics, entitled "Meditations on Metaphysics." Thus, there is strong correlation between the two works, as I will highlight in the course of this chapter. In both, Adorno gives the forceful injunction that metaphysical reflection must not continue unaltered after the events of Auschwitz. In this chapter I will explicate the reasoning behind this injunction and suggest that metaphysical reflection for Adorno becomes the oscillation between metaphysical statements and their critique.

\section{The Failure of the Enlightenment}

While clearly a skeptic of the possibility of doing metaphysics after Auschwitz, Adorno was also no stranger to the metaphysical tradition ranging from Aristotle to Heidegger. In his 
lectures, Adorno provides a thorough explication of Aristotelian concepts of form and matter, of reality and potentiality, bringing such concepts into conversation with Kant, Hegel and Heidegger. At the outset of the first lecture he names metaphysics the "vexed question of philosophy," ${ }^{2}$ noting also "it is very difficult to say what metaphysics actually is." ${ }^{3}$ Throughout the lectures he posits numerous various definitions of metaphysics, beginning with metaphysics as "the form of philosophy which takes concepts as its objects." In other words, metaphysics deals with the realm of concepts, which (in his analysis, and in the traditional usage) is decidedly distinct from the realm of existence. He writes that these concepts are almost always elevated into higher orders of being over existing things. It is this elevation of concepts which Adorno finds problematic, and thus within his first lecture he highlights the subtitle of the lecture series- "concepts and problems"-indicating that he will not only discuss the concepts of metaphysics, but will also critically address the troubling notions that he sees inherent in metaphysical reflection, particularly as they relate to $20^{\text {th }}$ century concerns. Indeed, while his writings and lectures display an acute understanding of the history of philosophy, Adorno-from his work with Max Horkheimer in Dialectic of Enlightenment to his last major work, Negative Dialectics — strongly and poignantly critiques metaphysics.

The first reports of the death camps in Germany and Eastern Europe reached Adorno and Horkheimer as they were in the process of writing Dialectic of Enlightenment. This news reshaped their understanding of the European Enlightenment and caused them to cite it as an ultimately failed project. While they set out to examine the meaning and effects of the Enlightenment, after learning of the atrocities of Auschwitz and the other camps they were forced to grapple with the question of "why humanity, instead of entering a truly human state, is

\footnotetext{
${ }^{2}$ Ibid., 1.

${ }^{3}$ Ibid.

${ }^{4}$ Ibid., 4.
} 
sinking into a new kind of barbarism." ${ }^{5}$ For Adorno and Horkheimer, the project we have come to know as the European Enlightenment failed, and failed tragically. The rationality that gave birth to the philosophical systems in which every aspect of reality was endowed with positive meaning was and is simply no longer tenable. The barbaric acts of the First and Second World Wars, and especially the Holocaust, pointed to the collapse of Enlightenment civilization. Thus, for he and Horkheimer, the continued attempt to assign meaning to such barbaric events seemed absurd. As Rolf Tiedemann comments on the premise of Dialectic of Enlightenment, 'Philosophy, which, according to Hegel, is 'its own time comprehended in thoughts,' has failed abysmally in its efforts to comprehend the rupture that civilization has experienced, let alone to give it any 'meaning.",6 The metaphysical systems of Aristotle, Hegel, and Heidegger have failed, and we are left only with the absurdity of attempting to apply meaning to horrendous events such as those experienced in Europe during the war.

The opening lines of Dialectic of Enlightenment indicate the trajectory of the book and of Horkheimer and Adorno's thought: “Enlightenment, understood in the widest sense as the advance of thought, has always aimed at liberating human beings from fear and installing them as masters. Yet wholly enlightened earth is radiant with triumphant calamity."7 Despite the advance of thought, despite (or perhaps because of) the fact that human beings have been installed as masters in a demythologized, de-animated world, the enlightened world collapsed

\footnotetext{
${ }^{5}$ Theodore Adorno, Gesammelte Schriften ed. Rolf Tiedemann, et al. (Frankfurt am Main: Suhrkamp, 1970-87), 3:11; quoted in Rolf Tiedemann, "Not the First Philosophy, But a Last One': Notes on Adorno's Thoughts," Introduction to Can One Live After Auschwitz?: A Philosophical Reader ed. Rolf Tiedemann, trans. Rodney Livingstone and others (Stanford, CA: Stanford University Press, 2003), xii.

${ }^{6}$ Rolf Tiedemann, "'Not the First Philosophy, But a Last One': Notes on Adorno's Thoughts," Introduction to Can One Live After Auschwitz?: A Philosophical Reader ed. Rolf Tiedemann, trans. Rodney Livingstone and others (Stanford, CA: Stanford University Press, 2003), xiii.

${ }^{7}$ Max Horkheimer and Theodor Adorno, Dialectic of Enlightenment: Philosophical Fragments, ed. Gunzelin Schmid Noerr and trans. Edmund Jephcott (Stanford, CA: Standford University Press, 2002), 1.
} 
into totalitarianism and, as Adorno insists, barbarism. ${ }^{8}$ The first section of Dialectic of

Enlightenment describes the Enlightenment as a voracious machine sucking up anything that diverged from rational thought or from the emerging economic and political systems. Anything outside rationality, anything that smacked of superstition, myth, or supernaturalism was to be feared or, at best, treated with supreme distrust. "For enlightenment, anything which does not conform to the standard of calculability and utility must be viewed with suspicion." ${ }^{\prime 9}$ To overcome the animism and mythology of pre-Enlightenment thought, Adorno and Horkheimer assert that the Enlightenment read enlightened thought back into the myths of by-gone generations. The myths themselves served as narratives of origins, explanatory stories unfolding the hidden meanings and workings of the universe, and enlightenment thinking endowed them with rationality. The Enlightenment so usurped mythology as to completely subsume and devour it in the name of rational thought; however, in so doing, Adorno and Horkheimer suggest that Enlightenment, in a twist of irony, simply replaced the old myths with itself. Enlightenment became the new mythology:

Mythology itself set in motion the endless process of enlightenment by which, with ineluctable necessity, every definite theoretical view is subjected to the annihilating criticism that it is only belief, until even the concepts of mind, truth, and, indeed, enlightenment itself have been reduced to animistic magic. ${ }^{10}$

\footnotetext{
${ }^{8}$ Adorno frequently notes this descent into barbarism; the word appears in Dialectic of Enlightenment and in "Education After Auschwitz". While Adorno (and Horkheimer) were quite willing to describe Nazi Germany as a return to barbarism, others remained rather put off by the term. Voegelin takes his critique of the enlightenment project in a different direction by suggesting that the growing secularization of life brought with it the possibility for radical, anti-Christian, quasi-religious movements (such as National Socialism). He understood use of the term barbarism as bound together with a subtle critique of the pre-Enlightenment religious world, and such usage was anathema to his own project of articulating a re-orientation of the world under a transcendent guiding principle. While he and Adorno disagree on the appropriateness of naming National Socialism a "regression to barbarism," their critiques of the Enlightenment are actually quite similar, as both approach with suspicion the rational and radical de-mythologization of the world and the desire for secular sameness. Cf. Erich Voegelin, Political Religions, trans. T.J. DiNapoli and E.S. Easterly III (Lewiston, NY: Edwin Mellon Press, 1986), 2.

${ }^{9}$ Dialectic of Enlightenment, 3.

${ }^{10}$ Ibid., 7.
} 
While the Enlightenment saw itself as a progression past mythological thought and animistic symbolisms, it resulted largely in a regression back to ubiquitous myth. The title "Dialectic of Enlightenment" thus means precisely this dialectical movement between progress and regression. "The curse of irresistible progress is irresistible regression." 11 As much as the Enlightenment led to progress through the advent of the scientific method, the development of mathematics, and the flourishing of rational thought, it equally led to regression by inculcating a fear of that which remained (or was seen to remain) outside rational thought, by abolishing subjectivity in favor of mechanisms of order, and by installing itself as a sort of totalitarianism over and above other modes of thought. It is with this background that we approach Adorno's lectures on metaphysics, already aware of the suspicion with which he treated the prevailing worldview under which Kantian transcendentalism and Hegelian metaphysics developed, and already aware of the sense in which enlightenment thought replaced old mythology with itself. For, as he notes in his first lecture, "it is undeniable that metaphysics itself is a phenomenon of the secularization of mythical and magical thinking, so that it is not so absolutely detached from superstitious ideas as it understands itself to be, and as it has presented itself in the history of philosophy." "12

\section{Aristotle and the Logic of Form}

Adorno's lectures on metaphysics begin with a return to Aristotle. In fact, the entire first half of these lectures deals almost exclusively with Aristotelian concepts, occasionally bringing them into conversation with Enlightenment and post-Enlightenment metaphysical philosophy. He offers the thesis in lecture three that metaphysics began with Aristotle, arguing this on the grounds that if metaphysics begins where one takes up the tension between the empirical world and the world of ideas, the "supra-sensible world," then Aristotle's endeavor to correlate the two

\footnotetext{
${ }^{11}$ Ibid., 28.

${ }^{12}$ Metaphysics, 3.
} 
marks its point of entry. In order to support this statement, Adorno draws comparisons between Aristotle's metaphysics and Plato's earlier notions of Ideas and Forms. First, he notes that for Aristotle (and contra Plato) the universal is not something "existing in and for itself,"13 but is only a universal by means of its inherence in a particular. Moreover, "the point of Aristotle's Metaphysics is that while, on the one hand, one cannot think of the universal independently of that in which it is concretized, on the other hand, it is not a mere abstraction in relation to the particulars subsumed under it." ${ }^{14}$ In this regard, Aristotle goes beyond Plato's supposition of a realm of Ideas (or universal concepts) as separate from concrete, real "things." Yet, despite Aristotle's correlation of the empirical with that which is beyond sense perception, the connection between form and matter, Adorno presents Aristotle as establishing the foundation for both a strong dualism and a robust idealism, each of which he sees as antithetical to the problems that arose in the $20^{\text {th }}$ century.

Adorno notes repeatedly that the key to understanding Aristotle's Metaphysics lies in remembering that form (the universal concept) is the real, while matter is mere possibility. Recognizing this as somewhat counterintuitive, he writes: "To state the position paradoxically, reality in Aristotle's philosophy corresponds to what we call possibility, and possibility to what we call reality."15 Undoubtedly, the universal or form remains the higher reality and the really real; however, without sensible matter, one cannot know the form. Apart from its existence in matter, we have no knowledge of form qua form, of form as abstract concept. Nevertheless, it is form that is substantial, rather than matter, because matter without form "is stripped of all determinateness," is entirely empty. ${ }^{16}$ Moreover, the substantial must be that which needs

\footnotetext{
${ }^{13}$ Ibid., 25 .

${ }^{14}$ Ibid.

${ }^{15}$ Ibid., 37.

${ }^{16}$ Ibid., 61 .
} 
nothing else in order to exist, and therefore can only be form, or the universal. "Matter," in contrast to form, "is defined as mere possibility or potentiality, because it must always have within it the possibility of attaining such reality, of attaining its form..."17 Such distinction between form and matter, despite the apparent intertwinement of the two, results in a stark dualism, according to Adorno. Form remains always the higher concept, the real, while matter without form is void, mere possibility with no actuality. To trace this dualism further, Adorno introduces Aristotle's principle of change. Matter is not static, but rather is in constant flux; it changes according to the form inhering in it. Form, on the other hand, remains changeless, eternal. From this notion we arrive at the concepts of the mover and the moved. Adorno suggests that in Aristotle wherever form and matter come together there must be movement, since change occurs on the part of matter as a result of taking on certain forms-hence a movement from nothing (pure potentiality) to something or from one thing to another. Therefore, form became associated with the mover and matter with the moved. Aristotle developed an ontological anthropology based on the notions of mover and moved by claiming that the human contains within itself both the moving principle, as the higher and spiritual principle, and the moved, or the material principle. Adorno thus insists that the "whole later dualism of substances, of body and soul...was formulated for the first time, and in all its trenchancy, in this ontological anthropology, which divided the human being itself into a moving principle and a moved, material principle." 18 Beyond the legacy of body/soul dualism, the principle of the mover and the moved further led to theological developments based upon an understanding of God as the prime mover, the unmoved mover.

\footnotetext{
${ }^{17}$ Ibid., 63.

${ }^{18}$ Ibid., 83.
} 
Since not only form and matter, but also the relationship between the two are eternal, Aristotle holds that movement is eternal- "movement can never have begun and can never cease. ${ }^{, 19}$ Yet, attempting to avoid an infinite regression, he posits that there must have been something immobile (and also itself eternal) which stands as the ultimate reason for this movement. Hence, the unmoved mover- "And with this concept we have made the transition from Aristotelian metaphysics to what might perhaps be called Aristotelian theology." ${ }^{20}$ The unmoved mover must be form without matter, pure actuality without potentiality, since for Aristotle form denoted perfection and matter imperfection (and from this medieval theology derived its principle of God as actus purus, pure act). Concluding his remarks on Aristotle's unmoved mover, Adorno summarizes: "The ultimate ground of all movement, therefore- to state the matter in Aristotelian terms - is the divinity itself as pure and perfect mind or spirit (Geist). Its activity—so Aristotle's argumentation runs—can only consist in thought.." ${ }^{21}$ Thus, the legacy of Aristotle's unmoved mover became the conception of God as thought thinking itself, as pure mind or spirit (overtly alluding to Hegel). Adorno, however, names this sort of eternal self-reflection on the part of the divine as a sacrifice of the empirical- "through this very contentment with his own self-contemplation, God abandons the world.".22 If, as in Aristotle's metaphysics, the world moves always toward the absolute and yet the absolute does not act on the world (since here the absolute is pure actuality, pure form without matter), then such an abandonment of the world seems clear. Here we witness a critique of Aristotle not only on metaphysical grounds, but also on theological grounds, since the inverse theology the Adorno attributes to his and Benjamin's thought decidedly refutes any notion of a transcendent God

\footnotetext{
${ }^{19}$ Ibid., 87.

${ }^{20}$ Ibid., 88.

${ }^{21}$ Ibid., 91 .

${ }^{22}$ Ibid., 95.
} 
uninvolved with the material (reality). Thus, in the end, Aristotle too leaves behind the empirical in favor of the supra-sensory, the absolute as pure actuality, by arguing that all of existence moves toward this One as the highest good (and Adorno seems to offer the same critique of Hegel). His exposition of Aristotle ends with the following cautionary statement: "Traditional philosophy gives us serious grounds to mistrust it, I believe, whenever it resolves everything into one, into identity, in a kind of grand finale, since it thereby forgoes the very concreteness which its results ought to have.",23

\section{Metaphysical Reflection and Temporal Existence}

In the middle of lecture thirteen an abrupt shift occurs as Adorno ends his explication of Aristotelian metaphysics and begins to address the crisis of metaphysics in the $20^{\text {th }}$ century. The reality of the Holocaust ushered in a profound change in Adorno's thinking regarding the ability of metaphysics to account for the experiences of temporal existence. Marking his transition in lecture thirteen, Adorno considers "the possible status of what might be called metaphysical experience today," 24 the meaning of which he unfolds through the course of the subsequent lectures. He admits straightforwardly his own dialectical tendencies (having been influenced by the left-wing Hegelians) and uses the dialectical method to critique Aristotelian metaphysics and, in fact, any metaphysics that holds "that the immutable is true and substantial while the transient is inferior and despicable, a mere mode or deception of the senses..." ${ }^{25}$ Here we come to the crux of the matter: "If we start from an awareness that, for us, the equation of the immutable with the good, the true and the beautiful has been simply refuted, then the content of metaphysics is

\footnotetext{
${ }^{23}$ Ibid., 96.

${ }^{24}$ Ibid., 100.

${ }^{25}$ Ibid., 100.
} 
changed. ${ }^{26}$ Adorno will no longer tolerate a metaphysical dualism in which the changeless forms are conceived as a higher reality than temporal matter, than the empirical events of transient life. Only with this fundamental shift can he begin to address the problems of the $20^{\text {th }}$ century as they relate to metaphysical experience.

Adorno is clear in stating that the realm of ideas, the immutable concepts, can no longer be separated in philosophical discourse from the experiences of lived reality. He arrives at this statement because of recent experiences in the temporal world, remarking that, "[i]n light of what we have experienced in our time...these experiences, I say, change the content of metaphysics." ${ }^{27}$ The temporal experiences of the victims of the Holocaust (and for Adorno, the experiences of those who survived and who now question their right to go on living) simply do not square with a system of concepts that would remain isolated from such experience. Any metaphysical system or reflection must now account for these experiences by "assimilating" the temporal into the concept, realizing that a separation of the two in the first place was merely arbitrary and perhaps even false. ${ }^{28}$ This assimilation then requires that the very idea of metaphysics be radically changed.

For Adorno, Auschwitz becomes a sign indicating "not only Auschwitz but the world of torture which has continued to exist after Auschwitz and of which we are receiving the most horrifying reports from Vietnam. ${ }^{, 29}$ He explicitly tells his students that the word symbol would not suffice, since Auschwitz must be viewed as the symbol of all symbols. Beyond Adorno's refusal to use the word symbol, I suggest that symbol fails in this context because Auschwitz does not point toward a more abstract concept - it cannot be taken as a material marker to denote

\footnotetext{
${ }^{26}$ Ibid., 100.

${ }^{27}$ Ibid.

${ }^{28} \mathrm{Ibid}, 101$.

${ }^{29}$ Ibid.
} 
an abstraction, but rather is the material signpost pointing to an historical rupture, a fundamental alteration in the world of material reality. The sign of Auschwitz becomes for Adorno a caution, a warning against proceeding with "metaphysics as usual," as one might say. The practice of metaphysical reflection, of positing a philosophical system that accounts for being, has been shaken to the core. Adorno voices his warning explicitly and forcefully (and I will quote him at length in order to deliver the full force of his rebuke):

Those who continue to engage in old-style metaphysics, without concerning themselves with what has happened, keeping it at arm's length and regarding it as beneath metaphysics, like everything merely earthly and human, thereby prove themselves inhuman. And the inhumanity which is necessarily present in such an attitude must also infect the concept of a metaphysics which proceeds in this way. ${ }^{30}$

Returning to the Platonic and Aristotelian correlation of the immutable and the good, he again reminds his audience of the impossibility of continuing to endow every aspect of being with positive meaning. As he and Horkheimer had already begun to suggest in Dialectic of Enlightenment, such a supposition in the face of the victims of Auschwitz would be not only absurd, but entirely inhuman - "a pure mockery in the face of the victims and the infinitude of their torment." ${ }^{, 31}$ In both Metaphysics and Negative Dialectics, he reminds the reader of Voltaire's experience of the Lisbon earthquake and his inability thereafter to hold on to the philosophy of Leibniz in which this world must be the best of all possible worlds. Drawing his own comparison, Adorno likewise sees Auschwitz as the event that shattered the Weltanschauung that grew out of the Enlightenment. The Hegelian dialectic of world history has come crashing down. No longer can one in any sense regard the course of history as rising continually in a positive progression, much less toward any eternal perfection. He writes: "there can be no one, whose organ of experience has not entirely atrophied, for whom the world after

\footnotetext{
${ }^{30}$ Ibid.

${ }^{31}$ Ibid., 102.
} 
Auschwitz, that is, the world in which Auschwitz was possible, is the same world as it was before. ${ }^{.32}$ The world must be viewed differently after Auschwitz—indeed, the world is different after Auschwitz. And so philosophy must also undergo a radical change.

As mentioned in chapter one, Adorno cites a new categorical imperative, given to us by Hitler, "that, quite simply, Auschwitz should not be repeated and that nothing like it should ever exist again. ${ }^{33}$ Like Kant's categorical imperative, this imperative has no recourse to logic, no foundation in rationality. Again, rationality failed humanity in the form of the collapsed project of the Enlightenment. Rationality did not guard against the atrocities committed under National Socialism, but rather aided in their unfolding. However, to be sure, Adorno likewise does not state this imperative from any irrational basis (and he is quite clear to say as much), nor does it come from any transcendent moment or appeal to theological motifs (unlike Voegelin's ethical mandate in the presence under God). Rather, it is thoroughly grounded in precisely that which has been omitted from traditional metaphysical reflection - material reality. Thus, the new categorical imperative is both a moral-philosophical statement as well as a metaphysical statement, providing further impetus to avoid those metaphysical systems that fail to regard temporal existence as worthy of reflection or as something other than the despicable realm assigned to it by Aristotle and the philosophical tradition extending from Aristotle. As a metaphysical statement it "can find its justification only in the recourse to material reality, to corporeal, physical reality, and not to its opposite pole, the pure idea." ${ }^{34}$ The result of this is that "[m]etaphysics, I say, has slipped into material existence."35 The other side of this imperative (if there can be two sides to moral imperatives) can be stated as such: that no metaphysical

\footnotetext{
${ }^{32}$ Ibid., 104.

${ }^{33}$ Ibid., 116.

${ }^{34}$ Ibid., 117.

${ }^{35}$ Ibid.
} 
reflection any longer ignore the suffering of material reality. Metaphysics, as Adorno writes, may not ignore the "carrion, stench, and putrefaction," inherent in material reality lest it risk "itself becoming something just as thin, untrue and wretched." ${ }^{36}$ Instead, metaphysical reflection must be done precisely from this place of putrefaction, from the rubbish heap.

Because culture has not lived up to this imperative, nor to the metaphysical side of the imperative, which I have articulated, Adorno believes that culture has failed- - "philosophy, art and rational science have not really impinged on human beings, to whom they are necessarily addressed as their ideal subject. ${ }^{, 37}$ Instead of responding to and reflecting on material existence after Auschwitz, culture simply returned to its previous modes of expressing the transcendent qualities of truth, beauty and goodness. Adorno calls this the resurrected culture, which he also names as the very refuse from which culture itself tried to escape. Thus, we return full circle to the statements quoted at the beginning of this chapter regarding the desire to sweep away the ruins in order to return to a previous point in which metaphysics offered answers to the questions of human existence and in which something we might term original truth seemed readily at hand. Reminding us of the futility of such a project, Adorno writes: "This resurrected culture resembles the ruins it has cleared away; having removed them it then reinstalled itself on them in the wretchedly makeshift way which is symbolically revealed by the outward image of our rebuilt cities. ${ }^{, 38} \mathrm{He}$ turns to a discussion of culture in his lectures on metaphysics because, as he notes, questions of culture and questions of metaphysics are intertwined. This stands very much against any notion of metaphysics as a discussion of certain transcendent truths that have no apparent or actual relationship to the historico-cultural situation, the "situatedness" in which people find themselves in lived reality. Rather, what happens and what has happened in the

\footnotetext{
${ }^{36}$ Ibid., 117.

${ }^{37}$ Ibid., 118.

${ }^{38}$ Ibid., 119.
} 
events of human existence directly affect the metaphysical answers or responses given to questions about how such events could have occurred. Adorno states his position on the matter quite clearly:

I believe, in other words, that the metaphysical thesis of the inherent meaning of the world, or of a cosmic plan underlying everything which happens, must be called into question at the very moment when a meaningful connection can no longer be established between what has happened and the metaphysical ideas. ${ }^{39}$

As a consequence of this, the traditional attribution of positive meaning to the events of the past, namely Auschwitz and all that Auschwitz entails, becomes simply blasphemous. ${ }^{40}$

There no longer remains any possibility in Adorno's mind of a recourse to an absolute or to transcendent ideas as a metaphysical response to the barbarism into which the Western world fell during the twentieth century. One corollary of this is the denunciation of any theodicy in the face of the Holocaust, and a second, which is tied to the first, Adorno names as the inability to continue using the noble, elevated, sublime words of traditional philosophy. Regarding the first, Adorno echoes the thought of Emmanuel Levinas ${ }^{41}$ as he cites not only the utter failure, but also the complete absurdity of any theodicy in light of the events of the Holocaust. For Adorno the reliance upon theodicy places demands upon the absolute, upon God, which "effectively demonizes the absolute." ${ }^{2}$ Theology, Adorno writes, was never good at accounting for such atrocities, but when the prevalence of these evils became such that they could no longer be ignored, this pointed to the complete failure of theodicy. Any notion of the absolute, therefore, that attempts to answer the question of why these things have happened can only express a complete incommensurability between the absolute itself and the reality in which such events

\footnotetext{
${ }^{39}$ Ibid., 121.

${ }^{40}$ Ibid.

${ }^{41}$ In "Useless Suffering” Levinas writes that "The disproportion between suffering and every theodicy was shown at Auschwitz with a glaring, obvious clarity." I will further unpack and exegete Levinas's position in chapter seven. For "Useless Suffering," see The Provocation of Levinas, ed. Robert Bernasconi and David Wood (New York: Routledge, 1988), 158-167.

${ }^{42}$ Metaphysics, 121.
} 
occur. Dialectical theology (and Adorno cites Barth specifically) failed because it refused to admit culture into its account. The dialectical theologians following $\mathrm{Hegel}^{43}$ viewed with derision the "intertwinement" of cultural and metaphysical ideas, preferring an appeal to an absolutely other, an entirely transcendent other, in favor of any possibility that metaphysical ideas would comingle with culture. ${ }^{44}$ The result of this derision is the inevitable retreat to theodicy in which the absolutely other answers for the evils of the world. Now, however, the very divorce of culture from metaphysics itself becomes evil. Despite the fact that Adorno cites culture as having failed, one must nevertheless refrain from abandoning culture completely in favor of notions of the absolute, transcendent ideal. This critique of theodicy will be repeated, by way of Whitehead, Roland Faber, Richard Rubenstein, Emil Fackenheim, and Emmanuel Levinas, in the last three chapters.

The second consequence of denouncing any possible recourse to an absolute as a metaphysical response to Auschwitz is the inability to continue using the sublime words of traditional philosophical reflection. Adorno's reason for this is twofold: first, “lofty words have become simply incommensurable with experience," and second, these lofty, sublime words have all already been appropriated by the totalitarian regimes and have been used in the name of the evils they have perpetrated. ${ }^{45}$ What we find here in Adorno bears similarities to Voegelin's statement that certain phrases and certain philosophical terms have been taken over by ideologies and, therefore, have taken on new, and sometimes perverse, meaning. While Voegelin asserts that terms such as the conditio humana or nous and pneuma have been ideologized, Adorno takes the assertion a step further by claiming that the elevated concepts of philosophy have been

\footnotetext{
${ }^{43}$ While Barth is a prime suspect in this category, Tillich must be excluded, since he initiated and promoted a dialectic between the metaphysical ideas and the temporal, cultural situation.

${ }^{44}$ Metaphysics, 122.

${ }^{45}$ Ibid., 123.
} 
usurped by totalitarian regimes and redeployed in the name of the atrocities committed by these regimes. Not only have they been ideologized, but they have also become demonized. "It is practically the trademark of totalitarian movements that they have monopolized all the so-called sublime and lofty concepts, while the terms they use for what they persecute and destroy—base, insect-like, filthy, subhuman and all the rest- they treat as anathema. ${ }^{, 46}$ As a result, Adorno maintains that these sublime words and concepts can no longer be used, especially not to account for the horrific events committed by the very regimes that have usurped them. Rather, a reappropriation must occur in which the despicable words used to describe those persons and ideals which the regimes sought to destroy become the very words of metaphysical reflection. This call for metaphysics to become philosophical reflection on the very refuse, the rubbish heap of history, will be explored in detail below.

In his seventeenth lecture, Adorno summarizes his critique of metaphysics in the twentieth century. Following from his comments on the failure of theodicy and the inability to continue using the sublime words and concepts, he tells his students that the metaphysical systems in use at the time of the lectures attempt to institute themselves as a substitute for the critical reflection actually necessary in order to avoid a retreat to the absolute or transcendent, and away from the refuse with which one should really concern oneself. He writes: "what is most deeply suspect in the popular metaphysical systems of today is that they always convey the message, even if peripherally and as if from far off, that things are not really so bad." ${ }^{, 47}$ Adorno maintains that philosophical reflection must not be employed to cover over the past or to conceal the atrocities of the past and present, nor should metaphysics attempt to justify or account for the continuation of horrific acts.

\footnotetext{
${ }^{46}$ Ibid., 123.

${ }^{47}$ Ibid., 133.
} 


\section{The Remains of Metaphysical Reflection}

Rather than simply denouncing/renouncing philosophical reflection and metaphysics

altogether, Adorno attempts to unfold an understanding of philosophy after Auschwitz that might "save" philosophy from impending failure. While Adorno turns full force to this altered version of metaphysics or philosophical reflection in the last lecture of his lectures on metaphysics, he has given hints of it throughout the lectures. The final section of this chapter will trace these glimpses along with his remarks in lecture eighteen while also examining his work in Negative Dialectics as a reworking or reformulation of metaphysics after Auschwitz. By way of a methodological note, I contend that Metaphysics and Negative Dialectics, while existing as separate works, cannot be separated in terms of their content, since the lectures were presented largely from notes that soon became the manuscript for Negative Dialectics. Thus, we have a messy chronology that prohibits us from simply moving from one text to the next, as if there were a continual development from one to the other. This section, therefore, will move between the two texts, rather than attempting a formal transition from Metaphysics to Negative Dialectics.

In lecture eighteen Adorno begins to describe that which he has elusively termed metaphysical experience. Metaphysical experience, he writes, must be fallible. Taking, for a moment, the side of the empiricists, he explains that since experience is not bound up with concepts it could either fall into one's lap or it could not. One has no guarantee that one will have an (metaphysical) experience of a particular event or no guarantee as to how one will receive this experience. Adorno seems to speak of experience as a cognitive, measurable moment within the psyche of the subject, and therefore fallibility becomes a condition of psychological receptiveness to various experiences. Moreover, other factors within one's psyche invariably determine how one receives these experiences, particularly those that are "the weakest and most 
fragile experiences, ${ }^{, 48}$ — hence the fallibility of metaphysical experience and the possibility that a particular experience might "miss the mark, that it can be quite wrong...",49 Only that experience which contains this fallibility can be metaphysical experience, as opposed to the scientificrational moments of experience that cannot be refuted and that aren't really worthy of being reflected upon in the first place. The only important experiences are these fallible experiences, and it is worth reflecting on these experiences precisely because they might be refuted. Additionally, and perhaps more importantly, these metaphysical experiences are experiences of lived reality, experiences from out of the putrefaction of material existence; they are decidedly not transcendent experiences in which one glimpses the absolute, nor are they religious experiences of any sort.

This fallibility of metaphysical experience forms one side of the dialectic that Adorno deems to be the correct or most worthwhile image of philosophical reflection, while the other side must be an objective moment "antithetical to it and incapable of being assimilated to it." This expression is important: Adorno maintains the subject-object (thesis-antithesis) model of the dialectic developed by Hegel, but asserts that the objective side cannot become identified with or identical to the subjective side. The dialectic thus maintains a tension that cannot, must not, be resolved. No moment of positive identification occurs in which one side is taken into the other or positively synthesized, initiating an on-going process of increasing synthesis. Rather, Adorno assumes a staunchly anti-Hegelian stance (though he recognizes that he owes much to Hegel and Hegelian metaphysics) by insisting that metaphysical experience "now only survives negatively." ${ }^{, 51} \mathrm{He}$ expresses this contradistinction with the following:

\footnotetext{
${ }^{48}$ Ibid., 141.

${ }^{49}$ Ibid., 142.

${ }^{50} \mathrm{Ibid}$.

${ }^{51}$ Ibid., 143.
} 
It lies in the fact that Hegel's philosophy contains a moment by which that philosophy, despite having made the principle of determinate negation its vital nerve, passes over into affirmation and therefore into ideology: the belief that negation, by being pushed far enough and by reflecting itself, is one with positivity. That, Ladies and Gentlemen, the doctrine of the positive negation, is precisely and strictly the point at which I refuse to follow Hegel. ${ }^{52}$

Instead of allowing a positive negation, Adorno prefers to hold on to a negative negation, which he refuses to see as a positive identification. Because one starts with the principle that all metaphysical experience may be fallible, the first moment of the dialectic already includes a sort of negativity insofar as it includes that which normally would (and would have to) remain outside of the system. Hegel would assume that fallibility makes the piece of experience "unworthy of being known",53 and thus would exclude it from the dialectical system. Adorno, on the other hand, realizes (as stated above) that these fallible moments are perhaps the most important things one can attempt to know. Therefore, he begins with the negative, with that which is always excluded, and moves in the second moment of the dialectic to negate the negation. The third moment of the dialectic, however, resists resolution into a positive synthesis. Adorno firmly maintains that one cannot elicit a positive moment out of a negating of the negation of metaphysical experience. To do so would be a return to "the sphere of false, deceptive and, I would say, mythical certainty, in which nothing can be wrong and in which, probably for that reason, everything one said would be all the more hopelessly lost."54 And thus the negative dialectic is born.

In Negative Dialectics Adorno explicates exactly this alternative philosophy that maintains the nonidentity inherent in dialectics. The nonidentity occurs between the two poles of the dialectic, between the first moment as fallible metaphysical experience and the second

\footnotetext{
${ }^{52}$ Ibid., 144.

${ }^{53}$ Ibid., 141.

${ }^{54}$ Ibid., 144.
} 
moment as an objective moment; but nonidentity does not actually mean an identity of difference. It remains nonidentity because the first moment remains always outside the system and because the negative dialectic does not resolve itself into a positive synthesis. Adorno describes nonidentity as "the secret telos of identification. It is the part that can be salvaged; the mistake in traditional thinking is that identity is taken for the goal." ${ }^{, 55}$ Rather than using dialectics to elevate the concept above the nonconceptual (or temporal experience) or attempting to use concepts to "cope with all that is heterogeneous to those concepts," nonidentity between these two poles of the dialectic and turns the concept upon itself, calling for a reflection on the concept's meaning in light of the metaphysical (temporal) experience. The negative dialectic thus encourages philosophy to become self-critical: "Having broken its pledge to be as one with reality or at the point of realization, philosophy is obliged ruthlessly to criticize itself." ${ }^{57}$ The conclusion toward which this negative dialectics inevitably leads becomes starkly clear in the last chapter of the work in which Adorno returns to metaphysical reflection in light of Auschwitz. The negative dialectic finally becomes the oscillation between making metaphysical statements and the negation or critique of such statements (and even of the possibility of making such statements).

The negative dialectic as a means of philosophical reflection manages to walk the line between being either a closed system or an open system, though Adorno does not pretend that it is not a system of some type. One of the major problems of metaphysical systems that Adorno addresses is the fact they are (nearly always) closed systems. These philosophical systems claim to be all encompassing and to, as mentioned above, endow every aspect or concept within the system with a positive interpretation or positive meaning. For Adorno, any search for an all-

\footnotetext{
${ }_{55}^{55}$ Adorno, Negative Dialectics, 149.

${ }^{56}$ Ibid., 4.

${ }^{57}$ Ibid., 3.
} 
encompassing system in which everything has its place can only end in failure. His criticism of closed systems is concise and poignant: "No matter how dynamically a system may be conceived, if it is in fact to be a closed system, to tolerate nothing outside its domain, it will become a positive infinity — in other words, finite and static...Bluntly put, closed systems are bound to be finished." 58 In such systems, everything is filed away into its proper place, and nothing remains outside of the system. If these closed systems were, then, to take up temporality and experience into the task of metaphysics, these too would find their appropriate place and be assigned their necessary meaning or sense. "The system, the form of presenting a totality to which nothing remains extraneous, absolutizes the thought against each of its contents and evaporates the content in thoughts." ${ }^{59}$ The result of the closed system in the face of Auschwitz, in the face of the victims, is precisely that which Adorno finds most inhuman, most reprehensible, the evaporation of the content of experience into positive thought. After Auschwitz, Adorno tells us, one must "balk at squeezing any kind of sense, however bleached, out of the victims' fate.",60

Yet his criticism of closed systems is not against systems per se, and it does not result in giving precedence to open systems. Adorno still operates through a dialectic, albeit a negative one, which remains a sort of system. To be sure, his negative dialectic is not a closed system, since it aims at including that which would normally be outside the system or heterogeneous to the system; at the same time, it's goal is not to render the walls asunder so that the system ravenously sucks everything into itself, as is the risk in open systems. While he critiques closed systems for their inability or unwillingness to include fallible experience, he argues against open systems for their inability to coordinate individual moments beyond themselves. He still sees the task of philosophy and of metaphysics in particular as attempting to supply some structure,

\footnotetext{
58 Ibid., 27.

${ }^{59}$ Ibid., 24.

${ }^{60}$ Ibid., 361.
} 
however tentative or fallible, to thought and experience. He thus writes: "To comprehend a thing itself, not just to fit and register it in its system of reference, is nothing but to perceive the individual moment in its immanent connection with others." Instead of either an open or a closed system, Adorno adopts the model of the constellation, a term he borrows from his friend and intellectual companion Walter Benjamin. ${ }^{61}$ The constellation, as it sounds, coordinates thoughts in a certain relationship to each other, and this relation is then borne in the objects composing the constellation: "Becoming aware of the constellation in which a thing stands is tantamount to deciphering the constellation which, having come to be, it bears within it." ${ }^{\text {.62 }}$ Constellations are not static; they do not reach toward an infinity by which they concretize themselves into immovable concepts. Nor are they so wildly dynamic as to lack any coordination. Rather, constellations change as their content changes, and when they do so the relationships among the objects comprising the constellation also change. This type of system allows the inclusion of fallible experience and resists stasis while also providing a structure to thought and experience, albeit not a final or static one.

As I have alluded in this chapter, Adorno's negative dialectic results in a form of metaphysics that remains tenable in light of the unfathomable suffering of Auschwitz because it becomes the oscillation between metaphysical statements and their critique. He cites both a critical and a rescuing function to metaphysics:

That is to say that metaphysics is always present where enlightened rationalism both criticizes traditional notions and ideas, ideas existing in themselves, as mythological, and at the same time - and not just out of an apologetic need, but out of a concern for truthwants to save or restore these concepts, which reason has demolished, precisely through

\footnotetext{
${ }^{61}$ Benjamin notably invokes the notion of the constellation in Origin of German Tragic Drama, 34, when he writes: "Ideas are to objects as constellations are to the stars." Walter Benjamin, Origin of German Tragic Drama, trans. John Osborne (New York: Verso Books, 1998), 34.

${ }^{62}$ Ibid., 163.
} 
the application of reason, or even to produce them anew from within its own rational resources. $^{63}$

Metaphysics as the negative dialectic must criticize the traditional concepts of the positive synthesis, the preference for concepts over experience, and even the notion of the undisturbed absolute. Nothing escapes the reach of metaphysics' criticism today, not even the negative dialectic itself, for "[i]t lies in the definition of negative dialectics that it will not come to rest in itself, as if it were total. This is its form of hope."64 Nevertheless, the negative dialectic remains a form of metaphysics insofar as it forms constellations of thoughts, coordinating thought and experience rather than leaving individual moments to flounder on their own in unstructured, unbounded nothingness. Moreover, Adorno's negative dialectic as metaphysical reflection remains plausible in the face of Auschwitz because it refuses to exclude the deleterious experience of lived reality, but rather it begins from this experience and calls for thought to reflect upon itself (reprising the notion of critical self-reflection encountered in chapter one), since if metaphysical thinking can be true after Auschwitz then "it must also be a thinking against itself." 65 Beginning from this experience of material existence, it delves itself into the refuse, the rubbish heap of history, refusing to eschew such putrefaction, and instead realizing it as the fallible metaphysical experience that provides the basis for philosophical reflection in the mode of the negative dialectic. After Auschwitz, any divorce of temporality from the realm of concepts, any sundering of the subjective and the objective proves indefensible. From the first moment of his negative dialectic as subjective experience, Adorno rebuffs any attempt at parting ways with the detritus of existence. At the same time, he warns his reader that "After Auschwitz, our feelings resist any claim of the positivity of existence as sanctimonious, as wronging the

\footnotetext{
${ }^{63}$ Metaphysics, 51.

${ }^{64}$ Adorno, Negative Dialectics, 406.

${ }^{65}$ Ibid., 365.
} 
victims; they balk at squeezing any kind of sense, however bleached, out of the victims' fate."66 All the while maintaining the nonidentity inherent in the dialectic between subjective experience and objective reflection, the negative dialectic resists subsuming the refuse of the human past into a final, positive moment. Here we encounter again the injunction against overcoming/mastering the past. The deleterious past will not be overcome by assuming itself into a higher synthesis; instead, one must continue to reflect upon the horrendous suffering not as some spiritual exercise in self-flagellation, but as a means of guarding against the usurpation of experience into a so-called higher realm of positive meaning.

As the oscillation between metaphysical statements and the critique of these statements, between the rescuing function and the critical function, Adorno's metaphysics may be termed a metaphysics in fall. While this phrase does not appear in Adorno's writing in quite this way, he alludes in the last paragraph of Negative Dialectics to a metaphysics in fall. Here he describes the nonidentity inherent in each thought, citing each moment of thinking as the possibility for a thinking against itself; and he closes the book with the following: "There is solidarity between such thinking and metaphysics at the time of its fall. ${ }^{, 67}$ By this he means, and I wish to highlight, that metaphysics can no longer become a final system, but rather metaphysics itself now only survives negatively. It must always persist as a metaphysics in fall, a metaphysics that critically reflects upon itself and thinks against itself in light of the experience of material reality. Placing itself in contrast to those systems that posit strong appeal to an absolute aids in ensuring that this metaphysics remains in fall: "I would say, therefore, that if metaphysical thinking today is to have any chance...it will have to cease being apologetic and pointing to something one can hold onto and never lose, and think against itself. And that means that it must measure itself against

\footnotetext{
${ }^{66}$ Ibid., 361.

${ }^{67}$ Ibid., 408.
} 
the ultimate, the absolutely unthinkable, to have any right to be a thinking at all." ${ }^{68}$ The closed systems that aim at or believe they have attained the absolute are finished; Auschwitz was the final nail in their coffins. Any metaphysical system that seeks to be tenable today must include (without explaining away) the experience of lived reality and must think against itself as a metaphysics in fall.

Adorno's critique of traditional metaphysics and articulation of a form of metaphysics in fall as the only tenable metaphysical reflection after Auschwitz prepares us for the foray into Whiteheadian metaphysics, which I read, similarly, as betraying the same type of oscillations between experience and generality and remarkably similar, though differently constructed, critiques of metaphysical systems that seek dogmatic finality. Additionally, Adorno's notion of the constellation and the rebuff of metaphysical systems that either reach toward transcendence or claim an ossification of concepts marks the way for theological statements that likewise wish to avoid dogmatic finality or appeals to transcendence as a means of escaping the putrefaction inherent in material reality. Indeed, neither metaphysics nor theology must betrayed damaged life, as Adorno's own invocation of an inverse theology will demonstrate in chapters to follow

\footnotetext{
${ }^{68}$ Adorno, Metaphysics, 115.
} 


\section{Chapter 4: Whitehead's Speculative Philosophy as Metaphysics in Fall}

This chapter marks a transition from Adorno and Voeglin, from German philosophy after the Holocaust, back in time, so to speak, to the philosophy of Alfred North Whitehead. I introduce Whitehead here with no illusions that his philosophy will save the day or save metaphysics from the charges leveled by Adorno. In fact, Adorno's warnings must stand; and despite the fact that Whitehead's career was mostly finished before he learned of the programmatic murder of ten million people at the hands of the Nazis, if we are to make use of Whitehead today, we must continue to apply Adorno's strong critiques backwards in time and onto the speculative philosophy developed by Whitehead. To quote at length from Adorno's

Metaphysics, the following serves as a reminder of the warning with which we must proceed.

In face of the experiences we have had, not only through Auschwitz but through the introduction of torture as a permanent institution and through the atomic bomb-all these things form a kind of coherence, a hellish unity-in face of these experiences the assertion that what is has meaning, and the affirmative character which has been attributed to metaphysics almost without exception, become a mockery; and in the face of the victims it becomes downright immoral. ${ }^{1}$

This chapter thus bears the twofold goal of reading Whitehead's metaphysical scheme in tandem with Adorno's critiques and demonstrating Whitehead's scheme as tenable and even helpful in post-Holocaust metaphysical reflection. From this point forward, I use Whitehead's speculative philosophy as the preferred version of metaphysics because of its unique coordination of time and its ability to treat paradigmatic events as bearing universal significance. Chapters five and six will develop my use of Whitehead's metaphysics further by dealing specifically with his

\footnotetext{
${ }^{1}$ Adorno, Metaphysics, 104.
} 
notion of time and his view of God, before I move to unfolding my own post-Holocaust theological position in light of the problem of coming to terms with the past.

Additionally, it is important to note that though we have, in the previous chapter and in this chapter, moved well into the metaphysical realm, we have not left behind the concrete events in Germany in which the problem of Vergangenheitsbewältigung first arose. To the contrary, as I hope to demonstrate, the philosophies highlighted here never seek to move beyond, overcome, transcend, or work through concrete events and experiences, but rather they make these events and experiences the starting point for serious philosophical reflection without ever endeavoring to subsume such moments into a higher realm. In the next chapter we will return specifically to the problem of coming to terms with the past, and to Adorno's and Voegelin's criticisms of this notion, as we examine the relationships among the past, present, and future in Whitehead's philosophy.

\section{Whitehead as Mathematician and Philosopher}

Born in 1861 in Kent, England, Alfred North Whitehead grew up as the son of an Anglican minister. He received his education from one of the best public academies in England, the Sherborne School, and enjoyed a fairly sheltered young life. In 1884 he earned his BA from Trinity College, Cambridge, where he was subsequently elected a fellow. He taught mathematics at Trinity College until 1910, where he supervised the doctoral dissertation of Bertrand Russell and collaborated with Russell on the first edition of Principia Mathematica, a lengthy endeavor to explain mathematics via symbolic logic. Whitehead's relationship with his younger pupil-turned-colleague later became somewhat estranged, as the two moved in divergent philosophical directions. In a letter to Russell, Whitehead once wrote: "You think the world is what it looks like in fine weather at noonday. I think it is what it seems like in the early morning 
when one first awakes from deep sleep."2 After leaving Trinity College in 1910, due to various disagreements with the college electors, Whitehead assumed posts at the University College of London and Imperial College London, teaching largely on physics and philosophy of science. It was here in 1920 that Whitehead published Concept of Nature, marking his early move toward viewing the world as comprised of series of events, rather than enduring matter. In 1924 he received an invitation to teach philosophy at Harvard University; he accepted, and he and his wife Evelyn spent the remainder of their lives in the United States, taking up residence in another Cambridge. At Harvard, Whitehead's turn to metaphysics marked a new phase in his philosophical career, as may be seen in such works as Science and the Modern World, Religion in the Making, and Process and Reality. In 1925 and 1926 Whitehead presented the Lowell Lectures, a series of four lectures in King's Chapel in Boston. The manuscript of the 1925 lectures was subsequently published as Science and the Modern World, and the 1926 lectures as Religion in the Making. These lectures demonstrate the development of Whitehead's metaphysics, introducing such concepts as the actual entity, eternal objects, and the fallacy of misplaced concreteness. In 1927 Whitehead was invited as lecturer for the famous Gifford Lectures in natural theology at the University of Edinburgh in Scotland. Two years later he published the text of these lectures as his opus magnum, Process and Reality, a full-length work in speculative philosophy that fully articulates his metaphysical scheme. After Process and Reality, Whitehead wrote two other notable books that mark a move beyond (but perhaps not away from) metaphysics: Adventures of Ideas, published in 1933, and Modes of Thought, in 1938.

Whitehead's scholarly work ranges from such subjects as mathematics and physics, the philosophy of science, and metaphysics to theories of education and discussion of women's

\footnotetext{
${ }^{2}$ Quoted in Philip Rose, On Whitehead, Preface (Belmont, CA: Wadsworth/Thomas Learning, Inc., 2002).
} 
education and emancipation and finally to the concepts of civilization, history, and religion. The notions that the world is continually in process and that there is a connectedness among things underlies all of his work in these various fields. In Adventures of Ideas he describes the principle of process with the following: "the very essence of real actuality—that is, of the completely real-is process. Thus each actual thing is only to be understood in terms of its becoming and perishing."” As things become and perish they exhibit connectedness by the ways in which they perceive and take into account both previous moments in the world process and the fact that there will be future moments after their perishing. These two principles, which form major components of his metaphysical scheme, find exemplification in all of his works, whether in tracing the history of scientific development, religion, or the unfolding of civilization.

Nevertheless, Whitehead does not claim a progression in linear time from one epoch or space of time to the next: "The progress of civilization is not wholly a uniform drift toward better things." There is no sense in which the world continues toward some higher perfection or ultimate telos - and this is a point to which we will return in the final chapter. Quite to the contrary, he writes that the only telos in the universe may be said to be the drive toward creativity and novelty, two other vital notions in his metaphysics, which will be discussed below.

Whitehead's influence has been felt in an even wider variety of fields than those in which Whitehead himself wrote and lectured, including literary theory, post-structuralist philosophy, environmental ethics, economic theory, and (most notably for this project) theology. Charles Hartshorne, a student of Whitehead's at Harvard, simultaneously with Henry Nelson Wieman and Bernard Loomer, developed Whitehead's notion of God and the significance of God in his speculative philosophy into what was soon to become process theology. Hartshorne, Loomer

\footnotetext{
${ }^{3}$ Alfred North Whitehead, Adventures of Ideas (New York: The Free Press, 1933), 274.

${ }^{4}$ Alfred North Whitehead, Science and the Modern World (New York: The Free Press, 1925), 1.
} 
(whose work we will examine specifically in chapter six), and Wieman, were each on the faculty of the University of Chicago and the University of Chicago Divinity School; each were heavily influenced by Whitehead's work and developed certain trajectories of process thought and of the burgeoning process theology. Later, John B. Cobb, Jr., a student of Hartshorne at Chicago, brought his own process thinking to Claremont, in turn initiating a variety of divergences or trajectories, by means of his many students and his own diverse interests, in which process philosophy/theology has spread. Whitehead's own metaphysical system resists the tendency toward any doctrinal reading of his scheme, since his own metaphysics continued to develop throughout and up to the end of his career. Consequently, a number of divergent readings of Whitehead, particularly regarding Whitehead's God, can be found today. My use of Whitehead in this dissertation will follow both Bernard Loomer's work regarding God's stature or size as well as Roland Faber's de/constructive and post-structuralist reading of Whitehead, particularly with regard to notions of novelty and God's futurity. I examine and develop these readings of Whitehead because I find them most useful for building a critique of coming to terms with the past and for unfolding a theology of remembrance. Moreover, I (implicitly and explicitly) critique other readings of Whitehead in subsequent pages, particularly those that seem to me most unable to heed Adorno's warnings and prohibitions regarding metaphysical reflection after Auschwitz. As I have attempted to demonstrate in this short paragraph, Whiteheadians are not of one accord; however, this is not viewed as a deficiency in the philosophical community, but actually as an embodiment of Whitehead's repeated claims that dogmatization leads to violence and ultimately to decay. 


\section{Speculative Philosophy as a System of General Ideas}

Whitehead names his goal at the beginning of Process and Reality as the "endeavour to frame a coherent, logical, necessary system of general ideas in terms of which every element of our experience can be interpreted. ${ }^{55}$ This for him is the goal of speculative philosophy, a term he uses synonymously with metaphysics. From this statement it is evident that experience plays a vital role in his metaphysical system. Whitehead takes up the task of explaining actuality and coordinating the explanation of actuality within a broad horizon—-the system of general ideas that he endeavors to frame. Therefore, he does indeed aim at establishing a system in which, by explaining actuality, every drop of experience can be interpreted, and as an oft-quoted passage from Adventures of Ideas tells us, this includes “experience drunk and experience sober, experience sleeping and experience waking...experience self-conscious and experience selfforgetful, experience intellectual and experience physical, experience religious and experience skeptical..." For Whitehead, "[n]othing can be excluded," but rather "to discover some of the major categories under which we can classify the infinitely various components of experience, we must appeal to evidence relating to every variety of occasion." ${ }^{77}$ Yet this appeal to experience and actuality does not place Whitehead firmly on the side of the empiricists (though my own tendency will be to place him as more of an empiricist than a rationalist, as I will explain below). As he straightforwardly notes, this metaphysical system has both an empirical and a rational side. In striving toward a system of general ideas in terms of which all experience can be interpreted, Whitehead employs both the imagination and reason, and thus he may also be said to include a

\footnotetext{
${ }^{5}$ Alfred North Whitehead, Process and Reality: Corrected Edition, ed. David Ray Griffin and Donald W. Sherburne (New York: The Free Press, 1978), 3.

${ }^{6}$ Adventures of Ideas, 226.

${ }^{7}$ Ibid.
} 
rationalist side. ${ }^{8}$ While some interpreters of Whitehead have variously placed him on one side or other of this empirical/rational divide, others maintain that he resists final categorization into either camp. ${ }^{9}$ Whitehead could be named an empiricist because he starts from actuality, yet he could also be named a rationalist since he uses reason and deduction (as well as imagination ${ }^{10}$ ) to coordinate experiences into a general scheme. While I affirm, and think that one must not neglect, the tension between his empirical and rational sides, I (like Loomer) emphasize the empirical for two reasons: First, as will become clear in this chapter, holding experience and actuality as primary resists philosophical moves that subsume all experience into an overarching metaphysical narrative in which each experience must exhibit some positive value. Second, emphasizing Whitehead's empirical side allows me to align him more clearly with the historical materialist readings I find most useful in finally developing a theology of remembrance and a means of viewing deleterious aspects of the past.

As we return to Whitehead's explication of his system of general ideas at the outset of Process and Reality we can see the empirical and rational sides of his philosophy coming into view. He includes two rational criteria and two empirical criteria in his definition of speculative philosophy: "The rational side is expressed by the terms 'coherent' and 'logical.' The empirical side is expressed by the terms 'applicable' and 'adequate.",11 On the rational side, by coherent he means that the ideas by which the system is developed presuppose each other "so that in isolation they are meaningless." 12 Thus, from the outset Whitehead includes a form of the

\footnotetext{
${ }^{8}$ Thomas E. Hoskinski, Stubborn Fact and Creative Advance: an Introduction to the Metaphysics of Alfred North Whitehead (New York: Rowman \& Littlefield Publishers, Inc., 1993), 12.

${ }^{9}$ Lewis Ford describes the empirical/rational debate in process thought particularly is it relates to process theology. He places Charles Hartshorne, Schubert Ogden, John B. Cobb, Jr., and David Griffin on the side of the rationalists and Bernard Loomer, Bernard Meland, Nancy Frankenberry, and William Dean on the side of the empiricists. See Lewis Ford, Transforming Process Theism (Albany, NY: State University of New York Press, 2000), 310.

${ }^{10}$ Whitehead, Process and Reality, 5.

${ }^{11}$ Ibid., 3 ,

${ }^{12}$ Ibid.
} 
principle of connectedness used to guard against the tendency toward abstraction in metaphysics. No one idea within the system can be abstracted from the others: "In other words, it is presupposed that no entity can be conceived in complete abstraction from the system of the universe, and that it is the business of speculative philosophy to exhibit this truth." ${ }^{, 13}$ By logical Whitehead simply means that the system lacks internal contradiction. On the empirical side, the criteria of applicable means that the system must "have an application in some facts of experience, ${ }^{, 14}$ while adequate requires that there be no experiences that are not interpretable by the system. Finally, the two sides, rational and empirical, are bound together, Whitehead tells us, by the criteria of necessity: adequacy in this scheme does not mean adequate only to those experiences that happen to be considered, but rather it means adequate to all experience. Thus, by necessary he intends that the system contain within itself a sense of universality for all experience.

Before moving on to explain some of the basic terms Whitehead employs in his metaphysics, let us briefly compare Whitehead's use of experience with Adorno's. While both place experience at the forefront of metaphysical reflection, the two seem to differ radically with regard to precisely what experience each is willing to include. Whitehead asserts that all experience, both cognitive and non-cognitive, must be included. No experience can be excluded if the system of general ideas has any hope of being adequate. Adorno, on the other hand, wants to include only some types of cognitive experience that he deems to be metaphysical experience. Not all experience can be metaphysical experience, and Adorno is clear to exclude religious experience from the category of metaphysical experience on the grounds that "[f]ar less emphasis is put on a primary, immediate vision than one imagines; far more attention is paid to

\footnotetext{
${ }^{13}$ Ibid.

${ }^{14}$ Hoskinski, 14.
} 
the [topoi] of so-called religious experience than to pure subjectivity than might be supposed."15 What he seems to include among metaphysical experiences are subjective experiences of concrete events at a cognitive level. I realize this is equally as vague as Adorno's own description of metaphysical experience, but perhaps the category can become more clear by naming that which he wishes to exclude: religious experience and experience derived from learning or tradition cannot be included, non-cognitive experience cannot be included; objective experience (those things deducible by reason or accepted as rational knowledge) cannot be included. This leaves us with a wide range of subjective experience, but a notably smaller range of experience than Whitehead is willing to include. As stated above, Whitehead seeks to include any and all experience in his system of general ideas, and he mentions the inclusion of religious experience specifically: "religion is among the data of experience which philosophy must weave into its own scheme. Religion is an ultimate craving to infuse into the insistent particularity of emotion that non-temporal generality which primarily belongs to conceptual thought alone."16 This distinction in terms of what experience to include must be remembered as we move forward in our evaluation of Whitehead's metaphysics as tenable after Auschwitz.

In unfolding his speculative philosophy, Whitehead found it necessary to create a new vocabulary so as to make clear in the reader's mind the distinction between his own usage of words and phrases and traditional philosophical, psychological, or scientific usage. As Voegelin argued that traditional philosophical vocabulary had become entangled with ideologies, Whitehead believes that traditional metaphysical vocabulary has assumed a "false air of adequate precision." In other words, he holds that the language of metaphysics has so passed into common vernacular that its spurious clarity leads toward doctrinal thinking. If one assumes to

\footnotetext{
${ }^{15}$ Adorno, Metaphysics, 138.

${ }^{16}$ Whitehead, Process and Reality, 15-16.
} 
know the precise meaning of a philosophical term, then one also assumes to hold the concept articulated by the term firmly within one's grasp. Not so, argues Whitehead. "The Whiteheadian vocabulary," suggests Elizabeth Kraus, "is not at all like the precisely defined terms of the Rationalists. It retains the evocative character and deliberate ambiguity of poetic usage." ${ }^{17}$ The vocabulary itself is in process and can only be defined in terms of the rest of the vocabulary - no term can be abstracted from the system and still make sense. Similarly, understanding Whitehead's metaphysical terms goes hand in hand with understanding his metaphysical system. The terms cannot be defined outside of the system or without explaining their meaning within the system and in relation to all the other parts of the system.

The first set of vital notions in Whitehead's speculative philosophy concerns the actual occasion or actual entity. ${ }^{18}$ Every drop of experience or every moment of experience is an actual entity or is comprised of multiple actual entities, and these moments are "complex and interdependent" 19 - complex because they cannot be abstracted from the antecedent or subsequent moments and interdependent because they do not exist in isolation, but only in relation to other actual entities. ${ }^{20}$ Actual entities are "the final real things of which the world is made up. There is no going behind actual entities to find anything more real. ${ }^{21}$ Here at this most basic level of reality, Whitehead replaces the notion of substance with that of the actual entity. Actual entities are the primary building blocks of reality, the basic components comprising all of material existence. Actual entities then are analyzable into what Whitehead terms 'prehensions.' The prehension is the way in which the actual entity "feels" the world

\footnotetext{
${ }^{17}$ Elizabeth M. Kraus, The Metaphysics of Experience: A Companion to Whitehead's Process and Reality (New York: Fordham University Press, 1998), 4.

${ }^{18}$ The terms 'actual entity' and 'actual occasion' may be used synonymously, except when in discussion of God, as God is the only actual entity that is not also an actual occasion. See chapter 6. See also Isabelle Stengers,

"Whitehead's Account of the Sixth Day," in Configurations 13 (2005): 44.

${ }^{19}$ Whitehead, Process and Reality, 18.

${ }^{20}$ Hoskinski, 21.

${ }^{21}$ Ibid.
} 
around it; yet, Whitehead uses the term prehension instead of apprehension to denote that prehension occurs at a pre-cognitive level. A prehension is the "gathering of aspects located 'there' into the immediacy of a 'here.",22 Through the prehension the actual entity gathers together past moments and the expectation of future moments as it "grows together," becomes, or concresces. Whitehead himself notes that a prehension "reproduces in itself the general characteristics of an [antecedent] actual entity: it is referent to an external world, and in this sense will be said to have a 'vector character'; it involves emotion, and purpose, and valuation, and causation. ${ }^{, 23}$ An actual entity may positively or negatively prehend past actual entities depending upon whether or not it evaluates them as relevant for the becoming of the present actual entity. Additionally, Whitehead divides prehensions into two types: physical and conceptual. Physical prehensions are the type of prehensions I have been describingprehensions of past actual entities-whereas conceptual prehensions are prehensions of what Whitehead calls eternal objects. Eternal objects are also referred to as "Pure Potentials for the Specific Determination of Fact, or Forms of Definiteness, ${ }^{, 24}$ which means what it sounds like it means: eternal objects provide potential forms for the becoming of an actual entity. Sometimes likened to Plato's forms, eternal objects are pure potentialities, they "can be described only in terms of [their] potentiality for 'ingression' into the becoming of actual entities..." ${ }^{25}$ The process of prehension, the combination of past data into a new "fact" or new actual entity, and the ingression of eternal objects is called concrescence (literally "growing together"), and once an actual entity has concresced or "become" it is said to have reached satisfaction. At the point

\footnotetext{
${ }^{22}$ Kraus, 18.

${ }^{23}$ Whitehead, Process and Reality, 19.

${ }^{24}$ Ibid., 22.

${ }^{25}$ Ibid., 23.
} 
of satisfaction the actual entity perishes, which means that it in turn becomes a moment of the past, a part of the wealth of past data that will be prehended by subsequent actual entities.

In explaining his metaphysical scheme Whitehead also introduces four principles that will be pertinent to the discussion as I move forward. First, the principle of creativity is the "ultimate principle by which the many, which are the universe disjunctively, become the one actual occasion, which is the universe conjunctively." 26 Creativity is the means by which the many (the multiplicity of past moments) become the one as the unity of a single actual entity. Thus, creativity is inherent in each concrescence, and it introduces novelty into each becoming actual entity insofar as each subsequent actual entity concresces differently than previous actual entities, even if only by virtue of the fact that the data of the past from which it can draw has been increased with each passing moment, with each perishing of antecedent actual entities. Whitehead terms this process of producing novel entities via the principle of creativity as the creative advance: it is "the advance from disjunction to conjunction, creating a novel entity other than the entities given in disjunction." ${ }^{27}$ Creativity advances the world from the many-ness of the past to the oneness of the present moment back again to many-ness as the present actual entity reaches satisfaction and perishes. Thus, the "many become one, and are increased by one.",28

Second, the principle of relativity may be stated as the idea that "it belongs to the nature of 'being' that it is a potential for every 'becoming.",29 Quite simply, every past or perished actual entity becomes a datum of the past to be prehended in all present and future moments, or rather, each past entity (as a "being") "is a factor that must somehow be taken into account by

\footnotetext{
${ }^{26}$ Ibid., 21.

${ }^{27}$ Ibid.

${ }^{28}$ Ibid.

${ }^{29}$ Ibid., 22.
} 
every present actual entity in the process of becoming. ${ }^{30}$ The principle of relativity will be significant for our discussion in chapter six on Whitehead's notion of the relation among the past, present, and future. Third, Whitehead states the principle of process as follows: "That how an actual entity becomes constitutes what that actual entity is...Its 'being' is constituted by its 'becoming.' This is the 'principle of process." ${ }^{31}$ How an entity concresces, the way in which it prehends or feels its past, determines what that entity will be. Whitehead's statement that an actual entity's being is constituted by its becoming implies that preference or importance is given to becoming over and above being, since the becoming is what determines the being. Moreover, once an actual entity can be said to have "become," it is dead; it perishes and becomes an object of the past. Thus, the interesting part of the actual entity, the portion in which creativity produces novelty, lies in its concrescence, in its becoming. Finally, Whitehead reinterprets the ontological principle to say that "actual entities are the only reasons; so that to search for a reason is to search for one or more actual entities. ${ }^{, 32}$ As he has previously stated, there is no going behind actual entities; they are the final and most basic real things, and thus there are no reasons in the universe outside of actual entities. The ontological principle significantly reinforces a strong empirical position and safeguards against appeal to some concept beyond experience as an effort to explain actual experience. As Hoskinski reminds us, "no reason (in a metaphysical explanation) is acceptable unless it can be referred somehow to something actual. ${ }^{, 33}$ Whitehead's re-appropriation of the ontological principle thus exhibits resonance with Adorno's view that universal concepts may no longer be employed to explain the experiences of

\footnotetext{
${ }^{30}$ Hoskinski, 25.

${ }^{31}$ Whitehead, Process and Reality, 23.

32 Ibid., 24.

${ }^{33}$ Hosinski, 20.
} 
lived reality. In both cases one can only explain experience by starting from experience as actuality, not by appealing to concepts or categories outside of and divorced from experience.

Before moving on to a discussion of Whitehead's philosophical method and an elucidation of the reasons for which I name his speculative philosophy as a metaphysics in fall, there remains one further significant aspect of his metaphysics to unfold, and this concerns the status of subjects and objects. In Whitehead, the subject/object dichotomy of traditional philosophy receives a fresh twist. While Whitehead does not erase the distinction between subjects and objects, the two do become relative terms. ${ }^{34}$ Subjects and objects are no longer fixed categories in his speculative philosophy, but rather an entity comes into the world as a subject and leaves as an object. The term subject, or "subject-superject" as Whitehead prefers, refers to present actual entities in the mode of concrescence; whereas the term object names actual entities after they have reached satisfaction and perished. "The word 'object' thus means an entity which is a potentiality for being a component in feeling; and the word 'subject' means the entity constituted by the process of feeling, and including this process. ${ }^{, 35}$ Subjects, according to Whitehead, have a "superjective" nature in that they emerge from the world out of the disjunctive data of the past and transcends actuality by passing into objectivity as an impetus for future occasions by way of their "superjective" nature. Again turning to his empirical side, he argues in favor of always using the phrase "subject-superject" as opposed to simply "subject" because he wishes to distinguish what he means by subjects from what Kant and the idealists mean by subjects. He writes: "For Kant, the world emerges from the subject; for the philosophy of organism [another term he uses for his process metaphysics], the subject emerges from the

\footnotetext{
${ }^{34}$ Whitehead, Adventures of Ideas, 176.

${ }^{35}$ Whitehead, Process and Reality, 88.
} 
world — a 'superject' rather than a 'subject." ${ }^{36}$ Thus, while the terms subject and object are relative in time to the life of the actual entity, the world is not relative to any given subject. Moreover, the superjective nature denotes the moment at which the subject as actual entity has reached its full synthesis as a unity of the many from which it arose and hurtles itself forward into objectivity as past datum for subsequent subject-superjects. ${ }^{37}$ Rather than adopting an idealist version of subjectivity, Whitehead labels this interpretation of subjects and objects and the relation between the two as "the fundamental structure of experience.",38

\section{Whitehead's Philosophical Method}

With the basic notions of Whitehead's metaphysical scheme in place, we can now examine his philosophical method, the process of descriptive generalization. Explanations of his method appear most prominently in the early pages of Process and Reality and in the later portion of Adventures of Ideas, and in both places Whitehead consistently argues that philosophy must begin with particular experiences before moving to larger generalities, and not vice versa. This method of descriptive generalization thus corresponds to the metaphysical theory or working hypothesis that Whitehead develops. In Adventures of Ideas he maintains that theory must dictate method, since "you cannot prove a theory with evidence which that theory dismisses as irrelevant. ${ }^{\prime 39}$ For instance, if we seek with Whitehead to develop a system of general ideas in which every moment of experience is interpretable, then the working hypothesis of this theory dictates the method by which we proceed. As we shall see, Whitehead's method corresponds to his working hypothesis in that it allows one to test assumptions derived from one set of experiences among other experiences, thereby ensuring the applicability of theory, which is one

\footnotetext{
${ }^{36} \mathrm{Ibid}$.

${ }^{37}$ Kraus, 55 .

${ }^{38}$ Whitehead, Adventures of Ideas, 176.

${ }^{39}$ Ibid., 221.
} 
of the measures by which Whitehead sets out to gauge his system in the opening paragraphs of Process and Reality.

While his method begins with actuality (actual entities) and also involves moments of abstraction, it is neither entirely inductive nor entirely deductive. Rejecting a rigid empiricism, Whitehead criticizes the Baconian method of induction for its inability to move science beyond where it began, since it failed to test its hypothesis deduced from concrete fact in areas outside its own "restricted locus." 40 What lacks in a purely deductive method, Whitehead remarks, is the "play of free imagination"; and indeed Whitehead's philosophical method requires an imaginative leap, which he describes as analogous to the flight of an airplane. "It starts from the ground of particular observation; it makes a flight in the thin air of imaginative generalization; and it again lands for renewed observation rendered acute by rational interpretation. $" 41$ Beginning with a particular experience, the method of descriptive generalization then forms a working hypothesis, which it tests for applicability to other experiences. Whitehead has written that the method of philosophy is that of the working hypothesis, and the formation of this hypothesis constitutes a certain abstraction from individual experience to a larger generality, "but in the move the individuality of the starting point is not analyzed away." ${ }^{42}$ Rather, the subjective fact of the starting point maintains its individual integrity because it is not subsumed into abstraction. The only point of abstracting to larger generalities is to test those generalities in other concrete moments and not to remain at the level of abstraction, viewing it as a somehow higher level. Thus, as Kraus writes, "The true activity of understanding consists in a voyage to abstraction which is in fact a voyage to the more fully concrete."43

\footnotetext{
${ }^{40}$ Whitehead, Process and Reality, 5.

${ }^{41}$ Ibid.

${ }^{42}$ Kraus, 41.

${ }^{43}$ Kraus, 42.
} 
What Whitehead's method further refutes, aside from a rigid Baconian induction, is a solely deductive method. One cannot begin with a set of first principles that are clear and irrefutably certain in order to then deduce from these principles down to the level of experience. Implied in this assertion of Whitehead's is the belief that these first principles are not knowable a priori; rather, they require induction from one or more empirically observable moments of experience; even more significantly, they are determined by and derived from these moments of experience and must necessarily change or revise themselves in order to maintain their applicability to new experience. Whitehead terms the dogmatic fallacy "the belief that the principles of its working hypotheses are clear, obvious, and irreformable." ${ }^{, 4}$ When one assumes a set of principles as final, rigid and then tries to deduce from these the evidence to prove a working hypothesis, one has committed the dogmatic fallacy and has begun from abstraction rather than concrete events. As a result, "the accurate expression of the final generalities is the goal of discussion and not its origin." 45 Whitehead's method allows one to move from experience to a set of larger generalities, or as he writes from a particular fact or a species to the genus, but the opposite cannot be true: "There can be no descent from a mere genus to a particular fact, or to a species." 46 Following Whitehead's flight of the airplane, the method of descriptive generalization begins with the concrete fact of experience as actuality, abstracts via a moment of inductive reasoning to the larger generalities or general ideas that comprise the metaphysical system, and then returns again to concrete experience in another field of knowledge by means of deduction in order to test the working hypothesis that is the larger generalities. Only by testing the system of general ideas in as wide a variety of experiences as possible can the system ensure its thorough applicability and hence its function as a system of general ideas in

\footnotetext{
${ }^{44}$ Whitehead, Adventures of Ideas, 223.

${ }^{45}$ Whitehead, Process and Reality, 8.

${ }^{46}$ Whitehead, Adventures of Ideas, 235.
} 
terms of which every experience can be interpreted. ${ }^{47}$ Imagination and creativity find application in this method as it involves an imaginative leap in order to test the system's applicability to a wider set of experiences, and both this act of testing and its results issue into a creative interchange among previously divergent fields of thought, arousing novel facts and thereby also continually revising the system of larger generalities itself.

While this philosophical method requires moments of abstraction in order to form the larger generalities which make up the metaphysical system, Whitehead cautions against mistaking the abstract for the concrete. In Science and the Modern World he first introduced his fallacy of misplaced concreteness when criticizing seventeenth century science for relying on descriptions of the universe derived from abstractions and then accepting these descriptions as concrete. In Process and Reality he applies the fallacy to actual entities and the method of descriptive generalization. "The aim at generalization is sound," Whitehead writes, "but the estimate of success is exaggerated." ${ }^{48}$ One of the ways in which the success of generalization has traditionally been overstated is by committing the fallacy of misplaced concreteness, which he restates here as "neglecting the degree of abstraction involved when an actual entity is considered merely so far as it exemplifies certain categories of thought." ${ }^{, 49}$ Taking the categories of thought as concrete, rather than the actual entity itself, results in committing the fallacy of misplaced concreteness, in giving preference to abstract categories over experience. I have mentioned above, and Whitehead himself implies, that there is a moment of abstraction in the process of generalization; however, we must be clear to note that the two are not the same. The type of generalization employed by Whitehead involves abstraction because it is a widening of application (generalization) in order to test the theory of general ideas, which is an abstraction in

\footnotetext{
${ }^{47} \mathrm{Cf}$. Whitehead, Adventures of Ideas, 237 and Process and Reality, 3.

${ }^{48}$ Whitehead, Process and Reality, 7.

${ }^{49}$ Ibid., 7-8.
} 
that it focuses on the categories rather than the moments of experience themselves (ie. the analogy of genus versus species or particular fact mentioned above). Whether or not a philosophy can be measured successful, according to Whitehead, depends upon "its comparative avoidance of this fallacy, when thought is restricted within its categories." 50 Thus, there is nothing wrong with moments of abstraction - in fact abstraction is necessary at points in order to coordinate experiences beyond themselves - however, one must never mistake the abstraction for the concrete.

\section{Oscillation Between Experience and Abstraction}

In this final section I wish to draw a number of comparisons between Whitehead's metaphysics and both Adorno's negative dialectic and his critique of metaphysics in order to demonstrate Whitehead's speculative philosophy as itself a metaphysics in fall. I ultimately maintain that, like Adorno's negative dialectic and alongside his warnings against metaphysics as usual, Whitehead's process metaphysics succeeds in being neither a closed nor an open system, but one that begins with experience and maintains a principle of internal revisability in light of the unfolding of novel moments of experience, whether positive or negative.

Additionally, it refuses to explain away that actuality which it takes as its starting point by refusing the move to abstraction as preferred over the particular or concrete moment. Whitehead, like Adorno, wishes to avoid positing a dichotomy between a realm of existence and a realm of ideas that deduces reasons for the former. Despite the similarities that I will draw, however, I by no means attempt to harmonize Adorno and Whitehead (which would indeed prove to be a strange project). I will allow the differences to lie where they are, without attempting to cover them over or explain them away.

${ }^{50}$ Ibid., 8. 
In beginning this comparison of Adorno and Whitehead, it is intriguing to note the two very different backgrounds from which each approaches the task of or critique of metaphysics. Adorno, as we have seen, moves between, or perhaps simultaneously in, the fields of social critical theory and philosophy. He relies on a strong materialist underpinning that is steeped in the Hegelian tradition of the dialectic. Interestingly, on the other hand, one would be hardpressed to find a single reference in all of Whitehead's writing to Hegel, much less to the dialectic as a preferred form of logic. He exhibits a high degree of knowledge in Kant, Bradley, Bergson, William James, the British Empiricists (Locke, Hume and Berkley), and in Greek philosophy (namely Plato); though Hegel remains curiously absent. In fact, Whitehead owns up to not having read Hegel in his Essays in Science and Philosophy (published in 1947):

You will not be surprised when I confess to you that the amount of philosophy I have not read passes all telling, and that as a matter of fact I have never read a page of Hegel. That is not true. I remember when I was staying with Haldane at Cloan I read one page of Hegel. But it is true that I was influenced by Hegel. ${ }^{51}$

His Hegelian influence comes through colleagues at Harvard, through his friendship with Lord Richard Haldane, whom he notes had a "Hegelian point of view," shall see below, through his frequent forays into British Romantic poetry. It is obvious from Whitehead's methodological description, as well as from his background, that he approaches the task of metaphysics from a largely scientific viewpoint. His work in mathematics, physics, and the philosophy of science have perhaps uniquely prepared him to view metaphysics as a largely empirical endeavor, though his strong appeal to the Kantian tradition prevents his philosophy from limiting itself to sense perception or to one locus of experience. However, aside from the philosophers mentioned above and the scientific background from which Whitehead comes to

\footnotetext{
${ }^{51}$ Alfred North Whitehead, Essays in Science and Philosophy (New York: Greenwood Press, 1947), 116. Quoted in Antoon Braeckman, "Whitehead and German Idealism: A Poetic Heritage," in Process Studies 14, no. 4 (Winter, 1985): 265.

${ }^{52}$ Ibid.
} 
metaphysics, he was also greatly influenced by the Romantic poetry of Coleridge, Shelley, and Wordsworth, who in turn were influenced (primarily through Coleridge) by German Idealism. In his article on Whitehead's relationship to German Idealism, Antoon Braeckman describes Coleridge's interest in the philosophy of Kant, Schelling and Schlegel, an interest that came through as a strong influence in his own writing. Wordsworth likewise took up the philosophical concepts and worldview of some of the German Idealists via Coleridge; and Whitehead — who began reading the poetry of Coleridge, Shelley, and especially Wordsworth in grade school — seems to have vicariously picked up this influence of German Idealism through his literary relationship with Wordsworth. Notably, Braeckman writes that the concepts of imagination and creativity seem to correlate more or less with Kant and Schelling's understanding of imagination as a part of the synthesis of the many into the one. For Kant and, more specifically, Schelling, the "imagination can be understood as the activity whereby the infinite is unified into the finite, or as the act through which the many become one." ${ }^{.53}$ In Whitehead the principle of creativity may be seen analogously as that which is inherent in the act of synthesizing disjunctive diversity into the unity of the single actual entity. Moreover, Braeckman attributes Whitehead's understanding of nature as largely subjective, rather than a view of nature as merely mechanical, to the influence of Wordsworth who had previously received this perspective from the philosophy of Schelling.

This influence of German Idealism on Whitehead via British Romantic poetry makes its presence know in some very significant places, since the role of creativity in Whitehead's metaphysics is rather central. While Braeckman does not mention a Hegelian influence directly in his article, others have pointed toward possible connections with Hegel in primarily two areas. Charles Nussbaum has explored the relation between Whitehead's speculative philosophy and

\footnotetext{
${ }^{53}$ Braeckman, "Whitehead and German Idealism: A Poetic Heritage," 278.
} 
Hegel's dialectic in some detail. He notes a possible influence of Hegel on Whitehead (or at least a correspondence between the two) in the relationship between particular (actual entity) and universal (eternal objects) ${ }^{54}$, which I will describe below in relation to the reformed subjectivist principle, and in the fact that for both thinkers every occasion becomes a synthesis between being and not-being (since for Whitehead those actual entities that have perished have passed into non-being). ${ }^{55}$ In his article on types of explanation in Hegel and Whitehead, Klaus Hartmann cites a sort of dialectic at play in Whitehead's model of the actual entity, since the actual entity establishes "itself through prehensions of its Other..."56 Both Hartmann and George L. Kline refer to Gregory Vlastos's early study of Whitehead and Hegel in which Vlastos differentiates between a "homogenous" dialectic in Hegel and a "heterogenous" dialectic in Whitehead, meaning that all of Hegel's categories of existence are reducible to Geist, to "the nature of Idea," whereas Whitehead's categories are "diverse and irreducible." ${ }^{, 57}$ Vlastos thus argues that any dialectical movement in Whitehead must be understood rather differently that in Hegel, since Whitehead's dialectic does not issue into a movement between positive and negative statements that build off of one another. ${ }^{58}$

Regardless of any similarities and the possible (though perhaps largely imagined or unknown) influence of Hegel on Whitehead, we can safely surmise with Charles Nussbaum and Victor Lowe that Whitehead's logic is certainly not a dialectical logic. ${ }^{59}$ As he defines his use of

\footnotetext{
${ }^{54}$ Charles Nussbaum, "Logic and the Metaphysics of Hegel and Whitehead," in Process Studies 15, no. 1 (Spring 1986): 41.

${ }^{55}$ Ibid., 48.

${ }^{56}$ Klaus Hartmann, "Types of Explanation in Hegel and Whitehead," in Hegel and Whitehead: Contemporary Perspectives on Systematic Philosophy, ed. George R. Lucas, Jr. (Albany, NY: State University of New York Press, 1986), 79.

${ }^{57}$ George L. Kline, "Concept and Concrescence: An Essay in Hegelian-Whiteheadian Ontology," in Hegel and Whitehead: Contemporary Perspectives on Systematic Philosophy, ed. George R. Lucas, Jr. (Albany, NY: State University of New York Press, 1986), 141.

${ }^{58}$ Ibid.

${ }^{59}$ Nussbaum, 32.
} 
the term logic in the first few paragraphs of Process and Reality, logic for Whitehead specifically excludes contradiction, and thus he does not proceed by a logical method of thesis, antithesis, and synthesis, which necessarily includes a contradiction between the first and second movements of the dialect. This point sets Whitehead apart from Adorno from the start, since Adorno continues to employ a modified version of the Hegelian dialectic - albeit one that denies a positive synthesis. Nevertheless, the point that I want to make here is that Whitehead's metaphysical system does involve what I would like to call an oscillation between the concrete and the abstract, or between moments of experience and the larger scheme of general ideas; and in this sense Whitehead's metaphysics bears a strong resemblance to Adorno's own system. As I have shown, Whitehead clearly seeks to avoid mistaking the abstract for the concrete. $\mathrm{He}$ invokes the fallacy of misplaced concreteness at several points throughout his writing, repeatedly reminding his reader of this chief error in philosophy. At the same time, he realizes that moments of abstraction are necessary in order to coordinate moments of experience into a system of general ideas. We discussed above Whitehead's flight of the airplane, taking off from one moment of experience, flying through the thin air of abstraction in order to land again among new moments of experience, thereby testing the working hypothesis that is the metaphysical system. I suggest that this analogy denotes the oscillation between experience and system, or between concrete fact and momentary abstraction. His speculative philosophy begins with experience, then abstracts from experience only to return again to experience, never aiming at either finality in an abstract system or a positive synthesis of the moment of experience into the realm of ideas. Elizabeth Kraus also notices the oscillation between fact and abstraction as central to Whitehead's method of philosophic discovery: "there is a dialectical movement in understanding, a movement encompassing the exploration and explication of wider and wider 
contexts, each step of which further enriches the knowledge of the original fact. ${ }^{\circ 0}$ Kraus, going so far as to refer to the movement as dialectical, affirms that this oscillation always returns to the concrete. I suggest — despite the insistence of Kraus, Vlastos, and Hartmann — it is perhaps going too far to refer to Whitehead as dialectical, since a dialectic always involves some integration of the contradiction between the two terms, poles, or ideas. Rather than integrating contradiction, however, Whitehead maintains the contrast, and the only integration is the move to novelty. This is not a synthesis that leads to anything higher, but rather merely a concrescence that issues into something new, a novel actual entity. Nevertheless, like Adorno’s negative dialectic, Whitehead's oscillating movement between disjunction and conjuction, many and one, prevents any loss of the moment of experience in the concept or in abstraction, and it refuses to accept a positive synthesis into a higher level as the final outcome. ${ }^{61}$

While for Adorno what requires him to return to and reflect upon concrete experience is his appeal to historical materialism, what requires Whitehead's return is his "reformed subjectivist principle." Whitehead reminds his readers in Process and Reality of the tension between the subjectivist principle and the sensationalist principle, restating them as follows: the subjectivist principle states that "the datum in the act of experience can be adequately analysed purely in terms of universals," while the sensationalist principle states that "the primary activity in the act of experience is the bare subjective entertainment of the datum, devoid of any subjective form of reception." ${ }^{62}$ The empiricists (Locke and Hume) accepted the sensationalist principle, but treated the subjectivist principle inconsistently at best, while Kant accepted the subjectivist principle, but rejected the sensationalist principle. Whitehead denies the appeal to

\footnotetext{
${ }^{60}$ Kraus, 42.

${ }^{61}$ Some Whitehead scholars would, however, point to a positive synthesis of all concrete fact in the consequent nature of God. The nature of this synthesis will be addressed in chapter seven.

${ }^{62}$ Whitehead, Process and Reality, 157.
} 
universals in the traditional definition of the subjectivist principle, or rather he redefines universals in terms of eternal objects such that the datum in experience is analyzed in the concrescence of an actual entity via conceptual prehension of an eternal object. Again Whitehead walks the difficult line between empiricism and rationalism, offering his "reformed subjectivist principle," which states that "subjective experiencing is the primary metaphysical situation which is presented to metaphysics for analysis," ${ }^{, 63}$ later restated as the idea that "apart from the experiences of subjects there is nothing, nothing, nothing, bare nothingness. ${ }^{.64} \mathrm{I}$ suggest that the reformed subjectivist principle further affirms the oscillation I cite as inherent in Whitehead's metaphysics in that it includes both an empirical moment and a rational moment, both a strong argument for the role of experience as the only content available for metaphysical reflection and an assertion that reception of such experience involves conceptual notions. Ultimately, subjective experience provides the only content for metaphysics; however, just as Adorno could not get rid of the objective moment as the second moment of his negative dialectic, Whitehead cannot do without the rational coordination of the eternal objects.

A second way in which Whitehead's speculative metaphysics resembles Adorno's own oscillation between metaphysical statements and critique of those statements may be witnessed from Whitehead's asymptotic approach to metaphysics, demonstrating the fact that his system cannot be labeled a closed system. Whitehead clearly endeavors to frame a "system of general ideas in terms of which every element of our experience can be interpreted, ${ }^{, 65}$ though he never claims to have succeeded in this endeavor such that the process of constantly evaluating and revising the system of general ideas might come to an end. The oscillation described above between concrete fact and moments of abstraction continues indefinitely as novel moments of

\footnotetext{
${ }^{63}$ Ibid., 160.

${ }^{64}$ Ibid., 167.

${ }^{65}$ Ibid., 3.
} 
experience continually present themselves for analysis. Stating precisely this fact, Whitehead remarks in Adventures of Ideas, "We cannot produce that final adjustment of well-defined generalities which constitute a complete metaphysics. But we can produce a variety of partial systems of limited generality." ${ }^{66}$ He thus assumes an asymptotic approach to metaphysics in that he aims at developing a robust metaphysical system capable of interpreting (and thus applicable to) every possible subjective moment (actual entity), but realizes he can never attain a completed system. The only possible promise of progress is that with each oscillation between fact and abstraction the system continues to approach (without every reaching) a completed system of general ideas. The reality is that Whitehead detests dogmatic finality, which itself would be a most egregious instance of the fallacy of misplaced concreteness. "Metaphysical categories are not dogmatic statements of the obvious; they are tentative formulations of the ultimate generalities." ${ }^{\prime 67}$ Therefore, Whitehead's system can only ever become a tentative system, asymptotically approaching the robust fullness of a completed system.

Given this asymptotic character of Whitehead's scheme, one simply cannot claim it to be a closed system.

On the other hand, I suggest that it also successfully avoids becoming a completely open system. As noted in the previous chapter, the problem with open systems is their voracious tendency to ingest anything and everything they encounter. In the edited volume Whitehead and Schleiermacher: Open Systems in Dialogue, Christine Helmer describes Whitehead's metaphysics as an open system (like Schleiermacher's) inasmuch as its claims "intra-worldly openness to motion, freedom, and life."68 Moreover, Helmer writes that openness within a

\footnotetext{
${ }^{66}$ Whitehead, Adventures of Ideas, 145.

${ }^{67}$ Whitehead, Process and Reailty, 8.

${ }^{68}$ Helmer, "Introduction," in Schleiermacher and Whitehead: Open Systems in Dialogue, ed. Christine Helmer, et al (New York: Walter de Gruyter, 2004), 6.
} 
system "affirms a world that can be experienced in its infinite diversity, so that it can be known." ${ }^{99}$ Helmer and others in the volume react against the type of closed systems that examine parts within a whole - a whole that is frequently conceived of as held within the mind of God (as in medieval Christian philosophical systems) or a whole that holds the world together with a sort of cosmic cohesion. ${ }^{70}$ Whitehead, on the other hand, articulates an open system in the eyes of Helmer and others because his system must be fluid enough to grow and change with the ingression of novel experiences. Whitehead's system does aim at being able to interpret every moment of experience; however, his system does not subsume experience into the oblivion of abstraction, as would be the tendency in a purely open system. In this sense, one can affirm Helmer's statement of Whitehead's system as "open" if open means only that the system involves a certain elasticity, enabling it to grown and change along with the rising tide of novelty. Yet at the same time, process metaphysics also resists becoming completely open because there is a system of general ideas in place to which each experience adds. Furthermore, Whitehead's fourth and twentieth categories of explanation support the notion that his system is not entirely open insofar as they demonstrate the interconnected nature of reality, the coordination inherent among actual occasions. The fourth category of existence reads as follows:

That the potentiality for being an element in a real concrescence of many entities into one actuality is the one general metaphysical character attaching to all entities, actual and non-actual; and that every item in its universe is involved in each concrescence. In other words, it belongs to the nature of a 'being' that it is a potential for every 'becoming.' This is the 'principle of relativity.

And in the twentieth category: "the determinateness and self-identity of one entity cannot be abstracted from the community of the diverse functionings of all entities." ${ }^{, 72}$ Both of these

\footnotetext{
${ }^{69}$ Ibid., 7.

${ }^{70}$ Ibid., 6.

${ }^{71}$ Whitehead, Process and Reality, 22.

72 Ibid., 25.
} 
categories affirm the notion that all actual entities have a background of information that is constituent of their becoming. In addition, entities cannot be abstracted from the metaphysical system as a whole and from their coordination within this system. We can neither catch a glimpse of the system as a whole (and so it is not a closed system), nor can we understand the "determinateness and self-identity" of individual actual entities outside of their relationships to those entities from which they emerge and which constitute their becoming and their being. Hence, Whitehead's speculative philosophy is not an open system in that it neither subsumes all experience into abstraction nor includes all experience in a completely uncoordinated and purely chaotic manner. To be sure, a little chaos must be present at points, and a little chaos even proves helpful, as we shall see in subsequent chapters; however, only coordinated chaos can finally remain.

Inasmuch as Whitehead's speculative philosophy resists classification as either an open or a closed system, I wish to further suggest that it displays a striking similarity to Adorno and Benjamin's notion of the constellation. His system of general ideas can indeed be viewed as that momentary, ever-changing coordination of events. Like Adorno's constellation, Whitehead's system most certainly expresses the relationships inherent among moments of experience within the system, since interconnectedness becomes one of the defining characteristics of process metaphysics. Additionally, the system of general ideas never concretizes itself into an immovable concept, but remains ever in the process of becoming. The general ideas, as the ontological principle reminds us, cannot become concretized as "reasons" (and hence, the system cannot be named a closed system). Only actual entities can be reasons, which implies that the reasons continue to grow and evolve; the system of general ideas does not itself provide reasons for becoming or actuality. 
Finally, just as Adorno's negative dialectic remains tenable in light of the events of the Holocaust, Whitehead's speculative philosophy too proves credible in the face of Auschwitz because of its ability to include all experience, even negative, deleterious experience; its asymptotic nature; and its refusal to endow every experience with positive meaning. Like Adorno's oscillation between metaphysical statements and their critique, Whitehead's oscillation between concrete experience and moments of abstraction to the system of general ideas ensures that one never loses experience in the abstract concepts and that one always returns to experience as the primary data on which the metaphysical system can and should be built. This oscillation additionally safeguards against dogmatic finality, maintaining an internal principle of revisability as novel moments of experience unfold, whether these moments are unimaginably horrific or overwhelmingly sanguine. Such a reading of Whitehead's metaphysics as tenable after Auschwitz and as containing a critique of dogmatic finality, inasmuch as it remains the oscillating form of a metaphysics in fall presented here, prove vital as we will attempt to read Whitehead alongside historical materialism in the process of building a theology of remembrance that neither abandons material reality (actuality) nor completely obviates appeal to transcendence. Additionally, as I discuss in subsequent chapters, Whitehead's abhorrence of dogmatic finality must extend to theological statements as well, and Whitehead himself has formulated such a critique. 


\section{Chapter 5: Whitehead and the Relation Among the Past, Present, and} Future

The previous chapter laid out the basic components of Whitehead's metaphysics before evaluating them in light of Adorno's critique of philosophical reflection after Auschwitz. Ultimately, I argued that Whitehead's philosophy remains tenable after the Holocaust because it involves the same sort of critical oscillation between experience and concept that one detects in Adorno's negative dialectic. This reading of Whitehead affirms the idea that rigid dogmatism must be avoided in both philosophy and theology, and this will prove more significant in the final chapter as I construct a theology of remembrance. As I hinted in the last chapter, Whitehead's metaphysics also uniquely correlates moments of experience among the past, present, and future, such that no experience can ever be said to be entirely lost to the past. This chapter will consider Whitehead's non-linear theory of time in order to move us back into an examination of the problem of coming to terms with the past and proffer the conclusion that an effacement of the past is neither preferable nor possible. Rather, the past must be worked upon (in Adorno's terms) or one must master the present (in Voegelin's terms) if one wants to successfully remember the past and guard against the repetition of baleful past events. Additionally, as he unfolds his speculative philosophy, Whitehead describes (in both Religion in the Making ${ }^{1}$ and Process and Reality ${ }^{2}$ ) how special experiences may be generalized, or given universal validity. In treating the Holocaust as a unique, paradigmatic event that (following Adorno and Voegelin) cannot be glossed over or simply dismissed as past, Whitehead's vision for how unique experiences may be generalized allows us to reconceive Whitehead's notions of the relation among past, present, and future from the purview of this deleterious event.

\footnotetext{
${ }^{1}$ Alfred North Whitehead, Religion in the Making (New York: Fordham University Press, 1996), 32.

${ }^{2}$ Whitehead, Process and Reality, 5-6.
} 
After describing Whitehead's extensive continuum and the connections among the past, present, and future, I will examine his notion of tragedy as described in Adventures of Ideas, noting the way in which tragedy must be maintained rather than effaced or dismissed. While I find problematic the idea that tragedy becomes a part of what he calls the harmony of harmonies, I will use his conception of tragedy as the means by which we keep the events of the Holocaust as past events from becoming integrated into present moments or concrescing actual entities, since integration implies a form of mastery of the past. Instead of proposing an integration of the past, and instead of allowing tragedy to be taken into the harmony of harmonies, I will suggest that tragedy remains indelibly an aspect of the past that must be remembered without being subsumed. These metaphysical insights also inform the way in which I will articulate a theology of remembrance as a theology that avoids positing integration of the past in a transcendent God. The next chapter on Whitehead's conception of the divine as dipolar will also aid in this regard.

\section{The Non-linearity and the Relativity of Past and Present}

Beginning with Science and the Modern World and extending into Process and Reality, Whitehead writes that the old Newtonian expression of space-time as an infinite series of individual units must be discarded. He is not alone in this assertion, since the birth of the relativity theory in physics altered the way in which physicists and mathematicians viewed theories of space and time. As opposed to considering space-time to be made up of "individually existing 'containers' which other actual things happen to occupy," ${ }^{3}$ Whitehead refers to spacetime as an extensive continuum. Whereas temporality was traditionally articulated in terms atomic units - meaning individual, serial moments - the extensive continuum denotes an expression of time as extensive over a certain duration, giving it a wider expression than the

\footnotetext{
${ }^{3}$ Hosinski, 133.
} 
merely atomic unit. Time along the extensive continuum can be infinitely divided into whatever quantities are necessary for analysis (and not just into predetermined units of uniform measurement). The extensivity of time indicates a relational aspect among moments of the past, such that the extensive continuum becomes "one relational complex in which all potential objectifications find their niche." ${ }^{4}$ Whitehead still writes of present and concurrent actual entities as displaying an atomicity, since they can be analyzed in terms of the unity of their own concrescence; however, the extensive continuum applies to all actual entities once they have reached satisfaction and become superjects for subsequent actual entities. ${ }^{5}$ As superjects and as displaying extensive and relational qualities, they influence the becoming of subsequent actual entities. The extensive continuum denotes the space-time in which potential objectifications are possible, and it displays the aspects of "infinite divisibility and unbounded extension, containing no singularities, no privileged 'places,' no asymmetrical relations..." ${ }^{\text {Ot }}$ Out of this extensive continuum arises the wealth of objects available to the present concrescence of an actual entity. The phases of prehension in a concrescing actual entity order the relevant past such that the disjunction of the potential objectification of the continuum becomes unified into the singularity of the present entity. In this way, the extensive continuum may be viewed as a web-like structure that applies not only to the welter of the objective past, but also denotes the relationality of the singularity of present and concurrent actual entities. The extensive continuum "stretches out the event horizon of all that has become over all becoming, creates objectivity and facticity, efficacious causal force and presence within that which is coming,"7 and thereby includes the becoming relations of the present as well as the "place" (lacking precise spatial location) in

\footnotetext{
${ }^{4}$ Whitehead, Process and Reality, 66.

${ }^{5}$ Ibid.

${ }^{6}$ Kraus, 65 .

${ }^{7}$ Roland Faber, God as Poet of the World: Exploring Process Theologies (Louisville, KY: Westminster John Knox Press, 2008), 78.
} 
which potential future occasions might themselves become (and become themselves). In this sense, it manifests itself as the locus out of which creativity draws past occasions for the process of constructing a next, novel occasion. As Roland Faber notes, "From within this 'extensive continuum' as the past, creativity actualizes new events, which in perishing enrich the continuum and structure it anew as a whole." ${ }^{\prime 8}$ Faber makes clear that the extensive continuum is not without structure - it is not a field of pure or mutual immanence, which Faber instead reads Whitehead as likening to Plato's receptacle, the khora, but rather it is the structured yet disjunctive past and relationality of the concrescing present out of which the future becomes. ${ }^{9}$

Given this relational and relative notion of time, it is as possible to say in Whitehead's metaphysics that the past is relative to the present as it is to say that the present is relative to the past. Taking the first half of this statement, the disjunctive diversity of antecedent actual entities becomes the real potentiality present for inherence into the becoming of each present actual entity. The antecedent actual entities available to the concrescence of each subsequent actual entity are "relative to some actual entity, taken as a standpoint whereby the actual world is defined." 10 Thus the disjunctive diversity of the past is relative to the present in that this diversity continues to change and grow as present entities continue to reach satisfaction and perish into the data of the past. In this manner, one can say that the past is never the same for any two actual entities: "no two actual entities originate from an identical universe..." result the past is relative to that present moment which receives it as past. Likewise, the present is relative to the past because "[n]o actual entity can rise beyond what the actual world as a

\footnotetext{
${ }^{8}$ Ibid.

${ }^{9}$ This difference is noted in God as Poet of the World, 78-79, as well as in a forthcoming chapter, "The Mystical Whitehead," in a festschrift to Joseph Bracken. Here Faber seems to correlate creativity and the khora, as opposed to the extensive continuum and khora.

${ }^{10}$ Whitehead, Process and Reality, 65.

${ }^{11}$ Ibid., 22.
} 
datum from its standpoint - its actual world — allows it to be." ${ }^{\prime 12}$ The actual entity in its mode of concrescence shapes itself, brings itself together, out of the wealth of the data of the past, which supplies its potentiality. However, it concresces only out of this potentiality and only by ordering its actual past, which is its actual world. At this point we are reminded of the ontological principle, which states, "there is nothing which floats into the world from nowhere."13 An actual entity cannot include in its concrescence some aspect that did not already exist, and hence the present (comprised of the currently concrescing actual entity) is relative to that past out of which it arises.

Of utmost importance for this work is the notion that the past remains always available as objective data to be prehended (either positively or negatively) by subsequent actual entities, along with the twofold conception that the past structures the present and the present structures the past (inasmuch as it receives the past from its own particular viewpoint at a particular moment). As we shall consider below, the past is not solely determinative of the present, though the influence of the past undoubtedly manifests itself in each unfolding moment. Whitehead describes precisely how this occurs as he defines the phrase "perception in the mode of causal efficacy." In his theory of prehensions he enumerates two modes of perception: perception in the mode of causal efficacy and perception in the mode of presentational immediacy, both of which are fused together by symbolic reference. Presentational immediacy signifies sense perception, and with this phrase Whitehead aims at indicating "that sense perception appears to present to us the contemporary world in its relations to our standpoint." 14 Perception in the mode of causal efficacy, on the other hand, denotes non-sensuous perception; it is perception of the objective moments of the past. Symbolic reference then indicates the whole perceiving process

\footnotetext{
12 Ibid., 83.

${ }^{13}$ Ibid., 244.

${ }^{14}$ Hosinski, 49.
} 
and becomes the interpretation of sense perceptions (causal efficacy taken with presentational immediacy). ${ }^{15}$ In the mode of causal efficacy the actual entity "feels" the objects of the past as they themselves "felt" in their own subjective becoming. Again, feeling and emotion here do not refer to cognitive emotions, but rather they imply a vector character, meaning that what was "felt" in the past, or what was perceived, propels itself into subsequent moments (the superjective nature of each actual entity). Perception in the mode of causal efficacy is thus, "always a receiving from the past, the past of a split-second ago."16 Yet causal efficacy can also carry with it the content of past moments not directly antecedent to the presently concrescing actual entity. Whitehead names memory as an example of perception in the mode of causal efficacy, "For memory is perception relating to the data from some historic route of ultimate percipient subjects..."17 In other words, perception of the antecedent occasions along a "historic route" or a series of sequential occasions may be termed memory, since the subsequent occasions in this chain continue to receive the content of the past, feeling the past as it was felt subjectively.

Thus, perception in the mode of causal efficacy marks the way in which the present receives the past, and it indicates how the past propels itself into the future. This vector nature of actual entities proves quite important for Whitehead as it ensures a certain amount of continuity as well as a creative advance in the unfolding of the future. "The creativity of the world is the throbbing emotion of the past hurling itself into a new transcendent fact." ${ }^{\prime 18}$ The new fact or new actual entity can be said to be transcendent in that it transcends the actual world from which it arises; it provides that actual world with some new fact beyond the settled facts it gathers

\footnotetext{
15 Ibid., 50.

${ }^{16}$ Ibid., 52.

${ }^{17}$ Whitehead, Process and Reality, 120.

${ }^{18}$ Whitehead, Adventures of Ideas, 177.
} 
together in its becoming. Yet, it acquires the emotion of the past and retains aspects of the past as it launches itself, as a superject, into the future.

\section{Creativity, Novelty, and the Potentiality of the Future}

Whitehead remarks in Adventures of Ideas that the immanence of the past in the present is sufficiently evident from the subject/object relation of entities, yet the immanence of the future in the present is not as immediately clear. "The past has an objective existence in the present which lies in the future beyond itself," and as noted above this follows from the fact that each actual entity grows together as a subject and then perishes as an object to be prehended by future actual entities. Up to this point we have discussed only the prehension of the objective past, leaving aside the prehensions of eternal objects. The latter comprises the mental pole within the stages of concrescence, while the former may be termed the physical pole. In the previous chapter I referred to these two types of prehensions as physical prehensions and conceptual prehensions. They are, respectively, prehensions of the actual world as it makes itself known to the actual entity as the antecedent occasions comprising its past and prehensions of eternal objects. If we were to leave off our discussion after only describing the physical pole of a concrescence, one would be left with the notion that the past is primarily responsible for determining how an actual entity comes into being. However, this is not the case, since creativity and the potentiality of the future play an equally significant role in the composition of the present moment.

Whitehead articulates the functions of creativity and the future in Adventures of Ideas when he describes the process of concrescence as "a passage from re-enaction to anticipation."19 The passage can also be seen as a "transition between two worlds, the immediate past and the

\footnotetext{
${ }^{19}$ Ibid., 192.
} 
immediate future. ${ }^{, 20}$ Re-enaction, the origin from which this passage begins, refers to the primary phase of concrescence in which the actual entity physically prehends antecedent occasions. However, the present does not merely re-enact the past, and so Whitehead describes an intermediate phase within this transition from immediate past to immediate future as "constituted by the acquisition of novel content, which is the individual contribution of the immediate subject for the re-shaping of its primary phase of re-enaction into its final phase of anticipation. ${ }^{21}$ This intermediate phase includes conceptual prehensions, which are integrated with physical prehensions and "thus yield propositions concerning the past." ${ }^{, 2}$ Without diverting toward a lengthy discussion of propositions in Whitehead's philosophy, we can concisely say that propositions are "particular facts in a potential pattern," 23 or potential stories about the world. Measuring the truth or falsehood of a proposition is, for Whitehead, far less important than whether or not the proposition becomes a lure for feeling, whether or not it invites novelty into the concrescence of an actual entity. The integration of conceptual with physical prehensions, issuing into potential statements (propositions) about that actual entity, involves the principle of creativity. Recalling the explication of creativity in the previous chapter, Whitehead writes in Process and Reality that creativity is "that ultimate principle by which the many, which are the universe disjunctively, become the one actual occasion, which is the universe conjunctively."24 Creativity denotes this intermediate phase in the passage from re-enaction to anticipation. Elsewhere, Whitehead writes that "creativity is the actualization of potentiality, and the process of actualization is an occasion of experiencing. ${ }^{25}$ In both instances creativity denotes the

\footnotetext{
${ }^{20}$ Ibid.

${ }^{21}$ Ibid.

${ }^{22}$ Ibid.

${ }^{23}$ Whitehead, Process and Reality, 194.

${ }^{24}$ Ibid., 21.

${ }^{25}$ Ibid., 179.
} 
process whereby the moment of experience is actualized or in which the actual entity comes together as a unity, and it ensures that the actual entity is novel relative to its antecedent occasions.

Before going further, let me make a brief note regarding potentiality and actuality in Whitehead's speculative philosophy. As opposed to Aristotelian and substance-based metaphysics, potentiality or possibility can no longer be associated with matter, and the real with form. Instead, the associations are reversed, such that the "forms" or eternal objects are nonactual pure potentials. They only enter into actuality when they inhere in a particular actual entity as a part of that occasion's concrescence and as providing value and intensity to the becoming occasion. $^{26}$ Similarly, the content of the past and the possibility inherent in the future can be said to be potential, since they have either ceased to be actual or have not yet become actual. Actual entities, on the other hand, while not composed of inert matter, are the only actual things in the world. Perhaps in line with the traditional version of potentiality, Whitehead does consider potentiality as present only within objects (and not within subjects), in the sense that eternal objects, the data of the past, as well as the anticipation of the future ${ }^{27}$ are objects presenting themselves for inherence in the present subject. "Possibilities in and of themselves have the status of 'pure objects' for the realization of events; that is, in no way can subjectivity be attributed to them, and their objectivity is pure abstraction from the process itself." 28 Moreover, Faber notes that Whitehead paradoxically defines potentiality as "the presence of the timeless within the process [of the becoming of the world]," so that the potential is not temporal, but is that aspect of the timeless within the temporal world of becoming. ${ }^{29}$ The potential as timeless

\footnotetext{
${ }^{26}$ Roland Faber, "The Divine Manifold" (forthcoming 2012), chapter 16.

27 "Thus the future is to the present as an object for a subject," Whitehead, Adventures of Ideas, 194.

${ }^{28}$ Faber, God as Poet of the World, 86.

${ }^{29}$ Ibid.
} 
derives from the fact that eternal objects, the objectivity of the past, and even the possibility of the future remain outside of time - the past by virtue of its inclusion in the extensive continuum, eternal objects by virtue of their derivation from the primordial nature of God (an aspect to be discussed in the following chapter), and the future by virtue of the fact that it has not yet become or entered into temporality.

Creativity in Whitehead's speculative philosophy is that activity which takes this potentiality and makes it actual. "Creativity refers to the ground of events and to the ultimate principle of cosmology, answering the most fundamental question of 'why,' namely, why there is something rather than nothing. ${ }^{, 30}$ In Science and the Modern World he refers to it as the "underlying activity," or the "substantial activity," meaning not that creativity is substance, but that it can be likened to the primary substance insofar as it "cannot be characterized because it is the source of all characters and, as such, the ultimate subject of predication." ${ }^{31}$ Creativity manifests itself in the act of becoming, but in itself it is neither actual nor potential. "The underlying activity does not 'exist,' for to exist means to be determinate; yet it is the ground for all determinacy. Neither is it possible, for it likewise grounds possibility.",32 Whether it is potentiality in the form of eternal objects, in the form of the multiplicity of the past, or in the form of the possibility of the future, creativity ushers potentiality into actuality, thus introducing novelty into the actual becoming occasion. In fact, when Whitehead introduces creativity as the category of the ultimate, he terms it the "principle of novelty," writing that an actual occasion "is a novel entity diverse from any entity in the 'many' which it unifies. Thus 'creativity' introduces novelty into the content of the many, which are the universe disjunctively." ${ }^{33}$ Novelty signifies

\footnotetext{
${ }^{30}$ Faber, God as Poet of the World, 76.

${ }^{31}$ Kraus, 36. Cf. Faber, God as Poet of the World, 76-77.

32 Ibid.

${ }^{33}$ Whitehead, Process and Reality, 21.
} 
another vital principle in Whitehead's speculative philosophy_vital in the twofold sense of bearing utmost importance and of endowing the world with vitality or liveliness. "Without the 'novel,"” Faber writes, "there can be no events, no becoming and perishing, only rigidity, and instead of process only the stasis of a relational structure. ${ }^{34}$ When Whitehead refers to novelty he does not mean merely a variation of the old, but rather he uses this notion to make space for the radically new, for that which in no way can be prefigured from past events. ${ }^{35}$ This is not to say that every actual entity is radically new, since this would result in a wholly disjunctive world, the true result of an entirely open system; though Whitehead's notion of novelty succeeds in allowing the radically new to be coordinated within his metaphysical scheme. This understanding of the entrance of novel events into actuality has specific and significant bearing on this work, which seeks to critique the idea that one can ever come to terms with the deleterious moments of the past. If the Holocaust can be considered as a whole series of harmful events that constituted something radically new, then what does it mean that these events too can be coordinated within the system of general ideas that is Whitehead's metaphysical scheme? It is to this particularly demanding and unsettling question that I will turn in the next section.

Novelty as the radically new comes to the present moment from the principle of creativity discussed above and from an anticipation of the future. Returning to Whitehead's description of the passage from re-enaction to anticipation, we can now determine that anticipation means a realization of the possibility of the future in the present. The present subject reaches satisfaction and perishes, itself becoming something for the future as now objective datum in the past. Future moments will then continue this process of the passage from re-enaction to anticipation by prehending this subject that has become an object, including prehension of its "patterns of

\footnotetext{
${ }^{34}$ Faber, God as Poet of the World, 82.

${ }^{35}$ Faber, God as Poet of the World, 83.
} 
activity." ${ }^{36}$ As anticipation, the occasion realizes its influence beyond itself as objective fact for the future: "Thus the self-enjoyment of an occasion of experience is initiated by an enjoyment of the past as alive in itself and is terminated by an enjoyment of itself as alive in the future. ${ }^{, 37}$ In this sense of anticipation, Whitehead asserts that the future is immanent in the present as the present occasion forms propositions concerning its own influence in the future (anticipatory propositions). Nevertheless, he is clear to remind us that future occasions cannot be said to exist. Rather, "The anticipatory propositions all concern the constitution of the present occasion and the necessities inherent in it. This constitution necessitates that there be a future, and necessitates a quota of contribution for re-enaction in the primary phases of future occasions. ${ }^{\text {38 }}$ Thus, the passage from re-enaction to anticipation begins again once the present subject reaches satisfaction and perishes into objective fact. But within the concrescing moment the phases of re-enaction and anticipation denote the ways in which both past and future may be said to be immanent in the present - the past by means of its physical prehension in the present actual entity and the future by means of the present actual entity's realization of its objectivity beyond itself in the future, a realization of its own transcendence in excess of the actual world constituted by objective past. Articulating the present as the conjunction of the real potentiality of the past and possibility of the future, Faber affirms that "it is within a becoming event itself that both past and future come together as the potential for realization; as such it is the presence of both past and future." ${ }^{39}$ Whitehead himself goes further than this to say, "an occasion arises as an effect facing its past and ends as a cause facing its future. In between there lies the teleology of the Universe." The teleology inherent in the present occasion is nothing other than

\footnotetext{
${ }^{36}$ Whitehead, Adventures of Ideas, 193.

${ }^{37}$ Ibid.

${ }^{38}$ Ibid.

${ }^{39}$ Faber, God as Poet of the World, 86.
} 
the principle of creativity, that which leads the world continually from disjunctive many into conjunctive unity.

In its capacity to be anticipated in the present, the future expresses its immanence in the present as an object to the present subject. Briefly stated above, the future, like the past (though in a different manner than the past) can be labeled an object: "the future is to the present as an object for a subject.. ${ }^{, 40}$ The future as object differs from the past as object in that there are no fully realized occasions in the future. Whereas the past constitutes real potentiality because of its past existence and its individual togetherness as a perished occasion, the future, lacking the actual togetherness of fact, can be termed (as Faber names it) pure possibility. ${ }^{41}$ Yet the present anticipates structure in the future, even as it denotes pure possibility:

What is objective in the present is the necessity of a future of actual occasions, and the necessity that these future occasions conform to the conditions inherent in the essence of the present occasion. The future belongs to the essence of present fact, and has no actuality other than the actuality of present fact. But its particular relationships to present fact are already realized in the nature of the present fact. ${ }^{42}$

This lengthy quote from Adventures of Ideas signals both a notion of the future as pure possibility, insofar as it lacks actuality, as well as the understanding that the future must in some way comply with the present fact. Future actual entities will take in the present and conform to the present in their own novel ways, yet the present, which becomes past for the future, can never be discarded. The present realizes in its process of concrescence its own future beyond itself, which holds both pure possibility and inherent limitation by means of the way in which the present becomes. Whitehead names two phases in the mental pole of concrescence: conceptual reproduction in which the relevant eternal objects from the immediately antecedent occasion are felt (prehended), and conceptual reversion in which relevant alternatives are felt, leading to

\footnotetext{
${ }^{40}$ Whitehead, Adventures of Ideas, 194.

${ }^{41}$ Faber, God as Poet of the World, 83.

${ }^{42}$ Whitehead, Adventures of Ideas, 195.
} 
greater intensity and contrast (two ideas that aid in the production of novel content). These two phases, conceptual reproduction and conceptual reversion, maintain the balance described in Adventures of Ideas between the future as pure possibility and the necessity of the future to conform to its immediate past: "reversion is always limited by the necessary inclusion of elements identical with elements in feelings of the antecedent phase." ${ }^{.3}$

To reiterate, this relationship of the future to the present thus arises from the present's anticipation of its own relationships to the future, which complies with the statement that the future is just as immanent in the present as the past, though in the different manner demonstrated here. When Whitehead first begins to suggest this idea in the second chapter of Process and Reality, he already endows the notion of the future as immanent in the present with a tinge of ethical import in his own nonchalant way, as he is wont to do. "The greater part of morality hinges on the determination of relevance in the future. The relevant future consists of those elements in the anticipated future which are felt with effective intensity by the present subject by reason of the real potentiality for them to be derived from itself." ${ }^{44}$ Morality hinges on the determination of relevance in the future because the way in which an actual entity becomes in the present not only constitutes what that actual entity is (Whitehead's principle of process), but it also shapes the way in which the future will unfold. The becoming of an actual entity can be said to involve moral decisions because that entity has already felt an anticipation of its relevant future. Each moment is already aware of aspects of its future and consequently does not make decisions in the dark, so to speak. To generalize from this position and recapitulate our discussion, decisions made in the present receive influence from the past as well as from anticipation of future decisions. Inasmuch as nothing decides apart from this realization of its

\footnotetext{
${ }^{43}$ Whitehead, Process and Reality, 249.

${ }^{44}$ Whitehead, Process and Reality, 27.
} 
relevant future, each decision involves moral determinations by virtue of the fact that it glimpses its own influence beyond itself. In the next section I will draw correlations from Whitehead's assertions that the past and future are immanent in each present moment to Adorno and Voegelin's critiques of the idea of coming to terms with or mastering the past, and this ethical dimension of the immanence of the future in the present plays a specific role in denoting how remembrance of the past (the prehension of past occasions hurtling themselves forward as ripples through time from the past, through the present, and into the future) fosters not only ethical but also theological imperatives.

\section{Tragedy and the Universality of Unique Events}

To be sure, one cannot consider the Holocaust as a single event. Rather, as viewed from either Whitehead's speculative philosophy or some other event ontology, the Holocaust would have to be understood as series upon series of events or occasions occurring throughout (but certainly not limited to) the course of National Socialist control in Germany. Therefore, we are presented with the impossibility of ever prehending or perceiving the Holocaust qua Holocaust. On the other hand, individual past experiences of or relating to the Holocaust are available to each present moment in its mode of becoming. By virtue of this potential availability (which is never a presence in the sense of an immediate presence of the entirety of the events), Whitehead does present a way in which moments of the Holocaust may be generalized so as to come to bear in a wider sense upon the present and future and, more significantly, upon occasions not immediately subsequent to the original experience.

Whitehead writes in Religion in the Making of how special religious experiences may gain a wider audience than solely that person for whom the experience was immediately present. Faber relates Whitehead's discussion of religious experience in what Whitehead terms "rational 
religion," or the latest phase (of which we are aware) in the evolution of religion from ritual and mythological religion to "the recognition of universal connectivity," which he sees as a later development in religious consciousness. ${ }^{45}$ The connectivity of this later phase of development involves, as Faber notes, a reciprocal movement toward both solitariness and solidarity, such that religious intuition becomes the "universal mediation of uniquely experienced events." events themselves express a solitariness as they are uniquely experienced by a single individual; moreover, this experience "cannot be conceptualized completely, but is bound to the uniqueness of the experienced over against all conceptual generality."47 Whitehead always refrains from dissolving experience into something conceptual, despite the necessity of generalizing so as to coordinate the experience within the metaphysical scheme. Even within the generalizing move, the experience remains as unique fact. On the side of solidarity, however, unique experiences must make themselves communicable to others, since religion does not rest merely in individual intuition but positions itself as a "central element in a coherent ordering of life." unique, individual religious intuition must be universally mediated so as to be accessible beyond the original receiving individual. Whitehead argues for this universalization explicitly in Religion in the Making: "religion claims that its concepts, though derived primarily from special experiences, are yet of universal validity, to be applied by faith to the ordering of all experience."49 Without entirely conceptualizing the experience or giving preference to the conceptualization over above the unique experience itself, the experience must be universalized so as to have universal meaning and validity.

\footnotetext{
${ }^{45}$ Roland Faber, "On the Unique Origin of Revelation, Religious Intuition, and Theology," in Process Studies 28, no. 3-4 (1999): 196.

${ }^{46}$ Ibid. Emphasis is in the original text.

${ }^{47}$ Ibid.

${ }^{48}$ Whitehead, Religion in the Making, 31. Cf. Faber, “On the Unique Origin,” 197.

${ }^{49}$ Ibid., 32.
} 
Faber names this memoria or anamnesis and asserts that "only singular events have universal meaning"-meaning that subsequent occasions prehend events or past occasions and not abstract concepts. These singular events become universal by virtue of their repetition in subsequent events. Such repetition occurs as a re-presenting of the unique event in its integrity as event within subsequent moments: “'Repetition' is the universal effectiveness of the singular revealing events within their concrete history. ${ }^{, 50}$ Through repetition the singular events maintain their integrity by being represented in their concrete history, not abstracted from their concrete origin into a conceptualization. Yet they also take on universal validity and import by transcending themselves and becoming immanent in the present. Faber refers to the repetition of the singular event now universalized as memoria or anamnesis, remembrance or recollection, and I think that these terms better denote the way in which singular events of the past are represented in the present. Their repetition is not mere rote repetition, but rather a remembrance of the past in the present as having validity and import for the present. As mentioned above, Whitehead himself names perception in the mode of causal efficacy a type of memory. His evocation of memory recurs in Adventures of Ideas in a similar manner. Here he describes Hume's assertion that "the force and liveliness of one occasion enter into the character of succeeding occasions," remarking that what Hume really notes in this instance is the immanence of the past in the present and future. ${ }^{51}$ Slightly later, Whitehead comments on the perishing of an actual entity after it has reached satisfaction. Rather than terming this perishing a loss, he highlights the necessity for the moment to perish in order for it to be prehended as past datum in future moments; perishing "is how the past lives in the present. It is causation. It is memory." From these passages, and in line with Faber's own thoughts, comes a clear view of the

\footnotetext{
${ }^{50}$ Faber, "On the Unique Origin," 199.

${ }^{51}$ Whitehead, Adventures of Ideas, 184.

${ }^{52}$ Ibid., 237.
} 
immanence of the past in the present and future as a form of remembrance or recollection. Proceeding further, singular events universalize themselves by virtue of their superjective character derived from the final phases of concresence. They become, as alluded to earlier, singular events hurtling themselves forward through time in order to take on universal significance as perpetual remembrance of the unique singular event itself. In this sense, by viewing the process of universalizing via the vector character of the singular event, rather than as a merely passive reenactment of the event in the present and future, the singularity of the past maintains control of its own remembrance instead of being controlled by the universalizing process of the present and future events: "its own constitution [as an actual entity] involves that its own activity in self-transformation passes into its activity of other-formation." ${ }^{, 53}$ Thus, this process of universalization does not master the past as adopting the position of controlling (and potentially redactive) present or future, but it retains its own singularity re-presented in the present and future. When the singular past event universalizes itself, it gains significance for all subsequent occasions such that its function as remembrance serves to order the way in which these future occasions come together as moments of experience. It provides an ordering principle to the becoming of the future moments (and here we see a precursor from Whitehead himself of the theological norm of remembrance to be introduced in the concluding chapter). Whitehead describes the role of religion and religious experience in precisely this manner: "religion claims that its concepts, though derived primarily from special experiences, are yet of universal validity, to be applied by faith to the ordering of all experience." ${ }^{.54}$ Through repetition as remembrance, religion in this sense assumes an ordering role for all experiences that follow.

\footnotetext{
${ }^{53}$ Ibid., 193.

${ }^{54}$ Whitehead, Religion in the Making, 32.
} 
What I intend with this consideration of the way in which singular events may be universalized is the illumination of a means for the events of the Holocaust to bear universal validity for present and future occasions. Universal validity does not mean that one can never move beyond these past events or that one is always entirely absorbed in the events. Rather, it means that the events continue to influence the becoming of the present and future through their universal validity, which comes about by a repetition that I now refer to as remembrance. Insofar as the events of the Holocaust can be universalized, one gains an understanding of how these events come to bear in the sense of a moral imperative upon all subsequent occasions. Indeed, this might be the way in which categorical imperatives find their place in Whitehead's metaphysics - not as dogmatic statements, but as generalizations within the constellation that comprise metaphysical reflection and that remain ever capable of critique and revision. Thus, via this universalization of events of the Holocaust, Adorno's new categorical imperative receives a metaphysical shot in the arm. If each new moment within the unfolding of world history contains a remembrance of the Holocaust, then perhaps we may be able to hold to the dictum that "Auschwitz should not be repeated and that nothing like it should ever exist again." 55 Unfortunately, from the perspective of the early twenty-first century we know this has not been the case. Wreckage continues to pile upon wreckage until the whole earth reeks with the stench of human destruction. Nevertheless, we should not forego the aim at remembrance merely because we often fall into forgetfulness; rather, recurrent forgetfulness lends in every moment a new lease to the struggle for remembrance.

While some might hold that the universalization described above could be viewed as mastery of the past because it abstracts from individual experience, resulting in a static conceptualization of the experience, I deny this claim on the following grounds. First, as Faber

\footnotetext{
${ }^{55}$ Adorno, Metaphysics, 116.
} 
asserts, the process of universalizing singular experiences does not dissolve the event completely into a conceptualization. Quite the contrary, the events must remain singular events so as to be repeated and remembered in subsequent events. While they do alter the theoretical constellation that makes up the metaphysical scheme, for Whitehead experiences can never be analyzed away into the system. Rather, as elucidated in the previous chapter, one starts from experience, generalizes $^{56}$ via moments of abstraction to the system of general ideas, then returns again to concrete experience in order to test the applicability of the system, now revised so as to be able to interpret the original moment of experience. Likewise, the process of universalizing singular events never seeks its fulfillment in abstraction, but aims at illuminating subsequent experience by means of the universalized event. The universalization involves a moment of abstraction in that the event reaches toward generalization insofar as it becomes a part of the constellation by means of which one interprets the world. Yet, the event must also maintain its singularity without which it could not be included as objective datum in subsequent events. Thus, universalization does not equal mastery of the past, since it does not result in a final concretization of the past such that one can say the past has been overcome by subsuming it into a conceptualization. Additionally, and perhaps more importantly, the process of universalization described here does not, I contend, remove the uniqueness from events of the Holocaust. Rather, it is only by means of the uniqueness or singularity of these events that they can be universalized in the first place. In Whitehead's system, endowing the singular with universal validity does not erase the uniqueness because the event becomes universal only by repeating or remembering the

\footnotetext{
${ }^{56}$ I must note that general and universal are not the same. Universal means applicable to all items under a certain category, whereas general means applicable to most (but not necessarily all) items. However, when Whitehead discusses the process of generalization in order to correlate moments of experience to the system of general ideas, he refers to all, and not just most, moments of experience. It must be a system of general ideas in terms of which all experience can be interpreted. As a result, I do not think it an error to describe this process of generalization when discussing how singular events may be universalized.
} 
event (continuing to prehend the event) in its concrete history as unique fact. Moreover, the above discussion of the active nature of the universalizing singularity-hurtling itself through time - denies any power of control over the content of the remembrance by the present and/or future, thereby resisting any an recourse to mastery of the past and instilling instead the possibility of mastering the present through remembrance as the universalization of the singular event(s).

Along these lines, Whitehead's use of the term integration in his explication of the passage from re-enaction to anticipation is problematic for the same reasons. Integration of the past experiences of the Holocaust points to mastery of the past, if by integration one intends that the past has been included and thus "dealt with." In my interpretation of Whitehead, this is not at all what he intends; nevertheless, I agree that the term is problematic and could lead one to assume that because the past is immanent in the present then the present moment (once it passes) has also sufficiently dealt with the past such that one need not carry on with remembering the past in the future. Contrary to this version of mastery of the past, I believe that what Whitehead promotes is a process of recollection of remembrance over and above one of integration, and to posit this I must read Whitehead against himself in at least two instances.

First, the integration described in the concrescence of each actual entity in the transition from re-enaction to anticipation yields propositions, which are themselves only potential stories about the world, and so there is no sense in which this integration denotes a full and final integration of the past. Furthermore, there is no means by which an actual occasion's inclusion of some past moment of experience depletes the past of this moment of experience. The past can never be used up, so to speak, but always remains available as data to be taken into account by future occasions irrespective of how many times the same data has already been included. In 
fact, in remembrance by means of universalization this is exactly the goal- to continue to include aspects of the past in the process of becoming. One could also charge that the final product of concrescence, known as satisfaction, in which the actual entity comes together as a unity, however brief, implies some form of integration of the past. Yet, if this is the case, it is not a mastery of the past insofar as the oscillation between objective past and subjective present—being and becoming, fact and possibility—prevents any final stabilization of past into permanent concretion. Instead, the present in turn becomes objective datum for the next present occasion. Perhaps this is analogous to Adorno's third moment of the dialectic. Though he doesn't completely abandon the notion of synthesis, he denies any possibility of a positive synthesis aiming toward a higher synthesis. Whitehead likewise avoids any integration that leads toward a higher level, but rather at the very point of integration the subjective moment ends and returns to objective datum as past experience capable of being included in future experience. Ultimately, contrary to reading mastery of the past into the Whitehead's scheme, I see the process of concrescence, in which the past and future are immanent in the present, as the means by which each moment masters the present. Each present occasion subjectively draws from the past and anticipates its role in the future as it decides for itself how it will come together. Thus, the way in which I read Whitehead's transition from re-enaction to anticipation does not constitute mastery of the past and thereby avoids Voegelin's ever present (and necessary) critique.

Second, a close examination of Whitehead's discussion of tragedy in the latter pages of Adventures of Ideas further signals a denial of any form of mastery of the past. Here I stress the words "close reading," since a cursory reading of Whitehead on this subject would undoubtedly leave one with the impression that all tragedy receives its place in the harmony of harmonies that 
Whitehead calls Peace. I do not think this to be the case, and I hold that a thorough exegesis of the text proves it is not. In the last part of Adventures of Ideas, Whitehead philosophizes on the meanings of Truth, Beauty, Adventure, Art, and Peace, contending that the joint relation among these constitutes civilization. ${ }^{57}$ His musings on civilization underline a processual understanding of history and of the movement of civilization; however, as previously suggested, his version requires a continually unfolding process without definite end. The universe lacks a fixed trajectory toward which it aims for some ultimate denouement. Civilization rather moves with the rhythmic pulse of creativity toward the greater production of novelty, which in turn issues into higher valuations of Truth, Beauty, Art, Adventure and Peace. Each of these terms refers to a specific notion in Whitehead's philosophy, which I will briefly unpack — though, like in his explication of his speculative philosophy, definitions of terms overlap such that nothing can be cut out of the system in which it finds its meaning. Truth refers to the conformation of appearance to reality, which means the conformation of the subjective "togetherness" in the actual occasion that arises following the mental phase of each occasion (appearance) to the objective past (as reality). ${ }^{58}$ Beauty is the "mutual adaptation of the several factors in an occasion of experience," such that the various prehensions involved in a given concrescence do not inhibit each other but lead to the increase of novelty by producing new contrasts among objective data of the past. ${ }^{59}$ In order to highlight these contrasts, Beauty necessarily includes an amount of discord: "the contribution to Beauty which can be supplied by Discord—in itself destructive and evil - is the positive feeling of a quick shift of aim from the tameness of outworn

\footnotetext{
${ }^{57}$ I will continue to capitalize each term to signify that I am using Whitehead's understanding of the term, since each means something specific within his philosophy.

${ }^{58}$ Whitehead, Adventures of Ideas, 210, 211, 241.

${ }^{59}$ Ibid., 252.
} 
perfection to some other ideal with its freshness still upon it." ${ }^{\prime 60}$ Thus, discord, while in itself evil, aids in the production of Beauty by providing the contrasts necessary for novelty, halting the sequence of rote repetition, or ensuring that the "tameness of outworn perfection" does not continue indefinitely. Whitehead glosses on the outworn perfection that became the downfall of ancient Greek civilization, as it failed to continually adapt itself or transcend its own perfected past. Perfection, therefore, while something for which to aim, once attained becomes an instrument of mere repetition. Adventure, then, is "the search for new perfections."

In articulating the interplay of discord and Beauty, Whitehead introduces the term evil. Displaying the harmful, destructive power of discord, evil can be understood as the realization of "destruction as a dominant fact in the experience." ${ }^{62}$ Essentially, while evil in and of itself must be viewed negatively, as it can result only in destruction, when evil and Beauty combine to produce basic disharmonies in the process of an occasion's becoming, Whitehead sees this as a fortunate means of avoiding the rote repetition of stasis. While harmony among various factors might be preferable in the constitution of an actual entity, disharmony also serves to aid in the increase of novel becomings, and according to Whitehead evil actually aids in the process. Whitehead writes: "The objective life of the past and the future in the present is an inevitable element of disturbance. Discord may take the form of freshness or hope, or it may be horror or pain." ${ }^{\circ 3}$ What matters, whether an experience evokes harmony or disharmony, is the strength of the experience. Intense experiences may include either, despite the fact that "[h]armony is bound up with the preservation of the individual significance in detail, and Discord consists in its

\footnotetext{
${ }^{60}$ Ibid., 257.

${ }^{61}$ Whitehead, Adventures of Ideas, 258.

${ }^{62}$ Ibid., 259.

${ }^{63}$ Ibid., 266.
} 
destruction. ${ }^{64}$ Yet insofar as discord resists the stasis of anaesthetized perfection, discord continues its role in the production of novelty and in this sense can be said to produce a good. "Progress is founded upon the experience of discordant feelings. The social value of liberty lies in its production of discords." ${ }^{.65}$

In the final chapter of Adventures of Ideas, Whitehead arrives at the concept of Peace, the last item involved in those qualities that constitute civilization. Here Whitehead seeks "for the notion of a Harmony of Harmonies, which shall bind together the other four qualities," and he finally names this Harmony of Harmonies as Peace. ${ }^{66}$ In this context Peace does not equal tranquility or contentedness, engendering feelings of anaesthesia. "It is not a hope for the future, nor is it an interest in present details. It is a broadening of feeling due to the emergence of some deep metaphysical insight, unverbalized and yet momentous in its coordination of values." ${ }^{\mathbf{6 7}}$ Whitehead seems to articulate Peace as that by which the other qualities of Truth, Beauty, Art, and Adventure propel the world toward new endeavors for civilization and toward the "dislocations and confusions marking the advent of new ideals for civilized effort." ${ }^{68}$ In light of the productive nature of discord, this expression of Peace does not disregard negative experience, but "preserves" tragedy. Tragedy for Whitehead is thus an indelible part of the notion of Peace: "The meaning of Peace is most clearly understood by considering it in its relation to the tragic issues which are essential in the nature of things. Peace is the understanding of tragedy, and at the same time its preservation." ${ }^{, 69}$ By this understanding of tragedy, the loss and destruction denoted by tragedy are simply a part of the unfolding of the creative advance. To describe

\footnotetext{
${ }^{64}$ Ibid., 263.

${ }^{65}$ Ibid., 257.

${ }^{66}$ Ibid., 285.

${ }^{67}$ Ibid.

${ }^{68}$ Ibid., 279.

${ }^{69}$ Ibid., 286.
} 
moments of experience without reference to tragedy would be to forego articulation of an essential part of experience. Peace, argues Whitehead, is that aspect that insists upon the preservation of the positive and negative moments inherent in the creative advance:

As soon as high consciousness is reached, the enjoyment of existence is entwined with pain, frustration, loss, tragedy. Amid the passing of so much beauty, so much heroism, so much daring, Peace is then the intuition of permanence. It keeps vivid the sensitiveness to the tragedy; and it sees the tragedy as a living agent persuading the world to aim at fineness beyond the faded level of surrounding fact. Each tragedy is the disclosure of an ideal:-What might have been, and was not: What might be. The tragedy was not in vain. ${ }^{70}$

Whitehead begins with a patient, thoughtful view of deleterious experience of the past that could be analogous to ideas of recollection or remembrance - preserving sensitiveness to tragedy and preserving the memoria of tragic moments. However, at the point at which he includes tragedy in the quality of Peace, as Harmony of Harmonies, for the purpose of aiming at higher ideals beyond the "faded level of surrounding fact" he has endowed detrimental experience with a transcendent purpose beyond itself and has mastered the past in order to lead the world toward greater possibilities for the future. If this is where Whitehead ends with tragedy, this project cannot accept his conclusions concerning preservation of the tragic.

As tempting as the possibility seems, it would be too easy to allow tragedy to be assumed into the harmony of harmonies, such that in the end everything resounds with peace and zest. This is precisely the philosophical position Adorno condemns - the endowment of deleterious events with positive meaning. It smacks of mastery of the past and ends in subsuming the harsh materiality of the world into a neat and tidy concept. However, in Whitehead's discussion of tragedy, he introduces a difference between tragic evil and gross evil that I think proves vital to this project. Tragedy is not always in vain, writes Whitehead — an assertion this project can tentatively accept for some moments of experience, though decidedly not with regard to the

\footnotetext{
${ }^{70}$ Ibid., 286.
} 
debilitating suffering of material reality. "This survival power in motive force, by reason of appeal to reserves of Beauty, marks the difference between the tragic evil and the gross evil., ${ }^{, 71}$ Thus, tragic evil can be synopsized as the loss of what might have been yet was not; whereas gross evil points to simply (or not so simply) unfathomable and immeasurable loss, a true disruption in the system of process such that it cannot be transformed by the motive forces of Discord and Harmony into the quality of Peace. I suggest that the events of the Holocaust involved both tragic evil and gross evil—the former in the lives of individuals, and perhaps at a more general level communities and societies, who lost what could have been with the loss of life; the latter in the infliction of unimaginable suffering on millions of people for no coherent or acceptable reason whatsoever. Gross evil, however, like tragic evil, is not lost to the past. Inasmuch as it continues to be taken into the present as objective datum of the past, and inasmuch as it provides a subjective experience that attains universalization by means of repetition (here we read remembrance and not the repetition that results in the stasis of outworn perfections), gross evil too maintains its own freshness, not for any positive sake, other than perhaps the aim at guarding against its complete, in total repetition as a recurrent series of horrific acts. Gross evil does not aid in the production of Peace, cannot lead to the increase of Beauty in the world by virtue of its contrast, and does not aim at the Zest by which Whitehead sees civilization propelled forward through an adventure of ideas. Yet, neither does it result in the anathematic substitute of Peace, anaesthesia, which deadens feeling and leads inevitably to stasis. Gross evil endures, but for no positive sense. In terms of the Holocaust, one cannot say that the events of Auschwitz positively aided in the processual movement of civilization in any way that couldn't have been accomplished without the events of Auschwitz ever having occurred. Here we poignantly see the difference between aiming at novelty by including certain necessary

\footnotetext{
${ }^{71}$ Ibid., 286.
} 
amounts of discord and needlessly, ruthlessly endowing entirely destructive, irredeemable moments of the past with positive meaning so as to explain the emergence of such experience in the unfolding of the world.

Whitehead concludes Adventures of Ideas and his musings on civilization, tragedy, and harmony as Peace with the following lines:

At the height of the nature of things, there are always the dream of youth and the harvest of tragedy. The Adventure of the Universe starts with the dream and reaps tragic Beauty. This is the secret of the union of Zest with Peace:- That the suffering attains its end in a Harmony of Harmonies. The immediate experience of this Final Fact, with its union of Youth and Tragedy, is the sense of Peace. In this way the World receives its persuasion towards such perfections as are possible for its diverse individual occasions. ${ }^{72}$

The notion of tragedy presented here cannot include the gross evil that Whitehead differentiated from tragic evil several pages prior, and I think that Whitehead realized this. Whitehead himself was no stranger to gross evil, to the type of tragedy that resists positive inclusion into a Harmony of Harmonies. After the loss of his son in the First World War, Whitehead experienced unfathomable, irredeemable loss - an experience that he realized must also be included in the system of general ideas constituting his speculative philosophy. The dialogues with Whitehead recorded by Lucien Price demonstrate the profound sense of loss: "Whitehead once said that the most vivid wordings of grief or attempts or attempts at consolation by those masters of speech, the English poets, to him "only trivialized the actual emotions." included so as to alter the constellation we have called metaphysical reflection, though Whitehead does not include it so as to dissolve the experience into a concept or to explain away the experience by allowing it to increase the production of Beauty in the concrescence of some occasions. In this regard, my reading of Whitehead disavows any endeavor to master the past by viewing tragedy as inclusive of the events of Auschwitz, thus aiding in the sense of Peace.

\footnotetext{
${ }^{72}$ Ibid., 296.

${ }^{73}$ Lucien Price, The Dialogues of Alfred North Whitehead (Jaffrey, NH: David R. Godine, 2001), 7.
} 
While I will allow Whitehead to assert that some tragic aspects inevitable in lived reality can find their end in the Harmony of Harmonies, I unequivocally deny the subsumption of gross evil into the notion of Peace.

As both Adorno and Whitehead insist, metaphysical systems must continually answer to the charge of dogmatism or to the charge of incompatibility with the events of material reality. Whitehead's own system is no exception to this recurring requirement; thus, at points one must read Whitehead against himself in order to avoid the charge that his speculative philosophy has endorsed a means of coming to terms with the past. While I find Whitehead's metaphysics the preferable system for addressing the problems of Vergangenheitsbewältigung and posit that universalization of unique events conceived as remembrance helps to affirm Adorno's new categorical imperative, his system does not (as I have repeated above) resolve all the issues enclosed within the term Vergangenheitsbewältigung. The next chapter will disclose further advances and further complications for discovering a means to affectively remembering the past such that the events of Auschwitz are not repeated. As Whitehead himself remarks: "The speculative methods of metaphysics are dangerous, easily perverted."74 Though perhaps we can, as I will suggest, successfully navigate these treacherous methods so as to derive a means for mastering the present as a presence under God, thereby allowing us to helpfully remember baleful events of the past while critically addressing present conditions.

\footnotetext{
${ }^{74}$ Whitehead, Adventures of Ideas, 295.
} 


\section{Chapter 6: Whitehead and God}

Like Whitehead, I have saved discussion of God until the end; though for both Whitehead and myself, God is anything but an afterthought. In writing Process and Reality, Whitehead realized that his speculative scheme was incomplete without discussion of God. He makes quite clear that God cannot be an exception to the metaphysical system, but must rather be its highest exemplification. ${ }^{1}$ In this sense, Whitehead does not introduce God in the latter pages of Process and Reality in order to save the metaphysical principles from collapse. To the contrary, Whitehead's God has been present all along, from the first chapters of the work, tightly woven into the fabric of this system of general ideas. Even before Process and Reality, Whitehead had unfolded early conceptions of God in Science and the Modern World and Religion in the Making. While his writings in these two earlier works articulate a slightly different God than the one fully explicated in Process and Reality, the presence of discussions about God in both books demonstrates Whitehead's interest in questions of cosmology and the divine. Already when writing Science and the Modern World, Whitehead realized the vital role God must play in his metaphysics, stated in this early metaphysical work as the "Principle of Concretion." ${ }^{2}$ In these lectures (later published in book form), he cites Aristotle's invocation of God in the final sections of his Metaphysics as the sort of cosmic glue holding the system together. Yet, Whitehead does not critique this aspect of Aristotle's conclusion; rather he notes that Aristotle himself was "entirely dispassionate" ${ }^{3}$ with regard to the inclusion of the divine in his metaphysical system: Aristotle did not bring his system to a close with God because of religious motivations or interests, as subsequent European metaphysicians have done. Whitehead sees himself as

\footnotetext{
${ }^{1}$ Whitehead, Process and Reality, 343.

${ }^{2}$ Whitehead, Science and the Modern World, 173.

${ }^{3}$ Ibid.
} 
proceeding along the lines of Aristotle, and in opposition to the impassioned religious interests of metaphysical philosophers like Hegel. Therefore, Whitehead does not disavow the significance of God in his own metaphysical system, but rather he denies God a central or foundational role. Describing those European metaphysical systems in which this is the case, he writes:

[God] has been conceived as the foundation of the metaphysical situation with its ultimate activity. If this conception be adhered to, there can be no alternative except to discern in Him [sic] the origin of all evil as well as of all good. He [sic] is then the supreme author of the play, and to Him [sic] must therefore be ascribed its shortcomings as well as its success. ${ }^{4}$

His own system refutes this location of God as "author of the play," reconceiving God's role as co-creator with the world, or as he puts it at the end of Process and Reality, as the "poet of the world." Moreover, while Whitehead resonates with Aristotle's dispassion regarding religious concerns, his own inclusion of God proves quite different from Aristotle's, since (as stated above) Whitehead's God cannot be an exception to the metaphysical system.

The goal of this chapter will not be to provide a complete description and analysis of the Whiteheadian notion of God, since to do so would require volumes. Instead, this chapter aims at discussing Whitehead's conception of God insofar as it pertains to the problem of coming to terms with the past. In doing so, I will introduce the basic theistic image that emerges from Process and Reality and Adventures of Ideas, reading and, at times, critiquing this image from the viewpoint of a post-Holocaust perspective and particularly in light of Adorno's postAuschwitz categorical imperatives. I will also describe Whitehead's tendentious relationship with theology, which I see as affirming some claims made by Adorno and other post-Holocaust thinkers who attempt to recast a vision of God. The result of my discussion will be an understanding of a God who receives the suffering of the world without erasing or redeeming the

\footnotetext{
${ }^{4}$ Ibid., 179.

${ }^{5}$ Whitehead, Process and Reality, 346.
} 
tragedy by wiping it away, making it null and void. This understanding, as we shall see, aids in the construction of a materialist Christianity arising under a norm of remembrance in some surprising but significant ways.

\section{The Dipolar God}

While Whitehead briefly mentions the dipolar nature of God in earlier chapters of Process and Reality ${ }^{6}$, one must await the end of the book for a complete explanation of these two natures. The final chapter of the book, entitled "God and the World," finally unfolds this detailed elucidation. Here Whitehead succinctly sketches the trajectory of theistic images from the Roman Empire, ancient Hebrew prophets, and Aristotle, writing "three strains of thought emerge which, amid many variations in detail, respectively fashion God in the image of an imperial ruler, God in the image of a personification of moral energy, God in the image of an ultimate philosophical principle."7 Against these three images, Whitehead proposes a vision of God that emphasizes love and "dwells upon the tender elements in the world..." By describing God's agency in this manner, Whitehead subtly refutes other conceptions of God, including most notably the image of God as imperial ruler. If God acts in the world according to principles of love, then one can no longer speak of God as either unmoved mover or as reigning monarch whose agency appears in the world in the form of coercive and dictatorial power. Quite to the contrary, Whitehead refuses any understanding of God that includes such coercion or the possibility that God could act unilaterally in the world according to God's own whims and desires. As I have already mentioned, his metaphysics would not allow this type of divine image, and it remains of utmost importance for Whitehead that God "is not to be treated as an exception

\footnotetext{
${ }^{6}$ Ibid., 31.

${ }^{7}$ Ibid., 342-343.

${ }^{8}$ Ibid., 343.
} 
to all metaphysical principles, invoked to save their collapse"; instead, "[h]e is their chief exemplification." 9 As a consequence, Whitehead develops a divine image based on the persuasive power of love by writing of God as dipolar or composed of two natures, which he terms the consequent nature and the primordial nature. ${ }^{10}$ Moreover, as the chief exemplification of the metaphysical system, Whitehead understands God as an actual entity. If actual entities are the only reasons in the world, then God, as a reason or factor facing future occasions, must too be considered an actual entity. ${ }^{11}$ In this sense, mirroring all occasions that make up the world, God too possesses a mental pole and a physical pole, which can respectively be described as the primordial nature and the consequent nature.

Whitehead, perhaps demonstrating once again the universe's desire to elicit contrast, describes the two natures of God in terms of one another, marking the contrasts between the two as productive for all future becoming. The explanation of the dipolar God here will follow Whitehead's highlighting of difference between the consequent and the primordial natures. To begin with a pertinent characteristic for this unfolding theology of remembrance, God's consequent nature is that part of God which receives the entire content of the past, including the massively disruptive past of the Holocaust. This side of God is "the objectification of the world in God"12 and is thus constituted by the actual occasions of the world. The consequent nature is the "realization of the actual world in the unity of [God's] nature..."13 about which Whitehead writes that it is 'determined, incomplete, consequent, 'everlasting,' fully actual, and

\footnotetext{
${ }^{9}$ Ibid., 343.

${ }^{10}$ In Adventures of Ideas, Whitehead credits Plato with the first enunciation of divine power as persuasive rather than coercive. However, according to Whitehead, Plato failed to coordinate this conception (formulated toward the end of his life) with his metaphysical system. Whitehead, on the other hand, seeks to overcome what he sees as Plato's failure by ensuring that persuasive divine power coheres with the rest of his own metaphysical system. Cf. Adventures of Ideas, 166.

${ }^{11}$ Ibid., 24.

12 Ibid., 345.

${ }^{13}$ Ibid.
} 
conscious." ${ }^{14}$ Conversely, Whitehead describes the primordial or conceptual nature of God as the side of God that is "the unlimited conceptual realization of the absolute wealth of

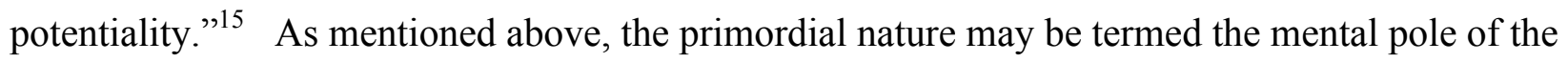
actual entity that is God. As with the consequent nature, Whitehead provides an additional six descriptors for the primordial, each as an opposition or contrast to the six characteristics of the consequent side. As opposed to being “determined, incomplete, consequent, 'everlasting,' fully actual, and conscious," as is the consequent nature, the primordial nature is "free, complete, primordial, eternal, actually deficient, and unconscious."16

Explicating each of these six pairs of descriptors in turn reveals more precisely how Whitehead understands the dipolar natures. With regard to the first and third pairs of terms, God receives into God's consequent nature a positive prehension of every actual occasion, and as a result this side of God's nature is both determined by the actual world and consequent, or follows from the actual world. By contrast, the primordial nature, as free, is not dependent upon the actual world - the actual occasions that concresce, reach satisfaction, and perish do not alter the realm of conceptual possibilities inherent in God. Likewise, the primordial nature is primordial (as should be obvious from its name) insofar as God co-existed with the world from the beginning of temporality. Whitehead writes that God "is not before all creation, but with all creation," denoting God's co-eternality with the world and with the principle of creativity. ${ }^{17}$ Regarding the second contrasted terms, whereas the consequent nature changes over time as it continues to receive the content of the actual world, and thus remains incomplete, since the processual unfolding of the world continues without end, the primordial nature must be termed

\footnotetext{
${ }^{14}$ Ibid.

${ }^{15}$ Ibid., 343.

${ }^{16}$ Ibid., 345 .

${ }^{17}$ Ibid., 343.
} 
complete, as it provides the receptacle in which the eternal objects find their "place". By determining the eternal objects to be an infinite multiplicity to which nothing more can be added because it is already infinite, the completeness of the primordial nature becomes clearer. Moreover, contrasted with the consequent nature, which remains incomplete with regards to history, the primordial nature must be complete insofar as it does not grow as a result of the unfolding of history, but rather provides the locus of the infinite multiplicity of potentiality for history's unfolding. Turning to the fourth terms, the consequent nature can be termed fully actual because, as opposed to the primordial nature, it contains the entirety of the actual world, once actual entities in that world have perished. In this sense, the consequent nature is devoid of possibility, but contains all that has become actual in the world. The primordial nature, however, must be considered actually deficient, since it remains the receptacle of possibilities. The eternal objects present in the primordial nature, as mentioned in chapter four, cannot be said to be actual until they are positiviely prehended by a concrescing actual entity; therefore, this realm of pure potentiality is devoid of actuality. Fourth, consciousness, for Whitehead, is derivative of higher phases of concrescence, and thus not all actual occasions may be said to be conscious. God, however, as an actual entity attains consciousness in the physical pole (the consequent nature) insofar as God values prehensions of the physical world combined with the potentiality emerging from the primordial nature, thereby reaching a higher phase of concrescence. Conversely, Whitehead labels the primordial nature unconscious in respect to the consequent nature since it mediates all possible becomings within all possible worlds but, itself, remains only potential or non-actual. Thus, the terms conscious and unconscious evidence an element of relationality, since they are terms only full realized when considered relative to the other. Finally, Whitehead terms God's consequent nature everlasting because it is "the fluent world become 'everlasting' 
by its objective immortality in God." ${ }^{\prime 18}$ One can say that the entire content of the past is relevant to this side of God's nature. Nothing is omitted or lost to the past; there are no negative prehensions for God, but rather all actual occasions are positively prehended and attain objective immortality — the position of becoming an object for all future subjects—in the consequent nature. The realm of possibilities constituting the primordial nature, on the other hand, remains eternal and non-temporal (as opposed to the decidedly temporal character of the consequent nature), insofar as it remains unaffected by events within the temporal world.

By delineating God's consequent nature as the repository of all past moments of experience, we can argue that Whitehead's philosophy ensures a means by which harmful events of the past are not glossed over or lost, but remain as content received into God's nature and constitutive of an on-going evolution of God's nature. God is constantly changed and refigured by the actual world through God's positive prehensions of each occasion, each drop of experience. If the consequent nature can truly be termed consequent, determined and 'everlasting', then it must also change and refigure itself by prehending the rupturing experiences of the Holocaust and the on going suffering emanating therefrom. Clearly, this is a direct refutation of Aristotle's God as unmoved mover. Whereas Aristotle introduced God as the necessary finishing piece, the object of thought and desire, which itself remains unmoved, Whitehead immerses God into the metaphysical system in a way that results in God's intrinsic and immanent relatedness to all occasions in the actual world. Instead of being the unmoved mover, by virtue of the consequent nature, Whitehead's God could be termed the most moved mover. $^{19}$

\footnotetext{
${ }^{18}$ Ibid., 347.

${ }^{19} \mathrm{I}$ borrow this phrase from the title of Clark H. Pinnock's book on open and relational theological conceptions of the divine, Most Moved Mover: A Theology of God's Openness (Grand Rapids, MI: Baker Academic, 2001).
} 
From the primordial nature comes the pure potentiality given to each becoming occasion. This side of the nature of God is "the unconditioned actuality of conceptual feeling at the base of things; so that, by reason of this primordial actuality, there is an order in the relevance of eternal objects to the process of creation." 20 By ordering or patterning the eternal objects as relevant to each moment of concrescence, God becomes “the lure for feeling...the initial 'object of desire' establishing the initial phase of each subjective aim." ${ }^{21}$ God orders the eternal objects, the wealth of potentialities conceptually available to each occasion, before providing occasions in the world with a lure toward a specific subjective aim, the self-selected purpose of each actual occasion. This lure or initial aim is then prehended by concrescing occasions in the mental pole of concrescence, as described in chapter four. Inasmuch as the wealth of potentiality in God's primordial nature grounds the future by providing the possibilities for each future moment, then an occasion's “future must be viewed as its beginning, since it becomes possible 'in the future' before it realizes itself in the present. ${ }^{, 22}$ As I described in greater detail in the previous chapter, occasions arise out of the tension between the past (re-enaction) and the future (anticipation). As Roland Faber writes, God's primordial nature is "the locus of the infinite potential of unrealized possibilities," and may, therefore, be termed the "absolute future." 23 Thus, the primordial nature as absolute future discloses possibility to the world through the initial aim in each present moment of becoming. Here we again see God's significant role, as Whitehead conceives it, in the relationship between past and future within the becoming of each occasion. God as absolute future yields as yet unrealized possibility to each moment of becoming, enabling that moment to take on a different form than the previous moment. In this sense, process theologians have

\footnotetext{
${ }^{20}$ Whitehead, Process and Reality, 344.

21 Ibid.

${ }^{22}$ Faber, God as Poet of the World, 84.

${ }^{23}$ Faber, God as Poet of the World, 84.
} 
written of God as transforming the world through the initial aim, offering different, transformed possibilities from the wealth of potentiality in God's primordial nature.

In addition to the notion of God as absolute future, it must be noted, as Marjorie Suchocki describes in her appendix to God, Christ, Church, that the mental and physical poles in God are reversed with respect to actual occasions in the world. Whitehead himself alludes to this reversal with the following quotation:

An actual entity in the temporal world is to be conceived as originated by physical experience with its process of completion motivated by consequent, conceptual experience, initially derived from God. God is to be conceived as originated by conceptual experience with his process of completion motivated by consequent, physical experience, initially derived from the temporal world. ${ }^{24}$

Rather than beginning in the physical pole and proceeding to the mental pole, God as actual entity begins in the mental pole and proceeds to the physical. Suchocki argues for this reversal in order to solve some specific problems related to the way in which actual entities receive (prehend) possibilities. Actual entities "eliminate possibilities" as they concresce in order to move toward the unity that constitutes the actual entity at the point of satisfaction. She questions how God, as an actual entity, can ground possibilities if the movement from the multiplicity of the past in the physical pole to the subjective aim realized in the mental pole requires the exclusion of some possibilities. Suchocki summarizes the problem with the following four statements: "1. Possibilities exert power in affecting the actions of actualities. 2. But all power must be located in actuality. 3. If possibilities exert power, they must do so through the agency of an actuality that is their origin. 4 . But no finite actual entity thus far described can perform this function." 25 Conceiving God as an actual entity (as actuality) moves toward providing a metaphysically consistent and coherent answer to these problems; however, even by naming God

\footnotetext{
${ }^{24}$ Whitehead, Process and Reality, 345

${ }^{25}$ Marjorie Suchocki, God, Christ, Church: A Practical Guide to Process Theology (New York: Crossroad Publishing Company, 1989), 247-248.
} 
as a single actual entity, one must still solve the problem of how possibilities are not eliminated, but maintained/contained, in God's mental pole or primordial nature. Reversing the order of the mental and physical poles means that the possibilities in the mental pole are not limited by the actual world prehended in the physical pole (consequent nature). In the temporal world, actual entities would negatively prehend some possibilities in the mental pole that would prove incompatible with the relevant past prehended in the physical pole. God, on the other hand, can include no such limitation of possibilities in the mental pole, and this reversal ensures that God's primordial nature is not limited by the actual content of the consequent nature. Thus, God as actual entity becomes a mirror image of all other actual entities, which results in the statement that God "begins" in the mental pole, or primordial nature. As a result, "God's primordial beginning is a 'satisfaction' in which all possibilities are everlastingly unified in terms of value. ${ }^{26}$ This original satisfaction then issues into a subjective aim, which in turn moves toward the consequent nature (God's physical pole) in order to relate the possibilities of the primordial nature to the actual world prehended into God's consequent nature. As stated above, unlike all other actual entities, God does not have any reason to negatively prehend any antecedent occasion, since "God's physical pole is unlimited by any need for selectivity, given the already achieved unity of all possibilities in the primordial vision." ${ }^{27}$ Suchocki nicely summarizes the process of divine concrescence in her appendix to God, Christ, Church:

God's eternal satisfaction generates a subjective aim that directs the concrescence of God. In keeping with the dynamics of reversal, the aim moves toward the world and then through the world in prehension to direct the concrescence of God. In the everlasting process, the consequent nature is integrated with the primordial nature in unity.

When Suchocki writes that the divine aim moves "toward the world and then through the world," she not only points to God's prehension of all occasions in the world, but also to God's initial

\footnotetext{
${ }^{26}$ Ibid., 249.

${ }^{27}$ Ibid., 250-251.
} 
aim offered to each actual entity as a part of that entity's own mental phase of concrescence. In this manor, God acts in the world not through coercion, as Whitehead himself wished to deny, but by offering a lure toward better possibilities in the future (and from the future, as pure possibility). For this reason, Suchocki refers to God as "the supremely related one." 28 God not only relates to the world by receiving the content of the world into God's own nature, but also by providing a lure or initial aim for each occasion in the actual world.

The reversal of the physical and mental poles within God has a bearing on the way in which deleterious past occasions are prehended and maintained within God's consequent nature in two ways: first, in a manner that accords to the traditional (Christian) theological reading of Whitehead, and second, in a way that highlights how we might read Whitehead against himself, so to speak, in order to heed the warnings and prohibitions of Adorno and Voegelin outlined in the first section of this project. I'll outline the first implication, from a traditional reading of Whitehead, briefly here and will save the second implication for the next section, which discusses the inclusion of evil and suffering within God in greater detail. According to the first implication, if the primordial nature provides a subjective aim in terms of which the content of the consequent nature can be evaluated, then the consequent nature (led by the subjective aim emerging from the primordial nature) weaves the content of the past into a harmonious, completed whole. Whitehead describes this process, specifically noting the disruptive and sorrowful actualities: "The wisdom of the subjective aim prehends every actuality for what it can be in such a perfected system-its sufferings, its sorrows, its failures, its triumphs, its immediacies of joy—woven by rightness of feeling into the harmony of the universal feeling... ${ }^{29}$ His statement repeats the notion that the subjective aim enables the consequent

\footnotetext{
${ }^{28}$ Ibid., 251.

${ }^{29}$ Whitehead, Process and Reality, 346.
} 
nature to examine past actualities in terms of what they might have been, "What might have been, and was not: What can be. ${ }^{\prime 30}$ Two other significant passages from this section of the final chapter of Process and Reality warrant quotation, since each elucidates how Whiteheadians traditionally read the chapter as denoting a final salvation of what was into the harmony of God's consequent nature, in which God realizes what might have been and what still could be. First, Whitehead writes: "The revolts of destructive evil, purely self-regarding, are dismissed into their triviality of merely individual facts; and yet the good they did achieve in individual joy, in individual sorrow, in the introduction of needed contrast, is yet saved by its relation to the completed whole." ${ }^{31}$ Like the latter pages of Adventures of Ideas, traditional readings of this passage highlight the fact that the injurious past, though in itself disruptive, produces certain contrasts necessary in order to propel subsequent actualities toward novelty. Moreover, this quotation demonstrates the way in which Whitehead aims at preserving the tragedy of actuality as a part of the "completed whole." Second, Whitehead describes the consequent nature as God's "judgment on the world. He saves the world as it passes into the immediacy of his own life. It is the judgment of a tenderness which loses nothing that can be saved. It is also the judgment of a wisdom which uses what in the temporal world is mere wreckage." ${ }^{32}$ Here he demonstrates the means by which every moment of the past is "saved" within God's consequent nature, according to the subjective aim produced by the primordial nature. The last portion of this quotation leads one to think that harmful moments of the past might find some positive use within God's wisdom, by shaping future subjective aims in response to such deleterious moments. However, this project maintains that these passages must be read in a different manner, since, as was determined by our discussion in the last chapter, any understanding of the

\footnotetext{
${ }^{30}$ Whitehead, Adventures of Ideas, 286.

${ }_{32}^{31}$ Whitehead, Process and Reality, 346.

${ }^{32}$ Ibid.
} 
wreckage of actuality as ultimately useful or ultimately bound up in the harmony of a completed whole flies in the face of the atrocities of the Holocaust.

\section{Problematizing Whitehead's God}

As mentioned above, we must not understand the dipolar nature of God as finally settling the problem of Vergangenheitsbewältigung. Indeed God's consequent nature receives the Holocaust in all of its deleterious uniqueness, and indeed God's primordial nature provides the realization of potentiality out of which we might come to terms with the present. However, the disruptive nature of such an event prohibits us from finally allowing Whitehead's vision of God to too easily turn this past event into "redeemed" past. The Holocaust as past event remains within God and within the prehension of subsequent occasions as objective data that is a "mass of pain and misery, a bagatelle of transient experience."33 Yet in no way can this project accept the traditional readings of those lengthy passages of Whitehead cited above in which devastating past leads to productive future. As I alluded at the end of the previous section, traditional (and dominant) readings of Whitehead's final chapter in Process and Reality understand God as saving and transforming all that has occurred in the actual world within God's own actuality, as to say, within God's consequent nature. However, I suggest an alternative reading that heeds the warnings and prohibitions of Adorno and Voegelin with regard to the problem of coming to terms with the past. It would prove antithetical, and even anathema, to this project if we allowed Whitehead's God, which appears to be a covertly (if not overtly) Christian conception of God, to solve the problem of Vergangenheitsbewältigung. To do so would result in a mastery of the past within the nature of God that appropriates the suffering of damaged life into that which is the ground of actuality. Instead of adopting this stance, the following section will unfold my

\footnotetext{
${ }^{33}$ Whitehead, Science and the Modern World, 192.
} 
alternative reading of Whitehead in which the past may be saved, in the sense that the past remains interminably without being redeemed or without proving somehow useful for the becoming of subsequent occasions.

In Faber's section on "Evil, Tragic Beauty, and Theodicy” in God as Poet of the World, he takes up the question of theodicy in Whitehead's thought, noting that Whitehead himself was much less concerned with theodicy than those process thinkers who followed him. For Whitehead the presence of evil and suffering in the world does not undercut God's metaphysical reality or the role God plays in receiving the actual world and offering an initial aim back to that world. Instead, he views evil as a possibility inherent in the structure of the universe. ${ }^{34}$ Returning to the above passage from Science and the Modern World, human experience may well be a mass of pain and misery. Yet insofar as Whitehead himself demonstrates no interest in "solving" the problem of theodicy, Faber writes that "Whitehead neither dissolves evil into God-as a moment in God's becoming — nor views it as an evolutive necessity."35 Thus, Faber offers a means to argue that deleterious occasions serve no redemptive purpose or find no ultimate "mastery" within divinity, nor are such occasions necessary in order to provide God with greater contrasts leading to new possibilities for actuality. The evil that issues into horrific moments of suffering just is; moreover, it can be understood as maintained within God's consequent nature, and therefore felt by God, without being endowed with positive meaning or redemptive purposefulness.

Faber goes on to characterize the two dominant positions in process theology regarding the presence and possibility of evil, the first of which can undoubtedly be termed a process theodicy. David Griffin's treatment of evil alongside a Whiteheadian conception of God argues

\footnotetext{
${ }^{34}$ Faber, God as Poet of the World, 290.

35 Ibid.
} 
that evil occurs in the world due to God's non-coercive nature. Since God cannot act unilaterally in the world, but must persuade the world toward those possibilities which God intends for the world through God's initial aim, God cannot somehow step into the world to stop the course of evil. Faber represents Griffins argument as professing God to be both good and omniscient, but not omnipotent, "not as an almighty, all-determinative God and thus also not as a God with complete responsibility." ${ }^{, 36}$ Instead, Griffin adopts a vision of God along the lines of Whitehead's dipolar God in the last chapter of Process and Reality who may be termed "the fellow-sufferer who understands." 37 By prehending the actual world in God's consequent nature, God feels the world in all of its triumphs, joys, and suffering; and it is for this reason that Whitehead describes God as co-sufferer with the world when God feels harmful occasions. While I don't find Griffin's approach to the question of theodicy particularly compelling as a method for understanding deleterious suffering, I do value Whitehead's depiction of God as the fellow sufferer, since the fact of God's co-suffering with the world need not mean that such suffering is redemptive. Like Faber, I do not wish to critique Griffin's response to the question of theodicy on the position of God's suffering. Instead, Faber evaluates Griffin's response on the very metaphysical grounds upon which Griffin's argument is based: “A God who cannot want this world process to be otherwise, since it contributes to God's own inner being, is still—even if God cannot do otherwise - a God who lives from the evil and suffering of the world." ${ }^{\text {,3 }}$ Hence, Faber does not reject the metaphysical claims Griffin makes, but he also does not accept them as a solution to the problem of evil.

In contrast to Griffin's process theodicy, Faber next explores a position that I suggest resists application of the term theodicy altogether. He describes Bernard Loomer's treatment of

\footnotetext{
${ }^{36}$ Ibid., 291.

${ }^{37}$ Whitehead, Process and Reality, 351.

${ }^{38}$ Faber, God as Poet of the World, 292.
} 
evil and suffering within the Whiteheadian God in Loomer's work "The Size of God." Faber introduces Loomer's discussion of evil by indicating that it is "focused neither on justifying God in the face of suffering, nor on the question of the origin and admittance of evil in the face of a good God, nor on sublating the world's 'ambiguity' in an eschatological consummation (all these 'solutions' can be viewed as having failed). ${ }^{39}$ Instead, Loomer settles on an ambiguous conception of God as the best possible understanding of God in light of the reality of evil in the world. Loomer refuses to allow evil to move toward a redeemed perfection, but rather conceives of God as the concrete actuality of the whole world, which means that as "concreteness" God is "living indecision or irresolution, that is, ambiguity..."40 The size of God alludes to the fact that God includes the entirety of the actual world in God's own on-going concrescence, and the inclusion of tragedy and suffering alongside joyful occasions leads Loomer to the statement that God must be understood as ambiguous. By reading Whitehead's depiction of God in this way, he avoids subscribing a finality or harmonious perfection to God's consequent nature (which I suggest, alongside Loomer, that it was never intended to be). This position resists assigning any positive meaning, or any meaning whatsoever, to evil and suffering emanating from the world. It does not seek to explain how or why evil may be present in the world, contra Griffin; and for this reason I deny that Loomer's position is in fact a theodicy at all. ${ }^{41}$ As Faber surmises, Loomer's reading of Whitehead means, "the concrete size of God's everlasting concrescence corresponds to infinite ambiguity, never dissolving into the past, into perfection, into unequivocalness, structure, and stasis. ${ }^{, 2}$ Thus, the deleterious past events of the Holocaust are maintained within God's consequent nature without allowing that God seeks some utilitarian purpose for these

\footnotetext{
${ }^{39}$ Ibid., 292.

${ }^{40}$ Ibid., 293.

${ }^{41}$ In subsequent chapters I will describe more precisely why this project rejects the notion of theodicy altogether, citing the work of Emmanuel Levinas in his essay "Useless Suffering."

${ }^{42}$ Faber, God as Poet of the World, 293.
} 
horrific moments. The occasions, instead, may be remembered without being redeemed in the traditional sense of transformation for some future purpose. Moreover, allowing God to remain ambiguous heeds the necessary warnings against squeezing some sort of meaning out of the events of the Holocaust or sublating the movement of history into a transcendent synthesis or unity. Loomer writes that an unambiguous God "has at best the status of an abstraction," since God would be abstracted from actual reality, which is itself ambiguous, a bagatelle of experience. Consequently, the idea of God as ambiguous "is of greater stature than an unambiguous deity.",43

The harmful past of the Holocaust is allowed to remain unsettled, rather than requiring a move toward perfection, sublation, or abstraction into an eschatological completion or redemption. In this sense, I indeed argue against the normative Christian reading of Whitehead, particularly that which emerges from the latter pages of Process and Reality cited above. While Whitehead writes that God "saves the world as it passes into the immediacy of [God's] own life," I do not read this saving as a positive transformation of the past, but rather as the measure that no experience from the actual world be lost.

Additionally, to return to the second of the two implications stemming from the reversal of the mental and physical poles in God's concrescence, inasmuch as God moves conversely to the world from the one into the many, the tragic aspects of the world cannot be said to achieve any sort of final unity in God. In chapter four I cited Whitehead's statement that in the actual world, "the many become one and are increased by one," $" 4$ to denote the movement of the multiplicity of the data of the past and the possibility of the future from a many to a one within the concrescence of each actual occasion. Whitehead delineates a number of antitheses in God's dipolar nature that cannot, and should not, be reconciled, but must remain a pair of opposites

\footnotetext{
${ }^{43}$ Bernard Loomer, "The Size of God," in The Size of God: The Theology of Bernard Loomer in Context, ed. William Dean and Larry E. Axel (Macon, GA: Mercer University Press, 1987), 43.

${ }^{44}$ Whitehead, Process and Reality, 21.
} 
reflective of the dipolar nature itself. Here he notes that terms such as fluency and permanence, immanence, transcendence, and actuality are relative in both God and the world with respect to either the primordial or consequent natures and with respect to an actual occasion's becoming or perishing. He writes: "It is as true to say that God is one and the World many, as that the World is one and God many." ${ }^{45}$ To unpack this statement a bit, Whitehead means that in God's primordial nature, God is one, whereas in God's consequent nature God is many; and in terms of the disjunctive multiplicity of the past, the world is many, whereas in terms of the point of satisfaction for a particular actual occasion, the world is one. The world moves from this disjunctive multiplicity into the unity of a given actual occasion (albeit a momentary unity). Yet, by reason of the reversal of the mental and physical poles, following Suchocki's argument, the movement from many to one is also reversed in the actual entity that is God: "Thus God is to be conceived as one and as many in the converse sense in which the World is to be conceived as many and as one." ${ }^{46}$ If God proceeds from the mental pole or the primordial nature, which provides a subjective aim for God's own becoming, to the physical pole as the positive prehension of the disjunctive multiplicity of the actual world, then the movement within God must be from the one-ness of the subjective aim conceived in the primordial nature to the manyness of the consequent nature. And this is where I suggest that we must read Whitehead against himself.

If God moves from one-ness to many-ness, or from unity to multiplicity, then we can propose that tragedy is not overcome, mastered, or sublated in God's consequent nature. There isn't a final unity, but rather a movement toward multiplicity and, following Loomer, ambiguity. With this in mind, we can re-read the quotations from Process and Reality cited above against

\footnotetext{
${ }^{45}$ Ibid., 348.

${ }^{46}$ Whitehead, Process and Reality, 349.
} 
the grain and in tandem with the notion of this movement toward multiplicity and ambiguity. To remind us of the traditional readings against which I am arguing, let me repeat Whitehead's statements and respond to each. The first reads: "The wisdom of the subjective aim prehends every actuality for what it can be in such a perfected system —its sufferings, its sorrows, its failures, its triumphs, its immediacies of joy—woven by rightness of feeling into the harmony of the universal feeling..."47 While Whitehead employs the phrase "perfected system," we know from previous chapters that there is no such perfected system as a finality or a finished system. The system remains always in process, though it does seek "such perfections as are possible for its diverse individual occasions.. ${ }^{48}$ Perfection, for Whitehead, can only be viewed in terms of temporality and can only be momentary, a satisfaction achieved by the becoming of each individual occasion. "Life," writes Faber, referring to the present and future of all becomings (including God's own becoming), "by contrast is thus always found only in the mode of the 'imperfect,' being necessarily 'abmivalent,' unconcluded or open ended,' and in this sense the only perfected system lies in the satisfaction of past occasions insofar as each occasion reached its own "perfection," as to say, it's own momentary finality in which it becomes an objective datum of the past. While the subjective aim, coming from God's primordial nature, may have realized what each moment could be, the consequent nature realizes it for what is actually was. As a result, while one could indeed conclude that a harmony is present in the primordial nature in which God weaves together each intended outcome for future occasions, the consequent nature cannot achieve such a harmony by virtue of its sheer many-ness as the memory of the disjunctive actual world.

\footnotetext{
${ }^{47}$ Ibid., 346.

${ }^{48}$ Whitehead, Adventures of Ideas, 296.
} 
The second quotation of Whitehead's that I read against the dominant interpretation is as follows: "The revolts of destructive evil, purely self-regarding, are dismissed into their triviality of merely individual facts; and yet the good they did achieve in individual joy, in individual sorrow, in the introduction of needed contrast, is yet saved by its relation to the completed whole."49 First, a note on Whitehead's description of evil as "purely self-regarding." The evil described in this project (in Whitehead's terms: gross evil, as opposed to tragic evil, as differentiated in the previous chapter) may be termed self-regarding for two reasons. First, actual occasions characterized as evil are those occasions which concresce contrary to the initial aim provided by God's primordial nature, and thus they come together with little regard as to the harmony among occasions to which they are intrinsically related. Second, designation of evil as self-regarding can be inserted into a discussion of the positive role of discord as (partially) aiding the adventure of the universe. Inasmuch as evil is self-regarding, it absolutely cannot contribute to the discord that propels adventure: "Evil...consists not in the 'discordance' or the 'imperfect' as such, but in the causally (in the past) or spontaneously (within self-creativity) grounded inability to deal creatively with discordance." ${ }^{50}$ In other words, evil disrupts both harmony and discord by dislodging any movement toward a creative advance. Contrary to the creative advance, in fact, evil may be analogous to the anesthesia Whitehead describes in Adventures of Ideas, the destruction of a "quality of 'life and motion.",51 Faber makes exactly this point, further arguing against the notion that evil can be integrated into a harmony in order to increase intensity, which leads to greater adventure (the role of discord). He writes: "it is the failure of integration that generates evil as a form of anaesthesia, aesthetic breakdown."52 Evil resists

\footnotetext{
${ }^{49}$ Whitehead, Process and Reality, 346.

${ }^{50}$ Faber, God as Poet of the World, 297.

${ }^{51}$ Whitehead, Adventures of Ideas, 285.

${ }^{52}$ Faber, God as Poet of the World, 297.
} 
integration by virtue of its self-regarding nature, thereby leading to anaesthetized stasis, the opposite of intensity and adventure. Since evil is thus "purely self-regarding," evil cannot lead to greater constrasts or intensities within God's own concrescence: "God does not 'integrate' evil for the sake of enhancing God's own intensity, since evil fundamentally always involves a loss of intensity—indeed, the collapse of intensive harmony." ${ }^{, 53}$ Moreover, God requires no increase of intensity from the actual world, since God's primordial nature itself is "absolute intensity" prior to any prehension of actuality in the consequent nature. The primordial nature exists as "the measure and standard of all intensity," and thus needs no increase of intensity from actual occasions within the world. ${ }^{54}$

Yet, further problems arise regarding Whitehead's statement. When he writes of the revolts of destructive evil as being "dismissed into the triviality of their individual facts..." are we to accept that evil moments are trivial for Whitehead because they represent only some small set of facts among many? Doesn't the fact of any destructive or gross evil require acknowledgment and remembrance, rather than permission to be dismissed into triviality? In fact, perhaps allowing deleterious or evil events to be regarded as trivial in comparison to the wealth of positive events results in a certain mastery of the past, enabling the harmful past to fade from consciousness into the forgotten and settled past. I maintain that this sort of mastery is precisely what Whitehead is ultimately against, since the fading of deleterious events may itself be a sort of evil, allowing anesthesia to creep into the system of process. Maintaining the freshness of evil and its effects, while incapable of (and prohibited from) aiding the positive movement toward adventure, may ensure that the harmful past does not fade into mere triviality, but remains as a vivid reminder of what must be guarded against. In terms of Whitehead's

\footnotetext{
${ }^{53}$ Ibid.

${ }^{54}$ Ibid.
} 
notion of the dipolar God, we can clearly see a place for the remembrance of such evil, or remembrance of the atrocities of the Holocaust, within God's consequent nature, now understood via Loomer and Faber as encompassing of the entirety of the actual world and, thus, as ambiguous, since no element of the past (good or bad) warrants any less inclusion than another.

As can be seen from the two passages to which I refer from Process and Reality, and from passages cited from Adventures of Ideas in the previous chapter, Whitehead's relationship to tragedy and evil is itself complicated and ambiguous. As I have discussed, Whitehead does regard some tragic events as necessary for producing the discord essential for the movement toward adventure and novelty. Nevertheless, he denies this positive role to the gross evil or destructive evil characterizing events such as the Holocaust. Introducing the dipolar God in the last chapter of Process and Reality does not dissolve his ambiguity with regard to tragedy and evil, but only further complicates it. The events of the Holocaust constitute a past that cannot be mastered, effaced, or allowed to fade into triviality by virtue of their character as ruptures of history, moments that call into question the very progression of history itself. The argument presented here resists any vision of God that proclaims to have solved the problem of Vergangenheitsbewältigung by resolving the tensions of horrific moments into a harmony of harmonies. To the contrary, these events receive prehension into God's consequent nature, for Whitehead, resulting in God's remembrance of the events of the Holocaust and in a notion of God as ambiguous. Whitehead himself never wished to articulate a fully developed theology, or really a theology of any sort, and thus cannot be said to have unfolded a theodicy aimed at explaining (or explaining away) evil. 


\section{Whitehead's Relationship to Theology}

Whitehead's philosophy resists being classified as theology (or theodicy) primarily because of the fact that Whitehead exhibits a negative view of traditional theology in his own work. While numerous theologians have taken up Whitehead's metaphysics and used it to develop robust Christian (and non-Christian) theologies ${ }^{55}$, one can argue that Whitehead himself never explicitly intended this development. One must also note that he certainly never wrote or said anything to forbid or inhibit such a development. Nevertheless, Whitehead's own relationship to theology can be described as vexed at best, as this section will demonstrate. In what follows I will evaluate and reflect on the various places in Whitehead's work where he mentions theology or theologians, beginning with Science and the Modern World, the first philosophical text of Whitehead's in which he mentions God, turning then to Religion in the Making, Process and Reality, and finally Adventures of Ideas. The purpose of this section will be to serve as a transition into the third and final part of this dissertation, which unfolds a Christian theology of remembrance drawing from strands of Whitehead's, Adorno's, and Voegelin's thought. By discussing and elucidating Whitehead's negative evaluation of theology, I hope to avoid the pitfalls into which he sees traditional theologians as falling. More importantly perhaps, this discussion attempts to demonstrate that Whitehead's work cannot be viewed as a Christian mastery of harmful experiences in the life of Judaism - a move that would be entirely anathema to this project as a whole.

In Science and the Modern World, Whitehead takes up what will become his longstanding argument against theology (or at least against traditional theology), which is that

\footnotetext{
${ }^{55}$ Most notably, Charles Hartshorne and John B. Cobb, Jr. have become known as the founders of process theology, a type of (predominantly) Christian theology based on a Whiteheadian metaphysics. Other Christian theologies display an influence of Whitehead's thought: namely, the theological work of Sallie McFague, Philip Clayton's panentheist philosophical theology, as well as Roland Faber and Catherine Keller's reading of Whitehead alongside Gilles Deleuze and other poststructualst and deconstructionist thinkers.
} 
theology adopts and adheres to a set of dogmas without sufficient regard to the necessary and actual flux of the universe, or evolution of ideas. He describes the advance of science as derived from various contradictions in the evolution of thought and scientific theory and remarks that Christian theology has failed to do the same. "In formal logic," he writes, "a contradiction is the signal of a defeat: but in the evolution of real knowledge it marks the first step in progress towards a victory." Yet his words against Christian thought draw attention to the opposite movement, away from progress and transformation and toward a dogmatic finality: "The failure of Christians to act up to this precept ${ }^{56}$, of the highest authority, is one of the curiosities of religious history." 57 With this in mind, he reports a "gradual decay of religious influence in European civilization," citing religion's tendency to perpetuate ideas received from the previous generation, rather than embarking on the task of altering doctrines so as to allow the doctrines to evolve alongside the general movement of history, the flux of the universe. It is the failure to transform embedded or inherited religious and theological assumptions into deliberative statements in light of ongoing experience. Whitehead's argument against traditional theology as it appears in Science and the Modern World can be summarized with the following lines:

"Religion will not regain its old power until it can face change in the same spirit as does science. Its principles may be eternal, but the expression of those principles requires continual development." ${ }^{, 58}$ When religion fails to change in the face of new experiences, theologians become like "the garrison of a fort surrounded by hostile forces,"

\footnotetext{
${ }^{56}$ Whitehead summarizes the precept as follows: "Let both grow together until the harvest." This is a quote from Matthew 13:30, Jesus' parable of the weeds that are allowed to grow up among the wheat until the time of harvest. Whitehead makes use of this line to demonstrate how two contrary ideas can be simultaneously maintained until such a time that one can be demonstrated as false and the other correct.

${ }^{57}$ Whitehead, Science and the Modern World, 187.

${ }^{58}$ Ibid., 189.

${ }^{59}$ Ibid.
} 
reform theological doctrines in light of the continual flux of religious and other experience, marks the death of religion.

His comments regarding theology in Religion in the Making echo the same concerns with dogmatic finality from Science and the Modern World. Whitehead reminds us that charges of idolatry have been "bandied to and fro among rival theologians" ${ }^{\prime \prime 0}$ throughout the centuries of Christian thought, leveled whenever one theologian cites another has apologetically defending dogma that the other sees as final, settled, and static. Whitehead, however, extends the charge to all Christian theologians equally: "Probably, if taken in its widest sense, [the charge of idolatry] rests with equal truth on all the main churches, Protestant and Catholic. Idolatry is the necessary product of static dogmas." ${ }^{\circ 1}$ Additionally, Whitehead critiques Christian theology for a omitting direct intuition of the divine, seeking only knowledge of the divine through inference. Inasmuch as he desires theologians to take seriously a metaphysical understanding of the world with its basis in actuality (and descriptive of all moments of experience), he regards the omission of religious experience from mainstream theology as one of its chief errors. ${ }^{62}$

Theology or theologians receive mention only three times in the 351 pages of Whitehead's magnum opus, Process and Reality (only two of which actually appear as part of a discussion of theology), and each is either an ambiguous or negative mention of the term(s). The first appears in the second part of the text and follows a discussion of the flux of the world or evolution of history as driven by internally determined occasions such that the flux or evolution could have occurred differently. For this reason, the movement of history or the flux of the universe does not exhibit any sense of 'perfection.' To the contrary, Whitehead labels religion as focused upon the 'imperfection of the world' insofar as religion attempts to provide a means for

\footnotetext{
${ }^{60}$ Whitehead, Religion in the Making, 147.

${ }^{61}$ Ibid., 147.

${ }^{62}$ Ibid., 62.
} 
escaping the imperfection of the actual world in favor of some transcendent world beyond. Turning to Leibniz's apparent distinction of the actual world as inherently imperfect, he writes, "The Leibnizian theory of the 'best of possible worlds' is an audacious fudge produced in order to save the face of a Creator constructed by contemporary, and antecedent, theologians. ${ }^{" 63}$ His statement here implies that theologians have utilized a perception of this world as the best world possible in order to maintain notions of omnipotence and omniscience for God as creator of this world alongside a view of the world as imperfect, thus making necessary some ultimate and final escape (a notion we shall further critique in the final chapter). This mention of theology demonstrates the way in which Whitehead sees theologians as performing philosophical summersaults in order to maintain a pre-determined conception of the divine and of the divineworld relationship. Against such positions, Whitehead writes emphatically against conceiving God as an exception to the metaphysical rules and against philosophical maneuvers intended to save God from certain conclusions. Moreover, his own vision of God does not require that theologians "save" God's omnipotence, given the fact that the world, creativity, and God (at minimum) are co-eternal.

The third mention of theology in Process and Reality, and the other indication of his position regarding theology, comes in the beginning of the final chapter, the chapter in which he fully explicates his notion of the dipolar God. Here Whitehead writes:

The notion of God as the 'unmoved mover' is derived from Aristotle, at least so far as Western thought is concerned. The notion of God as 'eminently real' is a favourite doctrine of Christian theology. The combination of the two into the doctrine of an aboriginal, eminently real, transcendent creator, at whose fiat the world came into being, and whose imposed will it obeys, is the fallacy which has infused tragedy into the histories of Christianity and of Mahometanism $[\mathrm{sic}] .{ }^{64}$

\footnotetext{
${ }^{63}$ Whitehead, Process and Reality, 47.

${ }^{64}$ Whitehead, Process and Reality, 342.
} 
He sees the idea of an eminently real, unmoved mover, derived both from Aristotelian metaphysics and traditional Christian theology, as suffusing and polluting the history of Christian thought. Theologians, by adopting Aristotle's designation of God as the unmoved mover, have sustained theological doctrines of God as above and beyond the actual world, rather than immanently related to the world. Such views have "infused tragedy" into the history of Christianity insofar as these views fostered the conceptions of God against which Whitehead argues in the opening pages of this final chapter-namely the images of God as imperial ruler, personification of moral energy, and ultimate philosophical principle. ${ }^{65}$ As I have described Whitehead's own understanding of God in this chapter, his dipolar conception of the divine cannot be reconciled with any of these positions, nor with the wedded notions of unmoved mover and eminent reality that he cites theologians as unceasingly striving to maintain.

In Adventures of Ideas, Whitehead writes of a New Reformation in protestant Christianity, a "re-formation" ${ }^{, 66}$ of ideas necessary for the development of religious thought and for the flourishing of civilization. He does not disavow the helpful assistance of systematic thought, but rather determines dogmatic finality to be the true enemy of theology, science, and metaphysics. ${ }^{67}$ In elucidating the development, as he sees it, of systematic theology, Whitehead distinguishes three phases: intellectual discovery, exemplification, and metaphysical interpretation. The first, intellectual discovery, he traces to Plato's formulation of divine power as persuasive rather than coercive. Mentioned briefly in a footnote in the first section of this chapter, Plato's enunciation attains a vital position within Whitehead's reformulation of God as dipolar. While Plato failed to systematically coordinate this insistence of divine power as persuasive (and indeed perhaps always failed in his attempts at systematization, as Whitehead charges), Whitehead attempts to

\footnotetext{
${ }^{65}$ Ibid., 342-343.

${ }^{66}$ Whitehead, Adventures of Ideas, 161.

${ }^{67}$ Ibid., 162.
} 
overcome this failure by ensuring that God's persuasive power relates systematically to his own speculative philosophy. The second phase in the development of a systematic Christian theology comes in the revelations of Jesus Christ, which he describes as revelations "of the nature of God and of his agency in the world." ${ }^{.68}$ Whitehead understands this phase as an articulation of the first phase - it is a divine enacting of persuasive power, in contradistinction to coercive power. He rather poetically portrays these revelations of persuasive power with the following lines: "The Mother, the Child, and the bare manger: the lowly man, homeless and self-forgetful, with his message of peace, love, and sympathy: the suffering, the agony, the tender words as life ebbed, the final despair: and the whole with the authority of supreme victory." ${ }^{, 69}$ The third phase can be summarized as the initial development of Christian theology in the early schools of the ancient near east, which were themselves immensely influenced by Platonic thought. Where this early theological development faltered, according to Whitehead, is in the subsequent development of a metaphysical system in which "the nature of God was exempted from all the metaphysical categories which applied to the individual things in this temporal world." ${ }^{70}$ This resulted in a gulf between God and the world, creating further problems - namely, the inability for humans to know what takes place on the other side of the gulf and the development of the notion of "unqualified omnipotence," requiring that God becomes responsible for the details of human existence (including, of course, the details of human suffering and tragedy). ${ }^{71}$

The problem with systematic or philosophical theology therefore lies in the creation of this gulf between God and the world, the insistence upon maintaining a clear distinction between the metaphysical rules applicable to God and the metaphysical rules applicable to the rest of the

\footnotetext{
${ }^{68}$ Ibid., 167.

${ }^{69}$ Ibid.

${ }^{70}$ Ibid., 169.

${ }^{71}$ Ibid.
} 
world. Instead of perpetuating this separation, Whitehead argues that theology should adhere to and develop an understanding of the world in which this metaphysical gap is eliminated. Insofar as it has failed to do so, he writes that "theology has largely failed.",72 Rather than claiming and explicating this re-formation, as Whitehead himself does, Christian theology has ossified, expressing an air of dogmatic finality.

These passages from Science and the Modern World, Religion in the Making, Process and Reality, and Adventures of Ideas illustrate Whitehead's reaction against theology as well as the reasons for this reaction. His argument in each text turns primarily around theology's tendency to rigidify its own claims into dogmatic claims resulting in stagnation and ossification. By developing a conception of God as dipolar, Whitehead enunciates a vision of God according to Plato's own early statement of divine power as persuasive and avoids creating a metaphysical gulf between God and the world. He proclaims theology's downfall in its failure to develop a coherent, systematic theology in which the same metaphysical statements are applicable to both. These arguments against traditional theology serve as warnings to be heeded as we move, in this project, toward a constructive Christian theology of remembrance. The theology I will develop in the coming section does not seek dogmatic finality, but evolves along with the flowing tide of temporal experience. I glean from Whitehead the importance of conceiving God as chief exemplification of the metaphysical system to which one adheres, rather than as the only exception to the system. Indeed, a theology that understands the intimate and complex relation among the past, present, and future cannot claim, with any integrity, the existence of a gulf between God and the world or between the past and the potential future out of which the present comes to be.

\footnotetext{
${ }^{72}$ Ibid., 170.
} 
Before moving into the final two chapters, which deal with post-Holocaust theology and with an articulation of a theology of remembrance, let me restate the significant points of Whitehead's notion of the dipolar God for the purposes of a post-Holocaust theology of remembrance. First, Whitehead's understanding of all events of the world as contained within God's consequent nature lends overwhelming support to the understanding that the deleterious past is not and cannot be effaced, forgotten, or mastered. Second, God as locus of the potentiality of the future provides the necessary conditions for the possibility of mastering the present by dealing directly with those aspects of the past and present that continue to perpetuate harmful ideologies, coercive political (and economic) power plays and both subtle and overt antiSemitism. Third, as we uncovered in the section illucidating Loomer's theology, the occasions constitutive of harmful aspects of the past, including the Holocaust, may be remembered without being redeemed in the traditional sense of transformation for some future purpose. In the final chapter, through Benjamin's instatiation of an inverse theology, we will see a way in which this remembrance (and nothing other than remembrance) might itself be viewed as redemption — not redemption into a transcendent abstraction, but redemption in the present, material or actual world. Finally, Whitehead's insistence that theology not exempt God from the metaphysical rules or perpetuate the notion of a chasm between God and the world imbues the post-Holocaust theology of remembrance outlined in the final chapter with the notion that God cannot be divorced from damaged life- the world in which one experiences horrendous suffering as well as intense joy. Rather, God's immanence in the world (as opposed to a transcendence of the world) must be seriously considered and articulated if we are to unfold a theology that refuses to betray the critical perspective of historical materialism. 


\section{Chapter 7: Theological Implications of Working Upon the Past and Mastering the Present}

In this chapter I will assess the theological implications of Adorno's and Voegelin's philosophical work, before turning to the wider field of post-Holocaust theology. First and foremost, both Adorno and Voegelin offer a caution to theologians and philosophers regarding the way in which we deal with the past. As this work up to this point has shown, we must not close the doors to the past, but must realize that we continue to encounter the past in the present, and the task of the final chapter of this project will be to develop a Christian theology that takes this injunction seriously. However, before doing so I will, in this chapter, first trace the theological impulses I find in Adorno and Voegelin with regard to the way in which the past comes to bear upon the present and, second, examine various theological responses to the Holocaust that have attempted to probe this relationship, including most notably the Jewish responses offered by Richard Rubenstein, Eliezer Berkovits, Emil Fackenheim and Emmanuel Levinas, as well as the Christian responses of Johann Baptist Metz and Clark Williamson. While one could write volumes on any one of these thinkers, my goal here will be to coalesce strands of their thought that deal specifically with the deleterious past and possibilities for remembrance. I begin with Adorno and Voegelin because they provide the impetus for critiquing the notion of Vergangenheitsbewältigung in the first place, and they offer necessary warnings and prohibitions that subsequent theologians and philosophers should heed if they are to avoid working through or mastering the past.

Recalling our discussion of working upon (rather than through) the past and mastering the present (as opposed to the past) in chapters one and two, we surmised that Adorno and Voegelin each see specific means for appropriately and affectively examining and remembering 
the past. For Adorno, working upon the past involves the task of critical self-reflection, while for Voegelin the process of mastering the present is nothing other than a spiritual endeavor, aimed at a moral and spiritual self-examination. Each of these procedures has strong theological implications, as I will point out in the following sections. Additionally, both Adorno and Voegelin (differently) require experience as the starting point for theological reflection. If theology is to adequately address the suffering of material reality or is to adeptly circumvent tendencies toward dogmatism, as Whitehead has demonstrated it must, then theology faces the requirement of taking experience into account. The first two sections below will examine these two pieces in turn, first in relation to Adorno and then in relation to Voegelin. The following two sections will then evaluate Jewish and Christian responses to the Holocaust (respectively) in light of the impulses offered by Adorno and Voegelin with respect to the problem of coming to terms with the past.

\section{Adorno's (Inverse) Theology}

Theodor Adorno maintained a somewhat strained relationship with religion and theology throughout his life. Born to a Jewish father and Catholic mother, Adorno became and remained largely an atheist. His associations with religion came primarily through philosophy, first with his Habilitationsschrift on Kierkegaard, completed under the supervision of Paul Tillich, and later through his critique of positive theology or revealed theology, as well as through his prolonged correspondence with Walter Benjamin. These three sundry strands demonstrate both his interest in and critical engagement with theology. As Christopher Brittain writes, Adorno discusses theology at points in his writing "because he thinks it reveals important insights into existing social conditions," and because he sees in (some) theology an expression of possible 
alternative social conditions. ${ }^{1}$ The writings of Adorno I will focus on in this section include, mainly, Negative Dialectics, his essay on "Reason and Revelation" written in 1957, and his letter to Walter Benjamin of 17 December 1934 in which he first invokes the term 'inverse theology.' While the latter sections of Negative Dialectics evidence Adorno's theological engagement with responses to the Holocaust, "Reason and Revelation" and his letter to Benjamin give the reader a more full sense of what Adorno thinks theology should and shouldn't be.

In Negative Dialectics Adorno discusses theology a scant few times, most of them appearing in the last section on "Meditations on Metaphysics" (the section on which his lectures on metaphysics were based). Here he describes, as detailed in chapter three, the various ways in which metaphysical reflection after Auschwitz must change if it is to remain at all tenable and appropriate. As I outlined in the chapter on Adorno's metaphysics after Auschwitz, he invokes a number of prohibitions in this text (and in the lectures) against continuing to do "metaphysics as usual," and it also becomes clear in these pages that the prohibitions extend to theology. Adorno offers the clearest interdiction in this regard when he writes: "After Auschwitz there is no word tinged from on high, not even a theological one, that has any right unless it underwent a transformation." As a result of this call for transformation after the events of Auschwitz, Adorno requires a return to experience as a source for philosophical and theological reflection (and in this regard becomes an interesting conversation partner for both Voegelin and Whitehead, as we shall see below). For Adorno, the experiences of lived reality must be taken into account if any theology that remembers the past is to become possible. Adorno expresses this most clearly as he writes of the transformation that must be undertaken in metaphysical reflection at the end of Negative Dialectics. Theological and metaphysical reflection must be transformed

\footnotetext{
${ }_{1}^{1}$ Christopher Craig Brittain, Adorno and Theology (New York: T \& T Clark, 2010), 2.

${ }^{2}$ Adorno, Negative Dialectics, 367.
} 
such that it takes into account the experiences of lived reality, especially the experiences of suffering by victims of the Holocaust and guilt by those who survived. He writes: "The mutual indifference of temporality and eternal ideas is no longer tenable..."3 This problem with traditional metaphysics, outlined in chapter three, extends also to the realm of theology. No longer can one maintain a notion of God as completely transcendent and outside of (as to say, not in relation with) the actual world — an understanding also articulated, as we have seen, by Whitehead through his dipolar conception of God and his critique of traditional theology.

Adorno is not clear in Negative Dialectics as to how theology might look after having undergone the required transformation; however, he is somewhat clearer on how it would not look. In one of the few places in which he directly addresses theology in the last part of Negative Dialectics (aside from the above mentioned injunction against continuing "theology as usual") he suggests that theology arose prior to metaphysics and that metaphysics secularizes theology into a concept, thereby preserving "theology in its critique, by uncovering the possibility of what theology may force upon men and thus desecrate." In the negative dialectic, metaphysics critiques the concept, which Adorno believes arose from theology in the first place, and makes clear or uncovers that which theology purports - that which theology all too often attempts to render as dogmatic finality, rather than the oscillation between concept and critique of the concept. Furthermore, in the same paragraph Adorno writes that the music of Beethoven and other great works of art "express hope much more powerfully than the traditional theological texts, and any such expression is configurative with that of the human side..."5 Theological treatises pale in comparison with their artistic counterparts in their ability to elicit hope in humanity precisely because Adorno finds possibilities for hope only on the human, material side

\footnotetext{
${ }^{3}$ Ibid., 361 .

${ }^{4}$ Ibid., 397.

${ }^{5}$ Ibid.
} 
of things, and decidedly not on the transcendent side: "Signs that not everything is futile come from sympathy with the human, from the self-reflection of the subjects' natural side..."6 These statements do not cast theology in a terribly positive light; nevertheless, Adorno's thought does not end in the total denigration of theology or the theological. He tells his reader here that any appropriate or non-futile theology must resist ossifying its own claims, and it must keep from seeking hope entirely in some transcendent or extra-historical realm. As a historical materialist, Adorno remains tied to explanations of the historical process that can be found within the material conditions of reality, and, as we shall see below with his concept of the messianic, redemption and hope cannot enter into the world from the outside, but must arise from within historical existence. ${ }^{7}$ Moreover, Adorno remains hopeful that both metaphysics and theology, if undertaken in the form of a negative dialectic, can in fact serve productive ends. As Brittain writes, "Adorno is convinced that forms of thought dismissed by modernity as 'metaphysical' or 'theological' not only remain legitimate, but are indeed required to challenge an increasingly irrational world."

If we return to his earlier writing in his 1957 essay entitled "Reason and Revelation" and his 1934 letter to Benjamin, we catch a clearer glimpse of what type of theology Adorno would be more inclined to support. In "Reason and Revelation" Adorno highlights significant problems with so-called revealed religion, citing its connection to economic powers engendering “societal hopelessness." His issues with revealed religion are several, but most significant for our purpose is the fact that he views revealed religion as favoring an appeal to transcendence as a move away from the suffering that arises within material reality. He writes: "The turn toward

\footnotetext{
${ }^{6}$ Ibid.

${ }^{7}$ Brittain, 132 .

${ }^{8}$ Brittain, 82.

${ }^{9}$ First published in 1969 in Stichworte.
} 
transcendence functions as a screen-image for immanent, societal hopelessness. Intrinsic to it is the willingness to leave the world as it is, because the world could not possibly be different." ${ }^{, 10}$ Reliance on revealed religion, he contends, serves only to confirm the already-established authoritative powers, reanimating the religious realm such that theological focus turns to the transcendent and away from the immanence of extreme suffering. Adorno's remedy for the type of irrational revealed religion that he criticizes comes in the form of ratio-reason as critical selfreflection - for only rational reflection incites even the hope of removing one from the social, political, and economic machines that promote ongoing suffering, thereby loosening the ties between revealed religion and the dominant systems.

The ratio or reason that Adorno proposes cannot be entirely conflated with the Enlightenment notion of rationality, or at least not with an unwavering support of rationality over against any other means of cognition. Adorno's Dialectic of Enlightenment articulates a process by which religion under the power of the Enlightenment divorced itself from superstition and myth in favor of enlightened rationality. However, Adorno and Horkheimer argue that such rationalization denuded Christianity (and here they address Christianity in particular) of its paradoxical nature (namely the irrational idea that God became human), thereby depriving it of its "moment of truth," preserving only its "reified forms." religion in the service of fascist nationalism and any other form of authoritarian "identity thinking"- the phrase Adorno uses for the type of thinking that is oblivious to its own totalizing tendencies. ${ }^{12}$ While the former aroused chief concern when Horkheimer and Adorno were writing Dialectic of Enlightenment, other authoritarian forms of thought, such as Capitalism,

\footnotetext{
${ }^{10}$ Theodor W. Adorno, "Reason and Revelation," in Critical Models: Interventions and Catchwords, trans. Henry W. Pickford (New York: Columbia University Press, 2005), 139.

${ }^{11}$ Horkheimer and Adorno, Dialectic of Enlightenment, 144.

${ }^{12}$ Brittain, 4.
} 
kindled Adorno's focus (I contend) in his essay "Reason and Revelation," written in the early 1960s when the threat of fascism had abated, or had at least been forced underground. As a result, the type of rationality promoted by the Enlightenment project became, in Adorno and Horkheimer's eyes, a myth the very likes of which it purported to dispel. As we have seen in previous chapters, it is for this reason that Adorno develops a negative dialectic, a type of metaphysical reflection that resists the temptation for metaphysical statements to reify themselves into truisms or statements of the absolute. In this regard, Christopher Brittain holds that "Adorno locates the 'need for religion' in the effort of reason to resist absolutizing itself.", Just as religion must be kept from absolutizing itself into dogmatic finality or into the very gears of the machine that maintains oppressive conditions (in whatever form they may appear), so too must reason guard against absolutizing itself into the Enlightenment modes of thought that he and Horkheimer criticized so vehemently in Dialectic of Enlightenment.

The task of reason in the service of religion today, according to Adorno, must be to bridge the dichotomy between the biblical origin of revealed doctrines and the contemporary situation. ${ }^{14}$ As an example of this dichotomy, Adorno asserts that the New Testament concept of daily bread in a world of insufficient food production cannot be reconciled with a Western reality in which surplus production is the norm. Yet if the revealed doctrines are adapted to the contemporary situation, then they run the risk of being made incompatible with the authority of revelation. If they are not adapted, but allowed to remain incommensurable, then the doctrines are either beyond realization or fail to account for the "most essential concern, the real suffering

\footnotetext{
13 Brittain, 51.

${ }^{14}$ I see interesting parallels to Paul Tillich here, with whom Adorno worked both as a student and as a member of the Institute for Social Research. Tillich's method of correlation seeks to correlate the eternal message with the temporal situation. The difference between Tillich and Adorno seems to arise from the fact that for Adorno the revealed doctrine is not timeless unless it can respond to present suffering under the conditions of material reality.
} 
of people."15 This real suffering, damaged life itself, must remain the focal point of religion if it is to have any bearing whatsoever on the present circumstances. Otherwise revealed religion remains entrenched in the historical situation of its origin without any hope of correspondence to the lived reality of its adherents. Thus, Adorno signals for the latter-revealed doctrines must be adapted to the contemporary situation via rational, critical self-reflection so as to foster concern for the real suffering of people. His statement at the end of "Reason and Revelation," known as the Bilderverbot, provides an imperative for such adaptation. He writes: "Therefore, I see no other possibility than an extreme ascesis toward any type of revealed faith, an extreme loyalty to the prohibition of images, far beyond what this once originally meant."16 Adorno does not invoke the Bilderverbot as an apophatic move, but rather because any recourse to a divine image ends only in reification by the prevailing social, political and economic systems. The prohibition thus remains in line with his earlier critiques of revealed religion as a turn toward transcendence and away from real suffering, and it emphatically resists any possibility for reification of the divine image under authoritarian or other interests.

Alongside the Bilderverbot, Adorno offers an additional injunction that forces religion to swerve toward materialist concerns. Earlier in "Reason and Revelation" he charges that "[n]othing of theological content will persist without being transformed; every content will have to put itself to the test of migrating into the realm of the secular, the profane." ${ }^{\prime 7}$ His statement here is not far from the previously cited injunction that appears at the end of Negative Dialectics. In both instances his intention is clear: theology must address the concerns of material reality, the suffering of real people. Whether addressing fascism, nationalism, Capitalism, or the Holocaust, Adorno's historical materialism inverts theology from a gaze upon the divine to a

\footnotetext{
${ }^{15}$ Adorno, "Reason and Revelation," 142.

${ }^{16}$ Ibid.

${ }^{17}$ Adorno, "Reason and Revelation," 136.
} 
gaze upon damaged life from the perspective of the divine, and this inverted gaze is the premise of his notion of inverse theology.

The phrase inverse theology first appears in a letter from Adorno to Walter Benjamin dated December 17 of 1934 in which Adorno writes to praise Benjamin's essay on Kafka. The Kafka essay, published in partial form in two issues of the Jüdische Rundschau that month, dealt with various aspects of Kafka's writing and included a brief commentary on the short story "The House-Father's Concern." From their correspondence it is evident that Adorno requested and read a copy of the essay sent to him by Benjamin just prior to its publication. The December 17 letter demonstrates Adorno's obvious enthusiasm for the essay, stemming at least in part from his recognition of a deep agreement between Benjamin's philosophy and his own. Adorno summarizes his own "earliest attempts" at an interpretation of Kafka with the following: "I claimed he represents a photograph of our earthly life from the perspective of a redeemed life, one which merely reveals the latter as an edge of black cloth, whereas the terrifyingly distanced optics of the photographic image is none other than that of the obliquely angled camera itself..."18 He contends that Benjamin's interpretation of Kafka and theological glosses on the author's work align completely with his own, striking a position that "could indeed be called an 'inverse' theology."19 This position, he writes, takes its stand "against natural and supernatural interpretation alike," and is decidedly not a dialectical theology. ${ }^{20}$

The largely enigmatic description of inverse theology insists upon assuming the perspective of the divine in order to peer through an "obliquely angled camera" at the harsh

\footnotetext{
${ }^{18}$ Theodor W. Adorno, "Berlin, 17 December 1934," in Theodor W. Adorno and Walter Benjamin: The Complete Correspondence 1928-1940, ed. Henri Lonitz and trans. Nicholas Walker (Cambridge, MA: Harvard University Press, 1999), 66.

19 Ibid., 67.

${ }^{20}$ The allusion to dialectical theology is a nod toward Hans Joachim Schoeps, who wrote commentary on Kafka as expressing religious views in line with those of the dialectical theology of Barth. Here Adorno means that his reading of Kafka and his own 'inverse theology' cannot be equated with the dialectical theology of Barth, which I suggest he would also equate with revealed religion.
} 
reality of material existence. The only depiction of the divine that inverse theology ventures is that of an "edge of black cloth," a descriptor that is itself inscrutable and noncommittal. Nevertheless, inverse theology does not intend any concealment of the divine. Adorno and Benjamin resist kataphatic and apophatic perspectives alike, preferring to say as little as possible about the divine, while also eschewing movements that prohibit suppositions altogether. Instead, their focus remains on earthly, damaged life itself, which to be sure represents the (as yet) unredeemed. It is this damaged human existence that demands theological attention. As Elizabeth Pritchard notes: "Inverse theology 'feigns' the divine or angelic standpoint in order to see the fallenness of the world. The point is not to veil the absolute, but to unveil a broken world."21

Viewing earthly life from the perspective of the redeemed results in a depiction of material reality as damaged life. Since one has already assumed the redeemed perspective one knows that damaged life is not all there is or all that must be. However, as Pritchard points out, there is no path from earthly reality to a redeemed existence that does not go directly through the suffering of this world. She remarks, "being able to see that things should not be as they are does not thereby allow one to produce a picture of the way things should be or will be.,"22 Adorno's historical materialism results over and over in his refusal to move dialectically toward the absolute while forsaking the experiences of lived reality. His criticism of metaphysical systems that seek their end in concepts assumes utmost importance after Auschwitz, as I have shown, when temporal experience can no longer be reconciled with eternal ideas. And his materialism has provided the basis for such statements all along, beginning with the 1934 letter to Benjamin in which he invokes the term inverse theology.

\footnotetext{
${ }^{21}$ Elizabeth A. Pritchard. "Bilderverbot Meets Body in Theodor W. Adorno's Inverse Theology," in Harvard Theological Review 95, no. 3 (2002): 309.

${ }^{22}$ Pritchard, 303.
} 
Implicitly following Marx’s dictum in his "Theses on Feuerbach" that "Philosophers have only interpreted the world in various ways; the point is to change it," ${ }^{, 23}$ Adorno articulates a materialist theology that requires transformation from the present conditions, as conditions that engender extreme suffering, into some altered state in which suffering might be diminished or eliminated. Again, Elizabeth Pritchard notes: “Adorno's use of the term 'prolegomenon' [in his letter to Benjamin] suggests that his inverse theology should be understood as forward-looking and potentially transformative." 24 Indeed, Adorno mentions Benjamin's description of the position of scripture for Kafka, claiming that what Kafka viewed as a relic of scripture should instead be understood as a prolegomenon to scripture. In social terms, precisely the way in which Adorno reads these notions of Benjamin, reason as critical self-reflection becomes the prolegomenon, a critical or discursive introduction to the potentially altered state. Pritchard herself makes exactly this point, though I wish to tie it more directly to Adorno's essay on "Reason and Revelation." Critical self-reflection must stand as the hermeneutical forerunner to revelation so to be able to correspond what is revealed to the present situation within material reality. In this sense reason as a critical capacity becomes the very lens of the obliquely angled camera through which damaged life must be viewed, and when revelation passes through this lens, casting its gaze upon the immanent suffering, then it undergoes the type of transformation required by Adorno in the injunctions previously cited. As Christopher Brittain reminds us:

In this critical process of reflecting upon existing social conditions for the sake of rescuing for the present what is repressed and veiled by these conditions, Adorno states that everything must be viewed in light of a possible future. Suffering is understood to reveal that a just society is not presently found in existing social conditions. ${ }^{25}$

\footnotetext{
${ }^{23}$ Karl Marx, "Theses on Feuerbach," in The Portable Karl Marx, ed. Eugene Kamenka (New York: Penguin Books, 1983), 158.

${ }^{24}$ Pritchard, 307.

${ }^{25}$ Brittain, 74-75.
} 
This theological transformation into an inverse theology then announces the possibility of a material transformation of damaged life into what one might term redeemed life.

\section{Voegelin and Theology}

Voegelin, in contradistinction to Adorno, offers a different account of theology and an alternate understanding of the significance of transcendence. I will not attempt to reconcile their differences, but only point out their places of divergence, since both positions ultimately provide, when combined with Whitehead's own conception of the divine, fruitful components for what will become a theology of remembrance. This section will first probe Voegelin's injunction against "immanentizing" the eschaton as it appears in The New Science of Politics before turning to his call for a spiritual self-examination as a part of mastering the present (as a presence under God). By first examining the process of dedivinization and redivinization that devolves into an immanentization of the eschaton, we will be able to see more clearly how a spiritual selfexamination in the present may be carried out in a manor that conforms to Voegelin's discussion of representational politics and the participation in a transcendent divine. Finally, I will also return to the tension between Adorno and Voegelin's views on appeals to transcendence in order to illuminate the different approaches each takes to the theological.

In his book The New Science of Politics, Voegelin includes an alluring description of Gnosticism as suffusing modernity and modern political society. The Gnostic Prophet arrives in what Voegelin refers to as the third symbol in a trinity of symbols that come as a result of the process of dedivinization. If we recall the discussion of dedivinization covered in chapter two, we remember that dedivinization signifies a refusal on the part of humans to participate in the divine through either reason or spirit. In The New Science of Politics, the process of dedivinization results in a replacement of the transcendent divine with the (theo)political 
institution of the Christian church (via Augustine), which in turn leads to the articulation of society into spiritual and temporal orders. ${ }^{26}$ From this new order, a process of redivinization occurs that inaugurates a combination of symbols that Voegelin analyzes in terms of Joachim of Flora. The symbols are, first, "the conception of history as a sequence of three ages, of which the third age is intelligibly the final Third Realm, ${ }^{, 27}$ second, the enunciation of a leader of the realm, third, the realization of a Gnostic prophet of the new age, and finally, the arrival of a "brotherhood of autonomous persons." 28 This redivinized socio-political order gives way to a Gnostic flavor insofar as it appropriates a secret or mysterious knowledge as necessary for realizing an eschatological realm.

In Voegelin's eyes, the Third Reich, Hitler's Nazi Germany, exhibits the symbols of such a redivinized society under a gnostic stance because it pronounced itself as a third age (Third Reich), identified a clear leader and Gnostic prophet, and maintained sole control over the hidden truth or the secret knowledge necessary for realizing some German, mythic eschaton on earth. The Nazis' attempt at inaugurating Aryan "purity" into an expanded German nation, and their militarily administered task of German expansionism in order to create Lebensraum (room for living) in their empire exhibit this desire to establish an extra-worldly envisagement within the finite conditions of material reality. Voegelin vehemently decries such an attempt at immanentizing the eschaton: "Such an immanentist hypostasis of the eschaton...is a theoretical fallacy." ${ }^{29}$ Moreover, one significant problem with such an immanentization lies in the fallacious assumption of an eidos of history. History, for Voegelin, exhibits no coalescing characteristic "because the eschatological supernature is not a nature in the philosophical,

\footnotetext{
${ }^{26}$ Voegelin, The New Science of Politics, 110.

${ }^{27}$ Ibid., 111.

${ }^{28}$ Ibid., 112.

${ }^{29}$ Ibid., 120.
} 
immanent sense" and "because the course of history extends into the unknown future." Eschatological visions in Christianity cannot be invoked as realizations on earth in this temporal order, and the attempt to immanentize the eschaton in this manner leads to disastrous consequences, as evidenced by the attempts of the National Socialist Third Reich. Describing the Gnostic tendencies of revolutionary groups, such as National Socialism, Voegelin writes: "These Gnostic experiences, in the amplitude of their variety, are the core of the redivinization of society, for the men [sic] who fall into these experiences divinize themselves by substituting more massive modes of participation in divinity for faith in the Christian sense. ${ }^{.31}$ Thus, the redivinization, which is always a false divinization, attempts to endow the leader of the realm or the Gnostic prophet with divinity so that a "more massive" participation in the divine occurs. This massive participation as a result of false redivinization must be separated from the participation in the divine that Voegelin sees as correctly and appropriately providing the foundation for his representational politics. The difference, of course, is that in the representational process one participates in the actual transcendent divine, whereas in redivinization one participates in an immanent, temporal leader who claims aspects of divinity for him/herself.

Voegelin's emphasis on founding the political order on the transcendent divine cannot easily be reconciled with Adorno's emphasis on the material world, eschewing attempts at seeking redemption from some extra-worldly source. Almost as if in rebuttal to Adorno's "inverse theology," Voegelin argues that "Gnostic speculation overcame the uncertainty of faith by receding from transcendence and endowing man and his intra-mundane range of action with

\footnotetext{
${ }^{30}$ Ibid.

${ }^{31}$ Ibid., 124.
} 
the meaning of eschatological fulfilment [sic]. ${ }^{32}$ However, I speculate that Adorno would respond by reminding his readers that he (unlike other Marxist thinkers of his time) never sought to realize a utopian order in the Marxist sense, and therefore, he never aimed as establishing an eschatological order within material reality. No complete harmonization of Adorno and Voegelin on the role of transcendence is possible, nor would a harmonization prove at all productive anyway. Nevertheless, I suggest that Adorno's inverse theology should not be viewed as a Gnostic movement, since it blatantly refused to admit the possibility of an eschatological realm within the material world. To be sure, Adorno hopes that some better possibilities might be realized for damaged life, but he never formalizes such possibilities into redivinized conceptions that (falsely) claim divine authority. To repeat Brittain's assertion cited above, Adorno in no way appeals to an extra-worldly source in order to bring about the redemption of the world. Again, this point both protects Adorno from Voegelin's critique of Gnostic tendencies, which he levels at Marxism in general, and places him in tension with Voegelin's own appeal to a transcendent divine as the true basis for representational power and as the orienting point under which the present might be mastered.

In his introduction to the edited volume of Voegelin's "Hitler and the Germans," Detlev Clemens writes: "Since the past cannot be altered after the event, the 'mastering of the present,' in Voegelin's eyes, was largely a problem of moral consciousness and therefore inevitably demanded a relentless spiritual self-examination of their past and present by Germans." Mastering the present requires a spiritual self-examination and, therefore, has theological consequences, or comes to bear or impinge upon theology in some way. Here I wish to elucidate exactly what these theological consequences may be for a post-Holocaust theology, some 70 years after the fact. The next chapter will address more specifically the question: how can a

\footnotetext{
${ }^{32}$ Ibid., 129.
} 
Christian post-Holocaust theology aid in mastering the present in such a way that it promotes and fosters a spiritual self-examination? For now, I will provide a summary of Voegelin's own thoughts on the process, however tentative they may be.

As I outlined in chapter two, Voegelin claims that humanity must realize its present as a presence under God, and this realization constitutes mastery of the present, which should be the true goal of those who wish to examine (without mastering) the unmastered past. The process by which one realizes oneself as present under God requires a spiritual examination — an examination of the spiritual and moral qualities of oneself and a critical evaluation of the orienting principles present in one's life. One must see oneself as oriented and guided by a transcendent divine, which Voegelin conceives as the Christian God, in order to correctly and appropriately realize and function within this presence under God. Recognizing and accepting such an orientation does two things: first, it keeps one from elevating a non-divine substitution, such as the Gnostic prophet or leader of the realm, to the status of orienting principle; and second, it conditions the manner in which one acts, judges, and responds to events in the world. With regard to the first, Voegelin wants to guard against the deleterious effects of redivinization through a false temporal leader or Gnostic prophet, such as those effects brought about by Hitler and the National Socialists. Elevation of such Gnostic movements to the status of divine would only continue the cycle of past events, a cycle which both he and Adorno seemed to see as a distinct possibility in the first two decades following the Second World War and the downfall of National Socialism. Moreover, repeated reliance on these Gnostic movements fails to actually master the present, seeking instead only to master the past through the same alibi procedures uncovered in chapter two. Regarding the second, to repeat an assertion made in his "Lectures on Hitler and the Germans," Voegelin notes that the sense of "being-under-judgment" under the 
presence of God causes one to "adjudicate how he [sic] acts and how others act and how this action brings about an order of society." 33 The goal is not only to act in a manner that would cause one to be judged positively by God, but to act in a manner that structures and orders society through participation in the transcendent divine by virtue of this orienting principle of realizing one's presence under God.

Somewhat similar to Adorno, Voegelin calls for a theology grounded in experience, arguing for theologians to consider the range of experiences from the tradition's foundation up to one's own experience as theologian, or as interpreter of experience. Without experience as the starting point for theology, theologizing devolves into the dogmatization that for him marks the downfall of Western society. Moreover, Voegelin recognizes an ever-present tension when entering into the theological realm, a tension that manifests itself as the metaxy (a term he borrows from Plato) — the in-between of reality or of the "divine-human metalepsis." "34 Revelation occurs within this metaxy and thus the "content of revelation cannot be separated from its personal facticity, i.e., the event of its occurrence and interpretation in the soul of the recipient." ${ }^{35}$ In the ossification or dogmatization of revelation, recognition of this in-between is lost and (Christian) society thus becomes dedivinized. Accordingly, Michael Morrissey characterizes the aim of Voegelin's theological project: "to recover the experience of the 'mystery' from underneath the centuries-long process of dogmatizing obfuscation, and to regain its truth for all human beings." 36 For this reason, Voegelin remains unconcerned with subsequent church doctrine and dogma, focusing instead on "the experiential core" of

\footnotetext{
${ }^{33}$ Voegelin, "Hitler and the Germans," 71.

${ }^{34}$ Michael P. Morrissey, Consciousness and Transcendence: The Theology of Eric Voegelin (Notre Dame, IN: University of Notre Dame Press, 1994), 233.

${ }^{35}$ Ibid., 234.

${ }^{36}$ Ibid., 235.
} 
"revelatory truth." ${ }^{37}$ Such a stance may be glimpsed in Voegelin's understanding of Christology as outlined by Morrissey. Again, Voegelin is unconcerned with church dogmatics and orthodox views of the Trinity and Christology and more (or solely) concerned with the divine presence in human consciousness revealed through the person and work of Christ: "the intelligibility of incarnation has less to do with a preexistent divine person that became flesh...than the emergence of divine presence in human consciousness, which is a historical process, not a onetime event." ${ }^{38}$ Thus, Voegelin views incarnation less as a specific moment in Christian history and more as a "spiritual fulfillment of the created order of the human being who is created in God's image," ${ }^{39}$ or in simpler terms incarnation is the realization of the divine presence in humanity and facilitates a human participation in the divine.

In both Voegelin and Adorno, experience remains a vital starting point for theological reflection, and this point proves significant as we seek after types of theological reflection appropriate after the Holocaust and in light of the problem of coming to terms with the past. For Voegelin, "any serious inquiry into reality must be rooted in human experience." 40 Therefore, if we begin from experience in response to the atrocities of the Second World War, addressing the experiences of suffering in the Holocaust and the experiences of shame and guilt on the part of many Germans results in the need for mastering the present, which is a "presence under God." For Adorno, the model of an inverse theology also remains rooted in experience, moving him toward a glimpse of a better world without leaving behind the victims of suffering and oppression — namely victims of the Holocaust. In each thinker, the tension between the divine and human and between the origin of revelation and its application in specific moments of

\footnotetext{
${ }^{37}$ Ibid.

${ }^{38}$ Ibid., 238.

${ }^{39}$ Ibid.

${ }^{40}$ Ibid., 247.

${ }^{41}$ Voegelin, Hitler and the Germans, 70.
} 
human history orients humanity toward the possibility of moving into a less deleterious future, while also remembering the horrific events of the past.

\section{Jewish Responses to the Holocaust}

Since the 1960s, a number of Jewish religious thinkers and philosophers have attempted to respond to the horrific suffering of the Holocaust, and in so doing have raised various questions, such as to what extent the Holocaust may be called a unique event and whether or not focusing on theodicy remains a fruitful effort in the post-Holocaust world. This section will briefly explore the post-Shoah theological positions of Richard Rubenstein, Eliezer Berkovits, Emil Fackenheim, and Emmanuel Levinas. I seek to glean theological insights from these thinkers who have thoroughly and rigorously rethought the divine-human relationship and the theological implications of extreme human suffering in light of the Holocaust, and I do so with the aim of arguing that Christian theology must also deal comprehensively with the historical rupture of the Holocaust in similar (though perhaps not identical) ways. These three theological positions represent, to a large degree, the wide spectrum of post-Holocaust responses, and therefore give readers a sense of the range of possible responses.

Richard Rubenstein's After Auschwitz appeared in 1966 as the first major, overt Jewish theological response to the Holocaust. His writing was not well received by the Jewish academic or religious community, largely because it was seen at the time as a radical revision of Judaism and a rejection of the major tenets of Jewish faith. Indeed, Rubenstein's stance was radical in that it proclaimed the "death of God" and the end of omnipotence. Zachary Braiterman summarizes Rubenstein's argument as follows: "to posit a just and omnipotent God covenanted to Israel and active in its affairs could only mean that God justly willed the murder of six million 
Jewish people." ${ }^{42}$ Thus, the only possible explanation remaining must be, for Rubenstein, that God is no longer active in the affairs of the people of Israel. In Rubenstein's own words, we see him rebelling against the logic of omnipotence in the light of horrendous suffering:

The tendency of the Church to regard Jews in magic and theological terms encourages the view that the vicissitudes of Jewish history are God's will. If we accept [this premise], there is no way of avoiding... [the notion that] God sent Hitler. But how can we ask Christians to give up these premises if we continue to regard ourselves in this light? ${ }^{43}$

If Jews are to critique Christians for proclaiming anti-Semitic views in the name of the God of History, then shouldn't Jews, he asks, also re-examine their claims based on the God of History? In fact, the God of whom Rubenstein decries the death is of the God of History-the God who "represents the perfect, immutable Creator who remains outside of and apart from the world and its history in a stance of omnipotent control and judgment. ${ }^{, 44}$ As Braiterman clarifies, Rubenstein does not herald the death of God in the same way that Protestant theologians did in the 1960s (such as, most famously, Thomas Altizer) because he is not addressing an existential crisis in which human freedom cannot be reconciled with an all-powerful God. Rather, he describes the death of God from the purview of human suffering, arguing that there is no longer any relation between the divine and humanity, as evidenced by the events of Auschwitz.

From these statements, Rubenstein goes on to articulate how Jewish religion, and even a notion of God, can survive the "death of God" by returning to a form of "insightful paganism," seeking spiritual renewal and fortitude in earthly images. He reconceives God as intimately involved in creation as the ground of being (not far from Tillich's own understanding of God as the ground of being), adopting a panentheistic stance as a vision of the world contained within

\footnotetext{
${ }^{42}$ Zachary Braiterman, (God) After Auschwitz: Tradition and Change in Post-Holocaust Jewish Thought (Princeton, NJ: Princeton University Press, 1998), 87. Emphasis in original.

${ }^{43}$ Richard Rubenstein, After Auschwitz: Radical Theology and Contemporary Judaism (Indianapolis, IN: BobbsMerrill Publishing, 1966), 58. Also quoted in Braiterman, 90.

${ }^{44}$ Braiterman, 92.
} 
God's being. ${ }^{45}$ His reconception of Judaism and of God also includes a deeply mystical element, referring to God as "Holy Nothingness," over against the ambiguous world in which humans find themselves, reminding us of Loomer's "size of God" in which the ambiguity of the world is recast as the ambiguity of God. ${ }^{46}$ These revisions of Jewish religion and theology after the Holocaust make a couple of promising moves, including shifts away from a completely omnipotent and/or transcendent God. Additionally, Rubenstein eschews traditional theodicy, the attempt to explain human suffering while maintaining a notion of an all-powerful and good God. Nevertheless, he doesn't offer, as Adorno and Voegelin attempt to do, any possible conception of a better world, but suggests that we must be content with the world as it is (in terms strikingly similar to Bernard Loomers').

Eliezer Berkovits, a liberal Orthodox Jew (if such self-contradictory description is possible), rejects Rubenstein's announcement of the death of God, while also rejecting mainstream Orthodox views of the Holocaust as God's divine punishment. As Braiterman suggests, Berkovits became a "subtle revisionist" ${ }^{\text {"47 }}$, re-imagining Jewish life and practice in light of a horrendous and unique event. This subtle revision rebuffs the radical stance of Rubenstein by asserting that only one who actually experienced the atrocities of the Holocaust has the right to herald the death of God. Those writing about the events, who did not actually experience the events, can not and dare not make such claims. ${ }^{48}$ Instead, Berkovits writes of God's hiding, or God's absence in the face of the events of Auschwitz. This absence is a distance that respects and maintains human freedom, the very basis of human existence without which humans would cease to be humans. If God were to enter history in order to stop evil from occurring, then God

\footnotetext{
${ }^{45}$ Ibid., 95.

${ }^{46}$ Rubenstein, 80.

${ }^{47}$ Braiterman, 115 .

${ }^{48}$ Eliezer Berkovits, Faith After the Holocaust (New York: KTAV Publishing House, 1973), 3-4.
} 
would obviate human freedom and thereby destroy the very essence of humanity. This position leaves Berkovits with the following paradox, noted by Braiterman: "On the one hand, God withdraws from world history so as not to overwhelm human freedom. On the other hand, God must enter history and save humanity from its own undoing." ${ }^{49}$ The paradox, which can also be expressed as a tension between theodicy and anti-theodicy ${ }^{50}$, however, is absolved later in Faith after the Holocaust when Berkovits argues that ultimately messianic redemption justifies the suffering of the people of Israel in the Holocaust. Here he writes: “...nothing of the sorrow and the suffering was in vain, for all the time the path was being paved for the Messiah. Not a single tear was wasted, for all of it will be vindicated in his coming. Only messianic redemption can lend meaning and bring justification to Israel's martyrdom. ${ }^{, 51}$ With this statement, Berkovits moves decisively back into the realm of theodicy, justifying Israel's suffering with the progressive movements (read as messianic movements) toward a free Jewish state in Israel.

As a result of his ultimate return to theodicy, Berkovits does not lend a sufficient transformation of the notion of God to the post-Holocaust discussion. He does retain a very real sense in which Jews can anticipate a fully redeemed future, but his attempt to redeem the suffering of the Holocaust does not square with the theology I attempt to propose for Christians in this work as a theology that remembers the suffering of the past without overcoming or mastering horrendous evils of the past. With this in mind, we move to a discussion of Emil Fackenheim's philosophy as perhaps a more fruitful position located between Rubenstein and Berkovits.

\footnotetext{
${ }^{49}$ Braiterman, 119.

${ }^{50}$ The term anti-theodicy is used by Zachary Braiterman in his work (God) After Auschwitz, from which parts of my summations of Rubenstein, Berkovits and Fackenheim are drawn.

${ }^{51}$ Berkovits, 152.
} 
In his book (God) After Auschwitz, Zachary Braiterman describes the antinomy between the positions of Rubenstein and Berkovits, suggesting that Fackenheim articulates a position that may be a middle ground between the two. ${ }^{52}$ I agree with Braiterman's characterization and hold that Fackenheim's position, out of the three, lends itself most successfully to a theology of remembrance. As such, his philosophical writings on the Shoah provide the most helpful insights for Christians who wish to adequately deal with the deleterious past of the Holocaust. Fackenheim's post-Shoah thinking appears primarily in two texts published in 1970 and 1982 respectively: God's Presence in History and To Mend the World. In the first, Fackenheim begins from the position that "no meaning, redemptive or other, religious or secular, will ever be found in the Holocaust. ${ }^{, 53}$ From this starting point, he goes on in the preface to inaugurate a $614^{\text {th }}$ commandment, a contemporary addition to the 613 commandments of the Torah. The new commandment — the prohibition against giving Hitler any posthumous victories—can be seen in a similar light with Adorno's new categorical imperative insofar as it provides an orienting principle to all future actions and statements from the purview of the Holocaust. The $614^{\text {th }}$ commandment encourages Jews to "carry on in spite of [Hitler]," which means that Jews must not give up on Jewish religion or tradition in the wake of the Holocaust because to do so would provide Hitler and the Nazis with a posthumous victory in the form of the eradication of Judaism. ${ }^{54}$ In order to exhibit a way in which Jews might faithfully follow this new commandment, Fackenheim returns to the Midrashic framework as a means for rethinking the God of history.

\footnotetext{
${ }^{52}$ Braiterman, 9.

${ }^{53}$ Emil L. Fackenheim, God's Presence in History: Jewish Affirmations and Philosophical Reflections (Northvale, NJ: Jason Aronson, Inc., 1997), x.

${ }^{54}$ Ibid., xii. Emphasis in original.
} 
Fackenheim's Midrashic framework includes five features: 1) a reliance and reflection upon the Jewish root experiences (those experiences that served as foundational to historical Judaism), 2) a realization that these root experience contain contradictions, 3) a refusal to destroy the root experiences, 4) acceptance of the fact that the contradiction cannot be overcome, but merely expressed, and 5) an understanding that the only adequate literary forms for the Midrashic framework are those of story, parable, and metaphor. ${ }^{55}$ Thus, this framework draws from historical Judaism and embraces the contradictions arising in its history, and Fackenheim maintains that the root experiences of the past give voice to the present and "legislate to the present" through the Midrashic framework. ${ }^{56}$ As he describes God's presence in history vis-á-vis these past root experiences, Fackenheim writes of God's presence as a commanding presence, terming this presence the commanding voice of God. In order to articulate the commanding presence, he first notes "if God is ever present in history, this is not a presence-in-general but rather a presence to particular men [sic] in particular situations." ${ }^{, 57}$ Thus, one must return to the events at Sinai in order to understand the commanding presence - a historical presence that was present to particular people in the historical events at Sinai. At Sinai God's presence took the form of a commanding presence, providing Israel with certain commandments by which to live, the result of which is that "except for a commanding Presence, any divine Presence in history remains, for Jewish experience, at best fragmentary." ${ }^{58}$ God's commanding presence provides the means by which Fackenheim retains the God of history as an essential feature of his postHolocaust religious option.

\footnotetext{
55 Ibid., 20.

56 Ibid., 9.

${ }^{57}$ Ibid., 8. Emphasis in original.

${ }^{58}$ Ibid., 14.
} 
In To Mend the World, Fackenheim writes that after the Holocaust Judaism must affirm some sense of historicity ${ }^{59}$, and that if one loses the disclosure of the God of history in the present, then God is lost. ${ }^{60}$ The loss of the God of history would, for Fackenheim, also entail the loss of the commanding voice that calls the Jewish people to endure after and in spite of the Holocaust. The commanding voice hearkens back to the voice of God experienced by Israel at Sinai, a voice that was (in that instance) a commanding voice. He articulates this commanding voice more fully in God's Presence in History as the commanding voice of Auschwitz, a commanding voice that speaks from Auschwitz. This commanding voice imposes fragmentary injunctions, including: 1) the duty of Jews to remember and tell the tale of Auschwitz, a duty that is not negotiable, but holy ${ }^{61}$; 2) the duty of Jews to survive and reject any notion that Judaism is anachronistic; 3) the commandment "not to abandon the world to the forces of Auschwitz, but rather to continue to work and hope for [the world]" ${ }^{\prime 62}$; and 4) the commandment to continue wrestling with God after the Holocaust, while simultaneously refusing to use the Holocaust as a weapon by which to deny God. ${ }^{63}$ The result of these fragments is a paradox: one must remember the Holocaust and remember the suffering of the past, but one must also refrain from entering into a state of perpetual mourning from which there is no relief. For Fackenheim, Jews cannot move past the Holocaust, lest the Holocaust be overcome or mastered, but Jews also must not be subdued by the weight of the Holocaust, for allowing such subjugation would amount to handing Hitler a posthumous victory. As a way of walking the thin line between these two

\footnotetext{
${ }^{59}$ Emil L. Fackenheim, To Mend the World: Foundations of Post-Holocaust Jewish Thought (Bloomington, IN: Indiana University Press, 1982), 94.

${ }^{60}$ Fackenheim, God's Presence in History, 79.

${ }^{61}$ Ibid., 85-86.

${ }^{62}$ Ibid., 87.

${ }^{63}$ Ibid., 88.
} 
possibilities, he suggests that the commanding voice of Auschwitz must be heard as an injunction to endure. Fackenheim writes at the end of God's Presence in History:

we are here, exist, survive, endure, witnesses to God and man [sic] even if abandoned by God and man [sic]. Jews after Auschwitz will never understand the longing, defiance, endurance of the Jews at Auschwitz. But so far as is humanly possible they must make them their own as they carry the whole Jewish past forward into a future yet unknown. ${ }^{64}$

Fackenheim's commanding voice leaves Jews with a tall order—carrying the past of an entire people into an uncertain future is no small burden. Yet, for him, this is the only way to carry on as Jews without either overcoming the Holocaust or being overcome by the Holocaust.

What Fackenheim outlines in God's Presence in History and To Mend the World demonstrates two points I find particularly insightful for building a theology of remembrance. First, Fackenheim disavows the possibility for theodicy after Auschwitz. Theodicy, the attempt to explain evil events alongside God's goodness, is simply not an exercise Fackenheim is interested in pursuing. Instead, given the Midrashic framework from which he works, the tension between these two antipodes does not need to be and must not be explained, since any explanation aims only at explaining away the fragmentary nature of Midrashic thought (which is further the fragmentary nature for a future that can only be perceived in fragments). Additionally, he writes that any reliance on theodicy as a response to the Holocaust is entirely untenable inasmuch as theodicy attempts to overcome the harmful past. He argues, instead, "where the Holocaust is there is no overcoming; and where there is an overcoming the Holocaust is not." ${ }^{, 65}$

To overcome the Holocaust would not do justice to its victims, and moreover, such an overcoming is simply not possible. Fackenheim spends several pages in the middle of his chapter on the "Shibboleth of Revelation" discussing what it might mean to overcome the Holocaust and then explores various strands of Western thought (Hegelianism, left-wing

\footnotetext{
${ }^{64}$ Ibid., 97-98.

${ }^{65}$ Fackenheim, To Mend the World, 135. Emphasis in original.
} 
Hegelianism, and neo-Orthodox Christianity) that either provide the framework for overcoming or in fact attempt to overcome the Holocaust. For Fackenheim, the Hegelian move of negating the negation amounts to overcoming that which negates in the first place. Thus, any Hegelian move aims at sublation, which is an overcoming, as we have seen in Adorno's critique of the positive dialectic. To tie this directly to theodicy, the attempt at a systematic explanation of evil in the world cannot withstand his critique of overcoming because that which appears as and must remain fragmentary becomes either effaced or somehow systematized (and thus no longer maintains the contradictions of Midrashic framework). "To 'overcome,' 'transcend' or 'go beyond' our fragmented, momentary, precarious eternity is impossible," writes Fackenheim. ${ }^{66}$ Attempts at theodicy as attempts to go beyond the fragmentary nature of the Jewish experience in Midrash thus remains a futile exercise.

Second, Fackenheim notes that Christian theology all too often desires to gloss over the radical horror in the world. Radical horror, he tells us, threatens the radical wonder within religion; and when one abandons the theodicy project, then one must live with the tension between the radical wonder and the radical horror. For Christianity, Fackenheim surmises that radical wonder may be witnessed through the Good News of Jesus. "But after the Holocaust," he writes, "there can be no radical wonder that is not threatened by radical horror; and it is therefore not surprising that most Christian theology today, to protect the wonder, ignores that horror, minimizes it, flattens it out into a universalized horror that is at once everything and nothing., ${ }^{, 67}$ The result of this flattening, however, is an equal and consequential flattening of the Good News - if Christianity flattens the horror, then the wonder becomes flattened as well. Thus, in order to protect the wonder, to maintain a religious awe in the Good News of Jesus and to

\footnotetext{
${ }^{66}$ Ibid., 330.

${ }^{67}$ Ibid., 292.
} 
maintain Christianity's integrity, the horror of Auschwitz (and of all other tragic, oppressive events) must be recognized and remembered, rather than minimized. Fackenheim offers this challenge to Christian theology as its own means of "mending" (Tikkun) its thought after Auschwitz and after its own thought gave way to the rupture of the Holocaust. "This Tikkun is the Boden on which Christian theology can undertake the 'destructive recovery' of the Christian Scriptures, of the Christian tradition, of the Christian faith." 68 This "destructive recovery" is precisely the task I will take up in the next and final chapter.

The final Jewish philosopher whose post-Holocaust writing I wish to examine, Emmanuel Levinas, also argues strongly and convincingly against theodicy. However, whereas Fackenheim builds his post-Shoah religious option firmly upon Jewish foundations by means of the Midrashic framework, Levinas relies on an inter-human order in which Judaism may be included. But his inter-human order is not a Jewish modality of faith per se. It can be expressed, rather, as the face to face encounter of the same with the Other. This encounter arouses within one a sense of the infinity or ultimate alterity of the Other and awakens a feeling of one's responsibility for and to the Other. In his article "Useless Suffering," Levinas denies any notion of instrumental suffering: "the least one can say about suffering is that in its own phenomenality, intrinsically, it is useless, 'for nothing,." ${ }^{69}$ Instead, he describes the only useful suffering within the inter-human order as suffering in oneself for the suffering of the Other or as a response to the suffering of the Other; suffering takes on meaning only by becoming "a suffering for the suffering — be it inexorable — of someone else., ${ }^{, 70}$ Such suffering manifests itself as a relation of love, and ties one to the Other.

\footnotetext{
${ }^{68}$ Ibid., 293.

${ }^{69}$ Emmanuel Levinas, "Useless Suffering," trans. Richard Cohen, in The Provocation of Levinas: Rethinking the Other, ed. Robert Bernasconi and David Wood (New York: Routledge, 1988), 157-158.

${ }^{70}$ Ibid., 159.
} 
Levinas, much like Fackenheim, remarks that theodicy in the face of the Holocaust is an absurdity. For him, there exists a gross incompatibility between any theodicy and the amount of suffering experienced in the Holocaust: "The disproportion between suffering and every theodicy was shown at Auschwitz with a glaring, obvious clarity." ${ }^{, 71}$ Moreover, justifying the pain of one's neighbor, the pain of the Other, "is certainly the source of all immorality." 72 Since the collapse of theodicy and as a result of our realizing its untenability, a philosophical problem arises from the useless suffering concerning "the meaning that religiosity and the human morality of goodness can still retain after the end of theodicy.",73 Unlike Fackenheim, Levinas has given up on the God of history, claiming that any reference to the God of history is suspect because the God of history has been used in theology to create theodicies. As opposed to reliance on theodicy, Levinas moves away from the notion of a God of history and toward the inter-human order, which continues its own Sacred History. In the encounter with the Other, one cannot wait for the God of history to perform saving acts, but rather one must respond to the call of the Other. Levinas suggests that this relation between the same and the Other renders maintenance of a theistic image far more difficult, but it also leaves one "spiritually closer than any kind of theodicy." 74

Finally, Levinas adopts Fackenheim's notion of the commanding voice of Auschwitz and makes it universal. He asserts that the commanding voice not only tells Jews that they must endure after the Holocaust, but it commands each individual to realize his or her responsibility in the face of the Other. Within the inter-human order, each person possesses the responsibility of

\footnotetext{
${ }^{71}$ Ibid., 162.

${ }^{72}$ Ibid., 163.

${ }^{73}$ Ibid.

${ }^{74}$ Ibid., 159.
} 
suffering for the Other as a response to the suffering of the Other. This movement is a form of the continuation of Sacred History that Levinas can affirm:

...must not humanity now, in a faith more difficult than ever, in a faith without theodicy, continue Sacred History; a history which now demands even more of the resources of the other person, to its compassion which is a non-useless suffering (or love), which is no longer suffering 'for nothing', and which straightaway has a meaning?

Levinas thus disavows theodicy as grossly incompatible with the suffering of Auschwitz and universalizes the commanding voice of Auschwitz not only as a call to survive, but also as a call to responsibility for the Other.

\section{Christian Theology After the Holocaust}

In To Mend the World, Emil Fackenheim writes of Karl Barth as declaring the Holocaust "the greatest Jewish catastrophe," 75 but failing to question whether or not it might also have been a Christian catastrophe. Barth's statement brings to light the fact that many Christian theologians and church leaders saw the Holocaust merely as something with which Jews and Judaism must deal—not as a "stumbling block" for Christians. Moreover, Fackenheim poignantly writes that "Barth wrote about Jews as though the Holocaust had not happened: for his Christianity it had not happened."76 Others, on the other hand, evinced a deep desire to dramatically rethink Christian theology in light of the Holocaust. These post-Holocaust Christian theologians did (and do) view the events of the Shoah as debilitating for any theology after 1945, and they have attempted to construct Christian theologies that not only take the Holocaust into account, but also aim at preventing the same sort of virulent anti-Semitism and anti-Judaism from seeping back into dominant, mainstream Christian thought. The two Christian theologians I will briefly describe as I close this chapter, Johann Baptist Metz and Clark

\footnotetext{
${ }^{75}$ Originally found in "The Jewish Problem and the Christian Answer," in Against the Stream (London: SMC Press, 1954), 193. Quoted in Fackenheim, To Mend the World, 133.

${ }^{76}$ Fackenheim, To Mend the World, 133.
} 
Williamson, have done just this - they have invoked prohibitions against any theology that they deem untenable in light of the events of Auschwitz.

Metz, a German Catholic theologian and student of Karl Rahner, remarks in his essay “Theology as Theodicy?" that he too slowly became aware of the fact that Auschwitz had created both an historical and a theological rupture. As he came to this realization, he began to regard the phrase "After Auschwitz" as signifying a "fissure in [his] Christian and theological biography." ${ }^{, 77}$ His own theological career must be altered, he realized, as a result of the postHolocaust situation. Metz describes in this essay exactly how profound and complete the reexamination of Christianity must be after Auschwitz: "Since [realizing the personal and theological rupture of Auschwitz] my theological work has been defined by the insight that in view of Auschwitz we need to examine not only our Christian theologizing about Judaism, but also examine Christian theology—our Christian discourse about God—as a whole." ${ }^{\text {78 }}$ In an effort to reexamine Christian God-discourse in light of the events of the Holocuast, Metz writes that he has returned to questions of theodicy in theology, yet the theodicy he describes is in fact more akin to the anti-theodicies or positions staked against theodicy in the Jewish philosophers mentioned above. He flatly denies the desire to justify God in the face of evil and suffering. Instead, for Metz, "What is really at stake is the question of how one is to speak about God at all in the face of the abysmal histories of suffering in the world, in [God's] world." ${ }^{, 79}$ Understanding how one can theologize or speak about God after Auschwitz becomes the question for theology, and he names this question an eschatological question, since it is a question for which theology does not and cannot determine its own answers. Rather, the questions must be directed back

\footnotetext{
${ }^{77}$ Johann Baptist Metz, "Theology as Theodicy?" in A Passion for God: The Mystical-Political Dimension of Christianity, ed. and trans. J. Matthew Ashley (New York: Paulist Press, 1998), 54.

${ }^{78}$ Ibid., 55 .

${ }^{79}$ Ibid., 56.
} 
toward God. In this sense, Metz does not chase after answers or justifications for God's goodness in light of the gross suffering and evil in the world, but he poses questions to God from out of the darkness of human suffering.

Metz's articulation of theology as a theodicy that refuses justification or explanation seems to heed Fackenheim's entreaties that Christian theology not gloss over the horror in life in favor of the wonder. In this essay and elsewhere, Metz refuses to forget the suffering of Auschwitz and spurns Christianity's unconscious (and sometimes dangerously conscious) desires to let the cries of pain and the harsh questions pointed toward God slip away. Instead of flattening the horror, Metz states:

Christians are only engaging in Christology after Auschwitz when they do not make inaudible to their Christianity those 'cries that faded away so long ago.' Only then are they reading the horrifying record of our history with the eyes of faith, without sneaking past the epicenter of the earthquake in faith's history. ${ }^{80}$

Only by remembering the events of Auschwitz can Christians continue to do theology with any integrity after the Holocaust. Elsewhere Metz formulates this statement as a pointed injunction: "Ask yourselves if the theology you are learning [and constructing] is such that it could remain unchanged before and after Auschwitz. If this is the case, be on your guard." ${ }^{81}$ Metz does not intend that every theology prior to Auschwitz be abandoned, but he does warn against continuing to construct theology in a vacuum, outside the realization and remembrance of the events of the Shoah. Theology that does not remember ultimately appears "empty and blind." 82 In a second article on "The Church After Auschwitz," Metz quotes Elie Wiesel, who describes Christians after the Holocaust with the following: "Yesterday it went: Auschwitz?

\footnotetext{
${ }^{80}$ Ibid., 71.

${ }^{81}$ Johann Baptist Metz, The Emergent Church, trans. Peter Mann (New York: Crossroad, 1981), 29. Quoted in Clark M. Williamson, A Guest in the House of Israel: Post-Holocaust Church Theology (Louisville, KY: Westminster/John Knox Press, 1993), 4.

${ }^{82}$ Metz, "Theology as Theodicy?" 54.
} 
Never heard of it. Today: Auschwitz. Oh yes, I already know about that." His point is not that Christians today are familiar with the Holocaust, but that Christians today appear to believe they have already overcome the Holocaust. Metz, like Wiesel, contends that this should not be the case, affirming something closer to Fackenheim's insistence that there can be no overcoming of Auschwitz. He questions in this article and elsewhere in his theological writings the degree to which the Christian church has reevaluated its own conception of God and its own ability to make faith statements after the Holocaust, asking "Has the memory of Auschwitz transformed us in our existence as Christians?...As Christian theologians do we speak the same way today we spoke yesterday, before Auschwitz?" ${ }^{83}$ Metz does not intend to instrumentalize the Holocaust, such that it serves as a positive moment in the life of Christian theology enabling Christian theology to move away from its more anti-Judaic past. Rather, he views the Holocaust as an historical rupture after which Christian theology cannot and must not continue to follow its old patterns.

Contemporary Christian theologian Clark Williamson likewise recognizes the need to radically rethink Christian theology in the wake of the debilitating events of Auschwitz. Williamson, a student of both Tillich and the Chicago process tradition, draws from traditional liberal Christian theology and from process philosophy as he develops a Christian theology for the church that aims at being appropriate to Judaism. In his text Way of Blessing, Way of Life, Williamson's systematic theology, he begins by calling attention to the fact that centuries of Christian theology has served to denigrate Judaism, ultimately resulting in the anti-Jewish and even anti-Semitic impulses that led to pogroms, ghettoes, and the Shoah. Williamson calls for Christianity to ends its "death-dealing" anti-Jewish and anti-Semitic tendencies, and he

\footnotetext{
${ }^{83}$ Johann Baptist Metz, "The Church After Auschwitz" in A Passion for God: The Mystical-Political Dimension of Christianity, ed. and trans. J. Matthew Ashley (New York: Paulist Press, 1998), 124.
} 
contributes to positive versions of Christian theology by systematically constructing theological statements that remain appropriate to Judaism in the post-Shoah situation. He does not simply adopt Jewish modes of theology or philosophy, but maintains a distinctly Christian theology that is informed by Judaism and that avoids making any statement against Judaism. In fact, the hallmark of his work is his development of what he terms a "norm of appropriateness" for Christian theology. This norm arises in the context of biblical interpretation, yet it applies equally to the theological frameworks in which Williamson works. His norm of appropriateness may be read as follows: "the promise of God lovingly offered to each and all, and the command of God that justice be done to each and all..." 84 Such a norm strives, I argue, to maintain the wonder of the Gospel alongside the horror of life. It recognizes the promise as well as the command; it sees the Good News, but also gives articulation to the imperative that Christianity should no longer permit theological statements that denigrate Judaism.

Both Metz and Williamson demonstrate the fact that Christian theology must radically reexamine its own statements and its own long-held assumptions in light of the Holocaust. Auschwitz may no longer be viewed as something with which only Judaism must deal; rather, Christianity too must reconceive its own theology in light of the events of Auschwitz in order to resist overcoming or mastering the past and in order to rightly remember the deleterious events to which it (in part) contributed.

Beyond these direct implications from previous Christian post-Holocaust theologies, there are a number of trajectories and insights arising from the various theological strands of Adorno, Voegelin, Fackenheim and Levinas that will be woven into the emerging theology of remembrance that this work aims at unfolding. Perhaps paradoxically, both Adorno's critique of

\footnotetext{
${ }^{84}$ Clark M. Williamson, Way of Blessing, Way of Life: A Christian Theology (St. Louis, MO: Chalice Press, 1999),
} 82. 
appeals to transcendence and Voegelin's notion of humanity as grounded in transcendence add their own unique and important insights to this theology, each mediated by Whitehead's notion of the dipolar God, as I will outline in the following chapter. The strong critiques of theodicy voiced by Fackenheim and Levinas echo Faber's critiques of theodicy from a Whiteheadian perspective in previous chapters, and they remind us that attempts at theodicy easily become endeavors at mastering the past. As a result, the theology of remembrance that I construct here does not aim at giving explanations of evil alongside God's goodness and omnitpotence. Rather, the theology presented here affirms Whitehead's dipolar God who acts in the world according to persuasive power and love, as opposed to coercive measures, and, therefore, I am not interested in defending positions of omnipotence but am ultimately much more drawn to Loomer's theology of God as ambiguous (as a result of the world's ultimate and actual ambiguity). Finally and most importantly, the next (and final) chapter will pick up Adorno's notion of inverse theology, tracing it through the work of Walter Benjamin in order to provide theoretical and critical insights into what historical materialism offers a post-Holocaust Christian theology of remembrance. 


\section{Chapter 8: A Christian Theology of Remembrance}

In the preceding chapters I have shown how Whitehead's metaphysical system takes the entire content of the past into account, without ignoring the deleterious components of the past. Likewise, any theology of remembrance building upon a conversation among Adorno, Voegelin and Whitehead also must take seriously the whole mass of past experience, both joyful and debilitating. We have seen also the tension noted by Faber between the past and future, out of which novel possibilities for the present emerge. This tension, taken together with thoughts arising from Adorno and Voegelin results in what I describe as a theology of remembrance- $a$ Christian theology that retains the tragic, the incomprehensible suffering of the Shoah, and rethinks our understanding of God in light of the past events of the Holocaust in a way that few previous Christian theologians have adequately done. In formulating such a theology, I look to three thinkers at the outset of this chapter who have previously articulated theologies or philosophies of remembrance. Noted Christian theologian Miroslav Volf has written extensively on the problem of coming to terms with harmful aspects of the past and describes his own theology of remembrance in The End of Memory. Johann Baptist Metz, with whom we engaged in the previous chapter regarding post-Holocaust Christian theology, offers a series of statements regarding memory and the Holocaust in his articles "Theology as Theodicy?" and "The Church After Auschwitz." Finally, Jewish philosopher, literary critic and historical materialist Walter Benjamin provides a number of fragments in the form of theses on the philosophy of history, not unlike the Midrashic fragments described by Fackenheim, that uncover the necessity of remembering the past as a means of redemption. In what follows I will work through the various theologies/philosophies of remembrance each thinker unfolds before returning to Whitehead, Adorno, and Voegelin as I cast my own vision for a Christian theology of remembrance that 
resists overcoming the past and focuses instead upon mastering the present. Undoubtedly and admittedly, the theology presented here affirms Whitehead's notion of God as dipolar and as chief exemplification of his speculative scheme. This theology also unabashedly calls itself a materialist theology, by which I mean that it accepts and adopts a historical materialist critique of reification, economic modes of production, and notions of history divorced from the material conditions of those who find themselves tossed about on and wrecked by the waves of overarching historical narratives, Capitalistic desires, and nationalistic fury. I find Whitehead to be a surprisingly helpful thinker as I delve into historical materialist thinking because, as mentioned earlier with respect to the Idealist-Empiricist divide, I locate Whitehead more on the side of the materialists than on the side of the Idealists. Similar to the way in which I describe Whitehead as located on the side of the empiricists, I suggest that Whitehead, like the materialists, begins his speculative philosophy from the concrete events of the actual world. Though he does seek to coordinate actual occasions within a system of general ideas (which I have read as expressing some similarity to Benjamin's notion of the constellation, picked up by Adorno), his alliance remains to the actual. There is "no going behind actual entities to find anything more real." For the materialists, there is no going behind the history of material processes within the world to claim something real beyond the material. The historical materialist critique of Capitalism understands this third mode of production as an abstraction, as reifying a concept into an explanation of reality behind or beyond the relations immanent within the actual, material world. Both Whitehead and the materialists critique such reliance on abstraction rather than on the material, the actual entities that constitute the world. ${ }^{2}$

\footnotetext{
${ }^{1}$ Whitehead, Process and Reality, 18.

${ }^{2}$ Michael Halewood, A. N. Whitehead and Social Theory: Tracing a Culture of Thought (New York: Anthem Press, 2011), 149.
} 
This theology of remembrance contributes to the field of post-Holocaust theology by conceptualizing how theology can and must consider the past even as it looks forward into the future. It retains a prescriptive and critical role, as it describes a more helpful lens through which to understand and reflect upon the frightful events of one's own past, of one's own Christian past, and marks a path toward a future that incorporates a norm of remembrance.

\section{Volf's Theology of Remembrance}

In The End of Memory: Remembering Rightly in a Violent World, Christian theologian Miroslav Volf offers his own theology of remembrance based on his experience as a military prisoner in former Yugoslavia. Considered to be an "enemy of the state" for his religious views and his marriage to an American woman, Volf was imprisoned and interrogated by the military in which he was serving (as a part of his compulsory service). In the book, Volf recounts the torture involved in his imprisonment when Captain G. (the pseudonym he gives to the commanding officer who conducted his interrogations) attempted to extract information from him that did not, in actuality, exist. Volf contends that in response to the catastrophes of the twentieth century (including the genocides of the Holocaust, Rwanda, the ethnic cleansing in the former Yugoslavia) "that it is important not merely to remember, but also to remember rightly.",3 He argues that remembering the atrocities of the past "is to struggle against" that past in order to create possibilities for a less deleterious future. By remembering rightly Volf intends that memory of the past not result in retribution, but in a communal remembrance that embraces the suffering of the past and longs for a future in which the causes of suffering may be eliminated. Remembering rightly also involves truthful remembering, which includes recalling the events of

\footnotetext{
${ }^{3}$ Miroslav Volf, The End of Memory: Remembering Rightly in a Violent World (Grand Rapids, MI: William B. Eerdmans Publishing, 2006), 10.
} 
the past in order to uncover and subvert the totalizing power of those who committed harmful and oppressive acts.

Volf's theology of remembrance does not seek to simply recount the events of the past as an exercise of assigning blame or assessing guilt (the act against which Voegelin warns), but rather he seeks to uncover and remember the very impetus behind the deleterious events in order to master the present. Moreover, Volf understands remembrance as operating outside of linear conceptions of time, such that "[w]hen we remember the past, it is not only past; it breaks into the present and gains a new lease on life." 4 In this sense, Volf's theology aligns well with both a Voegelinian and Whiteheadian understanding of the past. The past cannot be overcome inasmuch as it is past; however, remembrance rightly creates the conditions for the possibility of mastering the present. "It is true that we must recall past wrongs in order to struggle against present ones," writes Volf. ${ }^{5}$ Remembrance of past suffering does not necessarily lead in and of itself to positive possibilities for the future, but without remembrance of the past, we run a greater risk of returning to the destructive patterns that engendered such suffering in the first place. Additionally, conscious remembrance means that the past lives on in the present and future not as an all-consuming burden, but as a caution against repetition of previous wrongs and as an assurance that baleful events will not be overcome or effaced. Clearly these words must be addressed to the perpetrators of past wrongs, or to those who stood idly by, and not to the victims, since the onus lies with those complicit in the wrongs of the past to ensure that they not be repeated. In the case of post-Holocaust Christian theology, present and future Christian theologians carry the burden of guarding against statements that are not tenable in light of the events of Auschwitz.

\footnotetext{
${ }^{4}$ Ibid., 21.

${ }^{5}$ Ibid., 31.
} 
Another significant aspect of Volf's theology of remembrance, and one which I am disinclined to follow, arises in part from an earlier work in which he describes the process of forgiveness for wrongs committed in the past. In Exclusion and Embrace, Volf outlines a means of reconciliation with those others who have caused harm to individuals and communities. This book was written largely as a response to a question raised by German theologian (and Volf's graduate school mentor) Jürgen Moltmann at a conference at which Volf called for Christians to embrace their "others." Included in the category of "other" are those who have wronged a person in the past_one's enemies. Moltmann asked Volf directly if he could, as a Croatian, embrace a cetnik, the term for Serbian fighters in the former Yugoslavia who decimated entire towns of Croatians by either brutally murdering them or herding them into concentration camps. Exclusion and Embrace is Volf's way of answering Moltmann's question affirmatively. Yes, he must be able to embrace a cetnik. ${ }^{6}$ His subsequent conversation in the book, which is picked up in the second half of The End of Memory, centers around forgiving and forgetting the wrongs committed against us. In The End of Memory, he writes of remembrance as redemption because remembering the past means that the harmful past "must and will be redeemed," and he sees this as a central and essential component of Christianity. ${ }^{7}$ Furthermore, Volf encourages those who carry debilitating memories of the past to "integrate" events into their life stories "by giving them positive meaning. ${ }^{8}$ While he acknowledges the incomprehensibility of horrendous past suffering, he suggests that such events still be integrated by labeling them as "senseless segments of our life-story." "9 Having spent the better part of a chapter deconstructing any terminology in Whitehead that hints at integration of the past, and having detailed Voegelin's injunctions against

\footnotetext{
${ }^{6}$ Mark Oppenheimer, "Miroslav Volf Spans Conflicting Worlds," in The Christian Century January 11, 2003: 1823.

${ }^{7}$ Volf, 42 .

${ }^{8}$ Ibid., 76 .

${ }^{9}$ Ibid., 77.
} 
mastering the past (which I think that Volf has heretofore heeded), the theology of remembrance advocated here cannot go along with Volf's form of redemption as integration, since he seems to want to endow deleterious events with positive meaning in the overarching stories of an individual's or a community's life. Fortunately, Volf back pedals slightly when he arrives at a discussion of the Holocaust. He helpfully notes that "the Holocaust experience resists being tamed by the imposition of meaning; for the most part, the experience appears impossible to integrate into a larger narrative of meaningful life." ${ }^{\prime 10}$ Nevertheless, after examining examples of salvation that do not attempt to provide meaning to horrific events, Volf concludes that if those who experienced debilitating suffering such as that at Auschwitz "are to find redemption, they will need to experience" the kind of salvation in which pain and suffering are "not taken up into a meaningful unity but swallowed up by Christ..."11 This kind of redemption may not focus on integration and "harmonizing," but it does include, writes Volf, "driving out" and "overcoming," such that finally "God does not take away our past; God gives it back to us - fragments gathered, stories reconfigured, selves truly redeemed, people forever reconciled." ${ }^{\text {"12 }}$ Volf's redemption comes in the form of Christ crucified, by which Christ serves as liberator from the suffering that humans encounter in this world.

Volf's insistence on redemption through Christ, however, reinscribes deleterious events into Christian theology by allowing a means for them to be overcome. If the event(s) is overcome, reconciled, redeemed, or gather together into an overarching narrative, then the need for Christian theology to be on its guard is far less stringent. If such events are ultimately overcome through Christ, then where is the theological norm or imperative that aims against making statements that could lead to or excuse these events? Moreover, seeking a solution to

\footnotetext{
${ }^{10}$ Ibid., 185.

${ }^{11}$ Ibid., 188.

12 Ibid.
} 
suffering in transcendence smacks of a mastery that abandons the harsh reality of this world in favor of a redeemed beyond. In Fackenheim's terms, doesn't Volf finally attempt to maintain the wonder while simultaneously minimalizing or flattening the horror? Volf argues later that nothing of the past is lost by means of this redemption, but rather "God does not take away our past; God gives it back to us - fragments gathered, stories reconfigured, selves truly redeemed, people forever reconciled."13 Yet effacement or loss of the past is not the only act against which the injunction to master the present (and not the past) struggles. It also struggles against forms of overcoming or mastery that attempt to gather fragments into a cohesive narrative, into a story that abandons contradiction in favor of overarching narrative. As Voegelin has shown us, overarching narratives that gloss over the details of events prove all-too-often to be nothing more than a cliché. And aren't such narratives the very problematic form of historicism against which the various thinkers included in this work argue? I will return to Volf's use of the crucifixion and resurrection in my own constructive work below where I counter Volf's assertions with a different (and perhaps materialist) understanding of the crucifixion and resurrection by way of Peter Rollins.

\section{Metz on Memory After Auschwitz}

Unlike Volf, Metz has not developed a theology of remembrance, although he does provide several important and helpful thoughts on the process of remembering and the significance of memory after the Holocaust. In "Theology as Theodicy?" Metz questions the Greek and Jewish influences on early Christianity as he looks for the source of the Spirit as it developed in early Christian thought. He determines that early Christianity swayed too far in the direction of Greek philosophy when developing its notion of Spirit, and as a result "[w]hat is at

\footnotetext{
${ }^{13}$ Ibid., 201.
} 
issue here — something that has been obstinately concealed in traditional Christian theology—is thought as memory, as historical remembrancing [geschichtliches Eingedenken]. ${ }^{.14} \mathrm{Had}$ Christianity adopted what he sees as "the Jewish spirit as the power of memory," Metz suggests, Christianity's ability to remember may not be so atrophied. "Jewish memory resists forgetfulness, even the forgetfulness of the forgotten." Yet as Metz reports, "[t]his Jewish culture of remembering is lacking both in European Christianity and in the European spirit as a whole." 15 He suggests that "remembrancing" might help Christian theology overcome its tendency toward two types of forgetfulness: first, a forgetfulness that effaces the past, and second, the forgetfulness evidenced in historicism as an operation that separates us from our past. To counteract such forgetfulness, remembrance "which is always on the trail of forgetfulness...would really be the organ of a theology which, as theodicy, tries to confront our most progressive consciousness with what has been forgotten in it: the grievances and complaints of the past." ${ }^{\prime 16}$ The theodicy to which Metz hints here, as we recall, is not the type of theodicy that seeks a systematized explanation of God's goodness in the face of evil. Metz does not attempt to reconcile evil or explain evil; on the contrary, what he means by theology as theodicy is a type of theology that refuses to abandon the horrific suffering of human beings in favor of some neat and tidy picture of God. In this sense, his theology as theodicy calls for remembrance as a corrective measure to guard against the tendency to leave the harmful past behind. Metz closes his essay on "The Church After Auschwitz" with a quote from Elie Wiesel spoken at Wannsee, the location in which the "Final Solution" was first conceived. Wiesel writes:

\footnotetext{
${ }^{14}$ Metz, "Theology as Theodicy?" 64.

${ }^{15}$ Metz, "The Church After Auschwitz," 130-131.

${ }^{16}$ Metz, "Theology as Theodicy?" 65.
} 
But Wannsee also means for us Jews that memory is stronger than its foes. It means that the hope of the Jews has triumphed over their fear. It means that coming back to Wannsee and listening to the hard, dark echoes of those voices, we Jews want to save coming generations from having our past become their inheritance for the future. ${ }^{17}$

Metz then concludes that this memory, invoked in order to save future generations from experiencing the suffering of the past, must also be a message for the church insofar as the church has the power to resist replaying its own anti-Jewish and anti-Semitic past. His conclusion affirms the inclusion of a theological norm that aims at keeping both the church and the Christian academy from formulating statements that play into the hands of anti-Jewish or anti-Semitic positions.

\section{Benjamin's Weak Messianism and Inverse Theology}

Finally, I wish return to the notion of inverse theology introduced by Adorno in his correspondence with Walter Benjamin. Tracing this concept further through the philosophicalhistorical writings of Benjamin allows one to see the connection he makes between the past and redemption. For Benjamin, redemption becomes historical remembrance of the victims of the past, and such redemption occurs not in some future time or some future beyond time, but in the present. Redemption through remembrance arises through what he refers to as the "weak Messianic power" with which humanity is endowed. ${ }^{18}$ Therefore, similar to Voegelin, Benjamin's view of redemption manifests itself as a necessary mastery of the present; and similar to Whitehead, redemption can more adequately be named as maintaining the past, rather than a sublation of the past into an eternal concept outside of history. Benjamin's work in the "Theses on the Philosophy of History" also invokes the notion of inverse theology mentioned

\footnotetext{
${ }^{17}$ Metz, "The Church After Auschwitz," 132.

${ }^{18}$ Walter Benjamin, "Theses on the Philosophy of History," in Illuminations, ed. Hannah Arendt (New York: Schocken Books, 1968), 254.
} 
above_ “"a photograph of our earthly life from the perspective of a redeemed life..."19 This view of "damaged life" from the perspective of the redeemed enables us to work upon the present, remembering the deleterious events of history, without seeking to overcome the past. Like Adorno's inverse theology and his assertions in “Reason and Revelation," Benjamin's theological reflections in "Theologico-Politcal Fragment" and "Theses on the Philosophy of History" point toward an understanding of redemption that refuses to betray the suffering of damaged life in favor of a redeemed beyond. I will first examine the "Theologico-Political Fragment," before turning to a consideration of the "Theses."

The "Fragment," written in 1920-21, conveys an anti-teleological and anti-immanentist Messianic vision in which nothing historical can relate to the Messianic on its own terms. In this sense, in the order of the profane, there can be no approach to the Messianic as a goal; rather, the profane moves in a direction contrary to the Messianic. However, Benjamin writes: "just as a force can, through acting, increase another that is acting in the opposite direction, so the order of the profane assists, through being profane, the coming of the Messianic Kingdom." ${ }^{20}$ Neither religious nor political endeavors should seek to establish such a kingdom, since the material world in fact moves in opposition to the Messianic. No worldly institution can grasp the Messianic, and in fact the world realizes its downfall in the attempt to do so. But at the same time this downfall itself, the eternal passing away of the world, gives rise to the "quietest approach" of the Messianic. One should not strive after hastening the Messiah by increasing the trajectory of the profane, since, as Benjamin quips, world politics already does this of its own accord. Neither is the goal to transcend this world in order to arrive at the Kingdom of God. Instead, one must recognize that the Messiah comes only at the end of a long history of suffering

\footnotetext{
${ }_{19}$ Adorno and Benjamin, The Complete Correspondence, 66.

${ }^{20}$ Walter Benjamin, "Theologico-Political Fragment," in Reflections, ed. Peter Demetz (Schocken Books, New York: 1978), 312.
} 
that is the eternal and total passing away. In this manner, arriving at the Messianic requires one to "pass through misfortune, as suffering." 21 There is no circumvention of the suffering of damaged life in favor of easy access to the redeemed.

To understand what Benjamin means by the Messianic, we turn next to his "Theses on the Philosophy of History," written very near the end of his tragically abbreviated life. The theses theologize materialism or, more accurately, introduce theology into the service of historical materialism, as Benjamin describes in the first thesis. He writes in thesis II that humanity is endowed with a "weak messianic power," to which the past has a claim; it has a claim in that the past requires redemption through this weak messianic power by means of remembrance, by requiring that the past not be lost through the rush of progress or the impulse to forget. Thus, the weak messianism carries the past, the foregone suffering of damaged life, into the future, and this act of remembrance, for Benjamin, denotes the process of redemption. Here I follow Michael Löwy's reading of the Theses, which argues that Benjamin does not expect a Messiah to come to earth from heaven, but rather he understands humans as endowed with this “weak Messianic power" which, when combined among oppressed humans, can aid in redeeming the suffering and oppression of past generations. The Messianic in Benjamin directs itself not only to the past, but also the present and future in which redemption becomes a distinct possibility through the revolutionary task of emancipating the oppressed. As Löwy writes, Benjamin's redemption is "not mere restitution of the past, but also active transformation of the present." 22 It does not merely recognize the suffering of damaged life, but it aims at action that ceases the suffering.

\footnotetext{
${ }^{21}$ Ibid., 313.

${ }^{22}$ Michael Löwy, Fire Alarm: Reading Walter Benjamin's 'On the Concept of History', trans. Chris Turner (New York: Verso, 2005), 34.
} 
A close reading of the second thesis (in conjunction with the Theses as a whole-if one can refer to a collection of fragments as a whole) betrays further, though still in nearly inscrutable ways, what Benjamin means by the weak Messianic power. He begins the thesis by quoting Lotze, the largely forgotten German Idealist, as saying that the present cannot be envious of the future, but only the past. This is the case because the future remains unknown. How can one be envious of what one does not know? The past, however, has happened and is, to some degree or another, known; hence, one can be reflect on or remember the past and be envious of a happiness that went unrealized in one's own past. In Benjamin's words: “The kind of happiness that could arouse envy in us exists only in the air we have breathed, among people we could have talked to, women who could have given themselves to us." 23 He then binds the notion of happiness with the notion of redemption and applies it to the past such that instead of looking back on the happiness that could have been but, alas, was not, we look back on the redemption that was not-we look back on the unredeemed generations preceding us, those who have suffered in the past. If, as Benjamin writes, the "past carries with it a temporal index by which it is referred to redemption," 24 then redemption is not just something for the present and future, but is also something for the past—-the past has a claim upon the weak messianic power that brings redemption through remembrance. This weak messianic power is, according to Benjamin, endowed within each generation, including the present generation, whose "coming was expected on earth." ${ }^{25}$ Hence, like the Messianic mentioned in the "Theologico-Political Fragment," the weak messianic power comes from the future in order to redeem the past. ${ }^{26}$ It arrives, relative to

\footnotetext{
${ }^{23}$ Benjamin, "Theses on the Philosophy of History," 254.

24 Ibid.

25 Ibid.

${ }^{26}$ Roland Faber, The Divine Manifold, chapter 9.
} 
past generations, in the form of future generations and orients itself to the task of redeeming the unredeemed of the past through the operative power of remembrance.

Michael Löwy reads Benjamin’s weak messianism in fiery, revolutionary terms as a means by which we use our own limited power to spark revolutionary moments that redeem the past through actions in the present oriented toward diminishing the suffering of the oppressed. I read Benjamin's weak messianism in less fiery terms than Löwy, but perhaps in no less radical terms. In the midst of hopelessness, we are the only hope. The past has a claim upon us by means of the mandate to remember the suffering of foregone generations, including (most significantly for this post-Holocaust theology) the suffering of the victims of Auschwitz. By means of this remembrance via our own weak messianic power, the past might be redeemed. To be sure, Benjamin does not see this redemption as overcoming the suffering of the past or as endowing the past with positive meaning. Rather, redemption through remembrance holds open the possibility, absurd as it may be, that suffering in the present and future might be diminished as a result of our remembrance of the victims of the past through our weak messianic power. Insofar as the messianic comes into the present as something for the past from the future, the potentiality of the future and the potentiality within God as locus of future possibility in Whitehead lend force to Benjamin's conception of weak messianism. The future really is (metaphysically, for Whitehead) something for the past, and most importantly, the future cannot overcome, leave behind, or efface the past if the future is itself oriented toward redeeming the past through remembrance.

I maintain that Benjamin's writing in the Theses exemplifies the notion of inverse theology, which Adorno described already six years prior to the Theses, because it assumes a gaze toward damaged life from the perspective of the redeemed through the lens of the weak 
Messianic power with which Benjamin insists humans (or at least oppressed humans) are endowed. The act of peering through the lens makes apparent the necessity of redemption through remembrance. Just as inverse theology for Adorno becomes a prolegomenon to an uncertain but hoped for transformation of material life, Benjamin looks forward toward transformation of the present through revolutionary action. Throughout the Theses, Benjamin, like Adorno, contends that focus must remain upon the suffering of damaged life, without seeking the divine or the Messianic through a turn to the transcendent. Nowhere is this more poignantly present than in Thesis IX in which Benjamin refers to Paul Klee's Angelus Novus, writing, "This is how one pictures the angel of history. His face is turned toward the past. Where we perceive a chain of events, he sees one single catastrophe which keeps piling wreckage upon wreckage and hurls it in front of his feet." 27 The angel, whose back is turned to the future, has lingered with its gaze upon the ever-increasing pile of wreckage in the past and is now caught in the storm of progress, pushed backward into the future, so to speak. Löwy suggests that "The Angel of History would like to halt, to bind the wounds of the victims crushed beneath the pile of ruins, but the storm carries it on inexorably towards the repetition of the past: to new catastrophes, new hecatombs, ever vaster and more destructive."28 The angel of history appears powerless against the onslaught of suffering that damaged life unfolds. In the Theses only the Messianic, by means of humanity's own weak Messianic power, proves to be a match for the oppressive and destructive conditions of material reality, and hence only by maintaining one's gaze on earthly, damaged life through the lens of the weak Messianic power and from the perspective of the redeemed can one hope to change material reality from a history of suffering and oppression to a less oppressive future.

\footnotetext{
${ }^{27}$ Benjamin, "Theses on the Philosophy of History," 257.

${ }^{28}$ Löwy, 64.
} 
Benjamin argues explicitly in the Theses for an understanding of theology as operating in the service of historical materialism. In Thesis I he describes an automaton of a puppet and a hidden hunchback, which together can play a winning game of chess. The hunchback, hidden beneath the table and concealed by a series of mirrors, controls the puppet, enabling it to successfully play and win games of chess against opponents. ${ }^{29}$ He likens the puppet to historical materialism and the hunchback or dwarf to theology, insisting: "The puppet called 'historical materialism' is to win all the time. It can easily be a match for anyone if it enlists the services of theology, which today, as we know, is wizened and has to keep out of sight." ${ }^{, 30}$ Only by enlisting the aid of theology can historical materialism win, according to Benjamin; otherwise it remains a mere puppet without an enlivening agent. Theology thus serves as an aid to historical materialism, which in Benjamin's view had, in the hands of Marxist interpreters of his own age, become a mere machine inevitably leading to the triumph of socialism. Theology, on the other hand, denuded of its former power as an agent in the lives of human beings, had to operate undercover or out of sight after the rationalist Enlightenment influence took hold. Benjamin now attempts to restore historical materialism to its true theoretical position, not as a foregone conclusion, but as a critical stance against oppressive conditions in material reality, by appealing to the vivifying effects of theology. Löwy tells us, "Theology for Benjamin is not a goal in itself; its aim is not the ineffable contemplation of eternal verities, nor, even less, reflection on the nature of the divine Being...it is in the service of the struggle of the oppressed." ${ }^{31}$ In this regard, Benjamin simultaneously resists employing either a pre-Enlightenment theology or what Adorno would later refer to as revealed religion. Instead, the theological position enlisted here

\footnotetext{
${ }^{29}$ Benjamin takes the image of the chess-playing automaton from a literary source. The image first appears in Edgar Allen Poe's short story "Maelzel's Chess Player," encountered by Benjamin mostly likely in Baudelaire's French translation of the story.

${ }^{30}$ Benjamin, "Theses on the Philosophy of History," 253.

${ }^{31}$ Löwy, 27-28.
} 
should, in my view, be described as inverse theology —a theology focused on damaged life and on possibilities for "redemption" (in Benjamin's terms) within the material world.

I should be clear to note that my interpretation of Benjamin's first thesis follows Michael Löwy's interpretation; however, this is not the dominant interpretation among Benjamin scholars. Jay Geller, most notably, disagrees with Löwy's reading, arguing instead that the hunchback hidden inside the automaton is not a helpful character, but a haunting, controlling character. ${ }^{32}$ He makes this argument through reference to another hunchback mentioned by Benjamin in his essay on Kafka. "The Little Hunchback" was a well-known folk song sung by German children. The folk song was tied in Benjamin's memory to his mother's quip that when some mishap occurred during his childhood it must have been the fault of the hunchback.

Taking on the characteristics of a distorted reality, the hunchback appears to children in unusual times, such as during prayer time or when the child is alone in his or her room. Geller believes that Benjamin's reference to the dwarf inside the automaton as a hunchback is no coincidence, but actually demonstrates that Benjamin assesses theology negatively as a controlling apparatus, pulling the strings and forcing its claims onto historical materialism. Löwy disagrees with this interpretation (as do I), and argues instead that the puppet itself, historical materialism, could not have won the game of chess without the dwarf. Instead of adopting a negative view of theology, as Geller suggests, Löwy insists that Benjamin finds theology quite useful. If he hadn't, then he likely wouldn't have made such clear use of it in the theses that followed. Löwy continues to play with the analogy of theology as the dwarf that is wizened and has to keep out of sight. He recites a line from Benjamin's "Paralipomena" to the theses: "My thinking is related to theology as blotting pad is related to ink. It is saturated with it. Were one to go by the blotter, however,

\footnotetext{
${ }^{32}$ Jay Geller's interpretation was mentioned during his response to my paper on Adorno and Benjamin's inverse theology at a panel on the Frankfurt School and Religion at the American Academy of Religion annual meeting, November 21, 2011.
} 
nothing of what is written would remain." 33 The presence of theology in Benjamin's thought is significant and cannot be overlooked; nor can it be seen as a controlling, distorted mechanism that disrupts all thought. Rather, theology plays a vital role in Benjamin's work despite the fact that it is frequently hidden or concealed within other motifs. Moreover, Löwy clearly refutes Geller's claim by reminding the reader of the reversed positions of the puppet and the dwarf. At first the dwarf seems to be controlling the puppet, yet Benjamin writes at the end of the first thesis that the dwarf (theology) is "in the service of" the puppet (historical materialism). This does not denote a relationship of mastery or control, but one of assistance and support. To repeat Löwy's definition of theology as it appears in the work of Benjamin: "Theology for Benjamin is not a goal in itself... it is in the service of the struggle of the oppressed."34

The first paragraph of Slavoj Zizek's The Puppet and the Dwarf introduces a reversal of Benjamin's call for theology to be in the service of historical materialism. Zizek's writes:

Today, when the historical materialist analysis is receding, practiced as it were under cover, rarely called by its proper name, while the theological dimension is given a new lease on life in the guise of the 'postsecular' Messianic turn of deconstruction, the time has come to reverse Walter Benjamin's first thesis on the philosophy of history... ${ }^{35}$

He takes the reversal of the thesis in a decidedly Christian direction, suggesting that in order to be a good Christian one must first be a good materialist, and thus historical materialism must now be in the service of theology, since historical materialism (Zizek argues) is itself now wizened and out of sight. I disagree with Zizek in two regards. First, I doubt very highly that theology has attained the position in which he seems to view it. Perhaps theology has been given a new lease on life in certain continental philosophical circles through Derrida's return to religion toward the end of his life; however, in North America we remain haunted by the three

\footnotetext{
${ }^{33}$ Löwy, 27.

${ }^{34}$ Löwy, 27-28. Emphasis added.

${ }^{35}$ Slavoj Zizek, The Puppet and the Dwarf: The Perverse Core of Christianity (Cambridge, MA: The MIT Press, 2003), 3 .
} 
specters of scientific fundamentalism—Daniel Dennet, Christopher Hitchens, and Richard Dawkins - as well as by our own onto-theological past, which continues to dwell prominently in the memories of those most injured by its totalizing claims. As a result, theology remains more a suspect field than a noble enterprise in the eyes of the majority. Second, Zizek suggests, on the surface, that historical materialism can aid Christian theology in order for theology to "win" by saying that in order to be a good Christian one must first be a good materialist. However, I wonder if what Zizek really wishes to argue is more akin to Jay Geller's interpretation of the first thesis, namely that the dwarf actually usurps control of the puppet, in which case Zizek would actually be suggesting (however subtly) that Christian theology should give way to historical materialism. ${ }^{36}$ Zizek has already undertaken such usurpations with regard to Judaism, ${ }^{37}$ and now he places Christianity in a position to be usurped by historical materialism. This view does not support my reading of Benjamin's Thesis I, which corresponds with Löwy's reading, that the dwarf is in the service the puppet. But if Zizek's reading of the thesis aligns with Geller's, then one must question what Zizek is actually up to with this reversal.

Returning directly to the Theses, Benjamin also delivers a conception of history that refuses to accept the movement of time as an inevitable progression solely determined by events of the past. Benjamin's description of the opening up of history appears somewhat similar to Whitehead's nonlinear notion of temporality, despite the vast differences in terms of metaphysical technicality (or interest in "doing” metaphysics whatsoever). As Löwy points out, Benjamin's thought does not manifest itself in any sort of philosophical system, though it must

\footnotetext{
${ }^{36}$ Interestingly, Zizek also seems to employ a form of inverse theology when he writes in The Puppet and the Dwarf that the goal is not to seek redemption from the fall, but to recognize salvation in the fall-though of course he doesn't footnote Adorno or Benjamin.

${ }^{37}$ For instance, when he writes at the end of his essay "Neighbors and Other Monsters" that "the 'infinite judgment' is here "Christianity is Judaism." Slavoj Zizek, "Neighbors and Other Monsters," in The Neighbor: Three Inquiries in Political Theology (Chicago: University of Chicago Press, 2005), 190.
} 
still be taken as "a whole, in which art, history, culture, politics, literature and theology are inseparable. ${ }^{38}$ This point serves both to separate his thought from Whitehead and to tie him to a Whiteheadian reading of history. Benjamin does not aim at deriving a metaphysical system, nor does he seem to adopt any pre-existing metaphysics as a helpful means for examining the historical process. Nevertheless, the inextricable links among various realms of thought in Benjamin's work evince a striking similarity to Whitehead's speculative philosophy as an "endeavor to frame a coherent, logical, necessary system of general ideas in terms of which every element of our experience can be interpreted. ${ }^{39}$ Not only are diverse fields inseparable, but thinking within these fields also starts from experience. Inasmuch as Benjamin remained a strong historical materialist throughout his life, his philosophy of history (or theories of art, literature, culture and politics, for that matter) begins with concrete situations of material reality. Thus, material reality must never be left aside in favor of seeking a beyond in which answers or reasons for material existence might be found (since there is no "beyond" for the historical materialist). While historical experience remains tied to theories of production and surplus in terms of which experience can by evaluated, such theories are not outside of lived reality, but are determined by and manifested within the actual world. Reading history as the story of modes of production and uses of surplus enables Benjamin to examine the oppressive structures existent within the material world, and his "Theses on the Philosophy of History" focus on various forms of oppression that emerge as a part of the historical process.

Löwy describes Benjamin's Theses as "a kind of philosophical manifesto, in the form of dialectical images and allegories rather than abstract syllogisms, for the opening-up of history." ${ }^{40}$ By this he means that Benjamin's concept of history maintains openings for novel possibility

\footnotetext{
${ }^{38}$ Löwy, 1.

${ }^{39}$ Whitehead, Process and Reality, 3.

${ }^{40}$ Löwy, 107. Emphasis appears in the original.
} 
within the objective conditions of material existence. Benjamin, like Whitehead, rebuffs the optimism of those who believed history evidenced a linear societal progression toward ever more far-sweeping social improvement, through either economic or technological advances. ${ }^{41}$ Against these views, the Theses display a cautious pessimism, not in a defeatist sense, but in the sense that conditions among the oppressed classes in material reality may not change unless some sort of irruption occurs within reality that inaugurates a revolutionary shift. The revolutionary irruption, in Benjamin's terms, must be fought for or enacted by human powers—one cannot simply wait upon an inevitable revolution, which Benjamin does not think will ever come of its own accord. Keeping open the possibility for this irruption constitutes the primary sense in which Löwy cites an opening-up of history in Benjamin's writings. Löwy writes:

if history is open, if 'the new' is possible, this is because the future is not known in advance; the future is not the ineluctable result of a given historical evolution, the necessary and predictable outcome of the 'natural' laws of social transformation, the inevitable fruit of economic, technical or scientific progress-or, worse still, the continuation, in ever more perfected forms, of the same, of what already exists, of actually existing modernity, of the current economic and social structures. ${ }^{42}$

In 1940 Benjamin was responding to a very real situation in which a stronghold within the Western world thought that history had progressed in an evolutionary fashion up to significant turning points that made possible the Nazi rise to power and the Holocaust (as well as the atomic bomb). And so, his voice (like that of Whitehead) was not the dominant voice in conversations regarding evolutionary theories of modernity. One poignant example from Benjamin's writing comes in Thesis VIII of his "Theses on the Philosophy of History," in which he writes:

The tradition of the oppressed teaches us that the "state of emergency" in which we live is not the exception but the rule. We must attain to a conception of history that is in keeping with this insight. Then we shall clearly realize that it is our task to bring about a real state of emergency, and this will improve our position in the struggle against Fascism.

\footnotetext{
${ }^{41}$ Ibid., 9.

${ }^{42}$ Ibid., 109.
} 
One reason why Fascism has a chance is that in the name of progress its opponents treat it as a historical norm. ${ }^{43}$

Here we see Benjamin's insistence that the revolutionary irruption within history be brought about by human agency, as well as his concern with notions of inevitable progress. Benjamin criticized any sovereign that promoted instantiations of power as foregone conclusions of a certain progression of history, or as historical norms.

Benjamin's rejection of linear evolutionary progressions in history aligns well with Whitehead's own non-linear understanding of time. In both, the present, while certainly conditioned by the past, is not entirely determined by the past-either immediate past or longerterm trajectories or patterns emerging from the past. The present and future are equally open to the possibility for instantiations of novel events and to the potentiality of the future. While in Whitehead's metaphysics novelty occurs via the principle of creativity and a concrescing occasion's awareness that it has a future, for Benjamin these novel events are possible because of the unpredictability of political action. No one knows where or when revolutionary events might occur; instead, they come as a surprise and interrupt the historical progression, which for Benjamin may well be devolution toward catastrophe. Löwy again writes, "the worst is not unavoidable. History remains open; it has other - revolutionary, emancipatory and/or utopianpossibilities to it."44

In theses XIII and XIV Benjamin articulates a difference between empty time and jetztzeit (or now-time), the former as part of a homogenous picture of history - the sort that seeks inevitable progression toward ever-greater things - and the later as part of a heterogeneous vision of history-history as an uneven development in which some things progress and others decline

\footnotetext{
${ }^{43}$ Benjamin, "Theses on the Philosophy of History," 257. The state of emergency here undoubtedly refers to Carl Schmitt's political theory in which a sovereign must from time to time announce a state of exception in order to take the reigns, so to speak, and steer society away from catastrophe.

${ }^{44}$ Löwy, 111.
} 
from time to time. Jetztzeit for Benjamin means a present-ness in which unpredictable events occur, events that irrupt and rupture the historical continuum with their revolutionary or emancipatory power. "The aim," writes Löwy, "is to explode the continuum of history with the aid of a conception of historical time that perceives it as 'full', as charged with 'present', explosive, subversive moments. ${ }^{24}$ Jetztzeit draws from experiences in the past and from the possibility of the as yet unwritten future in order to create a novel event in which the historical trajectory might be altered in such a way that structures of oppression collapse (even if only temporarily) in order to liberate the downtrodden from their subjugation. Again, the formation of novel occasions resonates with Whitehead's metaphysics in that the revolutionary irruption in the Jetztzeit intersects both past and future as it comes together in the "now".

Placing theology into the service of historical materialism involves peering through the obliquely angled camera at damaged life by means of critical self-reflection (as described by Adorno) and the weak Messianic power (described by Benjamin). Taking these two notions in tandem and looking again through the obliquely angled camera, the apparatus through which the redeemed views damaged life, thus requires something of the person who assumes the perspective of the redeemed. If the one who stands in such a position can now be understood as one who has both survived oppressive conditions and continues to look toward the revolutionary task of overturning such conditions, then inverse theology today still requires action—-the task is to change material conditions, not escape them. Benjamin's notion of remembrance as redemption and his conception of Jeztzeit lead toward an inverse theology that critically reflects upon and remembers the harmful past, the reality of material existence.

\footnotetext{
${ }^{45}$ Ibid., 88.
} 


\section{Remembrance of Damaged Life}

Ultimately, Volf's desire to overcome suffering by means of Christ's death and resurrection results in a solution that I cannot accept — a solution that seeks to overcome the past through redemption by means of God's transcendence. Rather than moving too quickly to resurrection and eschatology, which I do not deny, I want to remain in the suffering of material life a little longer. Let us not be masochists, but let us learn from the writings of Benjamin and realize the importance of this-worldly remembrance. Remembrance $i$ s redemption, and it is a type of redemption that does not abandon or efface the suffering of material life, but retains a focus on damaged life, refusing to engage in exercises that end solely in reflection and meditation on the transcendent. Ultimately, I find Benjamin's version of inverse theology and remembrance as redemption to be much more compelling than Volf's theology of remembrance precisely because of Benjamin's (and Adorno’s) commitment to material reality. My own theology of remembrance does not deny transcendence, yet I refuse to focus on transcendence to the detriment or abandonment of the material world and the ongoing suffering thereof. Metz likewise critiques theologies that engage in exercises to explain the "suffering God, suffering between God and God, and suffering in God," writing that all of these "have been discussed with great seriousness and theological thoroughness - from Karl Barth to Eberhard Jüngel, from Dietrich Bonhoeffer to Jürgen Moltmann...Is there not in them still too much of a speculative, almost gnostic reconciliation with God behind the back of the human history of suffering?"46 Metz clearly communicates how seeking reconciliation with God always takes place behind the backs of those who have suffered throughout human history, thus resulting in a reconciliation that cannot face or cannot be repeated in the face of those who have survived or been overcome

\footnotetext{
${ }^{46}$ Metz, "Theology as Theodicy?" 69.
} 
by oppression and suffering. As a result, Benjamin's notion that remembering the suffering allows us to remain in solidarity with the victims provides a theological vision that does nothing behind the backs of the victims. After all, as Whitehead terms it, "Religion is world-loyalty." Moreover, this world-loyalty for Whitehead ensures that God remember the past, all events of the world, by taking each moment of the past into God's self, exhibiting God not as divorced from the actual, material world, but as inextricably and intimately tied to the world.

While Volf's conclusion may not fit with this theology of remembrance, he does offer post-Shoah theologies two helpful thoughts. First, he teaches us that we must remember rightly. One means of remembering rightly is to remember "truthfully," which does not mean that one should engage in a detailed recounting of past events, but rather that one should guard against either aggrandized or depleted accounts of the past. Second, Volf writes that "what we remember often deeply affects what we $d o . " 48$ Therefore, just as in Whitehead's metaphysics, memory of the past has a real bearing upon the present and future of our own becoming. This second statement also lends more force to the task of remembering rightly, since failing to remember or remembering only selectively likewise impacts our future actions in the world. The tendency in the Western world to memorialize past events in monuments and museums certainly has its place. Yet, James Young deconstructs this Western desire to memorialize in order to demonstrate what Volf attempts to avoid with his theology. Young shows that memorials often provide a site for remembrance such that the burden of remembering need no longer be felt by the people who visit the memorial. He also critiques memorials that demonstrate a mastery of the past by aggrandizing the past into some triumphant monolith (literally). Construction of memorials such as these demonstrate our desire to leave the past inside of the monument so that

\footnotetext{
${ }^{47}$ Whitehead, "Religion in the Making," 60.

${ }^{48}$ Volf, 68.
} 
we no longer feel the need to remember on our own, thereby creating real possibilities in which we might remember wrongly or cease to remember at all. ${ }^{49}$

In order to guard against both the effacement of memory and the desire to remember selectively, what I suggest becomes a part of Christian theology is a norm of remembrance-an injunction to remember the deleterious past without seeking to integrate all past events into an overarching narrative and without attempting to endow past events with positive meaning. By returning to Whitehead at this point, we gain a metaphysical since in which this can in fact be the case. As discussed in chapter six, for Whitehead God takes the past - the entirety of the past, both joyful and baleful — into God's self not in order to redeem the past through appeals to transcendence, but in order to retain even those most painful and tragic aspects of the past. Only after prehending or recognizing the past for what it is does God cast a vision for a future in which those harmful components might not be repeated. Obviously we must say that they "might not be repeated," because God's role is only one part of the process of remembering, of mastering the present through conscious decisions to evaluate, critique, and retain the past. Humanity equally bears the responsibility of remembering and of choosing better alternatives for the future in each subsequent moment. The antitheses Whitehead enumerates between God and the world display the interplay in responsibility for the world as well as the sense in which religion is "world loyalty":

It is as true to say that the World is immanent in God, as that God is immanent in the World.

It is as true to say that God transcends the World, as that the World transcends God. It is as true to say that God creates the World, as that the World creates God. ${ }^{50}$

As contrasted opposites, Whitehead ensures that God and the world remain loyal to each other. God and the world require each other in order to create and affirm each other in the act of

\footnotetext{
${ }^{49}$ Young, The Texture of Memory, 5.

${ }^{50}$ Whitehead, Process and Reality, 348.
} 
remaining loyal to actuality. While he does not eschew a sense of transcendence, he also refutes those theologies that maintain pure transcendence - theologies of God as the unmoved mover, or theologies of God as Absolute Spirit, divorced from the world and beyond relation with the world. Present in these contrasted opposites, consequently, is also the idea that the world bears equal responsibility for both God and the world. Actions in the world have a real and lasting impact on God, as well as on the world in which such actions are conducted. Therefore, if the world forgets the tragic aspects of the past, the deleterious events of the Holocaust, then the past has been mastered in the sense that the past no longer offers ethical impulses for the present and future. And if this is the case, then mastery of the present recedes further into the horizon.

Significantly, the understanding developed in chapter five that singular events might be universalized also has a particular bearing upon this norm of remembrance. If singular events universalize themselves and ripple through time from the past into the present and future, then universalization ensures that such singular events will be remembered both now and in the future. Whitehead crucially provides a very real sense, then, in which this norm of remembrance is not only a theologically needed norm, but also a metaphysical possibility within the metaphysical system ascribed to in this theology of remembrance.

Additionally, Whitehead writes in his chapter on "The New Reformation" in Adventures of Ideas that "The appeal to history gains its importance by reason of [the] complex character of human experience. Metaphysics and theology alike require it." ${ }^{, 51}$ Prior to this statement, Whitehead discusses the complexity of memory, suggesting that we are not our past. We are different from it, yet also bound to it in that our remembrance of the past enables our actions and choices in the present, be they good or destructive. As a result, theology requires history insofar as theology must understand the past out of which the present emerges and out of which

\footnotetext{
${ }^{51}$ Whitehead, Science and the Modern World, 164.
} 
theological (and metaphysical) statements take shape. Religion as world-loyalty requires remembrance if it is to be able to formulate theological statements (however tentative) that remain tenable after the events of Auschwitz. And the requirement of ensuring that theological statements are tenable could be said, I suggest, to be a vital part of mastering the present.

Indeed, the process of coming to terms with the past should become, as Voegelin reminds us, a process in which we come to terms with the present. We must continue to work upon the present to guard against an empty and cold forgetting. And so I return here to the concrete events that make this project necessary. Such forgetfulness (coupled with the drive to reconstruct and re-write the events of history) has more recently been exemplified in the German reception of Daniel Goldhagen's Hitler's Willing Executioners and its connection to the German Historikerstreit of the late 1980 s and early 2000 s as well as in the Iranian government's virulent attempts to prove the Holocaust a fiction. These events serve as an injunction to remember the past and to work more forcefully upon the present. Going into a bit more detail regarding the enthusiastic (almost rock-star-like) reception of Daniel Goldhagen demonstrates the deep-seated desire to formulate excuses for the past, to efface the past through the type of alibi procedures that Voegelin criticized. Goldhagen argues in his book, published in 1996, that anti-Semitism "more or less governed the ideational life of civil society" in Germany prior to the rise of National Socialism. ${ }^{52}$ Therefore, he contends, once Hitler was elected to power the move to rampant and institutionalized anti-Semitism was an easy and natural progression, since Hitler and the German populace were "of one mind." ${ }^{53}$ His thesis is that anti-Semitism does not disappear and later reappear, but that it is always present and only manifests itself to varying degrees at various times. However, after 1945 — after the defeat of Nazi Germany — he suggests

\footnotetext{
${ }^{52}$ Goldhagen, Hitler's Willing Executioners, 106. Quoted in Christopher R. Browning, Ordinary Men: Reserve Police Battalion 101 and the Final Solution in Poland (New York: Harper Perennial, 1998), 192-193.

${ }^{53}$ Goldhagen, Hitler's Willing Executioners, 399. Quoted in Browning, Ordinary Men, 193.
} 
that German anti-Semitism suddenly disappeared. The nation that had historically been so overcome with anti-Semitism, according to Goldhagen, now finds itself free of anti-Semitism. Christopher Browning summarizes Goldhagen's argument on this point: "Given reeducation, a change in public conversation, a law banning anti-Semitic expression, and the lack of institutional reinforcement, a German culture dominated by anti-Semitism for centuries was suddenly transformed. Now, we are told, the Germans are just like us." ${ }^{54}$ Goldhagen's thesis is problematic for numerous reasons: first, one can find little evidence to support his view that most Germans prior to 1933 were subconsciously obsessed with anti-Semitism; and second, it seems equally ridiculous to think that an entire population could quickly and suddenly change such long-held and deep-seated views, even if reeducation and public policy did play a role. What the German public applauded Goldhagen for was his contention that "today's ordinary Germans have little in common with their relentless forefathers. ${ }^{, 55}$ The fanatic reception of Goldhagen in Germany demonstrates that the desire to provide excuses or alibis for the horrendous past remains ever-present, as Voegelin points out. This further elicits the view that the present has not in fact been mastered, since one must still convince oneself that he/she is nothing like those who committed or were complicit in the atrocities of the past.

Additionally, various stirrings of Holocaust denial continue to reaffirm the necessity of a theology of remembrance, even nearly 70 years after the Holocaust. Most notably (and famously) in recent years, Mahmoud Ahmadinejad, President of Iran, stood before the United Nations assembly in September of 2009 and publically called the Holocaust a lie. Iran has also organized and hosted conferences aimed at determining whether or not the Holocaust actually occurred, such as one held in late 2006. This blatant anti-Semitism has become a part of the nation's

\footnotetext{
${ }^{54}$ Christopher R. Browning, Ordinary Men: Reserve Police Battalion 101 and the Final Solution in Poland (New York: Harper Perennial, 1998), 193.

${ }^{55}$ Kansteiner, "Winning the Memory Battle," 131.
} 
public policy, and anti-Semitic rhetoric, including Holocaust denial, aids the country's leaders in building support among its own citizenry of campaigns against Israel (whether rhetorical or military). On the day following Ahmadinejad's address to the UN, Israeli Prime Minister Benjamin Netanyahu spoke before the assembly denouncing those who had stayed and given Ahmadinejad an audience. For Netanyahu, even the act of listening to such overtly anti-Semitic and potentially violent rhetoric demonstrates complicity with the anti-Semitic views and moral degradation; and the fact that some did stay to hear Ahmadinejad's address bespeaks the fact that the past has not been overcome. Such events provide the ethical impetus for constructing a theological norm of remembrance and a means of mastering the present through critical selfreflection and remembrance of the horrendous past.

The theological process of mastering the present arises through a commitment to remember, redeem and alter (for the better) damaged, human life. Mastering the present does not mean that all suffering ends or that the world somehow exhibits utopian characteristics, since such things would point only to an immanentization of the eschaton and not a mastery of the present. Moreover, the remembrance as redemption that Benjamin thinks will result in revolutionary bursts equally refuses to immanentize the eschaton insofar as Jetztzeit induces moments of revolutionary fervor and not utopian fervor. The presentness of the past and future cannot solve the problem of Vergangenheitsbewältigung by introducing some extra-worldly time in which the past no longer matters (particularly since, through Whitehead, we have seen that this is not metaphysically possible); quite to the contrary, Benjamin's Jetztzeit ensures that the possibilities inherent in the future achieve their realization in the presentness of material reality only by remembering the past and addressing the suffering of the past. Inasmuch as this is a Christian theology, my desire is not to take Benjamin hostage for the Christians, but to learn 
from Benjamin in order to more appropriately theologize as a Christian. One way of doing so might be to articulate an understanding of Jesus as offering similar patterns of remembrance and presentness that maintain their focus on damaged life. I do so not in order to usurp Benjamin's thought and suggest that it's ultimate formulation ends in Christianity (as Zizek perhaps has done), but to articulate a Christian theology that desires to live alongside Judaism, allowing each to retain its own particularities. Through the Gospels Jesus teaches Christians the importance of remembering, and he inaugurates a sense of presentness that coalesces the past—both the disruptive and creative past - with the future that comes to us from God. Jesus never abandoned the world, but demanded remembrance of the world as the only means of realizing the basileia within material reality. The presentness that he enacted provided the necessary disruptions in a world dominated by the oppressive conditions of an empire in order for revolutionary actions to take place within the temporal realm. To be sure, such presentness did not introduce utopian realities, since empires continued to dominate the landscape of the Western and Near-Eastern world of antiquity. Moreover, these same empires later became wed to Christianity itself as an act that might hint at an immanentization of the eschaton. Nevertheless, Jesus' own vision of solidarity with the suffering of damaged life does not encourage escape from the material world, but articulates a hope for better futures within materiality. Christians must remember, alongside Jesus, in the hope against hope that conditions engendering such suffering might be diminished as the world unfolds its future moments. As Whitehead poignantly remarks, "So long as the Galilean images are but the dreams of an unrealized world, so long they must spread the infection of an uneasy spirit." ${ }^{, 56}$ Our own failure to remember, our failure to sense the presentness of Jesus within material reality, results in the continuation of patterns of destruction - the very same patterns that lead in the past to virulent anti-Judaism and anti-

\footnotetext{
${ }^{56}$ Whitehead, Adventures of Ideas, 17.
} 
Semitism within Christian theologies. Additionally, attempting to realize the Galilean images requires an approach that may most helpfully be termed an inverse theology insofar as it views the world in all of its decay, excrement, and putrefaction while simultaneously recognizing that possibilities exist for this world to be positively altered, transformed into an alternative reality.

Contemporary Christian theologian and critical theorist Peter Rollins offers a Christology that seems to me very much in line with Adorno and Benjamin's notion of inverse theology; furthermore, it provides a significant rebuttal to Volf's insistence that the resurrection ultimately redeems suffering by endowing the deleterious past with positive meaning. Rollins in various ways demonstrates a robust materialist worldview, one that alters his conception of the Crucifixion and Resurrection. ${ }^{57}$ He summarizes his particular theology of the Resurrection by describing it as "a mode of living that embraces the lived experience of doubt, complexity, and unknowing, affirms life, and accepts our responsibility in transforming the world. ${ }^{, 58}$ Quite opposed to viewing the Resurrection as an escapist solution to the problems of the material world, Rollins sees it as an affirmation of the world and of all the putrefaction that this world entails. In the Resurrection God does not abandon this world, but returns to the world in order to participate in damaged life: "in the Resurrection, we discover that God remains, dwelling in our very midst through the embrace of life." ${ }^{59}$ Describing the mode of Christianity that supports such a view of the Resurrection, he writes: "For the believer who passes through the Christian experience, God is no longer related to as an object out there. Rather, God is affirmed only through a passionate participation in life itself. ${ }^{60}$ Hence, there is no recourse for Christians to a transcendent beyond, but rather Christians find within the theology of the Resurrection a fervent affirmation of God's

\footnotetext{
${ }^{57}$ Rollins capitalizes Crucifixion and Resurrection (most likely because he views them as paradigmatic events), and so in the remainder of this dissertation I will adopt his capitalization patterns.

${ }^{58}$ Peter Rollins, Insurrection (New York: Howard Books, 2011), 138.

${ }^{59}$ Ibid., 160.

${ }^{60}$ Ibid., 127. Emphasis in original.
} 
solidarity with the reality of this world and all that this reality entails. As a result, "This deeply Christological approach fundamentally critiques the pagan idea that there is some overarching Destiny within which the seeming chaos of life finds its purpose." ${ }^{\prime 61}$ Contra this pagan/gnostic (and perhaps Christian) notion of destiny, Rollins inverts the creative agency by suggesting that "destiny no longer refers to some predetermined reality that history conforms to, but rather comes into being through our direct participation in the transformation of the world. In short, we participate in the creation of the eternal itself." ${ }^{\prime 62}$ Here Rollins bridges notions of inverse theology coming from Adorno and Benjamin with the type of theistic vision found in Whitehead's speculative philosophy by supporting the idea that humans are endowed with a form of agency in the world that in fact participates in forming or creating the transcendent/immanent God. Equally important, humanity also finds itself endowed with the agency to participate in transforming material reality.

As Rollins demonstrates, we need not disavow any and every appeal to transcendence, but must realize that transcendence cannot be grasped as an escapist mechanism in order to relieve oneself from responsibility to this world or as a solution to the problem of coming to terms with the past via an extra-worldly reconciliation. Instead, following both Whitehead and Voegelin, human participation in the transcendent does not remove one from material reality and does not expunge one of one's duty to remember (and thus live in solidarity with the suffering of damaged life). Rather, this participation does, as Voegelin writes, place us under judgment in the immanent present, meaning that we must affirm the reality in which we live by adjudicating "how [one] acts and how others act" $" 63$ in recognition of the sense of being under judgment. Like

\footnotetext{
${ }^{61}$ Ibid., 132-133. As a side note, I believe that Rollins actually means "Gnostic" rather than "pagan," since much of contemporary paganism is deeply rooted in the earth and in lived or embodied relationality and experience.

${ }^{62}$ Ibid., 133. Emphasis in original.

${ }^{63}$ Voegelin, Hitler and the Germans 71.
} 
Rollins, I suggest that this appeal to transcendence as a means of grounding the ethical dimension of a materialist Christianity does not provide a circumvention of material reality, but rather weds us more intimately to the world we inhabit; and this is where I see Whitehead as most helpfully mediating the positions of Adorno and Voegelin with regard to transcendence. Their divergent views were outline in the previous chapter, but only now can we fully explicate how they are held together via Whitehead's dipolar God. Like Adorno (and Benjamin), as I have demonstrated already, Whitehead refuses to allow theology to abandon the actual world in favor of a notion of God as unmoved mover. Thus, his conception of God remains the chief exemplification of the metaphysical scheme, rather than an exception to all of the rules. This God is intimately connected to the actual world, the material reality in which humanity experiences joy and suffering, and so can be said to be immanent in the world, just as the world is immanent in God by means of God's consequent nature. However, God also transcends the world in that the primordial nature remains the eternal and non-temporal locus of potentiatliythe origination of all future possibility, regardless of what transpires in actuality. Therefore, Whitehead indicates that both divine immanence and divine transcendence ultimately prove necessary for responding to the deleterious past. In no sense can the world be abandoned in favor of something beyond the world, yet at the same time, the notion of divine transcendence grounds all future possibilities and, therefore, grounds the possibilities by which we might master the present as a presence under God, as Voegelin invaluably suggests we must. Moreover, as hinted above, this transcendence-whether in Whitehead's notion of the primordial nature or Voegelin's grounding of the individual under an ethical mandate - remains something for material reality. It does not provide us with an escape from the conditions in which we live and the conditions to which we must continually orient ourselves. Conversely, and indispensably, it 
allows us to peer through the lens of the obliquely angled camera from the perspective of the redeemed at the suffering of damaged life, and in so doing we recognize the need to remember and, thereby, to live in solidarity with the suffering of the past. Though we cannot alleviate past suffering through this sense of solidarity in remembrance, we can work toward ensuring that the same or similar atrocities are not committed. The angel of history cannot turn from the pile of wreckage, and neither can we abandon the suffering of the past in favor of a hoped for reconciliation in the world to come. The past is not overcome, nor can it be; though through the "world loyalty" of a materialist Christian theology of remembrance, we can participate in the transcendence in order to work toward mastering the present. 


\section{Bibliography}

Adorno, Theodor W., et al. The Authoritarian Personality. New York: W.W. Norton \& Company, Inc., 1969.

Adorno, Theodor W. "Education After Auschwitz." In Can One Live After Auschwitz?: A Philosophical Reader. Edited by Rolf Tiedemann and translated by Rodney Livingstone and others. Stanford, CA: Stanford University Press, 2003.

Adorno, Theodor W. "The Meaning of Working Through the Past." In Can One Live After Auschwitz?: A Philosophical Reader. Edited by Rolf Tiedemann and translated by Rodney Livingstone and others. Stanford, CA: Stanford University Press, 2003.

Adorno, Theodor W. Metaphysics: Concept and Problems. Edited by Rolf Tiedemann and translated by Edmund Jephcott. Stanford, CA: Standford University Press, 2000.

Adorno, Theodor W. Negative Dialectics. Translated by E. B. Ashton. New York: Continuum, 2007.

Adorno, Theodor W. "Reason and Revelation." In Critical Models: Interventions and Catchwords. Translated by Henry W. Pickford. New York: Columbia University Press, 1998.

Adorno, Theodor W. "Was bedeutet: Aufarbeitung der Vergangenheit." In Ob nach Auschwitz noch sich leben lasse: Ein philosophisches Lesebuch. Edited by Rolf Tiedemann. Frankfurt am Main: Suhrkamp, 1997.

Adorno, Theodor W. and Walter Benjamin. The Complete Correspondence: 1928-1940. Edited by Henri Lonitz. Translated by Nicholas Walker. Cambridge, MA: Harvard University Press, 1999.

Arendt, Hannah. Eichmann in Jerusalem: A Report on the Banality of Evil. New York: Penguin Classics, 2006.

Bauman, Zygmut. Modernity and the Holocaust. Ithaca, NY: Cornel University Press, 2000.

Benjamin, Walter. Origin of German Tragic Drama. Translated by John Osborne. New York: Verso Books, 1998.

Benjamin, Walter. "Theses on the Philosophy of History." In Illuminations: Essays and Reflections. Edited by Hannah Arendt. New York: Schocken Books, 1969.

Benjamin, Walter. "Theologico-Political Fragment." In Reflections: Essays, Aphorisms, Autobiographical Writings. Edited by Peter Demetz. New York: Schocken Books, 1978. 
Berkovits, Eliezer. Faith After the Holocaust. New York: KTAV Publishing House, 1973.

Braeckman, Antoon. "Whitehead and German Idealism: A Poetic Heritage." Process Studies 14, no. 4 (Winter, 1985): 265-286.

Braiterman, Zachary. (God) After Auschwitz: Tradition and Change in Post-Holocaust Jewish Thought. Princeton, NJ: Princeton University Press, 1998.

Brittain, Christopher Craig. Adorno and Theology. New York: T \& T Clark, 2010.

Browning, Christopher R. Ordinary Men: Reserve Police Battalion 101 and the Final Solution in Poland. New York: Harper Perennial, 1998.

Clemens, Detlev. "Eric Voegelin's 'Hitler and the Germans' Lectures in the Context of the Germans' Treatment of Their Nazi Past." In Eric Voegelin, "Hitler and the Germans." In The Collected Works of Eric Voegelin. Translated and edited by Detlev Clemens and Brendan Pucell. Columbia, MO: University of Missouri Press, 1999.

Conlin, Joseph R. ed. The Morrow Book of Quotations in American History. New York: McMorrow, 1984.

Eriksen, Robert P. and Susannah Heschel, editors. Betrayal: German Churches and the Holocaust. Minneapolis: Fortress Press, 1999.

Faber, Roland. “The Divine Manifold.” 2012.

Faber, Roland. God as Poet of the World: Exploring Process Theologies. Translated by Douglas W. Stott. Louisville: Westminster John Knox Press, 2008.

Faber, Roland. "On the Unique Origin of Revelation, Religious Intuition, and Theology" in Process Studies 28, no. 3-4 (2002): 195-211.

Fackenheim, Emil. God's Presence in History: Jewish Affirmations and Philosophical Reflections. Northvale, NJ: Jason Aronson Inc., 1997.

Fackenheim, Emil. To Mend the World: Foundations of Post-Holocaust Jewish Thought. Bloomington, IN: Indiana University Press, 1982.

Flannery, Edward. The Anguish of the Jews: Twenty-Three Centuries of Anti-Semitism. New York: Paulist Press, 1985.

Faulkner, William. Requiem for a Nun. New York: Random House, 1951.

Ford, Lewis. Transforming Process Theism. Albany, NY: State University of New York Press, 2000. 
Goldhagen, Daniel. Hitler's Willing Executioners: Ordinary Germans and the Holocaust. New York: Alfred A. Knopf, Inc., 1996.

Habermas, Jürgen. “Can We Learn from History?” In A Berlin Republic: Writings on Germany. Translated by Steven Rendall. Lincoln, NE: University of Nebraska Press, 1997.

Habermas, Jürgen. "What Does 'Working Off the Past' Mean Today?” In A Berlin Republic: Writings on Germany. Translated by Steven Rendall. Lincoln, NE: University of Nebraska Press, 1997.

Halewood, Michael. A. N. Whitehead and Social Theory: Tracing a Culture of Thought. New York: Anthem Press, 2011.

Hartmann, Klaus. "Types of Explanation in Hegel and Whitehead." In Hegel and Whitehead: Contemporary Perspectives on Systematic Philosophy. Edited by George R. Lucas, Jr. Albany, NY: State University of New York Press, 1986.

Hegel, G.W.F. Philosophy of Right. Translated by T.M. Knox. New York: Oxford University Press, 1967.

Helmer, Christine. "Introduction." In Schleiermacher and Whitehead: Open Systems in Dialogue. Edited by Christine Helmer, et al. New York: Walter de Gruyter, 2004.

Horkheimer, Max and Theodore Adorno. Dialectic of Enlightenment: Philosophical Fragments. Edited by Gunzelin Schmid Noerr. Translated by Edmund Jephcott. Standford: Standford University Press, 2002.

Horowitz, Gad. "Global Pardon: Pax Romana, Pax Americana, and Kol Nidre." http://bad.server.org/issues/2001/58/horowitz.html.

Hosinski, Thomas E. Stubborn Fact and Creative Advance: An Introduction to the Metaphysics of Alfred North Whitehead. New York: Rowman \& Littlefield Publishers, Inc., 1993.

Kansteiner, Wulf. "Losing the War, Winning the Memory Battle: The Legacy of Nazism, World War II, and the Holocaust in the Federal Republic of Germany." In The Politics of Memory in Postwar Europe. Edited by Richard Ned Lebow, et al. Durham, NC: Duke University Press, 2006.

Klee, Ernst. Persilscheine und falsche Pässe: wie die Kirchen den Nazis halfen. Frankfurt am Main: Fischer Taschenbuch Verlag, 1991.

Kline, George L. "Concept and Concrescence: An Essay in Hegelian-Whiteheadian Ontology." In Hegel and Whitehead: Contemporary Perspectives on Systematic Philosophy. Edited by George R. Lucas, Jr. Albany, NY: State University of New York Press, 1986. 
Kramer, Jane. The Politics of Memory: Looking for Germany in the New Germany. New York: Random House, 1996.

Kraus, Elizabeth. The Metaphysics of Experience: A Companion to Whitehead's Process and Reality. New York: Fordham University Press, 1998.

Kunert, Günter. "Fahrt mit der S-Bahn." In Immer Wieder am Anfang: Erzählungen und kleine Prosa. Reclam, Philipp, jun. GmbH, Verlag, 1999.

Kunert, Günter. "Gedenken und erinnern.” In Auskunft für den Notfall. München: Carl Hanser Verlag, 2008.

Kunert, Günter. "Geschichte als Gegenstand der Betrachtung." In Auskunft für den Notfall. München: Carl Hanser Verlag, 2008.

Lebow, Richard. "The Memory of Politics in Postwar Europe." In The Politics of Memory in Postwar Europe. Edited by Richard Ned Lebow, Wulf Kansteiner, and Claudio Fogu. Durham, NC: Duke University Press, 2006.

Lebow, Richard Ned, Wulf Kansteiner, and Claudio Fogu, eds. The Politics of Memory in Postwar Europe. Durham, NC: Duke University Press, 2006.

Levinas, Emmanuel. "Useless Suffering." In The Provocation of Levinas: Rethinking the Other. Translated by Richard Cohen. Edited by Robert Bernasconi and David Wood. New York: Routledge, 1988.

Loomer, Bernard. "The Size of God.” In The Size of God: The Theology of Bernard Loomer in Context. Edited by William Dean and Larry E. Axtel. Macon, GA: Mercer University Press, 1987.

Lowe, Victor. Alfred North Whitehead: The Man and His Work. Volume One. Baltimore: Johns Hopkins University Press, 1985.

Lowe, Victor. Alfred North Whitehead: The Man and His Work. Volume Two. Baltimore: Johns Hopkins University Press, 1990.

Löwy, Michael. Fire Alarm: Reading Walter Benjamin's 'On the Concept of History'. Translated by Chris Turner. New York: Verso, 2005.

Maier, Charles. The Unmasterable Past: History, Holocaust, and German National Identity. Cambridge, MA: Harvard University Press, 1998.

Marx, Karl. "Theses on Feuerbach.” In The Portable Karl Marx. Edited by Eugene Kamenka. New York: Penguin Books, 1983. 
Metz, Johann Baptist. "The Church After Auschwitz." In A Passion for God: The MysticalPolitical Dimension of Christianity. Edited and translated by J. Matthew Ashley. New York: Paulist Press, 1998.

Metz, Johann Baptist. “Theology as Theodicy?” In A Passion for God: The Mystical-Political Dimension of Christianity. Edited and translated by J. Matthew Ashley. New York: Paulist Press, 1998.

Moltmann, Jürgen. In the End-The Beginning: The Life of Hope. Translated by Margaret Kohl. Minneapolis: Fortress Press, 2004.

Moltmann, Jürgen. The Coming of God: Christian Eschatology. Minneapolis: Fortress Press, 2004.

Morrissey, Michael P. Consciousness and Transcendence: The Theology of Eric Voegelin. Notre Dame, IN: University of Notre Dame Press, 1994.

Müller-Doohm, Stefan. Adorno: A Biography. Translated by Rodney Livingstone. Malden, MA: Polity Press, 2005.

Nussbaum, Charles. "Logic and the Metaphysics of Hegel and Whitehead.” Process Studies 15, no. 1 (Spring 1986): 32-52.

O'Connor, Brian. Introduction to The Adorno Reader. Edited by Brian O'Connor. Malden, MA: Blackwell Publishers, 2000.

Oppenheimer, Mark. "Miroslav Volf Spans Conflicting Worlds." The Christian Century (January 11, 2003): 18-23.

Parkes, Stuart. Understanding Contemporary Germany. New York: Routledge, 1997.

Picker, Henry. Hitlers Tischgespräche im Führerhauptquartier 1941-1942. Edited by Percy Ernst Schramm. Stuttgart: Seewald Verlag, 1963.

Pinnock, Clark H. Most Moved Mover: A Theology of God's Openness. Grand Rapids, MI: Baker Academic, 2001.

Price, Lucien. The Dialogues of Alfred North Whitehead. Jaffrey, NH: David R. Godine, 2001.

Pritchard, Elizabeth A. "Bilderverbot Meets Body in Theodor W. Adorno's Inverse Theology." Harvard Theological Review 95, no. 3 (2002): 291-318.

Rollins, Peter. Insurrection. New York: Howard Books, 2011.

Rose, Philip. On Whitehead. Belmont, CA: Wadsworth/Thomas Learning, Inc., 2002. 
Rubenstein, Richard. After Auschwitz: Radical Theology and Contemporary Judaism. Indianapolis, IN: Bobbs-Merrill Publishing, 1966.

Suchocki, Marjorie. The Fall to Violence: Original Sin in Relational Theology. New York: Continuum, 1994.

Suchocki, Marjorie. God, Christ, Church: A Practical Guide to Process Theology. New York: Crossroad Publishing Company, 1989.

Stengers, Isabelle. "Whitehead's Account of the Sixth Day." Configurations 13 (2005): 35-55.

Tiedemann, Rolf. Introduction to Can One Live after Auschwitz: A Philosophical Reader. Theodor W. Adorno. Stanford, CA: Stanford University Press, 2003.

Thompson, William M. "Voegelin and the Religious Scholar: an Introduction." In Voegelin and the Theologian: Ten Studies in Interpretation. Edited by John Kirby and William M. Thompson. New York: The Edwin Mellen Press, 1983.

Voegelin, Eric. The Collected Works of Eric Voegelin. Edited by Ellis Sandoz. Baton Rouge, LA: Louisiana State University Press, 1989.

Voegelin, Eric. "Hitler and the Germans." In The Collected Works of Eric Voegelin. Volume 31. Translated and edited by Detlev Clemens and Brendan Purcell. Columbia, MO: University of Missouri Press, 1999.

Voegelin, Eric. Hitler und die Deutschen. Edited by Manfred Henningsen. München: Wilhelm Fink Verlag, 2006.

Voegelin, Eric. The New Science of Politics: An Introduction. Chicago: University of Chicago Press, 1952.

Volf, Miroslav. The End of Memory: Remembering Rightly in a Violent World. Grand Rapids, MI: William B. Eerdmans Publishing Co., 2006.

Volf, Miroslav. Exclusion and Embrace: A Theological Exploration of Identity, Otherness, and Reconciliation. Nashville, TN: Abingdon Press, 1996.

Webb, Eugene. Eric Voegelin: Philosopher of History. Seattle: University of Washington Press, 1981.

Whitehead, Alfred North. Adventures of Ideas. New York: Free Press, 1933.

Whitehead, Alfred North. Process and Reality: Corrected Edition. Edited by Donald W. Sherburne and David Ray Griffin. New York: Free Press, 1978.

Whitehead, Alfred North. Religion in the Making. New York: The Macmillan Company, 1926. 
Whitehead, Alfred North. Science and the Modern World. New York: The Macmillan Company, 1925.

Whitehead, Alfred North. Symbolism, It's Meaning and Effect. New York: The Macmillan Company, 1927.

Williamson, Clark M. A Guest in the House of Israel: Post-Holocaust Church Theology. Louisville, KY: Westminster/John Knox Press, 1993.

Williamson, Clark M. Way of Blessing, Way of Life: A Christian Theology. St. Louis, MO: Chalice Press, 1999.

Young, James. The Texture of Memory: Holocaust Memorials and Meaning. New Haven, CT: Yale University Press, 1993.

Zizek, Slavoj. "Neighbors and Other Monsters." In The Neighbor: Three Inquiries in Political Theology. Chicago: University of Chicago Press, 2005.

Zizek, Slavoj. The Puppet and the Dwarf: The Perverse Core of Christianity. Cambridge, MA: The MIT Press, 2003. 